Valéria Cristiane Oliveira Silva

\title{
ANÁLISE DE CASOS DE IMPLEMENTAÇÃO DE PRODUÇÃO ENXUTA EM EMPRESAS BRASILEIRAS DE MÁQUINAS E IMPLEMENTOS AGRÍCOLAS
}

Dissertação apresentada à Escola de Engenharia de São Carlos da Universidade de São Paulo, como parte dos requisitos para a obtenção do Título de Mestre em Engenharia de Produção.

Orientador: Prof. Associado Antonio Freitas Rentes 
Ficha catalográfica preparada pela Seção de Tratamento da Informação do Serviço de Biblioteca - EESC/USP

S586a Silva, Valéria Cristiane Oliveira empresas brasileiras de máquinas e implementos agrícolas / Valéria Cristiane Oliveira Silva. -- São Carlos, 2006.

Dissertação (Mestrado) -- Escola de Engenharia de São CarlosUniversidade de São Paulo, 2006.

Área: Engenharia de Produção.

Orientador: Prof. Assoc. Antonio Freitas Rentes.

1. Administração da produção. 2. Empresas de máquinas. 3. Implementos agrícolas. I. Titulo. 
FOLHA DE JULGAMENTO

Candidata: Bacharel VALÉRIA CRISTIANE OLIVEIRA SILVA

Dissertação defendida e julgada em 24-03-2006 perante a Comissão Julgadora:
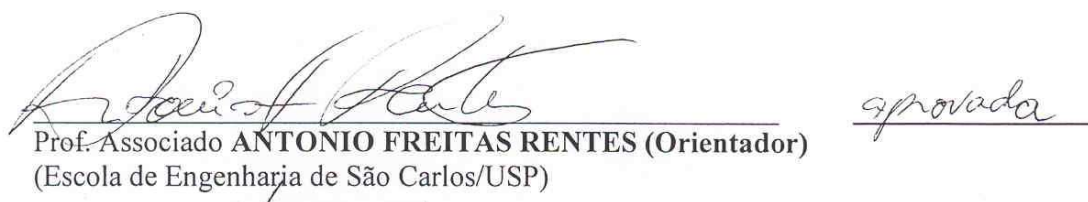

(Escola de Engenharja de São Carlos/USP)

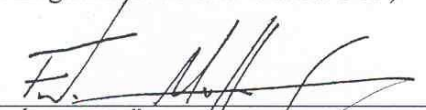

Prof. Dr. FÁBFO MÜLLER GUERRINI

(Escola de Engenharia de São carlos/USP)

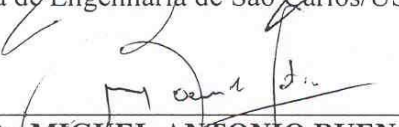

Prof. Dr. MFGUEL AATONIO BUENO DA COSTA

(Universidade Federal de São Carlos/UFSCar )
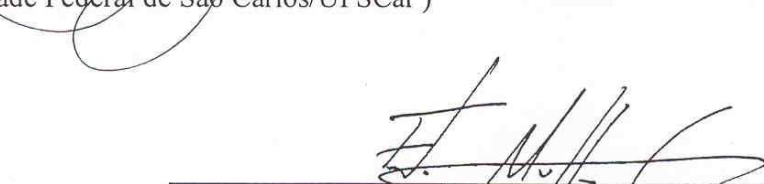

Prof. Dr. FÁBÍO MỐLLER GUERRINI

Coordenador do Programa dé Pós-Graduação em Engenharia de Producáo

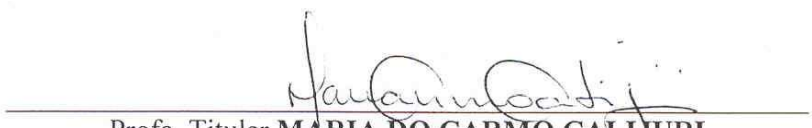

Profa. Titular MARIA DO CARMO CALIJURI

Presidente da Comissão de Pós-Graduação 


\section{AgRADECIMENTOS}

Agradeço especialmente meu orientador e amigo, o Prof. Dr. Antonio Freitas Rentes do Departamento de Engenharia de Produção da Escola de Engenharia de São Carlos EESC/USP, por ter acreditado em minha capacidade e pela sua amizade, apoio, compreensão e dedicação na conclusão desta pesquisa.

À Fundação de Amparo à Pesquisa do Estado de São Paulo - FAPESP - pela concessão da bolsa de mestrado.

Ao Prof. Dr. Fábio Müller Guerrini e o Prof. Dr. Marcel Andreotti Musetti pelas contribuições no exame de qualificação e auxílios prestados durante a elaboração desta pesquisa.

Aos professores e funcionários do Departamento de Engenharia de Produção pela ajuda, colaboração e incentivos dados.

A todos os amigos e colegas da Pós-Graduação e Graduação em Engenharia de Produção e também outros que fiz em São Carlos, pela ajuda, apoio, disposição e amizade.

Aos meus pais e meu irmão pelo amor, compreensão, apoio e principalmente porque acreditam nos meus sonhos e em mim.

E agradeço também a Entidade maior, que me ajuda a todo instante e dá força para superar todas as dificuldades! 


\section{RESUMO}

SILVA, V. C. O. (2006). Análise de casos de implementação de Produção Enxuta em empresas brasileiras de máquinas e implementos agrícolas. Dissertação (Mestrado) Escola de Engenharia de São Carlos, Universidade de São Paulo, São Carlos, 2005.

Atualmente as organizações buscam uma vantagem competitiva para atender melhor seus clientes, através da implementação de processos produtivos que possibilitem esta melhoria. Neste contexto, a Produção Enxuta vem ajudando as empresas brasileiras na busca deste diferencial através de melhoria de processos e produtos. Este trabalho visa mostrar como as empresas nacionais de máquinas e implementos agrícolas estão implementando este conceito, quais práticas estão sendo utilizadas e os resultados obtidos até o momento. Para isso foram pesquisados nove casos de aplicação em empresas do setor, oito no Estado de São Paulo e uma no Estado do Paraná. Foram feitas entrevistas estruturadas através do uso de um questionário projetado para este fim. O trabalho também apresenta uma análise crítica das implementações e faz sugestões para estudos futuros, de modo a auxiliar o setor e fortalecer a disseminação do conceito de Produção Enxuta.

Palavras-chave: produção enxuta; empresas de máquinas e implementos agrícolas 


\section{AbSTRACT}

SILVA, V. C. O. (2006). Analysis of Lean Production implantation in Brazilian agricultural machines and implements companies: cases. M.Sc. Dissertation - Escola de Engenharia de São Carlos, Universidade de São Paulo, São Carlos, 2006.

Organizations are looking nowadays for a competitive advantage to better assist their customers' needs through the implantation of more efficient productive processes. In this context, Lean Production concepts are helping Brazilian companies to discover the differential through the processes and products improvement. This work shows how the agricultural machines and implements companies are implementing this concept, which practices that are being used and the results obtained until the moment. For that, nine cases were researched, at eight companies in the State of São Paulo and one in the State of Paraná, through the use of an especially designed questionnaire. The work also presents a critical analysis of the implantation and makes suggestions for future studies, in way to aid the sector and to fortify the dissemination of the Lean Production concepts.

Keywords: lean production; agricultural machines and implements companies 


\section{LISTA DE FIGURAS}

FIGURA 1 - EXPORTAÇÃO DE MÁQUINAS AGRÍCOLAS. 16

FIGURA 2 - PASSOS DA METODOLOGIA DE PESQUISA ….................................................... 18

Figura 3 - A estrutura do Sistema TOYOTA DE PRODUÇÃO. 25

Figura 4 - FluXo de Produção Tradicional Versus FluXo Unitário ContínuO. . 26

FigURA 5 - BALANCEAMENTO DE OPERAÇÕES TRADICIONAL. 27

Figura 6 - SEPARAÇÃo ENTRE o HoMem e A MÁQuina. 29

FIGURA 7 - LAYOUT EM FORMA DE U. 35

FIGURA 8 - DETERMINAÇÃO DO TEMPO DO SETUP. 37

FIGURA 9 - SISTEMA KANBAN DE 1 CARTÃO 39

FIGURA 10 - SISTEMA KANBAN DE 2 CARTÕES .40

FIGURA 11 - SISTEMA KANBAN DE SINAL 41

Figura 12 - QuAdro de Nivelamento dA CARGA. 43

FIGURA 13 - ETAPAS DO MAPEAMENTO DO FLUXO DE VALOR. .44

FIGURA 14 - ÍCONES UTILIZADOS NO MAPA DO FLUXO DE VALOR. 45

FIGURA 15 - MAPA DO FLUXO DE VALOR. 46 


\section{Lista de Gráficos}

GrÁFico 1 - PrÁticAs DE ProduÇão ENXUTA- IMPORTÂNCIA E APLiCAÇÃo ................ 102

GRÁFICO 2 - APLICAÇÃo DAS PRÁtICAS DE PROdUÇÃo ENXUTA.................................... 103 


\section{LISTA DE QUADROS}

QUADRO 1- VISITAS NAS EMPRESAS. 56

QUADRO 2 - PRIMEIRA PARTE DO ROTEIRO DE ENTREVISTA 59

QUADRO 3 - SEGUNDA PARTE DO ROTEIRO DE ENTREVISTA 60

QUADRO 4 - TERCEIRA PARTE DO ROTEIRO DE ENTREVISTA 61

QUADRO 5 - QUARTA PARTE DO ROTEIRO DE ENTREVISTA 63

QUADRO 6 - QUINTA PARTE DO ROTEIRO DE ENTREVISTA 64

QUADRO 7 - FATORES MOTIVACIONAIS PARA A MUDANÇA 92

QUADRO 8 - APOIO EXTERNO NO PROJETO LEAN. 93

QUADRO 9 - CARACTERÍSTICAS DOS PROJETOS LEAN .94

QUADRO 10 - PRINCIPAIS MEDIDAS TOMADAS 95

QUADRO 11 - PRINCIPAIS PROBLEMAS ENCONTRADOS. 96 


\section{LISTA DE TABELAS}

TABELA 1 - EXPORTADORES AGRÍCOLAS MUNDIAIS 15

TABEla 2 - PRÁticas de PRODUÇÃo ENXUTA 51

TABELA 3 - RESULTADOS OBTIDOS NO PROJETO LEAN - EMPRESA A 67

TABELA 4 - RESULTADOS OBTIDOS NO PROJETO LEAN - EMPRESA B .70

TABELA 5 - RESULTADOS OBTIDOS NO PROJETO LEAN - EMPRESA C 72

TABELA 6 - RESULTADOS OBTIDOS NO PROJETO LEAN - EMPRESA D 75

TABELA 7 - RESULTADOS OBTIDOS NO PROJETO LEAN - EMPRESA E 78

TABELA 8 - RESULTADOS OBTIDOS NO PROJETO LEAN - EMPRESA F. 80

TABELA 9 - RESULTADOS OBTIDOS NO PROJETO LEAN - EMPRESA G 83

TABELA 10 - RESULTADOS OBTIDOS NO PROJETO LEAN - EMPRESA H 86

TABELA 11 - RESULTADOS OBTIDOS NO PROJETO LEAN - EMPRESA I.. 89

TABELA 12 - CARACTERÍSTICAS DAS EMPRESAS ESTUDADAS 90

TABELA 13 - CLASSIFICAÇÃO DAS EMPRESAS PESQUISADAS 91

TABELA 14 - IMPORTÂNCIA DAS PRÁtICAS DE PRODUÇÃo ENXUTA 100

Tabela 15 - AplicaÇão das Práticas de ProduÇão EnXuta. 101

TABEla 16 - PrÁtiCAS DE ProduÇÃo ENXUTA- IMPORTÂNCIA E APLICAÇÃO. 101

TABELA 17 - RESULTADOS OBTIDOS NOS PROJETOS 105

TABELA 18 - ANÁLISE DOS PROJETOS LEAN. 107 


\section{LISTA DE SIGLAS}

ABIMAQ - Associação Brasileira da Indústria de Máquinas e Equipamentos ANFAVEA - Associação Nacional dos Fabricantes Veículos Automotores BNDES - Banco Nacional de Desenvolvimento Social CSMIA - Câmaras Setoriais de Máquinas e Implementos Agrícolas ESALQ - Escola Superior de Agricultura "Luiz de Queiroz" GMMO - Gerenciamento da Mudança e Melhoria Organizacional IFM- Instituto Fábrica do Milênio ISO - International Organization for Standardization JIT - Just in Time MPT - Manutenção Produtiva Total ONU - Organização das Nações Unidas PCP - Planejamento e Controle da Produção PIB - Produto Interno Bruto TPS - Toyota Production System TPT- Toda Parte Toda TQM - Total Quality Management USDA - United States Development Agricultural WIP - Work in Process 


\section{SUMÁRIO}

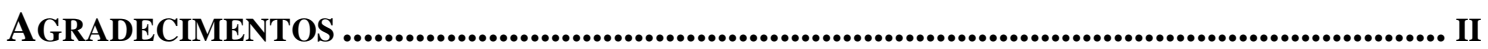

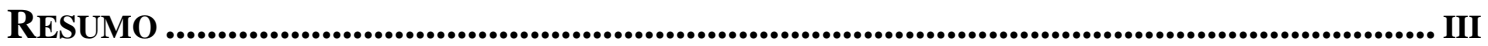

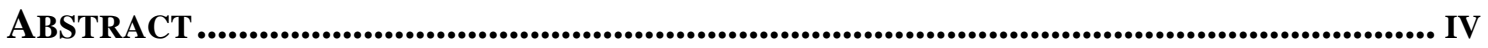

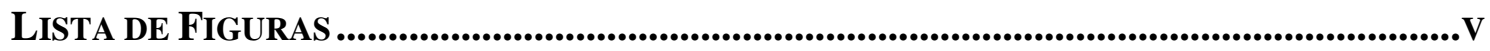

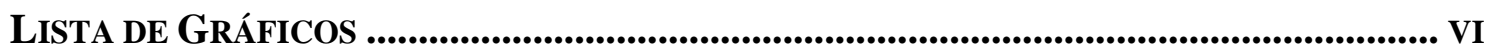

LISTA DE QUADROS ............................................................................................................................. VII

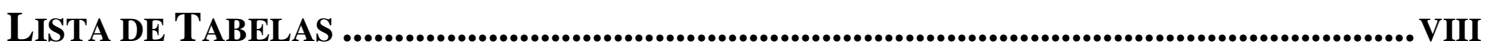

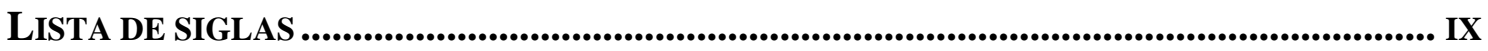

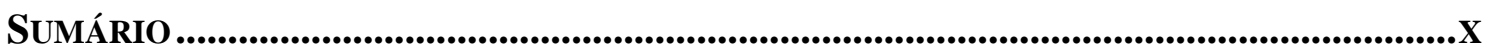

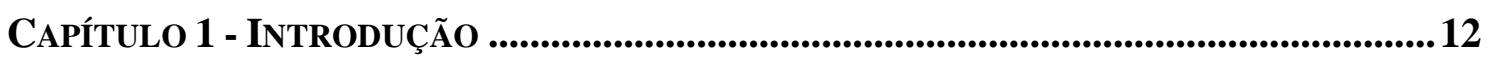

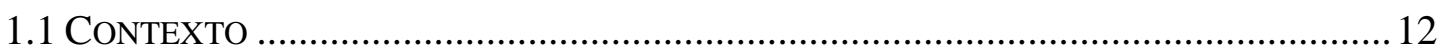

1.2 APRESENTAÇÃO DO PROBLEMA E OBJETIVOS.................................................. 13

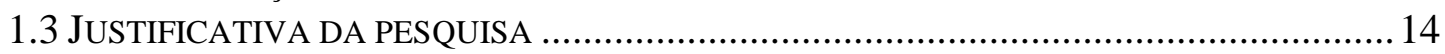

1.4 METODOLOGIA DE PESQUISA E DESENVOLVIMENTO DO TRABALHO........................ 17

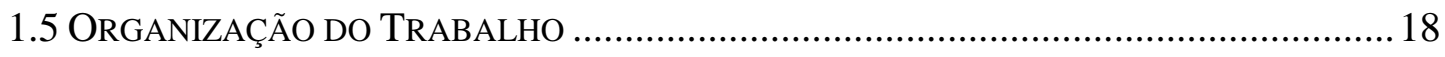

Capítulo 2 - Produção EnXuta ................................................................................. 20

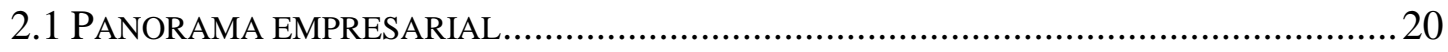

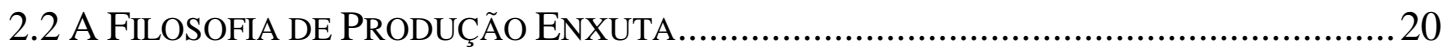

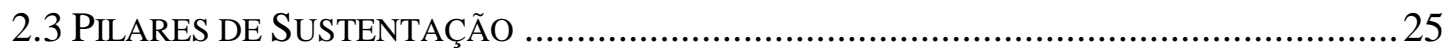

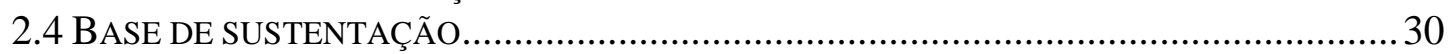

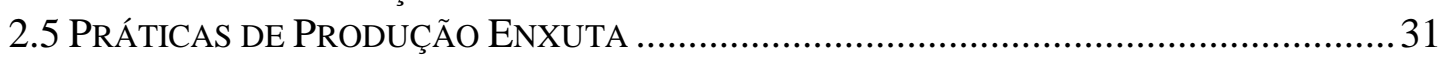

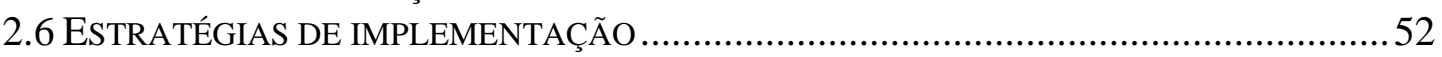

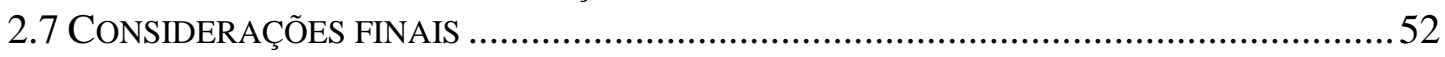

Capítulo 3 - Procedimentos Metodológicos da Pesquisa.................................... 53

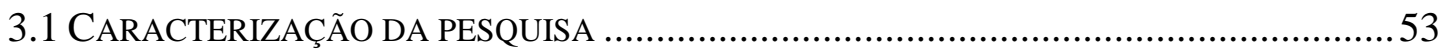

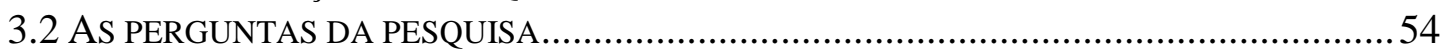

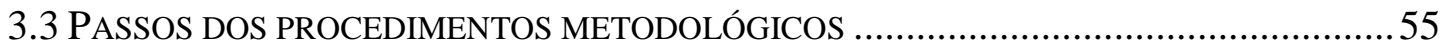

Capítulo 4 - Desenvolvimento e Apresentação dos Estudos de Casos ..........58

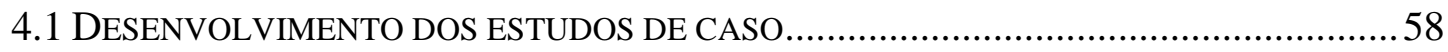

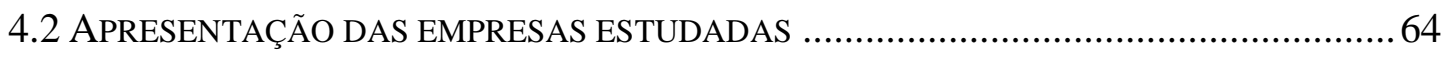

CAPÍTULO 5 - ANÁliSES de DAdOS E RESULTAdOS ................................................90 
5.1 ANÁLISES DAS EMPRESAS E DOS PROJETOS LEAN ................................................ 90

Capítulo 6 - Conclusões e Considerações Finais ............................................108

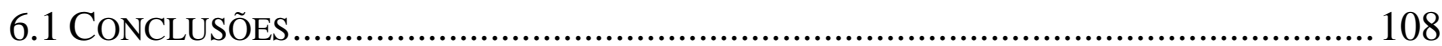

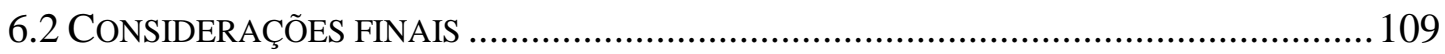

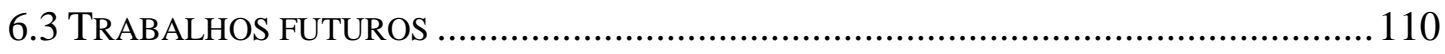

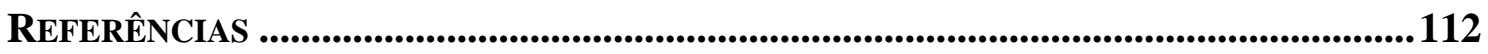

APÊNDICE A - RoTEIRO de ENTREVISTA DA EMPRESA A .......................................118

APÊNDICE B- ROTEIRO DE ENTREVISTA DA EMPRESA B ......................................... 124

APÊNDICE C - ROTEIRO DE ENTREVISTA DA EMPRESA C .........................................130

APÊNDICE D - ROTEIRO DE ENTREVISTA DA EMPRESA D ..........................................136

APÊNDICE E - ROTEIRO DE ENTREVISTA DA EMPRESA E ...................................... 142

APÊNDICE F - ROTEIRO DE ENTREVISTA DA EMPRESA F ............................................. 149

APÊNDICE G - ROTEIRO DE ENTREVISTA DA EMPRESA G..............................................155

APÊNDICE H - ROTEIRO DE ENTREVISTA DA EMPRESA H........................................... 161

APÊNDICE I - ROTEIRO DE ENTREVISTA DA EMPRESA I.........................................167 


\section{CAPítulo 1 - INTRODUÇÃo}

\subsection{Contexto}

A globalização trouxe para as empresas uma possibilidade de expansão de seu mercado consumidor, mas ao mesmo tempo forçou-as a competirem entre si, resultando em uma busca incessante por menores custos e maior qualidade nos produtos e serviços. Essa competitividade acarretou vantagens para o consumidor, já que passou a contar com uma gama maior de produtos/serviços com preços mais atraentes e propiciou para as empresas a busca de modernização e desenvolvimento de conceitos antes não praticados (SLACK et al., 1999).

Em busca de vantagens competitivas, as organizações investiram em processos produtivos que buscassem atender melhor as expectativas de seus clientes.

Neste contexto, a Toyota Motor Company desenvolveu um sistema de produção atualmente conhecido como Produção Enxuta (Lean Production) (WOMACK, JONES e ROOS, 1990), que demonstrou ser um sistema altamente competitivo e que se tornou um padrão.

Segundo Shingo (1996a), a Produção Enxuta engloba ferramentas e técnicas de manufatura, e tem como finalidade a eliminação de desperdícios ao longo do processo produtivo.

Estes desperdícios são classificados em sete categorias: superprodução, espera, transporte excessivo, processos inadequados, inventários desnecessários, movimentação desnecessária e produtos defeituosos (HINES e TAYLOR, 2000).

Este tipo de sistema de produção vem sendo bastante utilizado na indústria automobilística mundial. O mesmo vem ocorrendo na indústria nacional, como exemplo de aplicação deste conceito pode-se citar: a GM, a Daimier Chrysler, a Volvo, a Eaton, dentre outras (LEAN SUMMIT, 2002). 


\subsection{Apresentação do problema e objetivos}

O panorama industrial brasileiro apresenta um avanço nas aplicações da Produção Enxuta, uma vez que as empresas têm buscado cada vez mais alcançar a qualidade, flexibilidade e baixo custo. Como esta abordagem contribui para as melhorias na produção de produtos, eliminação de desperdícios, reduzindo custos ao mesmo tempo em que agrega valor ao produto, acaba trazendo uma vantagem competitiva que permite a estas empresas competir mundialmente.

O setor agroindustrial é um dos setores que vem procurando competir em nível mundial, especificamente o de máquinas e implementos agrícolas. Ele apresenta algumas particularidades que dificultam seu desempenho, pois se caracteriza como um setor onde há grande sazonalidade na demanda de seus produtos e emprega-se a prática da terceirização em muitas empresas.

Segundo Vegro (2004), este setor tem crescido muito nos últimos anos, em razão do bom desempenho do setor agrícola, sendo necessária uma avaliação dos benefícios que o processo produtivo enxuto pode trazer para o mesmo.

O grupo de pesquisa GMMO (Gerenciamento da Mudança e Melhoria Organizacional), do Departamento de Engenharia de Produção da Escola de Engenharia de São Carlos-USP, vem estudando o setor de máquinas e implementos agrícolas, particularmente as contribuições da Produção Enxuta para o setor.

Portanto as questões que nortearam este trabalho e que foram analisadas estão expostas abaixo:

A Produção Enxuta vem sendo conduzida de forma estruturada, ou seja, existem investimentos e metodologia para a implementação deste processo produtivo por parte das empresas de máquinas e implementos agrícolas?

$>$ Quais as práticas de Produção Enxuta que vêm sendo utilizadas por essas empresas?

\section{Quais os resultados obtidos nas empresas estudadas?}

Neste sentido, o objetivo deste trabalho é analisar a implementação de Produção Enxuta em empresas nacionais de máquinas e implementos agrícolas, verificando o nível de penetração deste conceito, bem como os resultados obtidos por elas. 
Assim, este trabalho busca observar e analisar:

$>$ Quais os principais fatores motivadores à implementação de Produção Enxuta;

Quais foram os investimentos necessários à implementação de Produção Enxuta;

Qual a metodologia adotada na implementação de Produção Enxuta;

Quais os principais problemas encontrados nas implantações;

$>$ Quais as mudanças ocorridas nas empresas após a implementação de Produção Enxuta;

Quais as práticas de Produção Enxuta, incluindo ferramentas, conceitos e técnicas utilizadas nas empresas estudadas; e

Quais os resultados obtidos.

\subsection{Justificativa da pesquisa}

Segundo Chade (2002), projeções feitas pela Organização das Nações Unidas (ONU) mostraram que o Brasil tem potencial para se tornar o maior produtor agrícola mundial nos próximos doze anos. Este resultado foi obtido através do Relatório Anual de Commodities, preparado pela conferência da ONU sobre Desenvolvimento e Comércio no ano de 2002, no qual mostrou que o crescimento do setor agrícola brasileiro vem aumentando drasticamente, pois nos últimos dez anos a produção brasileira de grãos cresceu $75 \%$ e as exportações de soja aumentaram quase $100 \%$, com a estimativa de continuar crescendo em média $4 \%$ ao ano até 2010, o que seria quatro vezes mais que a média mundial.

De acordo com este mesmo documento, em 1996, por exemplo, o Brasil produzia 27 milhões de toneladas de soja, menos da metade que os Estados Unidos, e exportava apenas um terço do volume. Em 2001, a produção brasileira continuou sendo $50 \%$ menor que a dos Estados Unidos, mas as exportações em volume dobraram. Isso vem ocorrendo em um cenário onde os produtores americanos recebem 35\% a mais que os brasileiros pelo mesmo volume de soja produzido (CHADE, 2002).

Segundo o United States Development Agricultural (USDA, 2003) que levantou os quinze maiores países exportadores agrícolas globais, o Brasil apareceu em quinto lugar no ano de 2000, perdendo apenas para os Estados Unidos, União Européia, Canadá e Austrália. 
A tabela 1 apresenta os dados referentes aos anos 1990 a 2000, mostrando que nesta década o Brasil superou as exportações de países como a China, Argentina e México.

Tabela 1 - Exportadores agrícolas mundiais

\begin{tabular}{|c|c|c|c|c|c|c|c|}
\hline \multicolumn{8}{|c|}{ Os 15 maiores países exportadores agrícolas } \\
\hline $\begin{array}{l}\text { Exportação } \\
\text { \$ bilhões }\end{array}$ & | 1990 & 1995 & 1996 & 1997 & 1998 & 1999 & 2000 \\
\hline Global & 189,1 & 287,7 & 293,9 & 306,1 & 285,4 & 276,1 & 275,0 \\
\hline Estados Unidos & 40,7 & 58,6 & 62,5 & 58,6 & 53,1 & 50,3 & 52,9 \\
\hline União Européia & 34,2 & 50,6 & 51,5 & 52,3 & 49,5 & 47,4 & 48,1 \\
\hline Canadá & 8,8 & 12,7 & 14,2 & 15,2 & 14,7 & 14,8 & 15,8 \\
\hline Austrália & 11,2 & 12,9 & 15,0 & 15,8 & 13,4 & 14,2 & 15,1 \\
\hline Brasil & 10,0 & 13,5 & 14,7 & 17,2 & 16,0 & 14,1 & 13,6 \\
\hline China & 5,0 & 10,8 & 11,3 & 11,9 & 11,4 & 11,7 & 12,9 \\
\hline Argentina & 5,5 & 10,6 & 12,3 & 12,8 & 12,9 & 11,5 & 11,2 \\
\hline Tailândia & 5,5 & 9,4 & 8,4 & 7,5 & 7,4 & 7,7 & 7,9 \\
\hline México & 3,3 & 5,4 & 4,9 & 5,9 & 6,5 & 6,5 & 6,8 \\
\hline Nova Zelândia & 5,1 & 6,5 & 7,3 & 7,2 & 6,4 & 6,3 & 6,6 \\
\hline União Soviética & 1,0 & 4,5 & 4,2 & 6,6 & 5,2 & 5,1 & 5,9 \\
\hline Malásia & 4,5 & 8,2 & 7,7 & 7,3 & 7,7 & 7,0 & 5,7 \\
\hline Indonésia & 2,9 & 5,9 & 6,4 & 6,9 & 6,0 & 5,9 & 5,5 \\
\hline Índia & 3,5 & 5,3 & 4,3 & 6,4 & 5,9 & 5,2 & 4,1 \\
\hline Turquia & 2,9 & 4,3 & 4,6 & 4,2 & 4,1 & 4,0 & 3,2 \\
\hline
\end{tabular}

Fonte: United States Development Agricultural - USDA

Essa boa movimentação do mercado internacional de soja alavancou a produção brasileira de máquinas agrícolas, que ganhou novos mercados. Com esse desempenho, as máquinas agrícolas representaram 28\% dos US\$ 940,032 milhões exportados no primeiro bimestre de 2004, sendo que no mesmo período do ano anterior, as máquinas agrícolas correspondiam a 19,2\% das exportações automotivas (FUTEMA, 2004).

Em um estudo feito pela Escola Superior de Agricultura "Luiz de Queiroz” (ESALQ- USP, 2003), mostrou que o PIB do agronegocio total, em 2001, atingiu R\$ 344.954,50 milhões, representando 27,06\% do PIB do Brasil. Deste total, o PIB do agronegocio da agricultura, com $\mathrm{R} \$ 238.037,2$ milhões, representou 18,67\% do PIB do Brasil e os investimentos dos fabricantes de máquinas e equipamentos têm superado as expectativas. Em 2002, os investimentos foram da ordem de R $\$ 4,5$ bilhões, 
ou seja, 80,4\% maiores em relação ao ano anterior.

O desempenho da indústria de máquinas e equipamentos também superou as expectativas em 2002. O faturamento nominal atingiu R \$ 34,4 bilhões, representando $13 \%$ de aumento em relação ao ano de 2001 , que era na ordem de $\mathrm{R} \$$ 30,2 bilhões (ESALQ- USP, 2003).

A figura 1, baseada em dados da Associação Nacional dos Fabricantes Veículos Automotores (ANFAVEA, 2004), mostra a evolução das exportações de máquinas agrícolas nos últimos 40 anos. O importante é notar que a partir de 2000 houve um grande salto nas exportações das mesmas. Os dados de 2004 são referentes somente aos meses de janeiro e fevereiro.

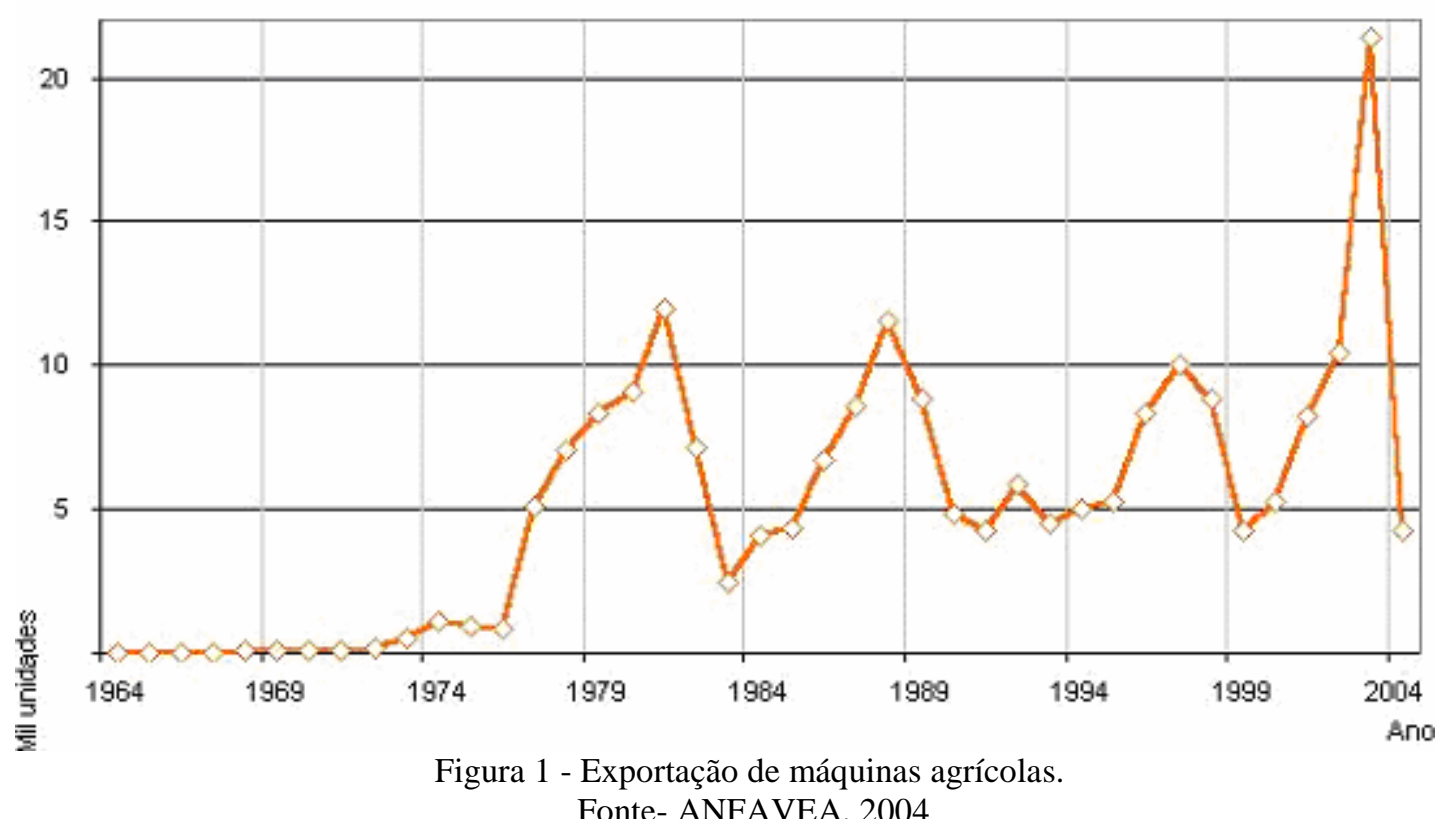

Um dos fatores motivadores para o aumento das exportações é a melhoria nos processos produtivos empregados por essas empresas. Segundo dados do Banco Nacional de Desenvolvimento Sociais (BNDES, 1995), ao longo das últimas décadas, expressivos investimentos foram feitos nas fábricas brasileiras aperfeiçoando os processos produtivos e a gestão da qualidade. Salienta-se também que modernas técnicas japonesas foram introduzidas, com ganhos significativos na administração de estoques e sensível melhoria de produtividade, ganhando competitividade mundial.

De acordo com a Associação Brasileira da Indústria de Máquinas e Equipamentos (ABIMAQ, 2003), a indústria de máquinas e implementos agrícolas dispõe de um parque industrial com mais de 300 empresas independentes, fabricando 
uma gama enorme de produtos, pois abrangem vários subsetores, que vão desde o preparo do solo, plantio, colheita, até o armazenamento e o transporte de produtos agrícolas para o consumo direto ou para a indústria alimentícia.

Para este estudo foram analisadas nove empresas do setor de máquinas e implementos agrícolas, sendo oito delas localizadas no Estado de São Paulo e uma no Estado do Paraná. A escolha dessas empresas foi devido ao fato de que, na época do desenvolvimento do trabalho, elas já apresentavam indícios de implementação de Produção Enxuta. Utilizou-se um roteiro de entrevista, que está no apêndice A deste trabalho, para responder as perguntas da pesquisa.

\subsection{Metodologia de pesquisa e desenvolvimento do trabalho}

Para a realização do presente trabalho tornou-se necessário o emprego de uma metodologia, a qual consiga desenvolvê-lo e encaminhá-lo aos objetivos finais, sendo necessário percorrer as seguintes etapas, ilustradas na figura 2.

Inicialmente foi realizada uma revisão bibliográfica, buscando um levantamento dos conceitos de Produção Enxuta, suas ferramentas e técnicas, envolvendo a leitura de livros, dissertações e artigos de revistas especializadas e científicas. Foi levantado, também, um panorama atual do setor agrícola brasileiro, especificamente o de máquinas e implementos agrícolas e identificadas as práticas de Produção Enxuta a serem pesquisadas nas empresas.

Após este primeiro levantamento foi elaborado um roteiro de entrevista, que visa responder aos objetivos desta pesquisa. Paralelamente foram identificadas as empresas do setor em estudo que vêm aplicando os conceitos de Produção Enxuta.

Em um segundo momento, uma pesquisa de campo de caráter descritivo foi desenvolvida com a realização de visitas e entrevistas utilizando o roteiro elaborado anteriormente, além da observação das atividades operacionais executadas pela empresa concernentes à pesquisa, sem interferência do pesquisador no meio em que elas ocorreram.

Após esta fase foram feitas as analises dos dados coletados e formulada a conclusão do trabalho, procurando contribuir como referência de estudo e recomendações para o setor. 


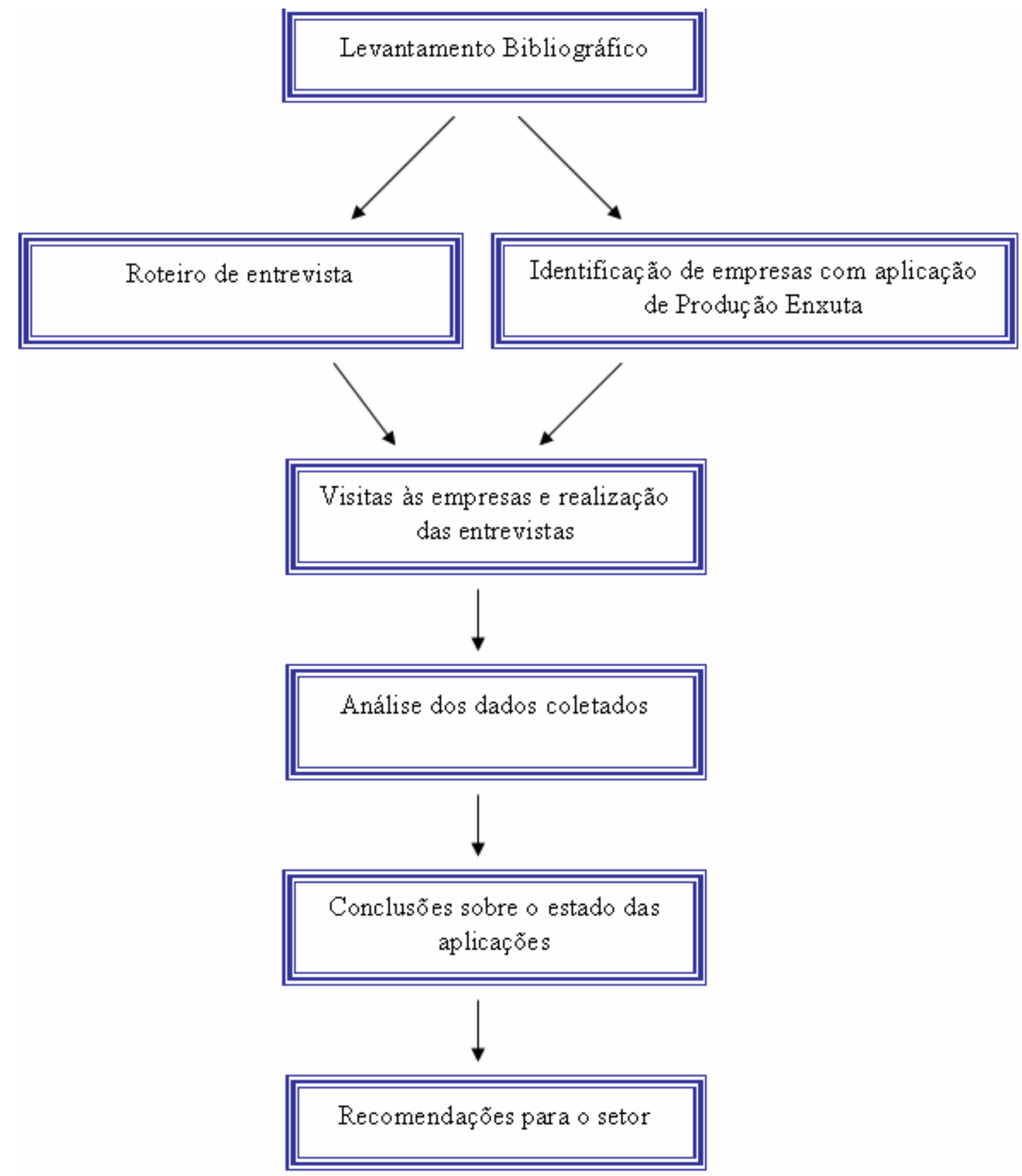

Figura 2 - Passos da metodologia de pesquisa

\subsection{Organização do Trabalho}

O presente trabalho está organizado em 5 capítulos. Neste primeiro capítulo foi feita uma contextualização e apresentação do trabalho, com a apresentação do problema e dos objetivos, a justificativa do trabalho, a metodologia do trabalho, e por fim a organização do mesmo. 
No capítulo 2, denominado de Produção Enxuta, é exposto um panorama empresarial, a filosofia de Produção Enxuta, bem como seus pilares e bases de sustentação e suas práticas.

O capítulo 3 trata dos procedimentos metodológicos para o desenvolvimento do roteiro de entrevista, que serviu como guia para conseguir responder os objetivos da presente pesquisa. Ele está nomeado como Procedimentos Metodológicos da Pesquisa.

O capítulo 4, nomeado Desenvolvimento e Apresentação dos Estudos de Casos, apresenta as empresas que foram analisadas nesta pesquisa e também os projetos Lean, esclarecendo a forma como foi conduzida a pesquisa de campo nas mesmas. Aponta a utilização do roteiro de entrevista e as entrevistas realizadas.

O capítulo 5 mostra as análises e conclusões finais do trabalho, fazendo uma análise dos projetos Lean.

No apêndice A está o roteiro de entrevista, utilizado na pesquisa de campo. E os demais apêndices (A a I) mostram as respostas dos entrevistados nas empresas. 


\section{Capítulo 2 - Produção EnXuta}

\subsection{Panorama empresarial}

Atualmente vive-se em um mundo globalizado onde, do ponto de vista comercial, as fronteiras parecem cada vez menores e as empresas para se manterem competitivas no mercado consumidor precisam realizar mudanças tanto no âmbito cultural como no produtivo, buscando obter uma vantagem competitiva sustentável sobre seus concorrentes. Caso contrário elas estão ameaçadas pela concorrência e podem até perder seus clientes.

Para Porter (1999), o meio ambiente onde as empresas atuam é como uma arena de competição, onde elas estão sujeitas as diversas forças concorrentes e tem que lidar com elas para "sobreviver". Ele analisa os efeitos que a concorrência tem sobre as empresas e as formas como elas podem enfrentá-las.

Em concordância com essa realidade surgiu no Japão, após a Segunda Guerra Mundial, um sistema produtivo diferente, chamado Sistema Toyota de Produção (TPS), adotado na época e que mais tarde passou a ser chamado Produção Enxuta (Lean Production ou Lean Manufacturing), que tenta produzir em resposta as demandas específicas do cliente, ao mínimo custo e somente quando necessário, controlando a qualidade do produto e o prazo de entrega.

\subsection{A Filosofia de Produção Enxuta}

As origens da Produção Enxuta podem ser encontradas nas inovações feitas no chão-de-fábrica da Toyota Motor Corporation no Japão, nos meados dos anos 40, chamado de TPS. Essas mudanças foram feitas para tentar responder com escassez de recursos a uma intensa competição da indústria automobilística, e representava um modelo de produção alternativo ao modelo de produção em massa (OHNO, 1988).

O termo Produção Enxuta foi popularizado no livro "A Máquina que 
Mudou o Mundo" (WOMACK, JONES e ROOS, 1990), o qual ilustra claramente a significativa diferença de desempenho obtido pela implantação desse conceito na indústria automobilística japonesa em comparação com a indústria ocidental.

Alguns autores definem o que seria a Produção Enxuta. Segundo MacDonald, Aken e Rentes (2000) a Produção Enxuta reúne uma série de princípios para eliminar desperdícios durante a produção dos produtos, buscando atingir (ou até superar) as expectativas dos clientes. Suas técnicas procuram minimizar as perdas dentro da empresa, gerando produtos a um menor custo e possibilitando à organização produzir a um preço menor e sem perda da qualidade.

Bozzone (2002) comenta que a Produção Enxuta está baseada no sistema de produção puxada, no fluxo contínuo, na eliminação de desperdícios, na qualidade na fonte e na busca por melhorias contínuas.

Maestrelli et al. (2002) descreve a Produção Enxuta como um composto de quatro programas chaves: controle de inventário, garantia da qualidade, máximo rendimento dos equipamentos e fábricas focalizadas.

Para Womack e Jones (1998) a Mentalidade Enxuta (Lean Thinking) é uma filosofia de negócio que olha com detalhe para as atividades básicas envolvidas no negócio e identifica o que é desperdício e o que é valor a partir da ótica dos clientes e usuários.

Segundo Ferro (2003) a mentalidade enxuta é uma forma de especificar valor, alinhar na melhor sequiência as ações que criam valor, realizá-las sem interrupção sempre que solicitadas e de forma cada vez mais eficaz.

Depois dos anos 90, houve uma expansão no uso da Produção Enxuta em empresas ocidentais, motivadas pelos resultados alcançados pelas orientais e atualmente ela vem sendo implementada na grande maioria dos setores industriais, obtendo resultados expressivos em diversas empresas (LEAN SUMMIT, 2002).

Este processo de expansão levou as empresas a adaptarem seus sistemas de produção de acordo com os princípios de Produção Enxuta.

Hines e Taylor (2000) descrevem os cinco princípios básicos da Produção Enxuta:

Valor: É o primeiro passo para o pensamento enxuto. Ele só pode ser definido pelo consumidor final e pode ser entendido como aquilo que os clientes estão dispostos a pagar por um determinado produto conforme as suas necessidades. Cabem às empresas a identificação de quais são essas necessidades, procurando satisfazê-las da 
melhor maneira possível e cobrando por isso um preço específico, com os lucros aumentando em função de melhorias contínuas dos processos, qualidade dos produtos e redução dos custos;

Cadeia de Valor: É o conjunto de todas as ações necessárias para levar o produto a passar pelas três tarefas gerenciais críticas a todo negócio: a tarefa de solução de problemas, ou seja, da concepção até o lançamento do produto; a tarefa de gerenciamento da informação, que vai do recebimento do produto até a entrega; e a tarefa de transformação física, que vai da matéria-prima ao produto acabado;

Fluxo: Nessa etapa deve-se fazer com que as etapas do processo produtivo, e que criam valor, fluam. A alternativa enxuta é redefinir o trabalho das funções, departamentos e empresas, permitindo a contribuição de forma positiva para a criação de valor e mostrar aos funcionários a importância de cada um na cadeia de valor;

Produção Puxada: É a capacidade da empresa em projetar, programar e fabricar exatamente o que o cliente quer. Dessa forma a empresa pode deixar que o cliente "puxe" o produto ao invés de "empurrá-lo". Com isso as demandas dos clientes se tornarão mais estáveis, porque eles saberão que podem conseguir o que querem quando necessitar. Outra vantagem para a empresa é que ela não precisará fazer campanhas de descontos destinadas a vender produtos de estoque.

Perfeição: É a realização da Produção Enxuta. Quando os quatro princípios iniciais interagem entre si criam um ciclo poderoso, pois fazer com que o valor flua mais rápido expõe os desperdícios ocultos na cadeia de valor, e conseqüentemente revelará os obstáculos ao fluxo, permitindo a eliminação dos mesmos.

O objetivo da Produção Enxuta está justamente em tentar eliminar sete tipos de desperdícios, identificados por Shigeo Shingo na Toyota do Japão e descritos por Womack e Jones (1998).

1. Superprodução: é produzir excessivamente ou cedo demais, resultando em um fluxo pobre de peças e informações.

Segundo Corrêa e Gianesi (1993) a perda por superprodução é toda produção realizada no sentido de antecipar a demanda, prevendo a requisição de produtos no futuro, tendo como resultado o excesso de inventário.

Para Guinato (2000) a perda por superprodução é a mais danosa, porque ela tende a esconder outras perdas e é mais difícil de ser eliminada. 
Existem dois tipos de perdas por superprodução (CORRÊA E GIANESI, 1993): Perda por produzir demais (superprodução por quantidade), ou seja, é a perda por fabricar além do volume programado ou solicitado, sobrando peças ou produtos. Este tipo de desperdício é inadmissível na Produção Enxuta. Perda por produzir antecipadamente (superprodução por antecipação), ou seja, é a perda decorrente de uma produção realizada antes do momento necessário de produtos ou peças, resultando na estocagem até a ocasião de serem consumidas ou processadas as etapas seguintes, respectivamente. Este tipo de desperdício é o mais trabalhado pela Produção Enxuta.

2. Fabricação de produtos defeituosos: é resultada através da fabricação de produtos que apresentem alguma de suas características de qualidade fora do padrão requerido ou especificado, e que portanto, não satisfaz aos requisitos de uso.

Os problemas de qualidade são um dos maiores responsáveis pelos desperdícios dentro do processo de fabricação, gerando refugo de materiais, disponibilidade de mão-de-obra para tratar os refugos e a necessidade de inspeção (IMAI, 1996). Sua eliminação dependerá de aplicações sistemáticas de métodos de controle de qualidade na fonte, ou seja, a causa-raíz do defeito, e utilização da filosofia de Administração da Qualidade Total. Também a organização deverá incentivar a prática de empowerment dos funcionários, dando autoridade e autonomia para pararem o processo produtivo sempre que houver a constatação de ocorrência de defeitos.

3. Estoque: está sob forma de estoque de matéria-prima, material em processamento e produto acabado.

É considerado todo e qualquer produto mantido em estoque e que resulta em um maior custo operacional, ocupando mais espaço e exigindo equipamento adicional, entre outros (WOMACK e JONES, 1998).

Segundo Guinato (2000) existe uma grande barreira ao combate às perdas por estoque, já que os mesmos proporcionam a "vantagem" de aliviar os problemas de sincronia entre os processos.

A Produção Enxuta utiliza a estratégia de diminuição gradativa dos estoques intermediários como forma de identificar outros problemas no sistema, ocultos pelo alto nível de estoques.

4. Processamentos inapropriados: estão relacionadas ao uso indevido ou inadequado da tecnologia, resultando em desperdício dentro do processo produtivo.

Segundo Ribeiro (1986) são as parcelas do processamento que poderiam ser eliminadas sem afetar as características e funções básicas do produto ou serviço. 
Também são consideradas as situações, nas quais o desempenho do processo encontrase aquém da condição ideal. Um exemplo seria a baixa velocidade de corte de um torno por força de problemas de ajustes de máquina ou manutenção.

5. Transportes desnecessários: são as movimentações excessivas de bens ou informações. Resultam em aumento do lead time de fabricação e do custo do produto, devendo por isso ser eliminada ou reduzida ao mínimo possível (RIBEIRO, 1986).

Para conseguir melhorias significativas de redução das perdas de transporte, as empresas fazem alterações de layout, que dispensem ou eliminem as movimentações de material.

6. Espera: originada de um intervalo de tempo no qual nenhum processamento, transporte ou inspeção é executado, ficando o lote parado à espera de um "sinal verde" para seguir em frente no fluxo de produção.

Segundo Guinato (2000) podem-se destacar três tipos de perda por espera: Perda por espera no processo, que acontece quando o lote inteiro aguarda o término da operação que está sendo executada no lote anterior, até que a máquina, dispositivo e/ou operador esteja disponível para o início da operação; Perda por espera do lote, ou seja, é a espera que cada peça componente de um lote é submetida até que todas as peças do lote tenham sido processadas. Esta perda, embora comum, é muito danosa para as empresas que submetem sua produção em processos produtivos em massa. Perda por espera do operador, gerada pela ociosidade do operador, quando o mesmo é forçado a permanecer junto à máquina, acompanhando o processamento do início ao fim ou quando ocorre o desbalanceamento de operações.

7. Movimentações desnecessárias: caracterizada por todo movimento corporal de uma pessoa não diretamente relacionada à agregação de valor. Estas perdas estão relacionadas aos movimentos desnecessários realizados pelos operadores na execução de uma operação.

Segundo Hines e Taylor (2000) quando se definem os desperdícios, costuma-se classificar em três tipos as atividades organizacionais, que são elas:

Atividades que agregam valor, ou seja, são aquelas que, aos olhos do cliente final, agregam valor ao produto ou serviço;

Atividades que não agregam valor, que são aquelas que não agregam valor ao consumidor final e que são desnecessárias para a produção. Elas devem ser eliminadas a curto e médio prazo; e 
Atividades que não agregam valor, mas que são necessárias. Estas atividades são mais difíceis de serem eliminadas em curto prazo, necessitando de um planejamento bem elaborado para eliminá-las.

Estes autores afirmam que cerca de $60 \%$ das atividades podem ser classificadas como atividades que não agregam valor, evidenciando um ambiente propício para a realização de esforços para reduzir os desperdícios nas empresas.

Como a Produção Enxuta teve suas bases no Sistema Toyota de Produção (TPS) torna-se necessária à abordagem deste sistema produtivo para entender melhor sua filosofia gerencial, pois a Produção Enxuta, como qualquer outro sistema de produção existente, também depende de algumas técnicas de apoio para sua sustentação. Isto ocorre através da boa implementação de dois pilares que buscam a total eliminação do desperdício: JIT e Jidoka (OHNO, 1988).

\subsection{Pilares de Sustentação}

O JIT e o Jidoka estão incorporados ao TPS e servem como pilares de sustentação do mesmo como mostra a figura 3. Outros componentes também fazem parte do TPS e serão descritos a seguir.

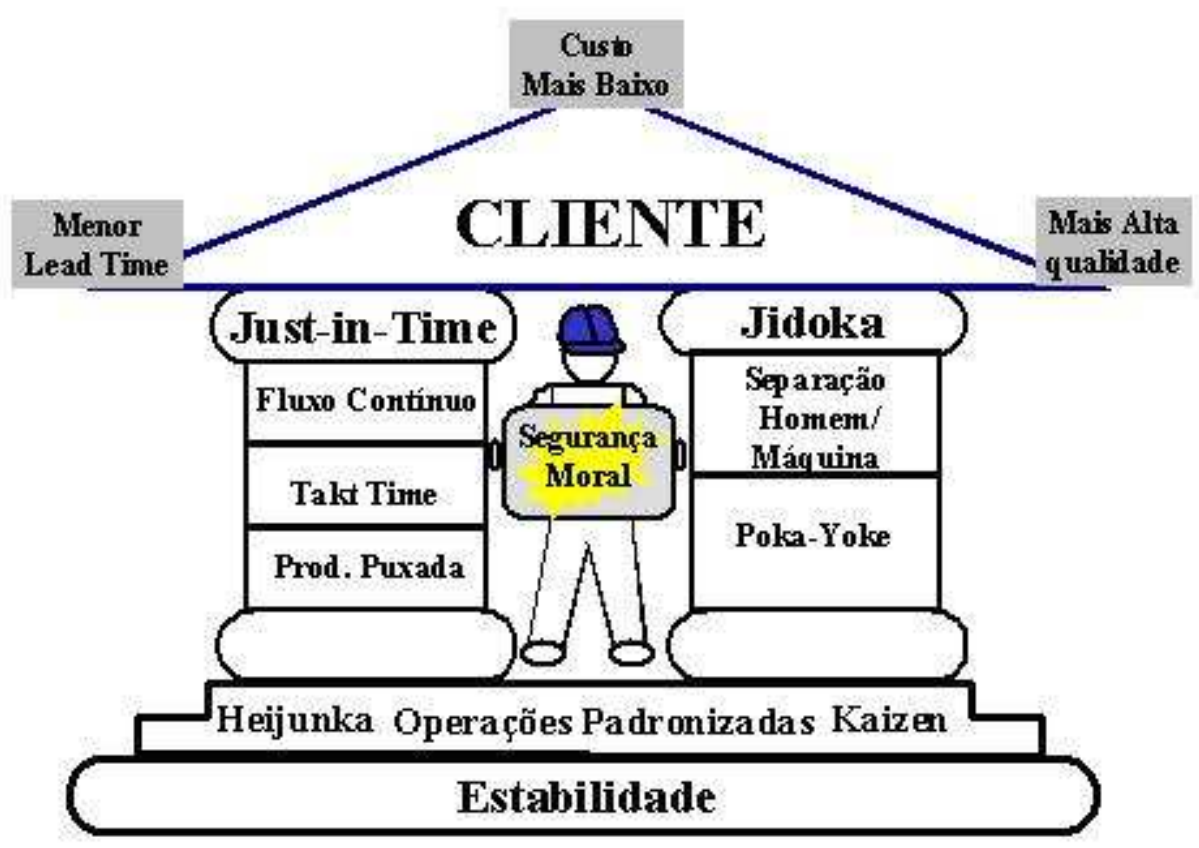

Figura 3 - A estrutura do Sistema Toyota de Produção.

Fonte - GUINATO, P. 2000 


\subsubsection{Just-In-Time}

O conceito Just-in-time (JIT) é uma expressão em inglês adotada pelos japoneses, mas que não se sabe precisar quando ela começou a ser utilizada. Fala-se do surgimento da expressão na indústria naval, sendo incorporada, logo a seguir, pelas indústrias montadoras (GUINATO, 2000; SHINGO, 1996a).

O Just-In-Time significa que cada processo deve ser suprido com os itens certos, no momento certo, na quantidade certa e no local certo. Como exemplo, no processo de montagem das peças e componentes necessários para montar um carro, os tipos de submontagens necessárias do processo precedente devem chegar à linha de produção no tempo e quantidades necessárias (MONDEN, 1998).

O objetivo do JIT é identificar, localizar e eliminar as perdas, garantindo um fluxo contínuo de produção (OHNO, 1988).

A figura 4 compara o fluxo de produção tradicional com o fluxo unitário contínuo, ficando clara a eliminação das perdas por estoque, perdas por espera e a redução do lead time de produção.
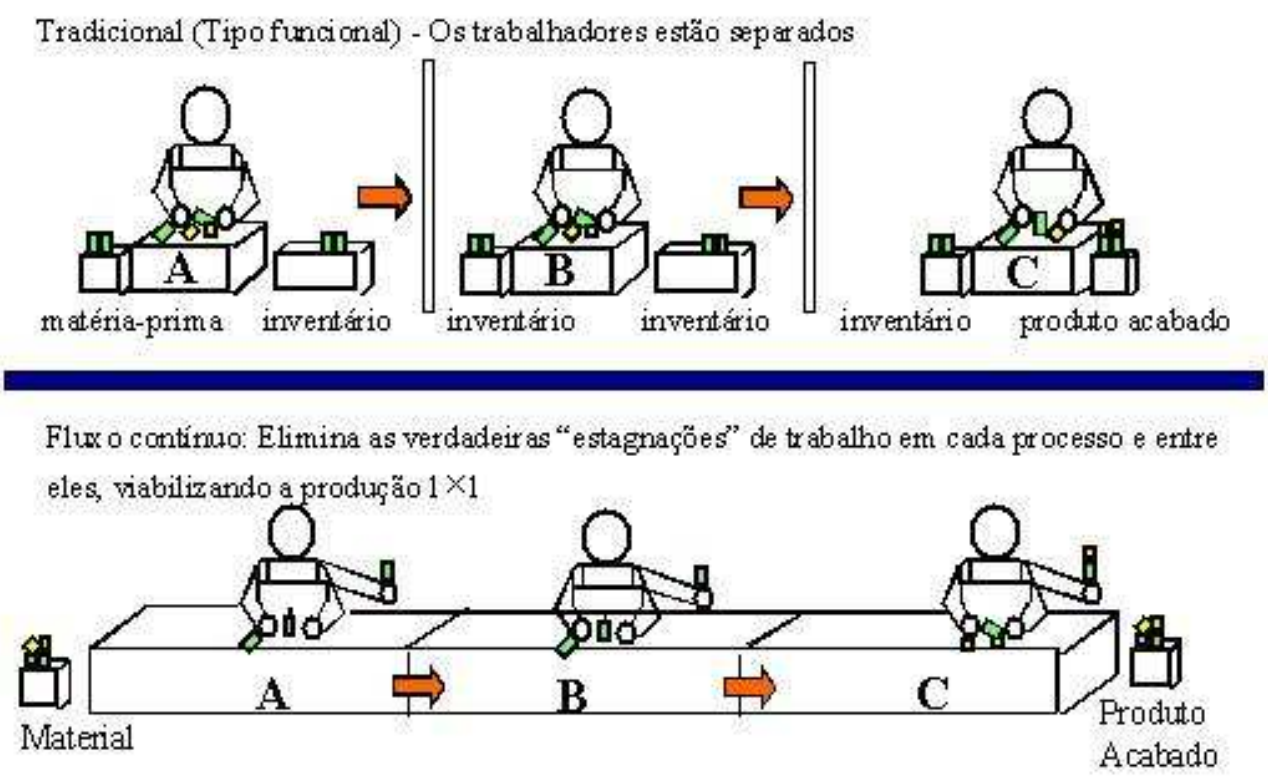

Figura 4 - Fluxo de Produção Tradicional versus Fluxo Unitário Contínuo. Fonte - GUINATO, P. 2000

Na implementação de um fluxo contínuo de produção torna-se necessário um perfeito balanceamento das operações ao longo da célula de fabricação/montagem. 
$\mathrm{Na}$ abordagem da Produção Enxuta o balanceamento das operações difere da abordagem tradicional.

Conforme demonstra a figura 5, o balanceamento tradicional procura nivelar os tempos de ciclo de cada trabalhador, de forma a fazer com que ambos trabalhadores recebam cargas de trabalho semelhantes. O tempo de ciclo é o tempo total necessário para que um trabalhador execute todas as operações alocadas a ele (GUINATO, 2000).

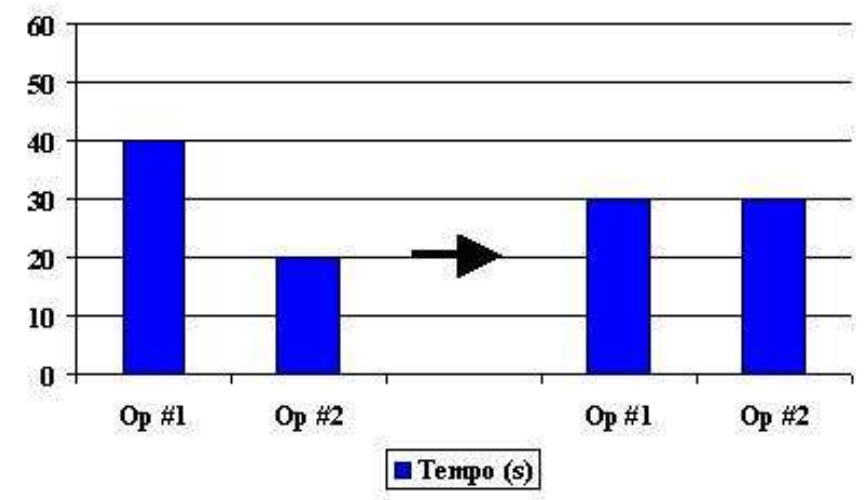

Figura 5 - Balanceamento de Operações Tradicional. Fonte - GUINATO, P. 2000

$\mathrm{Na}$ Produção Enxuta o balanceamento das operações está fundamentalmente ligado ao conceito do takt time, que sincroniza o ritmo da produção para acompanhar a velocidade das vendas. O takt time é o tempo necessário para produzir um componente ou um produto completo, baseado na demanda do cliente. (ROTHER e SHOOK, 1998).

O takt time é um número de referência, que mostra o ritmo que cada processo precisa estar produzindo e o que precisa melhorar.

O takt time é dado pela seguinte fórmula:

$$
\text { Takt time }=\frac{\text { Tempo total disponível }}{\text { Demanda do cliente }}
$$

Na lógica da Produção Enxuta, a produção é puxada, ou seja, o cliente solicita o produto ou serviço e a partir deste momento inicia-se a produção. $\mathrm{Na}$ 
Produção Enxuta, o ritmo da demanda do cliente final deve repercutir ao longo de toda a cadeia de valor, desde o armazém de produtos acabados até os fornecedores de matérias-primas. As vantagens de trabalhar em sistema de produção puxada é que se produz somente o que for vendido.

\subsubsection{Jidoka}

O outro pilar de sustentação do TPS é o Jidoka e pode ser traduzido como autonomação e interpretada como controle autônomo de defeitos (MONDEN, 1998).

Em 1926, quando a família Toyoda ainda concentrava seus negócios na área têxtil, Sakichi Toyoda inventou um tear capaz de parar automaticamente quando a quantidade programada de tecido fosse alcançada ou quando os fios longitudinais ou transversais da malha fossem rompidos. Desta forma, conseguiu-se dispensar a atenção constante do operador durante o processamento, viabilizando a supervisão simultânea de diversos teares. Esta inovação revolucionou a tradicional e centenária indústria têxtil (GUINATO, 2000).

A invenção de Sakichi Toyoda, aplicada às máquinas da Toyota Motor Company, deu origem ao conceito de Jidoka ou autonomação, como também é conhecido. Segundo Monden (1998) autonomação é uma técnica para detectar e corrigir defeitos de produção e incorpora os seguintes dispositivos: um mecanismo para detectar anormalidades ou defeitos e um mecanismo para parar a máquina ou linha de produção quando ocorrem as anormalidades ou defeitos.

A idéia central é impedir a geração e propagação de defeitos e eliminar qualquer anormalidade no processamento e fluxo de produção. Quando a máquina interrompe o processamento ou o operador pára a linha de produção, imediatamente o problema torna-se visível ao próprio operador, aos seus colegas e à sua supervisão. Isto desencadeia um esforço conjunto para identificar a causa fundamental e eliminá-la, evitando a reincidência do problema e conseqüentemente reduzindo as paradas da linha.

O Jidoka é composto pela separação do homem e a máquina e pelo Pokayoke comentados a seguir.

Segundo Guinato (2000) a separação entre a máquina e o homem é um requisito fundamental para a implementação do jidoka. Na prática, a separação que ocorre é entre a detecção da anormalidade e a solução do problema. A detecção pode ser uma função da máquina, pois é técnica e economicamente viável, enquanto a solução ou 
correção do problema continua como responsabilidade do homem. Desta forma, a transferência das atividades manuais e funções mentais (inteligência) do homem para a máquina, permitem que o trabalhador opere mais de uma máquina simultaneamente, como mostra a figura 6.
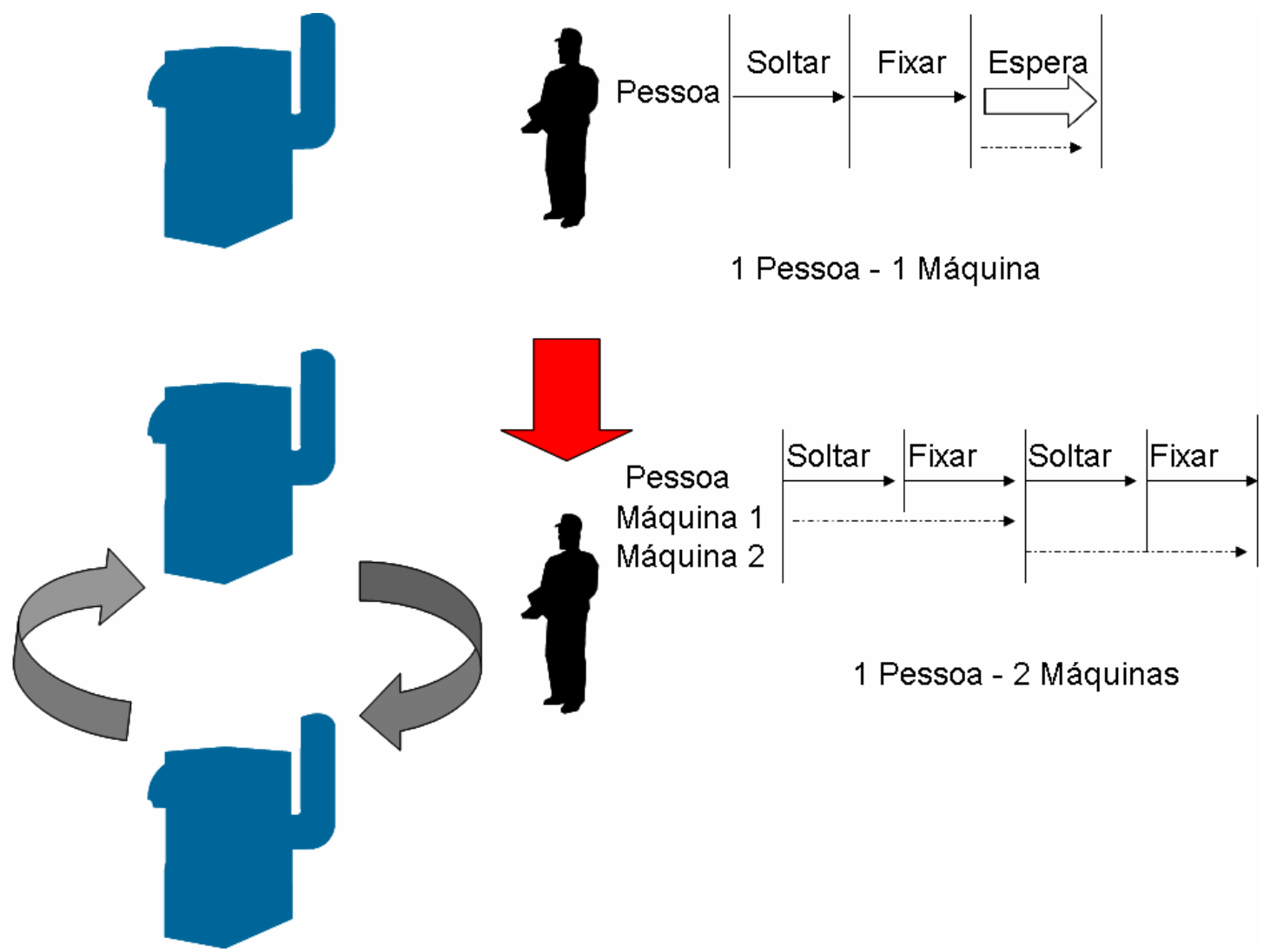

Figura 6 - Separação entre o Homem e a Máquina.

Fonte - GUINATO, P. 2000

O segundo componente do pilar jidoka é o dispositivo poka-yoke. O poka-yoke é um mecanismo de detecção de anormalidades que, acoplado a uma operação, impede a execução irregular de uma atividade. O poka-yoke é uma forma de bloquear as principais interferências na execução da operação (MONDEN, 1998).

Segundo Shingo (1996) esta é uma técnica de garantia da qualidade que foi desenvolvida no Japão nos anos sessenta, onde a idéia principal era mostrar que o ser humano é passível de cometer erros, que podem ser facilmente detectados e corrigidos através da utilização de mecanismos simples.

Os dispositivos poka-yoke são as maneiras pela quais o conceito do jidoka é colocado em prática. A aplicação dos dispositivos poka-yoke permite a separação entre a máquina e o homem e o decorrente exercício do jidoka. 


\subsection{Base de sustentação}

Os pilares JIT e Jidoka estão assentados sobre uma base formada pelas operações padronizadas, heijunka (nivelamento da produção) e kaizen (melhoria contínua), que formam a estabilidade do processo (Figura 3). O kaizen e a estabilidade estão descritos a seguir e as operações padronizadas estão descritas no item 2.5.2 e o heijunka está descrito no item 2.5.5 deste capítulo.

\subsubsection{Kaizen}

Um dos componentes da base sobre a qual estão assentados os pilares do TPS é o kaizen.

Kaizen é a melhoria incremental e contínua de uma atividade, focada na eliminação de perdas (muda), de forma a agregar mais valor ao produto/serviço com um mínimo de investimento (GUINATO, 2000).

Segundo Womack e Jones (1998) para a implementação do pensamento enxuto, o princípio fundamental é a transparência, onde ocorre o desdobramento da política em um processo aberto, destinado a alinhar pessoas e recursos com tarefas de melhorias. Sendo assim, através do kaizen é possível alterar a cultura das organizações, fazendo com que os operários façam parte e contribuam no processo de melhoria contínua.

Segundo Rother e Shook (1998) o kaizen pode ser dividido em dois níveis:

Kaizen de fluxo: Seu enfoque está na melhoria do fluxo de valor e é dirigido ao gerenciamento. Envolve planejamento e execução de melhorias de alto nível.

Kaizen de processo: Seu enfoque está na melhoria dos processos individuais, eliminando desperdícios e está dirigido às equipes e líderes de trabalho. Envolvem modificações localizadas em pontos específicos do processo produtivo.

Para Araujo e Rentes (2005) o importante é que a empresa desenvolva um plano diretor de mudanças. Este plano deve ser desenvolvido de forma consensual com diversos segmentos da empresa e deve ser compartilhado com todos os envolvidos no processo de mudança. 


\subsubsection{Estabilidade}

A estabilidade dos processos é a base de todo o TPS. Somente processos capazes, sob controle e estáveis podem ser padronizados de forma a garantir a produção de itens livres de defeitos (resultante do pilar Jidoka), na quantidade e momento certo (resultantes do pilar JIT).

A estabilidade dos processos é um pré-requisito para a implementação do TPS. O planejamento da produção e das próprias ações de melhoria só pode ser executado em um ambiente sob controle e previsível. O processo de identificação do desperdício ao longo da cadeia de valor deve ser conduzido em condições estáveis, caso contrário o que se verifica não é solução de problemas de forma sistemática, mas a prática de resolver problemas do dia-a-dia.

\subsection{Práticas de Produção Enxuta}

A partir desta base de sustentação de Produção Enxuta, existem diversas técnicas, ferramentas e conceitos, que podem ser implantados nas empresas, para que elas consigam eliminar os desperdícios encontrados no seu ambiente produtivo.

Muitas dessas técnicas, ferramentas e conceitos, que estão apresentados aqui neste trabalho, são tratados, erroneamente por algumas empresas como sendo sistemas independentes e aplicados isoladamente.

Segundo Carneiro (2004) dentro do pensamento enxuto é importante lembrar que para o perfeito funcionamento desse sistema as empresas devem se esforçar ao máximo para implantar de forma correta e ao tempo certo cada uma das técnicas, ferramentas e conceitos, que são utilizadas dentro deste processo produtivo, procurando obter uma completa interação entre eles e permitir com isso obter um maior lucro para a empresa.

Segundo Ferreira (1975), práticas são atos ou efeitos de praticar, usar ou aplicar a teoria. Neste trabalho tanto as técnicas, ferramentas e conceitos, descritos na literatura e utilizados nas empresas, serão tratados genericamente como práticas da Produção Enxuta. Elas estão descritas a seguir.

\subsubsection{S}

A organização do trabalho é o ponto mais básico na implantação da Produção Enxuta, devendo ser o 5S uma das primeiras práticas a serem implantadas. 
O 5S refere-se a cinco palavras japonesas, que constituem uma técnica simples de preparação do ambiente de trabalho, preparando os funcionários para uma mudança de cultura empresarial, de forma que estes possam ter mais responsabilidades do que a simples operação de um determinado equipamento.

$5 \mathrm{~S}$ objetiva a educação, o treinamento e busca da qualidade através de constante aperfeiçoamento da rotina de trabalho.

Os conceitos fundamentais do $5 \mathrm{~S}$ devem ser entendidos, incorporados e praticados por todos os níveis hierárquicos, dos empregados à gerência, visando entre outras metas, evitar desperdícios e garantir um ambiente de trabalho cada vez mais saudável. Os 5S são definidos como (OSADA, 1992):

Seiri (Senso de utilização): Separar todo o material necessário dentro da empresa e descartar tudo o que for desnecessário, seguindo a premissa básica de que tudo o que não vai ser utilizado um em período de trinta dias deve ser eliminado;

Seiton (Senso de Ordem): Organizar tudo o que sobrar após a realização do Seiri, classificando todos os itens por sua utilidade e arrumando-os adequadamente, a fim de minimizar o tempo e esforço de busca, designando um local e a quantidade para cada item. Este estágio é considerado o primeiro para se trabalhar em produção puxada, pois todos os itens passam a ter seu local definido.

Seiso (Senso de limpeza) É a limpeza do local de trabalho, abrangendo máquinas, ferramentas, chão, paredes e outras áreas. Esta etapa é primordial, pois através desta limpeza os operários podem encontrar vazamentos, parafusos soltos, etc.; que uma vez certificados podem ser facilmente resolvidos.

Seiketsu (Senso de padronização) É a manutenção da organização, arrumação e limpeza, dando ênfase no gerenciamento visual.

Shitsuke (Senso de autodisciplina): Ligada à autodisciplina e criar o hábito de se engajar nos projetos $5 \mathrm{~S}$.

Após a implementação dos $5 \mathrm{~S}$ a empresa deve confirmar se todos os passos estão sendo seguidos, além de verificar se todos os funcionários estão participando do processo de reorganização e melhoria do ambiente de trabalho.

A implantação e sucesso dos $5 \mathrm{~S}$ estão relacionados a três pontos chaves: (TAKAHASHI e OSADA, 1993)

Disciplina no ambiente de trabalho, que pode ser conseguida melhorando o nível de gerenciamento dos parâmetros que avaliem se todos estão obedecendo às 
regras estabelecidas;

Ambiente de trabalho limpo, limpando os equipamentos e o local de trabalho as pessoas ficam conscientes da importância de um ambiente agradável;

Criação de um ambiente de trabalho propício ao gerenciamento visual, dessa forma, os erros ficam mais fáceis de serem identificados e corrigidos.

\subsubsection{Operações padronizadas}

A operação padronizada pode ser definida como um método efetivo e organizado de produzir sem perdas. Para Spear e Bowen (1999), a padronização é o grande segredo do sucesso do TPS. Os autores enumeram quatro regras básicas para uma empresa conseguir padronizar suas operações, descritas a seguir:

1. Todo trabalho deve ser altamente especificado quanto ao conteúdo, seqüência, andamento e resultado. Esta regra está relacionada com a execução das tarefas e, assim que se detecta um desvio, o executante e seu supervisor podem tomar as providências necessárias imediatamente e decidir se é preciso treinar novamente o operador ou modificar o padrão utilizado.

2. Cada conexão cliente-fornecedor tem que ser direta e deve existir uma forma ambígua de se fazer solicitações e receber respostas. A regra 1 explica como as pessoas realizam seu trabalho individual, já a segunda mostra como se conectam umas as outras, estando relacionadas com as conexões do fluxo produtivo. A relação clientefornecedor fica clara, não havendo confusão sobre, por exemplo, quem é o fornecedor, número de unidades ou tempo para entrega.

3. O caminho para cada produto ou serviço deve ser simples e direto. Portanto as linhas de produção devem ser projetadas para que cada produto ou serviço tenha um caminho específico. Isso não significa que cada caminho deva ser dedicado a apenas um produto ou serviço, e sim que não haverá ambigüidade sobre quais máquinas estão envolvidas na linha produtiva.

4. Qualquer melhoria deve ser feita de acordo com o método científico, sob a orientação de um instrutor, no nível organizacional mais baixo possível. Este método científico está relacionado à reflexão que se é exigida quando um operador se depara com um problema e tem que tentar resolvê-lo da melhor maneira possível. Os trabalhadores fazem as melhorias e seus supervisores fornecem orientação e assistência. 
Quando se tratam de melhorias complexas é criada uma equipe de pessoas diretamente afetadas, juntamente com o responsável por supervisionar os fluxos envolvidos.

Segundo Monden (1998) as operações padronizadas têm três objetivos principais, sendo eles:

A obtenção da alta produtividade através do trabalho dos operários sem qualquer movimento perdido;

Obter o balanceamento de linha entre todos os processos em termos de tempo de produção. Neste caso é utilizado o conceito de takt time; e

Somente uma quantidade mínima de material em processo deve ser manipulada pelos operários.

A padronização das operações procura obter o máximo de produtividade através da identificação e padronização dos elementos de trabalho que agregam valor e da eliminação das perdas. O balanceamento entre os processos e a definição do nível mínimo de estoque em processamento também são objetivos da padronização das operações (GUINATO, 2000).

Segundo Spear e Bowen (1999) a padronização das tarefas exige que os gerentes e supervisores sejam capazes e tenham vontade de se engajarem no questionamento dos problemas para facilitar a aprendizagem do como fazer.

\subsubsection{Layout Celular}

Como pontos básicos, o layout celular apresenta a divisão dos processos de fabricação em grupos de família de peças ou produtos, onde as peças movem-se pela célula e podem ser controladas pelo sistema kanban. Ele é caracterizado por estar agrupado de acordo com máquinas de função ou tipo diferentes, de acordo com a necessidade da família de produtos que é produzida nesta linha de produção (BLACK, 1998).

Segundo Monden (1998) o layout celular permite a flexibilização da produção através do ajuste e reprogramação dos operadores, sendo isto a mais notável vantagem deste layout, pois para qualquer alteração na quantidade de produção, ou seja, variação da demanda pode-se aumentar ou reduzir o número de operadores necessários. Além disto, torna-se possível reduzir os custos operacionais e eliminar desperdícios no processo produtivo, atendendo às necessidades dos clientes. Para isto são necessários três pré-requisitos: 
O projeto estar adequado ao layout das máquinas;

Os operadores serem versáteis e bem treinados; e

Fazer uma avaliação contínua e revisões periódicas das rotinas de operações padronizadas.

Segundo Slack et al. (1999) o layout celular possui as seguintes características:

Os lotes são pequenos ou médios;

Ajusta-se ao just-in-time;

Os produtos e roteiros de produção são variados; e

As máquinas e equipamentos necessários para a produção da família são agrupados preferencialmente de forma de "U".

A disposição do layout celular parece com o layout em linha, no qual são executadas todas as operações produtivas, a diferença é que o layout celular permite uma maior flexibilidade de produção. Segundo Black (1998) esta flexibilidade é alcançada com os operadores movendo-se entre as máquinas, carregando e descarregando peças.

Um exemplo de layout celular, em forma de U, está ilustrado na figura 7. Os números 1, 2 e 3 representam os operadores. Pode-se notar, nesta figura, que existe uma quantidade três vezes menor de operadores do que de máquinas.

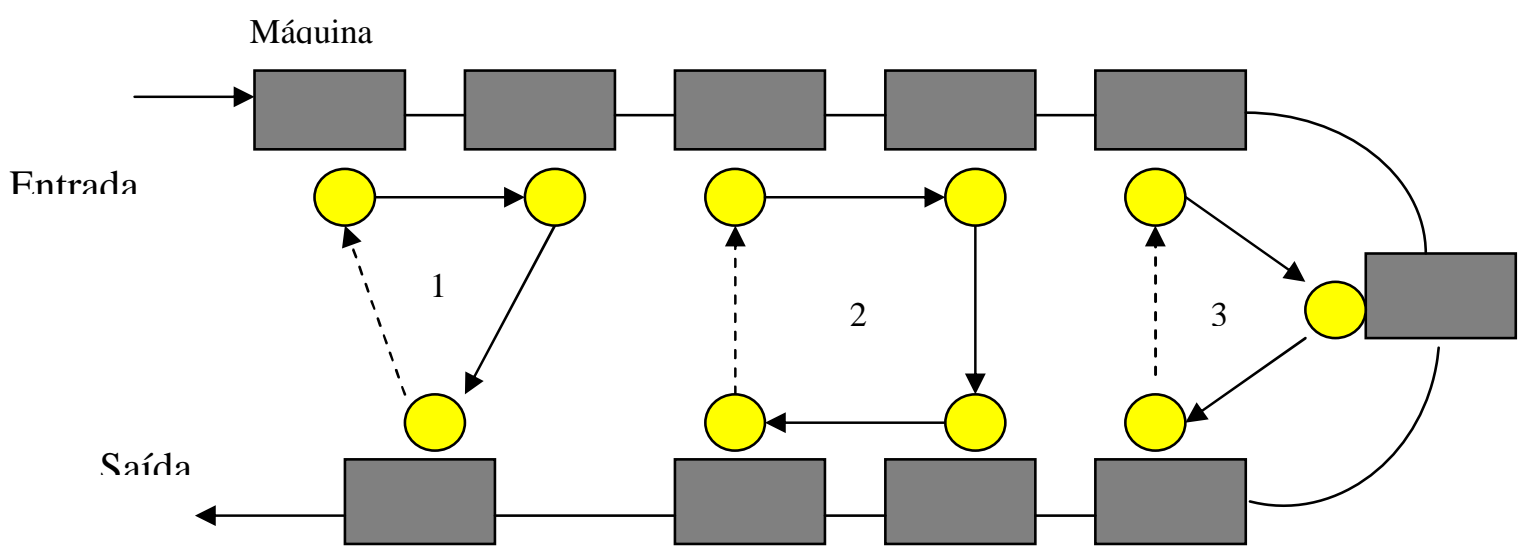

Figura 7 - Layout em forma de U. Fonte - MONDEN, Y. 1998

Segundo Yoshinaga apud Medeiros (2002) as etapas para a implantação do layout celular são:

Treinamento da direção da empresa e de todos os funcionários e visitas a outras fábricas; 
$>$ Comprometimento das pessoas;

Seleção das famílias de peças;

Escolha das máquinas envolvidas na operação;

Dimensionamento da célula quanto às máquinas, ferramentas e outros recursos;

Definição do layout da célula;

Determinação dos tempos de máquinas e de homens em função do tempo de ciclo;

Utilização de troca rápida (setup) de ferramentas e dispositivos;

Determinação da época e prazo para a mudança, com estabelecimento dos recursos necessários; e

Treinamento “in loco" e implementação.

Como foi abordado pela literatura anteriormente, layout celular é um arranjo físico normalmente orientado para a produção puxada (just-in-time), e relacionado com a produção em famílias de produtos. Também se relaciona com o emprego de funcionários multifuncionais, operações padronizadas e utilização de troca rápida (setup), abordada a seguir.

A troca rápida é conhecida como SMED (Single-Minute Exchange of Die) e foi originalmente desenvolvida para melhorar os tempos de setup de ferramentas das máquinas e tempo de passagem das peças.

Segundo Shingo (1996b) o sistema SMED é uma teoria e um conjunto de técnicas, que permitem melhorar o desempenho do setup do equipamento e as operações de troca para uma gama de um dígito em termos de minutos (single-minute range). É importante ressaltar que pode não ser possível alcançar este tempo em todos os setups, mas o SMED consegue reduzir drasticamente os tempos de setup em quase todos os casos.

Nishida (2005) comenta que o ideal seria ter um setup com tempo de troca igual a zero, mas isto só é possível se houver uma linha de produção com máquinas e equipamentos dedicados e dimensionados a um único fluxo de valor.

Para determinar o tempo de setup disponível em uma linha produtiva é preciso: (NISHIDA, 2005)

1. Determinar o tempo disponível para realizar o setup (tempo de trabalho disponível - tempo gasto na produção); 
2. Determinar o número de setups a serem realizados; e

3. Dividir o resultado de (1) por (2), obtendo o tempo para o setup da máquina.

A figura 8 mostra um exemplo de determinação do tempo de setup.

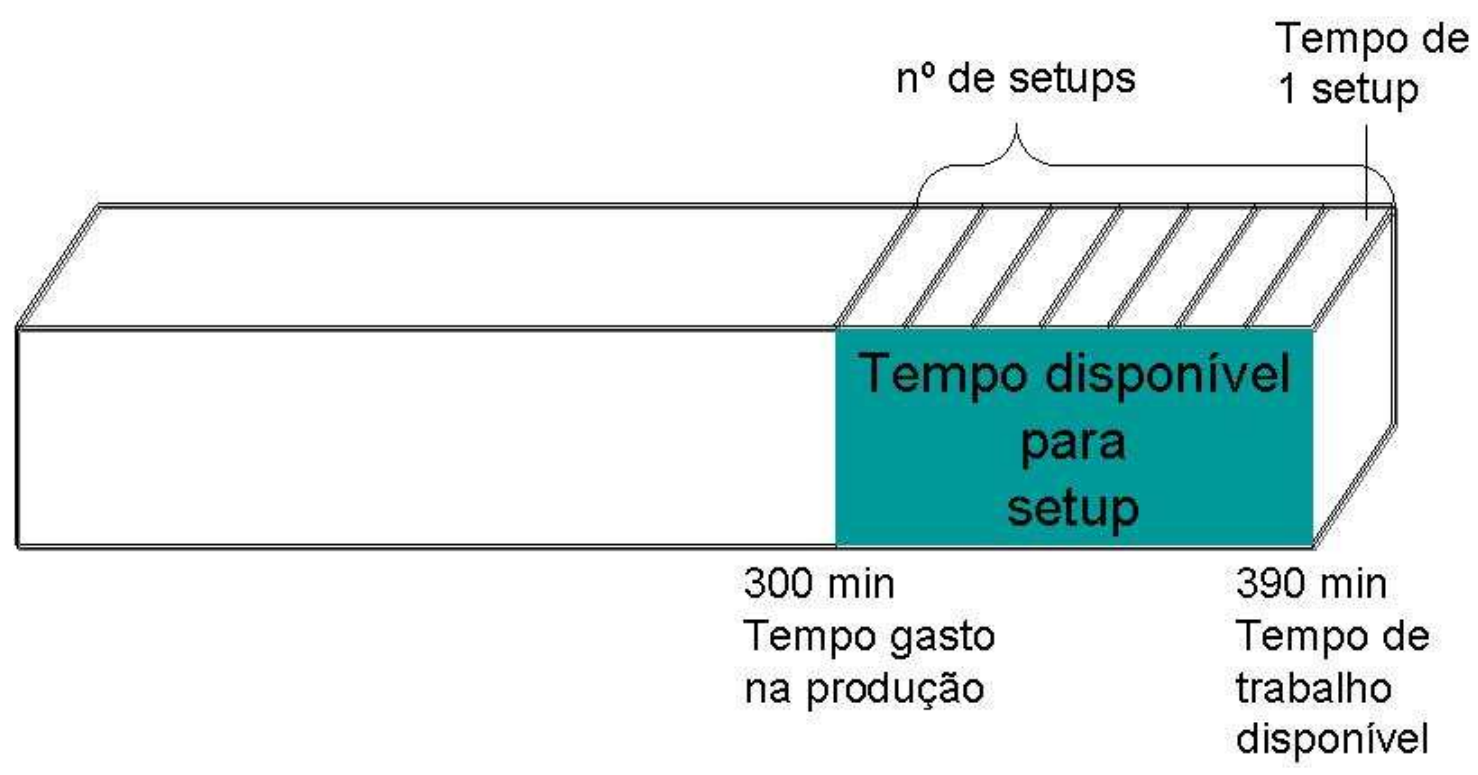

Figura 8 - Determinação do tempo do setup.

Fonte - NISHIDA, L. T. 2005

Quando se tem um setup rápido pode-se nivelar a produção, trabalhar em pequenos lotes, diminuir os estoques, aumentar a flexibilidade e atender mais rapidamente a demanda dos clientes. Neste trabalho foi visto se houve o emprego de alguma técnica de redução de setup, pelas empresas pesquisadas e como foram utilizadas.

\subsubsection{Kanban}

Outra prática muito utilizada pelas empresas é o kanban. O kanban é um termo japonês que significa cartão e é uma ferramenta para controlar de forma coordenada as quantidades de produção em todos os processos no tempo exato (MONDEN, 1998).

O kanban é considerado um sistema puxado de controle e movimentação de material, o qual compreende um mecanismo que dispara a movimentação de um material de uma operação para a seguinte. Ele trabalha de forma inversa ao sistema tradicional de produção, pois através de um controle visual conseguido pelo uso deste cartão, o operador do processo toma a decisão de fabricação de um determinado item 
quando percebe que os itens já foram consumidos, ao invés do sistema tradicional de ordens de produção.

O kanban acaba sendo uma forma simples de controlar a produção, assegurando a existência de materiais suficientes para dar continuidade no processo produtivo, garantindo que apenas as peças necessárias no processo seguinte sejam fabricadas.

Segundo Moura (1992) o kanban é um dos elementos essenciais para a implantação do sistema JIT, que é um dos pilares do TPS, uma vez que reduz o tempo de espera, diminui os estoques, melhora a produtividade e interliga todas as operações em um fluxo uniforme e ininterrupto.

Para Ribeiro (1986) o cartão kanban é responsável pela comunicação e funcionamento de todo o sistema de produção, não existindo um modelo padronizado, mas que deve ter no mínimo as informações necessárias para a perfeita operação conforme as características de cada empresa.

Para Monden (1998) existem 2 tipos de kanban: o de retirada/ transporte e o de produção:

Os kanbans de retirada são utilizados para retirar e movimentar peças do almoxarifado ou de processos anteriores. Seu número é calculado com base no consumo de cada item pela linha e pelos intervalos entre os abastecimentos; e

Os kanbans de produção servem para disparar a produção. Eles têm uma quantidade fixa, calculada com base na demanda do cliente (interno ou externo).

Existem basicamente três tipos de sistemas de kanban: com um cartão, com dois cartões e o de sinal (RENTES, 2003).

Sistema kanban de um cartão: é caracterizado por possuir apenas um local de estoques, ou seja, supermercado entre o fornecedor e seu cliente, que pode ser um processo produtivo ou não. Neste caso o único cartão existente é o kanban de produção e o supermercado de produtos do processo fornecedor fica concentrado junto ao cliente, conforme o passo (a) da figura 9. À medida que este último vai consumindo as peças, os cartões, que estavam junto às embalagens, são colocados no quadro (b).

A existência de cartões no quadro dá a permissão para a linha produzir aquelas peças, na quantidade definida no cartão. Quando isso acontece, o operador retira o cartão do quadro e dá início à fabricação (c). Quando fica pronta a produção, o operador junta o cartão ao container cheio e coloca no supermercado (d). 


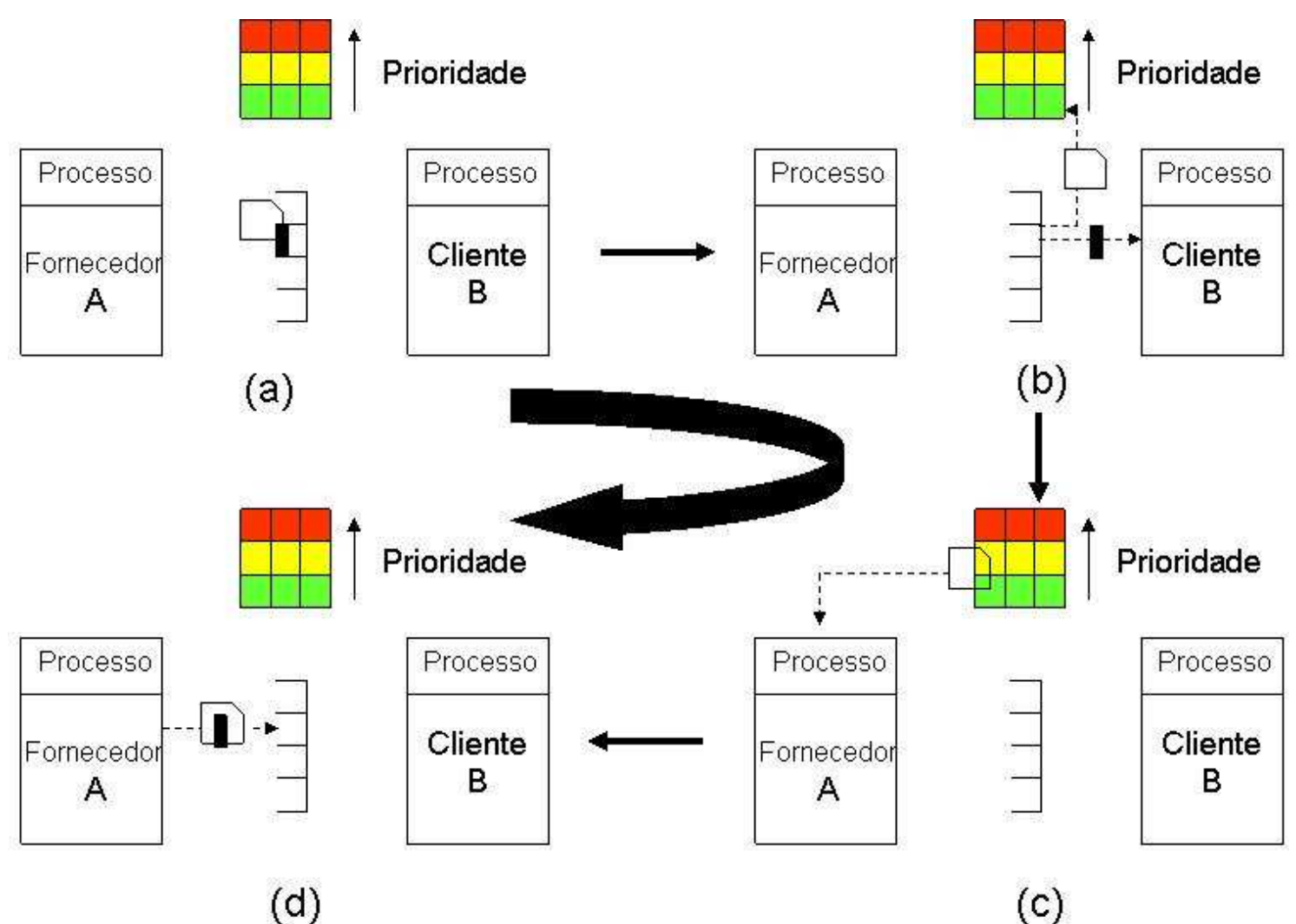

Figura 9 - Sistema kanban de 1 cartão Fonte - RENTES, 2003

Sistema kanban de dois cartões: é caracterizado pela presença tanto do kanban de produção quanto do de retirada, como mostra a figura 10. As embalagens, que ficam no supermercado do fornecedor, têm fixado nelas os kanbans de produção, as que ficam junto ao cliente têm os de retirada (a). À medida que o cliente solicita o produto do supermercado próximo (b), os cartões de retirada acompanham as embalagens (c).

Os kanbans de retirada servem como uma lista de compras. Para cada kanban de retirada será reposta uma embalagem cheia daquele item junto ao cliente. Este trabalho é normalmente feito por um abastecedor. Os kanbans de produção, que acompanhavam as embalagens no estoque fornecedor, serão colocados no quadro (c).

Da mesma forma que no sistema de um cartão, a existência de kanbans de produção no quadro permite, ao processo fornecedor, produzir aqueles itens, nas quantidades determinadas nos cartões (d). Depois de produzidas, as embalagens recebem os kanbans de produção e são colocados novamente no supermercado do fornecedor (e). 
Neste caso, o supermercado pertence ao processo fornecedor, responsável por manter as quantidades de peças para que o cliente sempre seja atendido (f).

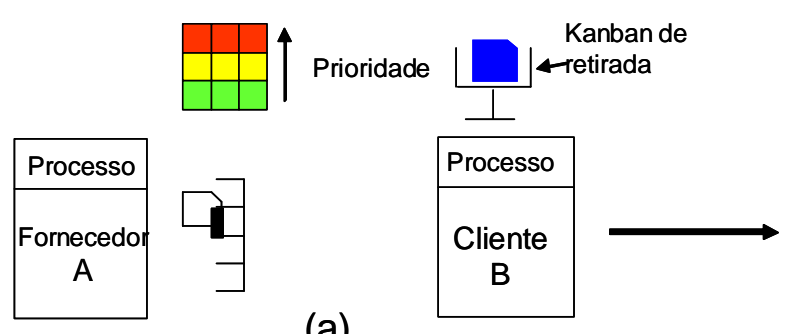

(a)

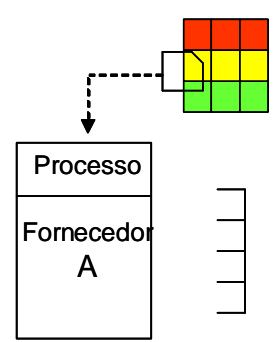

(d)
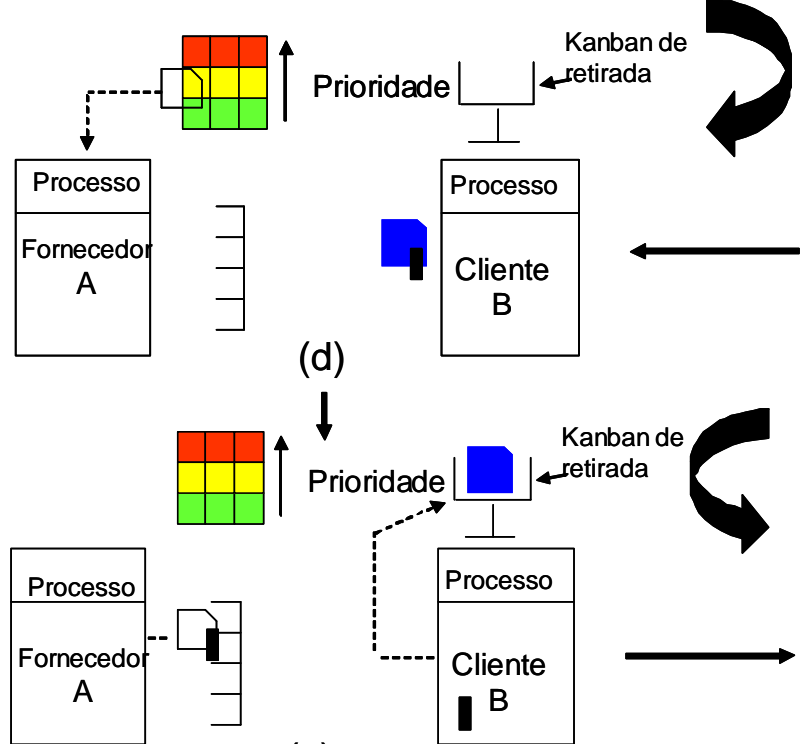

(e)

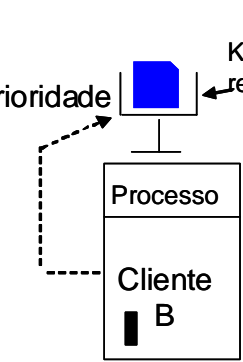

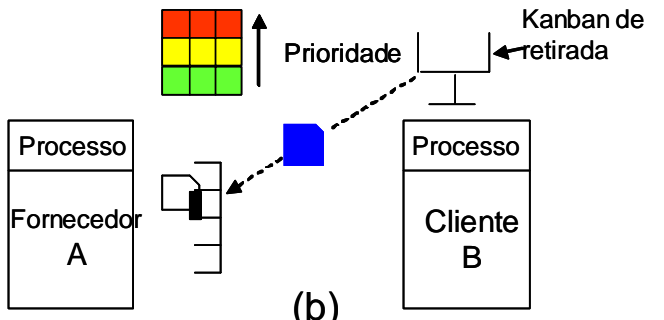

(b)

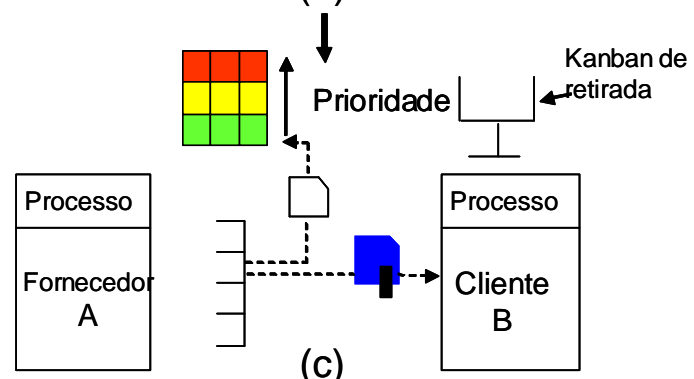

(c)

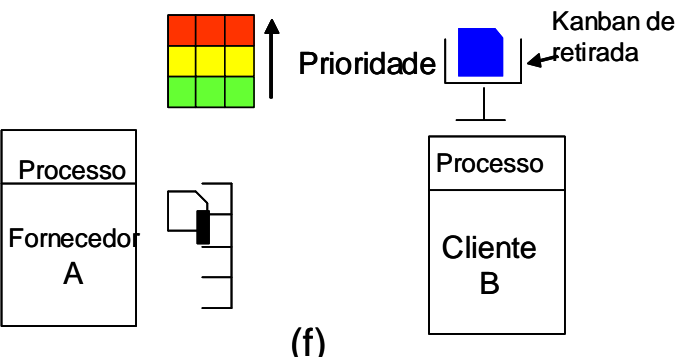

(f)

Figura 10 - Sistema kanban de 2 cartões Fonte - RENTES, 2003

Segundo Corrêa e Gianesi (1993) e Moura (1992) este sistema kanban é o mais difundido, porém o sistema de um cartão é mais simples de ser implementado. É comum implementar o sistema com um cartão e depois evoluir para o de dois cartões.

Sistema kanban de sinal: é um cartão que auxilia o controle de reposição convencional de estoques. Ele é um cartão que fica junto com o material estocado e que é retirado e transportado até o quadro quando o volume de estoque atinge o ponto de reposição. A figura 11 ilustra seu funcionamento, nas etapas (a) e (b) o processo cliente vai consumindo os produtos, até que se atinge o nível mínimo como em (c). A partir neste momento, o kanban de sinal é disparado, indo para o posto de kanban (c), que aciona a produção (d). Quando acaba o processo produtivo, os produtos são repostos (e) e o kanban de sinal fica junto com o material estocado (f). 


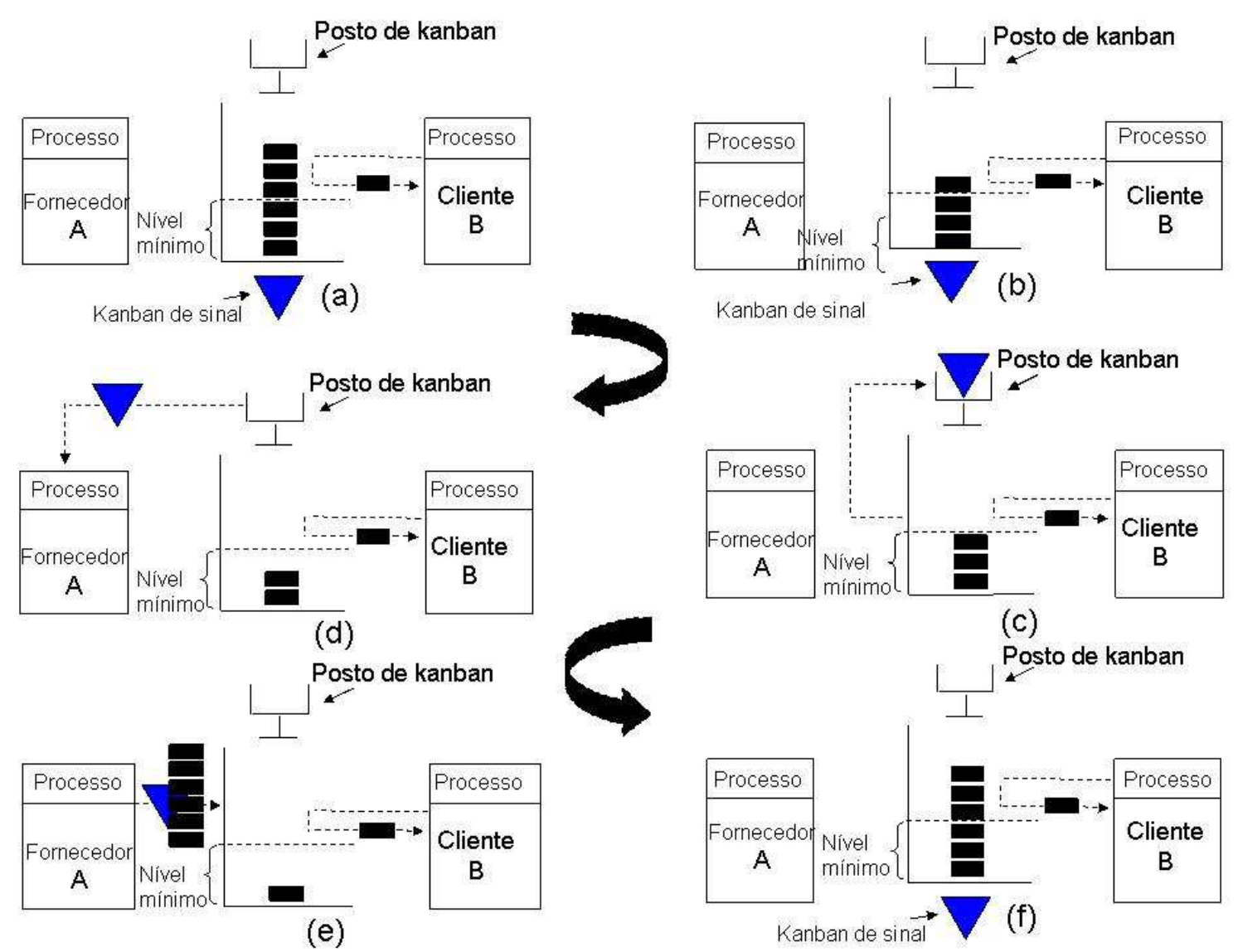

Figura 11 - Sistema kanban de sinal

Fonte - RENTES, 2003

$\mathrm{Na}$ implementação do kanban é preciso dar muita atenção na parte de treinamento do pessoal diretamente envolvido. Mesmo tendo um funcionamento simples, a operacionalização do kanban está fortemente baseada na parte comportamental.

Segundo Moura (1992) o sistema kanban foi desenvolvido para propiciar uma maneira clara de se observar o fluxo de produção e os níveis de work-in-process (WIP), estimulando todos dentro da organização a descobrirem meios para melhorar a produtividade. A participação dos operários é vital para o bom funcionamento do sistema, pois todo o sistema é operado pelos empregados da fábrica.

Shingo (1996a) enumera as principais vantagens dos sistemas kanban:

1. Melhoria total e contínua dos sistemas de produção;

2. Regulagem do fluxo de itens globais com controle visual a fim de executar essas funções com precisão;

3. Simplificação do trabalho administrativo dando autonomia ao chão de fábrica;

4. Informação transmitida de forma organizada e rápida. 


\subsubsection{Heijunka}

O heijunka é o nivelamento da produção, de forma a atender à variação da demanda. Ele é uma programação nivelada através do seqüenciamento de pedidos em um padrão repetitivo e do nivelamento das variações diárias de todos os pedidos para corresponder à demanda no longo prazo. Dito de outra maneira, heijunka é o nivelamento das quantidades e tipos de produtos (GUINATO, 2000).

Segundo Rother e Shook (1998) agrupar os mesmos produtos e produzilos todos de uma só vez dificulta o atendimento da demanda dos clientes que querem algo diferente do lote que está sendo produzido. Além disso, provoca um desbalanceamento na produção dos componentes dos processos anteriores (RENTES, 2003).

A programação da produção através do heijunka permite a combinação de itens diferentes de forma a garantir um fluxo contínuo de produção, nivelando também a demanda dos recursos de produção. O heijunka, da forma como é utilizado na Produção Enxuta, permite a produção em pequenos lotes e a minimização dos inventários.

Para executar o heijunka existe o heijunka box ou quadro de nivelamento da produção. Ele é um instrumento visual desenvolvido pela Toyota, cuja função é ordenar os cartões kanban em função das restrições do processo produtivo, comunicando o ritmo e o mix de produção. Um operador familiarizado com o quadro é capaz de entender o que está acontecendo em seu ambiente de trabalho com uma simples olhada para ele: é possível saber se a produção está atrasada ou não, o que deve ser produzido e quando (BATTAGLIA, 2003).

Um exemplo do quadro Heijunka Box é apresentado na figura 12. 


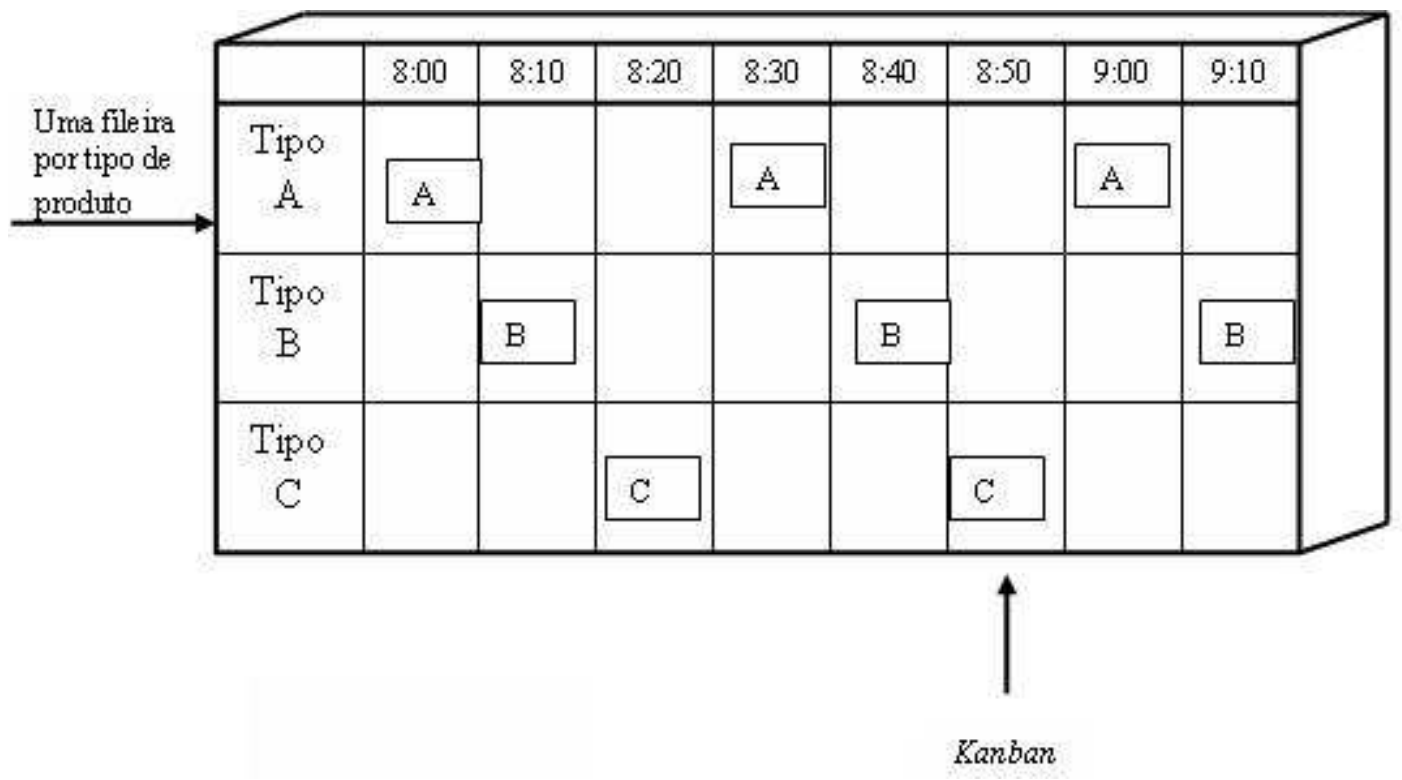

Figura 12 - Quadro de Nivelamento da Carga.

Fonte - Adaptado de ROTHER, M.; SHOOK, J. 1998

No quadro, os tipos de produtos A, B e C estão sendo produzidos alternadamente, através do nivelamento da produção. Neste caso, a produção segue a sequiência $\mathrm{ABCABCAB}$, permitindo a entrega mais rápida de produtos diferentes para $\mathrm{o}$ cliente. Se existir um pedido de somente o produto $\mathrm{C}$, o cliente não precisará esperar ser feito todo o lote A e B.

\subsubsection{Mapa do Fluxo de Valor}

Segundo Rother e Shook (1998) o mapeamento do fluxo de valor é uma ferramenta da Produção Enxuta utilizada para melhor visualizar e entender todo o processo de manufatura de um produto, desde a matéria-prima até a venda do produto acabado e do fluxo de informações.

Através do mapeamento do fluxo de valor é possível identificar os desperdícios no processo produtivo e traçar uma visão futura desse processo, onde todos os problemas detectados serão atacados e corrigidos de forma a garantir a implementação de um fluxo que realmente agregue valor ao produto final.

O fluxo de valor pode ser também entendido como a trilha da produção de um produto, desde o consumidor até o fornecedor (ROTHER e SHOOK, 1998).

Segundo Andrade (2002) as vantagens dessa ferramenta são:

Permitir uma visão ampla de todo o fluxo, e não dos processos isoladamente;

Auxiliar a identificação dos desperdícios considerados pela Produção 
Enxuta;

Mostrar simultaneamente a relação entre os fluxos de materiais e informações;

Fornecer uma linguagem simples e comum para tratar os processos de manufatura;

Tornar as decisões mais visíveis, permitindo uma discussão prévia das possíveis alternativas de melhoria, e;

Formar a base de um plano de ações.

Esta ferramenta segue as etapas mostradas na figura 13.

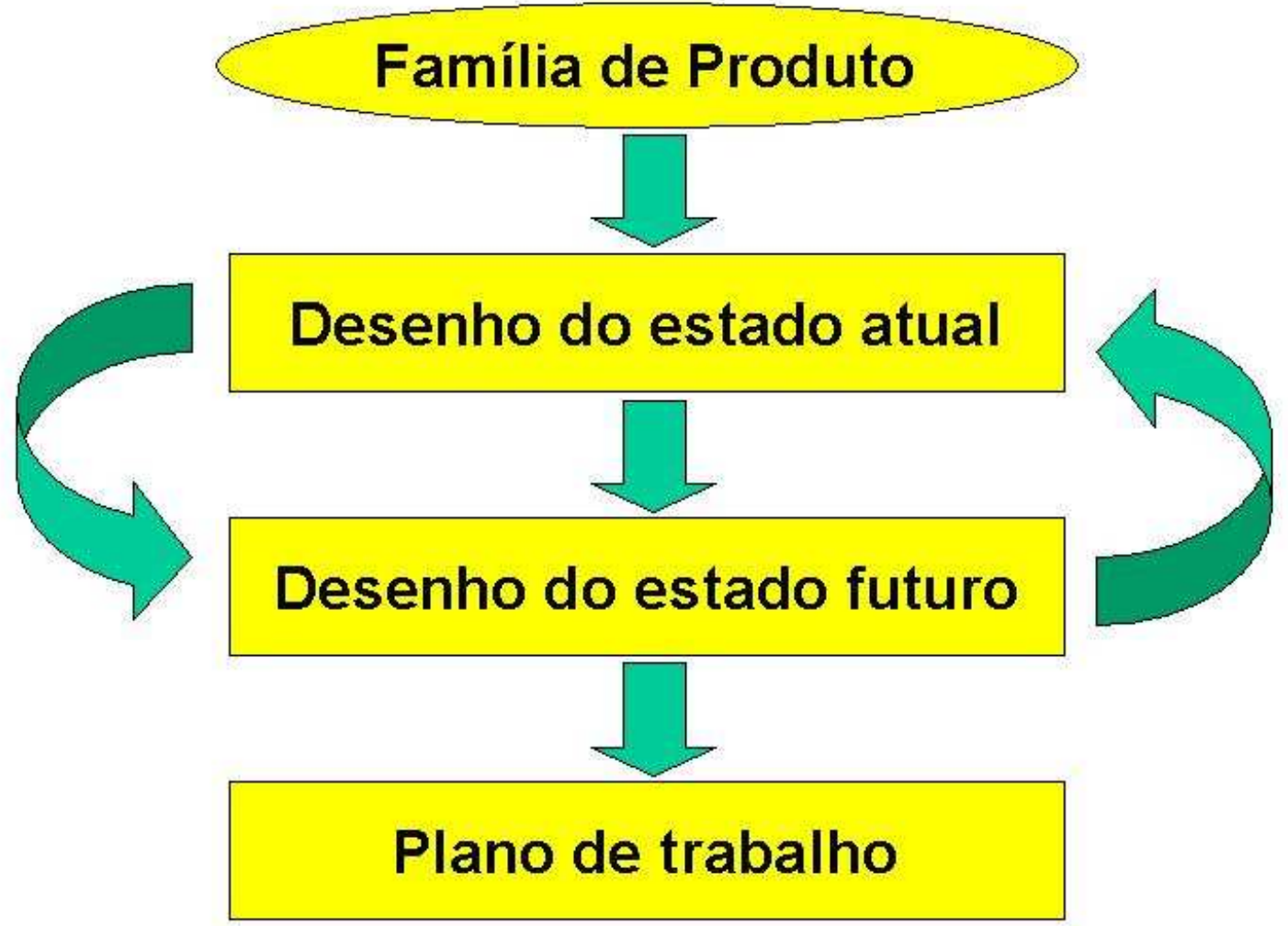

Figura 13 - Etapas do mapeamento do fluxo de valor. Fonte - ROTHER, M.; SHOOK, J. 1998

O primeiro passo é identificar as famílias de itens de acordo com semelhanças de processo, ou seja, produtos que passem por etapas semelhantes de processamento e utilizam equipamentos comuns (ROTHER e SHOOK, 1998). As famílias também se diferenciam pela repetitibilidade e não-repetitibilidade de seus elementos ou pelos clientes segmentados em mercados (RENTES, 2003). 
Deve-se destacar que não é viável fazer uma análise de peça a peça em uma família que contém muitos produtos, já que uma das vantagens desta ferramenta é sua simplicidade que pode ser perdida.

A partir deste momento é possível desenhar o mapa do estado atual, que é feito a partir da coleta de informações no chão de fábrica. Neste desenho é feita a representação visual de cada processo de fluxo de material e informação, utilizando ícones representativos, mostrados na figura 14.

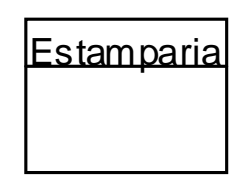

Processo

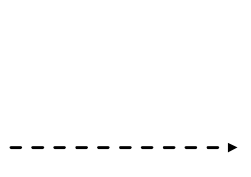

Fecha de

produção

empurrada

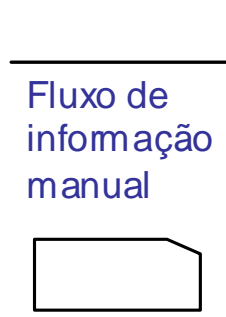

Kanban de produção

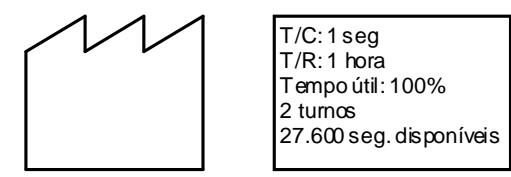

Fornecedor/ Cliente
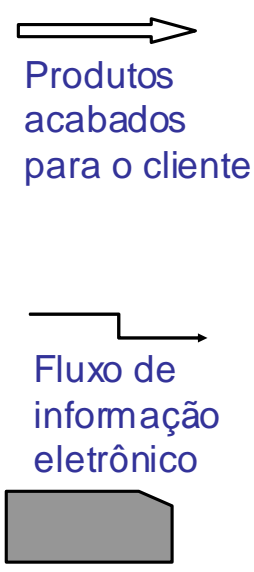

Kanban de transporte
Caixa de dados

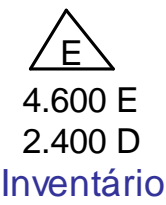

Inventário

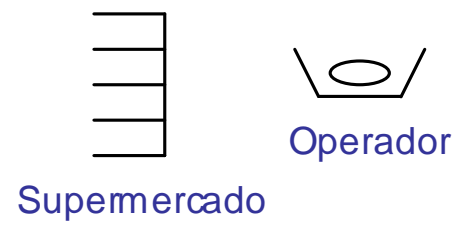

Semanal

Programação

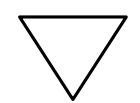

Kanban de sinal

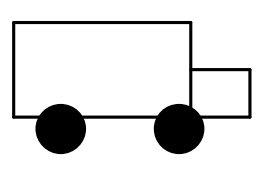

Embarque para caminhão

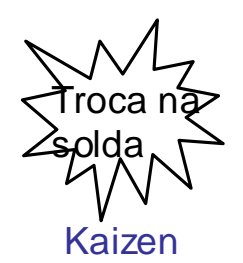

XOXO

Heijunka box

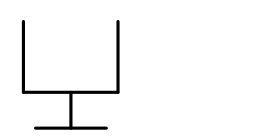

Posto de kanban

Figura 14 - Ícones utilizados no mapa do fluxo de valor.

Fonte - RENTES, 2003 baseado em ROTHER E SHOOK, 1998.

Dois pontos importantes do mapa do fluxo de valor são: a identificação do tempo de agregação de valor, que é o tempo que realmente a empresa está agregando valor no seu produto e do lead time de produção, que é o tempo que uma peça leva para mover-se ao longo de todo um processo ou um fluxo de valor, desde o começo até o fim (ROTHER e SHOOK, 1998).

Um exemplo de mapa do fluxo de valor é apresentado na figura 15. 


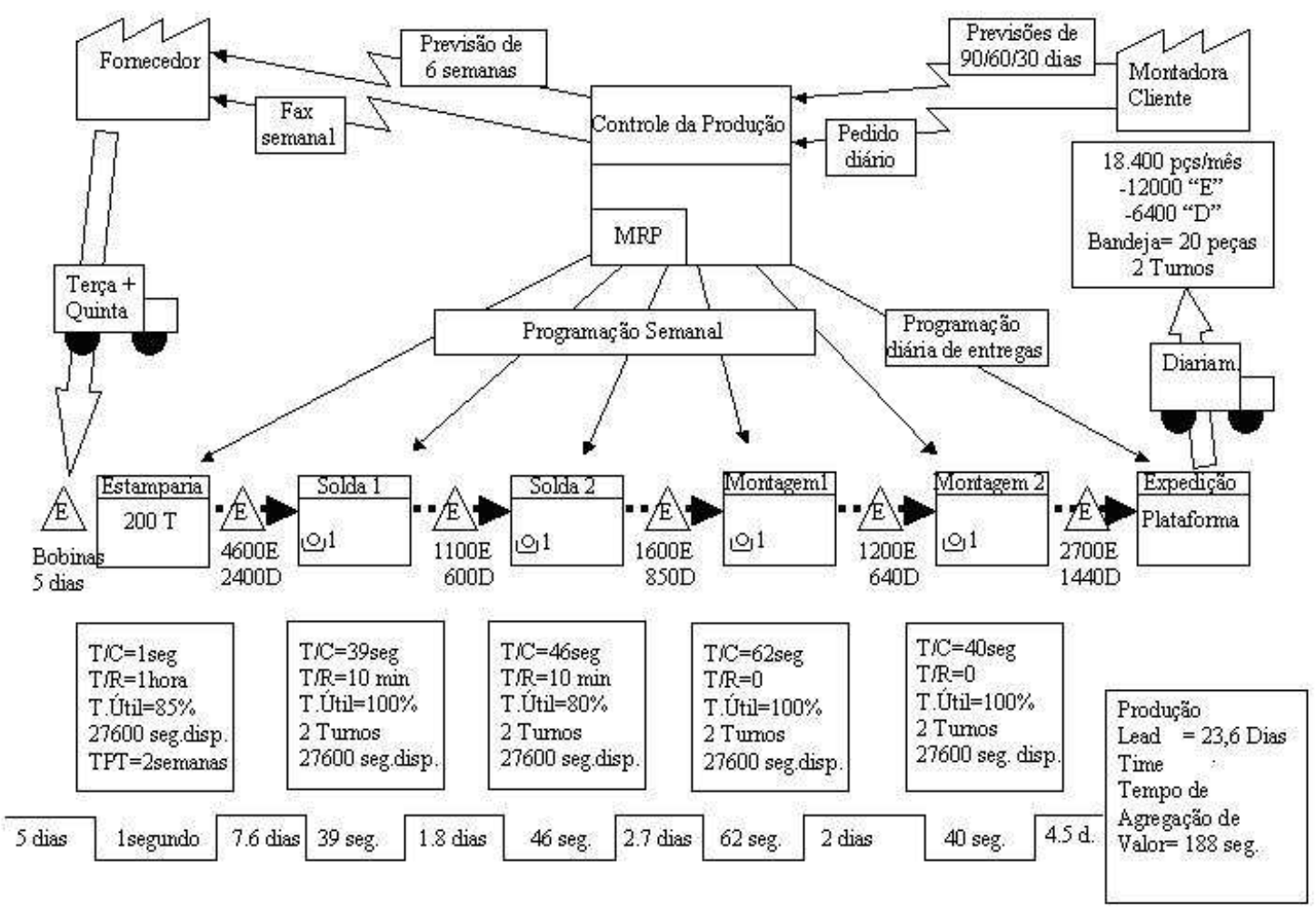

Figura 15 - Mapa do Fluxo de Valor.

Fonte - Adaptado de ROTHER, M.; SHOOK, J. 1998

A seguir é gerado um mapa do estado futuro, ou seja, um modelo no qual a empresa pretende chegar, procurando eliminar os problemas evidenciados e analisados junto ao mapa do estado atual.

O passo final é desenvolver e promover a implantação de um plano de ações, o qual descreva como será realizada a transição do estado atual para o estado futuro.

Segundo Rentes (2003) os passos do plano de ações, para a transição do estado atual para o futuro, devem ser:

Produção orientada para fluxo específico de família de produtos;

Taxa de produção de acordo com as necessidades dos clientes;

Fluxo contínuo sempre que possível;

Redução drástica de inventários;

Produção puxada sempre que fluxo contínuo for impossível;

Layouts com células em U sempre que possível;

Padrão "Montagem mediante ordem" ao invés do padrão "Fabricação por ordem" ou "Montagem para estoque"; 
Trabalhadores multifuncionais e com autonomia para tomada de decisões nas células de produção;

Controle de produção visual; e

Fluxo contínuo ou produção puxada com fornecedores.

É importante lembrar que a participação da alta direção das empresas deve deixar claro para todos os funcionários a prioridade em se alcançar o estudo futuro desenhado, expondo suas expectativas de prazos para implementação e alocação dos recursos necessários (FERRO, 2003).

Depois de implementado o estado futuro, o processo todo se repete, na busca de uma melhoria contínua para o fluxo de valor.

\subsubsection{Manutenção Produtiva Total}

A falta da Manutenção Produtiva Total (MPT) é considerada um dos grandes problemas enfrentados pelas organizações, pois as paradas imprevistas por quebra de máquinas e equipamentos podem gerar grandes prejuízos para as empresas. Estes prejuízos podem ser altos índices de estoques, horas extras para reposição de produção, maior espaço físico para armazenamento de materiais em processo e produtos acabados, mão de obra ociosa para a realização da manutenção dos equipamentos parados, e outros.

Womack e Jones (1998) comentam que para os sistemas de fluxo contínuo fluam são necessários que todos os operários possuam múltiplas habilidades e que as máquinas estejam em condições apropriadas para operarem com precisão quando necessário, para que todas as peças sejam perfeitas, precisando utilizar para isto a MPT.

Segundo Takahashi e Osada (1993), a MPT surgiu no Japão por volta dos anos 70, a partir de um avanço das técnicas e procedimentos tradicionais das manutenções produtivas: corretiva, preventiva e preditiva. Entendem-se como manutenção corretiva aquela em que ocorre primeiro a falha no equipamento e, só então, é feita a manutenção, implicando em perda de produção e danos à máquina. A manutenção preventiva consiste em exercer um controle sobre o equipamento de forma a reduzir a probabilidade de falhas, baseado em intervalos regulares de manutenção. Finalmente, a manutenção preditiva é baseada no acompanhamento das condições do equipamento e como estas condições variam com o tempo. Com isso, ela é programada 
no momento necessário para o equipamento e para o processo produtivo.

A MPT pode ser definida como um conjunto de atividades de manutenção produtiva, direcionadas a cada estágio do ciclo de vida do equipamento. Ela envolve o conjunto de todos os empregados da organização e abrange desde a alta administração até os operários da linha de produção, no sentido de voltarem sua atenção para todos os equipamentos da fábrica. Ela engloba cinco objetivos principais descritos a seguir (TAKAHASHI e OSADA, 1993):

Garantir a eficiência global dos equipamentos;

Estabelecer um sistema completo de manutenção produtiva, para todo o período de vida útil do equipamento;

Ter o apoio de todos os departamentos envolvidos no plano de elevação da capacidade instalada;

Envolver todas as pessoas da organização; e

Incentivar os princípios de trabalho em equipe para consolidar ações de melhoria contínua, participação nos círculos de qualidade e manter a motivação.

Segundo Pinto e Xavier (1998) a MPT busca atingir a quebra-zero ou falha-zero, que é um dos principais fatores de prejuízo do rendimento operacional. A quebra-zero significa que a máquina não pode parar durante o período em que foi programada para operar, diferentemente da condição de a máquina nunca poder parar.

A MPT visando a quebra-zero dos equipamentos, tenta eliminar as 6 grandes perdas, enumeradas por Takahashi e Osada (1993), descritas a seguir:

1. Perda por quebra de máquinas;

2. Perda por mudança de linha e regulagem;

3. Perda por parada temporária;

4. Perda por queda de velocidade;

5. Perda por defeitos e retrabalhos; e

6. Perda para a entrada em operação.

Nakajima apud Antunes Junior (2001) afirma que sem a MPT, o Sistema Toyota de Produção (STP) não pode funcionar, pois ele relaciona estas 6 perdas com as características básicas do sistema. Ao reduzir as perdas por quebras de máquinas e por paradas melhora-se a sincronização da produção, podendo produzir com estoque-zero e com padrões operacionais estabelecidos como tempo de ciclo, seqüência de produção e 
tempos padrões de folgas. Reduzindo as perdas devido a mudanças de linha e entrada em operação (setup), consegue-se diminuir os tamanhos dos lotes de produção e adotar sinais visuais para a solução rápida de problemas. Ao reduzir as perdas por queda de velocidade, os padrões operacionais são mantidos e finalmente com a redução das perdas por defeitos e por retrabalho podem proporcionar a eliminação destes desperdícios tão perseguidos pela Produção Enxuta.

A implementação da MPT deve ser ajustada às características específicas de cada empresa, tais como: tamanho da fábrica, escala do negócio e tipo de produtos. $\mathrm{O}$ ponto fundamental é fazer com que a implementação esteja integrada com outros esforços de melhoria, contribuindo para o aumento de produtividade geral e redução dos custos (TAKAHASHI e OSADA, 1993).

\subsubsection{Administração da Qualidade Total}

A filosofia da Produção Enxuta procura utilizar a capacidade plena dos funcionários, pois a eles é delegada a autoridade para produzir itens de qualidade para atender, em tempo, o próximo passo do processo produtivo.

Segundo Martins (1998) em um sistema de Produção Enxuta, a qualidade é essencial, pois o funcionário tem a autoridade de parar o processo produtivo, se identificar algo que não esteja previsto. Este sistema produtivo facilita em muito a obtenção da qualidade, pois os defeitos são descobertos e soluções são desenvolvidas imediatamente. O sistema é projetado para expor os erros e não os encobrir com os estoques.

A Total Quality Management (TQM) ou Administração da Qualidade Total é uma filosofia, uma forma de pensar e de trabalhar, que se preocupa com o atendimento das necessidades e das expectativas dos consumidores. Tenta mover o foco da qualidade de uma atividade puramente operacional para uma responsabilidade de toda a organização, através de um processo de melhoria contínua. Dedica-se também a redução dos custos da qualidade, em particular dos custos de falhas (MARTINS, 1998).

Para Deming (1986) TQM está baseada em 14 pontos essenciais enumerados a seguir:

1. Criar e publicar uma declaração dos objetivos e propósito da empresa. Este documento deve estar à disposição de todos os funcionários;

2. Todos da empresa devem adotar a nova filosofia;

3. Deixar claro o propósito da inspeção para melhoria dos processos e 
redução dos custos;

4. Acabar com a prática de fazer negócio com base apenas no preço;

5. Melhorar continuamente o sistema de produção e serviços;

6. Instituir o treinamento;

7. Ensinar e instituir a liderança;

8. Acabar com o medo e criar a verdade, buscando o clima para a inovação;

9. Otimizar os esforços;

10. Eliminar slogans e metas para a mão-de-obra que exijam um nível zero de falhas e estabeleça novos níveis de produtividade, pois muitas vezes o problema está no sistema e não nos trabalhadores;

11. Eliminar cotas numéricas na produção, substituindo por liderança;

12. Remover as barreiras ao orgulho e do desempenho do trabalho realizado;

13. Estimular a educação e o auto-aprimoramento a todos; e

14. Concretizar o processo de transformação.

Para Juran (1990) TQM é baseada em três processos: Planejamento da qualidade, que consiste no desenvolvimento de um produto ou processo; Controle da qualidade, que consiste em manter as operações do processo conforme o planejado; e Melhoramento da qualidade, que combate a baixa qualidade e estabelece novos processos de melhoria.

Crosby (1986) relaciona TQM com o defeito zero, já abordado anteriormente, sendo necessário para isto: o comprometimento da gerência; estabelecimento de equipes de melhoria da qualidade; medição, conhecimento, custo de avaliação da qualidade; ação corretiva; programa de defeito zero; treinamento de supervisores; estabelecimento de metas; remoção de causas e erros e fazer melhorias constantes.

Segundo Brassard (1992) existem algumas técnicas e ferramentas que auxiliam a gestão da qualidade nas empresas, dentre elas pode-se destacar as 7 ferramentas da qualidade, descritas a seguir:

Estratificação: é uma ferramenta, na qual os dados são agrupados em grupos ou subgrupos de acordo com características ou categorias como: tempo, local, tipo, sintoma ou outros fatores;

Folha de verificação: ou check-list, é uma planilha na qual são 
documentados os dados levantados de qualidade que se queira controlar. Geralmente é elaborado antes de se utilizar o gráfico de Pareto ou o diagrama de Ishikawa;

Gráfico de Pareto: é um gráfico em forma de barras verticais, que ordena as freqüências das ocorrências, permitindo a priorização e uma boa visualização dos problemas encontrados;

Diagrama de Ishikawa: ou diagrama de causa e efeito, tem por objetivo o mapeamento de um processo através de uma série de fenômenos que tem entre eles uma relação de causa e efeito;

Diagrama de correlação: é um gráfico no qual são mostradas as relações de duas variáveis quantitativas, verificando se há uma relação entre as causas e em que intensidade;

Histograma: é um gráfico de barras que representa a distribuição de uma determinada população, analisando a variação existente entre ela; e

Carta de controle: é um gráfico no qual um processo é analisado, mostrando se está ou não sob controle. Baseado em dados de amostragem, ela examina se um processo não está se comportando como preestabelecido, e buscando a causa da variação.

A Produção Enxuta também engloba outras práticas, mas para esta pesquisa, estas apresentadas na tabela 2, foram priorizadas, devido à importância de cada uma delas dentro deste processo. Através do levantamento destas práticas pôde-se obter um cenário das implementações da Produção Enxuta nas empresas estudadas, verificando quais foram implementadas e os resultados gerados.

Tabela 2 - Práticas de Produção Enxuta

\begin{tabular}{|c|}
\hline Práticas de Produção Enxuta consideradas na \\
pesquisa \\
\hline $5 \mathrm{~S}$ \\
Padronização do Trabalho \\
Layout celular \\
Kanban \\
Heijunka box \\
Mapa do Fluxo de Valor \\
Manutenção Produtiva Total \\
Administração da Qualidade Total \\
\hline
\end{tabular}




\subsection{Estratégias de implementação}

Para que a Produção Enxuta seja implantada, a empresa deve escolher uma estratégia de implementação mais adequada para a sua realidade, buscando conciliação com os objetivos que se pretende alcançar. A estratégia escolhida deve ser definida antes do início da implementação e a partir da sua definição, as pessoas responsáveis pelo projeto devem montar um plano estruturado com as ações que serão necessárias.

Existem algumas estratégias de implementação de projetos que podem ser escolhidas quando a empresa opta por utilizar a Produção Enxuta.

De acordo com Rentes (2003), há três principais estratégias de implementações utilizadas em projetos de Produção Enxuta. São elas:

$>$ Implementação piloto, que é aquela feita primeiramente em uma famíliapiloto de produtos, na qual são executados todos os testes e em um segundo momento, a implementação pode expandir para outras famílias de produtos, chegando ou não a sua totalidade.

$>$ Implementação programática, que é aquela realizada na empresa toda de forma extensiva, exigindo o treinamento de todos os funcionários e o projeto demora mais a dar resultados (cerca de 2 anos) e,

Implementação prototipal, na qual são selecionadas poucas famílias de produtos e o foco está na obtenção de resultados em curto espaço de tempo, cerca de 3 a 6 meses, com renovação do projeto após este ciclo.

\subsection{Considerações finais}

A Produção Enxuta, como filosofia de negócios, está baseada na identificação dos desperdícios e do valor a partir da ótica dos clientes e usuários, envolvendo a criação de fluxos contínuos e sistemas puxados pela demanda real dos clientes.

Através da implementação de suas práticas, as empresas podem obter bons resultados, como foram descritos anteriormente no trabalho. O que cabe ressaltar é que a Produção Enxuta exige um comprometimento por parte da empresa para que ela alcance os resultados esperados. Ferro (2004) explica que é importante que as empresas tornem a Produção Enxuta uma cultura empresarial a ser seguida. 


\section{Capítulo 3 - Procedimentos Metodológicos da Pesquisa}

\subsection{Caracterização da pesquisa}

Para conseguir alcançar os objetivos deste estudo, a pesquisa utilizou um procedimento metodológico, que incluiu: o levantamento das empresas, definição de um roteiro de entrevistas, coleta de informações utilizando este roteiro e análise dos dados coletados. O roteiro de entrevistas foi elaborado a partir de um levantamento bibliográfico feito previamente.

Segundo Botomé (1997) o método de pesquisa não visa limitar as possibilidades de ação, mas serve como uma ferramenta que orienta e auxilia o pesquisador nas suas decisões para o processo de geração do conhecimento. A pesquisa é empreendida metodologicamente, a partir de um problema para o qual se procura uma compreensão apropriada, de forma científica, podendo ser descritiva, aplicada ou teórica. No caso desta pesquisa, sendo uma observação e análise de casos, a pesquisa é de natureza descritiva.

Para Cervo e Bervian (1996) a pesquisa descritiva observa, registra, analisa e correlaciona fatos e fenômenos sem manipulá-los, buscando descobrir sua frequiência e relação com outros. O problema observado neste trabalho é o entendimento de como ocorreu o processo de Produção Enxuta nas empresas escolhidas.

A pesquisa descritiva pode assumir diversas formas, destacando o estudo exploratório. Os estudos exploratórios têm por objetivo buscar maiores informações sobre determinado assunto de estudo. Seu objetivo é a familiarização com o fenômeno ou obter uma nova percepção do mesmo e descobrir diferentes enfoques ou idéias (CERVO E BERVIAN, 1996). No caso deste trabalho, procurou-se fazer um estudo comparativo, observando diferentes enfoques de implantação de Produção Enxuta.

Segundo Gil (1991) a pesquisa exploratória envolve um levantamento bibliográfico, entrevistas com pessoas que tiveram experiências práticas com o problema pesquisado e análise de exemplos que estimulem a compreensão do problema, 
sendo dois procedimentos técnicos assumidos: pesquisas bibliográficas e estudos de caso. No caso desta pesquisa, foram realizados ambos os procedimentos. Uma pesquisa bibliográfica foi feita para a busca do conhecimento sobre o assunto, além da identificação de casos de implantação. Para identificar as práticas comumente utilizadas nas aplicações de Produção Enxuta, foi feito o roteiro de entrevistas. Segundo Yin (1981), o estudo de caso se caracteriza como sendo uma estratégia de pesquisa, que busca examinar um fenômeno contemporâneo dentro do seu contexto. Ela pode ser, segundo Stake (1994), realizada na forma de um estudo único ou múltiplo. A aplicação de Produção Enxuta é um fenômeno contemporâneo cujo funcionamento em setores específicos, como o de fabricação de máquinas e implementos agrícolas, pode ser devidamente avaliado através de observações in loco de diversas situações, caracterizando um estudo multicasos. Neste trabalho, foram estudados nove casos de aplicação, utilizando-se o roteiro de entrevistas como base para a coleta de informações.

A pesquisa foi desenvolvida de forma exploratória, que segundo Roesch (1999), visa levantar questões e hipóteses para futuros estudos, por meio de dados qualitativos.

Sendo assim, este estudo pode ser caracterizado como uma pesquisa descritiva qualitativa, com caráter exploratório, utilizando múltiplos estudos de casos.

\subsection{As perguntas da pesquisa}

As perguntas da pesquisa fazem parte da delimitação do problema do trabalho, servindo para orientá-lo e norteá-lo. As questões da pesquisa são, o que, de fato, o pesquisador pretende esclarecer e elas se baseiam nas idéias propostas na formulação do problema e nos objetivos da investigação (TRIVIÑOS, 1987).

Para tanto, as questões que nortearão este trabalho são:

A Produção Enxuta vem sendo conduzida de forma estruturada, ou seja, existem investimentos e metodologia para a implementação deste processo produtivo por parte das empresas de máquinas e implementos agrícolas?

Quais as práticas de Produção Enxuta que vêm sendo utilizadas por essas empresas?

Quais os resultados observados nas empresas estudadas?

Através dessas perguntas, busca-se um levantamento do uso das práticas 
de Produção Enxuta em empresas da indústria nacional de máquinas e implementos agrícolas, identificando-se os principais fatores motivadores à implementação, os investimentos necessários, a metodologia e práticas adotadas, os principais problemas encontrados e as mudanças ocorridas pela implementação.

\subsection{Passos dos procedimentos metodológicos}

A presente pesquisa utilizou os seguintes passos metodológicos, mostrados anteriormente na figura 2 , e descritos a seguir.

\subsubsection{Pesquisa bibliográfica}

O primeiro passo desenvolvido foi o levantamento bibliográfico. Nesta pesquisa foram identificadas as principais abordagens teóricas associadas ao tema e o conjunto de práticas comumente adotadas pelas empresas praticantes da Produção Enxuta. Para isso foi utilizado material bibliográfico e científico como: livros, sites na internet, artigos de revistas, jornais especializados e dissertações. O resultado desta pesquisa bibliográfica é apresentado no capítulo 2 .

\subsubsection{Roteiro de entrevista}

Esta fase da pesquisa foi conduzida juntamente com o próximo item, identificação de empresas com aplicação de Produção Enxuta. Nesta fase foi elaborado um roteiro de entrevista a partir dos elementos teóricos apresentados no capítulo 2, e foi caracterizada com o desenvolvimento de um roteiro de entrevista, visando responder as questões da pesquisa. O roteiro final compreende cinco partes, onde são apresentados respectivamente um histórico da aplicação, desenvolvimento e implementação, práticas utilizadas na empresa, resultados obtidos e comentários finais. O desenvolvimento deste roteiro é apresentado mais detalhadamente no capítulo 4.

\subsubsection{Identificação de empresas com aplicação de Produção Enxuta}

O principal critério de escolha do setor e das empresas a serem estudadas foi a importância que o setor agrícola brasileiro vem obtendo tanto no que diz respeito ao mercado interno quanto no mercado externo. Este crescimento real e o potencial de crescimento ainda não realizado é tema de pesquisas recentes mundiais (USDA, 2003). O setor de máquinas e implementos agrícolas obviamente acompanha esta evolução e 
necessita de estudos que possam contribuir para o aperfeiçoamento dos seus processos produtivos, melhorando seu desempenho frente ao mercado nacional e internacional.

A partir de estudos que vêm sendo realizados pelo grupo GMMO (Gerenciamento da Mudança e Melhoria Organizacional), do Departamento de Engenharia da Produção da Escola de Engenharia de São Carlos-USP, foram identificadas algumas empresas que estão aplicando os conceitos de Produção Enxuta e dentre delas foram escolhidas nove empresas para a realização deste estudo, sendo oito delas localizadas no Estado de São Paulo e uma no Estado do Paraná.

Estas empresas foram selecionadas por apresentarem seus casos em eventos de Produção Enxuta, como o Lean Summit 2002 e os Fórum ABIMAQ-CSMIA (Câmaras Setoriais de Máquinas e Implementos Agrícolas) 2003 e 2004.

\subsubsection{Visitas às empresas e realização das entrevistas}

Após a identificação e escolha das empresas, elas foram contactadas e foi feito um agendamento de visitas e entrevistas para o levantamento das informações necessárias.

Essas visitas e entrevistas seguiram o agendamento abaixo, mostrado no quadro 1.

Quadro 1- Visitas nas empresas

\begin{tabular}{|c|c|}
\hline \multicolumn{2}{|c|}{ Visitas nas empresas } \\
\hline Empresas & Data das visitas \\
\hline A & $7 / 4 / 2005$ \\
B & $17 / 3 / 2005$ \\
C & $14 / 4 / 2005$ \\
D & $4 / 3 / 2005$ \\
E & $22 / 2 / 2005$ \\
F & $9 / 3 / 2005$ \\
G & $28 / 4 / 2005$ \\
H & $10 / 5 / 2005$ \\
I & $20 / 4 / 2005$ \\
\hline
\end{tabular}

Nos dias agendados foram aplicados os roteiros de entrevistas no(s) principal(is) responsável(is) pelo projeto Lean em cada empresa. As entrevistas foram gravadas e posteriormente transcritas. Os roteiros de entrevista devidamente preenchidos estão apresentados nos apêndices A a I.

A apresentação das respostas obtidas é detalhada no capítulo 4. 


\subsubsection{Análise dos dados coletados}

Após a aplicação do roteiro de entrevista foi feita uma análise dos dados levantados. Esta análise foi realizada com a finalidade de responder às questões propostas por esta pesquisa. Desta forma foi analisado se a empresa utiliza os conceitos da Produção Enxuta nos seus processos produtivos e como se deu essa implementação. Além disso, foram identificados os principais fatores motivadores para a mudança, as dificuldades enfrentadas e os resultados obtidos até o momento.

Estas análises estão apresentadas no capítulo 5 deste trabalho.

\subsubsection{Conclusões sobre o estado das aplicações e recomendações para o setor}

A partir das análises são extraídas as principais conclusões sobre o tema. Estas conclusões e recomendações são apresentadas no final do capítulo 5 e contribuem para a divulgação deste sistema produtivo em empresas brasileiras. 


\section{Capítulo 4 - Desenvolvimento e APReSEnTAÇão dos Estudos de Casos}

\subsection{Desenvolvimento dos estudos de caso}

Neste tópico será apresentado o desenvolvimento do roteiro de entrevistas utilizado no levantamento de informações dos casos estudados. Segundo Demo (2001) o roteiro de entrevista pode ter questões abertas e fechadas, dependendo da ênfase que o pesquisador queira dar a um determinado assunto. Neste caso foram utilizadas as duas formas de questões.

A elaboração do roteiro de entrevistas teve como base o referencial teórico, apresentado no capítulo 2 deste trabalho. Seu desenvolvimento considerou os objetivos gerais e específicos do estudo.

O roteiro de entrevistas é apresentado como um guia de entrevistas e está dividido em cinco partes, descritas a seguir.

A primeira parte teve como função fornecer, primeiramente, os dados cadastrais da empresa estudada e traçar um contexto de como a mesma começou a utilizar a Produção Enxuta. Além de abordar o estado atual da empresa frente aos concorrentes, foram também questionados os fatores motivadores para a mudança, os agentes de mudança e se houve participação de agentes externos, como, por exemplo, a contratação de consultoria.

Esta primeira parte está sendo mostrada no quadro 2. 
Quadro 2 - Primeira parte do roteiro de entrevista

Data: / / 2005

Nome da empresa:

Ramo de atividade:

Produtos:

Faturamento:

Principais clientes:

Principais concorrentes:

Número de funcionários:

Entrevistado:

Cargo:

\section{Histórico}

1.1) Quando e por que a empresa começou a utilizar a Produção Enxuta?

1.2) Qual sua participação no mercado consumidor naquele momento?

1.3) Os fatores motivadores para a mudança foram internos ou externos? Quais foram? Explique.

1.4) Qual(is) foi(ram) o(s) principal(is) agente(s) de mudança?

1.5) Houve ajuda de terceiros, como consultoria?

( ) Sim. Como a empresa entrou em contato? Qual a razão da escolha?

( ) Não. Como se deu a mudança internamente? Qual(is) o(s) método(s) utilizado?

Após esta primeira abordagem, inicia-se a segunda parte que trata do desenvolvimento e implementação do projeto de Produção Enxuta. Nesta parte a pesquisa bibliográfica serviu como orientação para a formulação da maioria das questões, com incidência de perguntas abertas e fechadas, de acordo com a relevância do assunto.

Foram feitas perguntas a respeito da estratégia utilizada de implementação (piloto, programática e prototipal), quais medidas tomadas quando começou a implementação do projeto, quais e quantos funcionários foram envolvidos, 
quais os principais problemas encontrados no projeto e na implementação e qual o investimento estimado na implementação. Além de também abordar se houveram mudanças: no sistema de custeio, na medição de desempenho de máquina por operador, desempenho de setup e takt time. A segunda parte está apresentada no quadro 3.

Quadro 3 - Segunda parte do roteiro de entrevista

\section{Desenvolvimento e Implementação}

2.1) Qual a estratégia de implementação adotada?

( ) Implementação Piloto

( ) Implementação Programática

( ) Implementação Prototipal

2.2) Qual(is) foi(ram) a(s) principal(is) medida(s) tomada(s) quando começou a implementação da Produção Enxuta?

2.3) Quais e quantos funcionários foram envolvidos na implementação?

2.4) Quais foram os principais problemas encontrados no projeto e na implementação?

2.5) Qual o investimento estimado na implementação da Produção Enxuta?

2.6) O sistema de custeio dos produtos e do gerenciamento dos custos da empresa foi afetado pelo projeto de Produção Enxuta?

2.7) Após a implementação da Produção Enxuta, a empresa precisou modificar sua medida de desempenho de produção de máquinas/ operador?

2.8) A empresa utilizava algum sistema de medição de desempenho para setup? Após a implementação da Produção Enxuta este sistema foi alterado?

2.9) Qual era o takt time da operação antes da implementação da Produção Enxuta e qual é o atual?

Após este levantamento, inicia-se a terceira parte do roteiro, com o levantamento das práticas de Produção Enxuta, consideradas nesta pesquisa.

Para isso, foi utilizada a Escala de Likert, a qual requer que o respondente indique seu grau de concordância ou discordância em relação a uma série de afirmações relacionadas à atitude ou objeto. Ela consiste em uma parte de itens, composta de afirmações a respeito de um determinado produto, evento ou atitude e outra parte avaliativa, composta de uma lista de categoria de respostas (AAKER, KUMAR e DAY, 2001). O quadro 4 mostra como estão dispostas as afirmações sobre as práticas de Produção Enxuta. 
Quadro 4 - Terceira parte do roteiro de entrevista

\begin{tabular}{|c|c|c|c|c|c|c|c|c|c|c|}
\hline 3) Práticas & 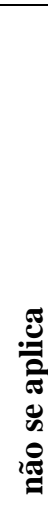 & 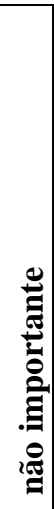 & 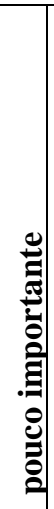 & & 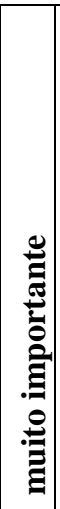 & 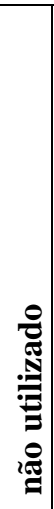 & & 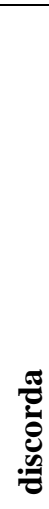 & 葛 & 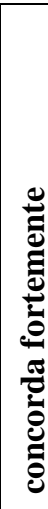 \\
\hline $\begin{array}{l}\text { 3.1)Quanto a utilização dos } 5 \mathrm{~S} \text {, pode-se afirmar que trouxe impactos } \\
\text { significativos para a empresa quanto a melhoria no ambiente de } \\
\text { trabalho. }\end{array}$ & 0 & 1 & 2 & 3 & 4 & 0 & 1 & 2 & 3 & 4 \\
\hline $\begin{array}{l}\text { 3.2) O 5S serviu de elemento inicial para a implementação base para a } \\
\text { disseminação dos conceitos da Produção Enxuta na empresa. }\end{array}$ & 0 & 1 & 2 & 3 & 4 & 0 & 1 & 2 & 3 & 4 \\
\hline $\begin{array}{l}\text { 3.3) A padronização do trabalho contribuiu para melhor utilização dos } \\
\text { recursos da empresa. }\end{array}$ & 0 & 1 & 2 & 3 & 4 & 0 & 1 & 2 & 3 & 4 \\
\hline $\begin{array}{l}\text { 3.4) A padronização do trabalho foi implementada extensivamente na } \\
\text { empresa. }\end{array}$ & 0 & 1 & 2 & 3 & 4 & 0 & 1 & 2 & 3 & 4 \\
\hline $\begin{array}{l}\text { 3.5) A utilização do Layout celular trouxe grandes mudanças no chão } \\
\text { de fábrica quanto a disposição das máquinas e equipamentos. }\end{array}$ & 0 & 1 & 2 & 3 & 4 & 0 & 1 & 2 & 3 & 4 \\
\hline 3.6) O Layout celular foi utilizado extensivamente na empresa. & 0 & 1 & 2 & 3 & 4 & 0 & 1 & 2 & 3 & 4 \\
\hline $\begin{array}{l}\text { 3.7) A utilização do Kanban trouxe agilidade nos processos produtivos } \\
\text { quanto à necessidade de material ou de informações. }\end{array}$ & 0 & 1 & 2 & 3 & 4 & 0 & 1 & 2 & 3 & 4 \\
\hline 3.8) O Kanban foi utilizado extensivamente na empresa. & 0 & 1 & 2 & 3 & 4 & 0 & 1 & 2 & 3 & 4 \\
\hline $\begin{array}{l}\text { 3.9) A utilização do Heijunka box ou o nivelamento de produção trouxe } \\
\text { maior flexibilização e precisão na produção através de ajustes e } \\
\text { reprogramação dos operadores. }\end{array}$ & 0 & 1 & 2 & 3 & 4 & 0 & 1 & 2 & 3 & 4 \\
\hline $\begin{array}{l}\text { 3.10) A utilização do Mapa do Fluxo de Valor conseguiu-se visualizar } \\
\text { e entender melhor os processos produtivos. }\end{array}$ & 0 & 1 & 2 & 3 & 4 & 0 & 1 & 2 & 3 & 4 \\
\hline $\begin{array}{l}\text { 3.11) Com a utilização do Mapa do Fluxo de Valor, a empresa } \\
\text { conseguiu tomar as melhores decisões e seguir um plano de ações } \\
\text { estruturadas. }\end{array}$ & 0 & 1 & 2 & 3 & 4 & 0 & 1 & 2 & 3 & 4 \\
\hline $\begin{array}{l}\text { 3.12) A utilização da Manutenção Produtiva Total trouxe diminuição } \\
\text { nas paradas imprevistas de máquinas, facilitando atingir as metas de } \\
\text { produção. }\end{array}$ & 0 & 1 & 2 & 3 & 4 & 0 & 1 & 2 & 3 & 4 \\
\hline $\begin{array}{l}\text { 3.13) Com a utilização da Administração da Qualidade Total, os } \\
\text { funcionários criaram um senso de responsabilidade e autoridade quanto } \\
\text { à produção. }\end{array}$ & 0 & 1 & 2 & 3 & 4 & 0 & 1 & 2 & 3 & 4 \\
\hline $\begin{array}{l}\text { 3.14) A Administração da Qualidade Total trouxe para a empresa } \\
\text { redução nos custos da qualidade. }\end{array}$ & 0 & 1 & 2 & 3 & 4 & 0 & 1 & 2 & 3 & 4 \\
\hline
\end{tabular}

Quanto à importância, sua pontuação variou de 0 a 4, sendo que quando se assinalou o 0 , o entrevistado não tinha conhecimento do que se tratava ou tinha 
pouco conhecimento sobre o assunto e não saberia responder a sua real importância no projeto Lean, desenvolvido na empresa que ele participou. A pontuação 1 foi obtida quando o entrevistado afirmou que determinada afirmação não era importante para o projeto. Assinalando 2, como pontuação, o entrevistado admitiu que tal afirmação fosse pouco importante no projeto. Já a partir da pontuação 3, o entrevistado admitiu a importância daquela afirmação, sendo que quando ele a julgou muito importante para o projeto, foi assinado 4.

Para a aplicação das práticas de Produção Enxuta, nas empresas estudadas, utilizou-se a mesma pontuação de 0 a 4 , porém para o número 0 foi admitido a não utilização. Para 1 e 2, o entrevistado discordava da afirmação, sendo que 1 era para salientar que discordava fortemente, em relação à implementação do projeto. E os números 3 e 4 eram referentes a concordância com a afirmação, mas 4 foi utilizado para quando o entrevistado concordava fortemente.

$\mathrm{Na}$ quarta parte foram tratados os resultados obtidos através da implementação da Produção Enxuta, levando em consideração diversos aspectos, como pode ser visto no quadro 5 a seguir.

Nesta parte também foi utilizada a Escala de Likert, com a pontuação variando de 0 a 4, sendo que quando foi assinalado 0 , o entrevistado estava admitindo que aquele resultado não tivesse sido medido, até aquele momento. Quando se assinalou 1 ou 2, o entrevistado estava discordando da afirmação, no caso de assinalar 1, a discordância era fortemente. As pontuações 3 e 4 foram assinaladas quando o entrevistado concordava com a afirmação, mas no caso do 4, a concordância era fortemente.

O roteiro dos resultados obtidos é mostrado no quadro5. 
Quadro 5 - Quarta parte do roteiro de entrevista

Quanto aos resultados obtidos devido ao uso Produção Enxuta,
a empresa:

4.1) Conseguiu melhorar sua produtividade em relação à produção/recursos/tempo.

4.2) Conseguiu melhorar o atendimento no prazo do pedido de seus clientes, ou seja, melhorou a pontualidade de entrega.

4.3) Conseguiu reduzir o lead time de fabricação.

4.4) Conseguiu reduzir os custos de fabricação.

4.5) Aumentou o faturamento.

4.6) Aumentou a lucratividade.

4.7) Diminuiu os estoques de matéria-prima.

4.8) Diminuiu os estoques de material em processo.

4.9) Diminuiu os estoques de produto acabado.

4.10) Conseguiu reduzir a área de produção, por causa de rearranjos no layout do chão de fábrica.

4.11) Conseguiu reduzir a movimentação de material e pessoas.

4.12) Conseguiu aumentar sua participação no mercado consumidor.

4.13) Percebeu mudanças culturais em seus funcionários e no ambiente de trabalho.

4.14) Influenciou significativamente a política de vendas/ marketing.

4.15) Mudou a política de desenvolvimento do produto.

4.16) Aumentou a qualidade de seus produtos.

4.17) Aumentou o mix de produtos.

4.18) Conseguiu influenciar seus fornecedores quanto à forma de entrega de material.

4.19) Aumentou o número de fornecedores.

4.20) Diminuiu o número de fornecedores.

4.21) Alterou seu fluxo de informações.

\begin{tabular}{|c|c|c|c|c|}
\hline 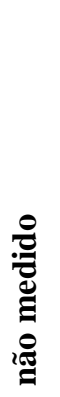 & 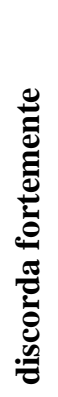 & 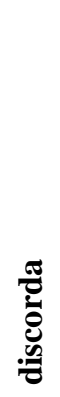 & 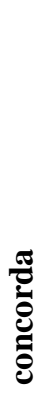 & 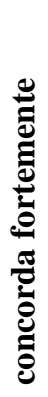 \\
\hline 0 & 1 & 2 & 3 & 4 \\
\hline 0 & 1 & 2 & 3 & 4 \\
\hline 0 & 1 & 2 & 3 & 4 \\
\hline 0 & 1 & 2 & 3 & 4 \\
\hline 0 & 1 & 2 & 3 & 4 \\
\hline 0 & 1 & 2 & 3 & 4 \\
\hline 0 & 1 & 2 & 3 & 4 \\
\hline 0 & 1 & 2 & 3 & 4 \\
\hline 0 & 1 & 2 & 3 & 4 \\
\hline 0 & 1 & 2 & 3 & 4 \\
\hline 0 & 1 & 2 & 3 & 4 \\
\hline 0 & 1 & 2 & 3 & 4 \\
\hline 0 & 1 & 2 & 3 & 4 \\
\hline 0 & 1 & 2 & 3 & 4 \\
\hline 0 & 1 & 2 & 3 & 4 \\
\hline 0 & 1 & 2 & 3 & 4 \\
\hline 0 & 1 & 2 & 3 & 4 \\
\hline 0 & 1 & 2 & 3 & 4 \\
\hline 0 & 1 & 2 & 3 & 4 \\
\hline 0 & 1 & 2 & 3 & 4 \\
\hline 0 & 1 & 2 & 3 & 4 \\
\hline
\end{tabular}

$\mathrm{Na}$ quinta parte foram feitos os comentários finais referentes ao projeto, como: a continuidade ou não da utilização da Produção Enxuta, se a empresa considera que os resultados positivos obtidos podem ser somente atribuídos a Produção Enxuta, quais vantagens e desvantagens encontradas no projeto e comentários livres finais dos entrevistados.

Esta parte está apresentada no quadro 6. 
Quadro 6 - Quinta parte do roteiro de entrevista

\section{Comentários finais.}

5.1) A empresa continua utilizando a Produção Enxuta?

5.2) A empresa atribui os resultados positivos obtidos somente à implementação da Produção Enxuta? Comente.

5.3) Quais outras vantagens encontradas na Produção Enxuta ainda não abordadas neste roteiro de entrevista?

5.4) Quais outras desvantagens encontradas na Produção Enxuta ainda não abordadas neste roteiro de entrevista?

5.5) Faça um comentário sobre um aspecto relacionado a esse assunto e que, possivelmente, não foi abordado (Se sentir necessidade).

Obrigada pela sua colaboração!

Após a elaboração do roteiro de entrevista, foram feitas as visitas e com a aplicação dos mesmos para a finalidade de coletar as informações necessárias à pesquisa. Estas informações estão apresentadas a seguir.

\subsection{Apresentação das empresas estudadas}

Nesta parte será apresentado um breve descritivo sobre as empresas: sua localização, sua fundação, seus produtos, faturamento e número de funcionários. Também serão abordados seus principais clientes e concorrentes, e o dia da visita e entrevistas realizadas.

Posteriormente serão descritos os projetos Lean, assim chamados nesta pesquisa, mostrando seu histórico, desenvolvimento e implementação, as práticas utilizadas e os resultados obtidos de cada empresa separadamente.

\subsubsection{A empresa A}

A empresa A está localizada na cidade de Batatais-SP e foi fundada em 1975. Atua no ramo de máquinas agrícolas, produzindo distribuidores de fertilizantes e corretivos de solo, roçadeiras e desintegradores de cultura.

No ano de 2004, seu faturamento foi aproximadamente $\mathrm{R} \$ 4$ milhões anuais, empregando cerca de 120 funcionários.

Esta empresa em 2000 fez uma parceria com a empresa E, fabricando 
seus produtos com o nome da última e ganhando royalties com isso. Além disso, ela é também produtora de algumas peças que são utilizadas nas máquinas produzidas por E. Sendo assim, a empresa E é o seu principal cliente.

Como seus produtos têm uma acentuada sazonalidade, pois se tratam de máquinas destinadas ao plantio, a empresa A resolveu fazer uma parceria com outras duas empresas: uma do ramo de pecuária e uma de cana. Ambas as empresas apresentam uma demanda alternada ao longo do ano em relação à demanda da empresa E. Seu principal concorrente é a empresa G.

Foi realizada uma visita e entrevista na empresa A no dia 07 de abril de 2005 e o entrevistado foi o superintendente geral e gerente do projeto Lean da empresa, sendo ele o principal agente de mudança.

O projeto de implementação de Produção Enxuta começou em setembro de 2004, porque a empresa acreditou que este sistema produtivo levasse a uma maior eficiência e portanto maior produtividade. Como a empresa A tem uma parceria com a empresa E, e esta última já utilizava este sistema e queria estender aos seus parceiros, este fator externo foi decisivo na implementação do projeto.

A empresa A obteve um incremento de vendas no período de 2004 em $32 \%$, porém o entrevistado não soube afirmar se este aumento foi devido somente à eficiência do projeto Lean ou se foi a expansão da demanda de mercado como um todo.

Para a realização do projeto, a empresa A contou com a colaboração de uma consultoria, que já atuava na empresa parceira e justamente por esta razão ela foi escolhida para implementar o projeto.

A empresa A optou por fazer uma implementação piloto, escolhendo uma família específica de máquinas distribuidoras de fertilizantes e corretivos. Conforme o projeto foi obtendo avanços, algumas práticas foram implementadas em outras famílias de produtos.

Com o início do projeto, a empresa A formou uma equipe de 6 pessoas, composta pelo gerente geral do projeto (entrevistado) e os 5 líderes de cada área. Após a formação da equipe, a empresa A participou de um treinamento sobre a Produção Enxuta e suas ferramentas e técnicas. Neste treinamento participaram todos os funcionários da empresa.

Quando o projeto Lean começou os produtos fabricados pela empresa A estavam em alta demanda, mas com o período de entre-safra, que foi de outubro/2004 até março/2005, houve redução nas vendas e a empresa A precisou fazer parcerias com 
outras duas empresas para estabilizar a produção e não demitir seus funcionários, o que caracterizou como uma dificuldade para a implementação, uma vez que estes novos parceiros não trabalhavam com Produção Enxuta.

Após o treinamento inicial foi feito um mapeamento da situação atual e construção da situação futura, através do mapa do fluxo de valor.

Quando ocorreu a implementação deste projeto, foi utilizado o 5S, que trouxe grandes transformações no chão-de-fábrica da empresa, melhorando o ambiente de trabalho e servindo como base para a disseminação de conceitos de Produção Enxuta.

A padronização do trabalho e o kanban foram utilizados na família escolhida e posteriormente estendido seu uso para outras famílias. O layout celular também foi utilizado, porém não extensivamente. Seu uso ficou restrito em algumas áreas.

Foi feito um nivelamento de produção através do heijunka box, o que possibilitou ajustes e reprogramação dos operadores quando necessário.

O projeto não abordou a administração da qualidade total dos produtos, embora o entrevistado percebesse que houve uma melhora na qualidade dos produtos devido as melhorias dos processos produtivos.

A manutenção produtiva total também não foi trabalhada, porém o entrevistado acreditava que tanto ela quanto a administração da qualidade total são práticas muito importantes e que deverão ser trabalhadas com o decorrer do projeto.

Quanto ao custeio dos produtos finais envolvidos no projeto de Produção Enxuta, ele é feito pela empresa E, não cabendo uma análise mais detalhada pela empresa A. Aparentemente o sistema de custeio não mudou devido ao projeto.

A empresa A não possui medidas de desempenho de máquinas produzidas por operadores e medição de tempo de setup, e o projeto ainda não abordou esses indicadores.

Segundo o entrevistado, a empresa A tinha uma baixa produtividade e uma demanda alta pelos seus produtos. Antes do projeto Lean, a empresa A apresentava um takt time de 2 horas, na família escolhida, e no momento da entrevista o mesmo estava em 52 minutos, o que mostra uma redução de aproximadamente $57 \%$.

$\mathrm{O}$ investimento feito pela empresa $\mathrm{A}$ foi apenas no fornecimento da mãode-obra. $\mathrm{O}$ custo com a consultoria e com o material necessário foi pago pela empresa parceira E.

Após este período de desenvolvimento e implementação do projeto, a 
empresa A conseguiu obter os resultados, descritos na tabela 3.

Tabela 3 - Resultados obtidos no projeto Lean - Empresa A

\section{Indicadores}

\section{Pontuação}

Aumento da Produtividade

Aumento da Pontualidade de entrega

Redução do lead time

Redução dos custos de fabricação

Aumento do faturamento

4

4

Aumento da lucratividade

Diminuição de matéria-prima

Diminuição de material em processo

Diminuição de produto acabado

Redução da área de produção

Redução de movimentação de material e pessoas

Aumento de participação no mercado consumidor

Mudanças culturais dos funcionários

Influenciou a política de vendas

Mudanças no desenvolvimento do produto

Aumentou a qualidade dos produtos

Aumento no mix de produtos

Influenciou os fornecedores

Aumentou os fornecedores

Diminuiu os fornecedores

Alterou os fluxos de informações
4

3

3

4

4

4

0

3

4

4

4

0

0

3

2

4

2

2

4

\subsubsection{A empresa B}

A empresa B está localizada na cidade de São Carlos-SP e foi fundada no ano de 1964. Conta hoje com aproximadamente 80 funcionários, atuando no ramo de máquinas de pecuária e de gado de corte. Seus principais produtos são misturadores e colhedeiras de forragem.

Em 2004 o faturamento da empresa chegou a aproximadamente 10 milhões de reais. 
A empresa B tem parcerias com algumas revendas, mas a maioria de suas vendas é feita diretamente com a área comercial. Seus principais clientes são os grandes produtores de leite e de confinamento de gado. No mercado internacional, a empresa B atua principalmente na América do Sul, Central e Norte, sendo as vendas de exportações feitas diretamente com a área comercial da empresa.

Um dos seus principais concorrentes é a empresa G, deste trabalho, além de outras também citadas.

A visita a esta empresa foi feita no dia 17 de março de 2005 e o entrevistado foi o gerente de produção e gerente do projeto Lean, sendo ele o principal agente de mudança.

O projeto Lean começou em outubro de 2004 justamente porque a empresa B apresentava uma grande quantidade de desperdícios ao longo do processo produtivo, sendo este o principal fator interno motivador de mudança. Também alguns funcionários visitaram outras empresas que utilizam a Produção Enxuta e gostaram dos resultados obtidos por elas.

A empresa B tem $70 \%$ da participação do mercado de misturadores e uma pequena parcela em colhedeiras de forragem, não mencionada a porcentagem exata pelo entrevistado.

Neste projeto Lean, a empresa B contou com a colaboração de uma consultoria, porque o presidente da empresa assistiu à algumas palestras e entrou em contato diretamente com o consultor. O entrevistado acredita que a razão da escolha seja porque esta consultoria foi indicada pela empresa D.

Inicialmente a implementação do projeto Lean foi piloto, sendo a família escolhida uma colhedeira de forragem, justamente porque ela é uma máquina simples e estava em baixa produção, tendo tempo para trabalhar no processo produtivo da mesma.

Com o início do projeto, a empresa B formou um grupo de 18 pessoas, que depois foi dividido em 3 equipes de atuação, cada uma com um líder (geralmente um gerente) e 5 funcionários, um de cada setor. Estas equipes atuavam juntamente com a consultoria.

Foi efetuado um treinamento de Produção Enxuta e suas práticas a todos os níveis hierárquicos da empresa. Nesta fase inicial, o entrevistado percebeu uma grande resistência por parte dos funcionários do chão-de-fábrica em aceitar as mudanças. $\mathrm{O}$ entrevistado acreditava que pela variedade de produtos da empresa seria difícil gerenciar através da Produção Enxuta. 
Quando ocorreu a implementação do projeto, a empresa aplicou a ferramenta de $5 \mathrm{~S}$ e fez um rearranjo no layout da fábrica, implementando o conceito de layout celular em todas as famílias. O kanban foi outra prática muito utilizada na família em questão e em outras posteriormente. Já a padronização do trabalho foi utilizada, mas não de forma extensiva.

No momento da visita e entrevista, a empresa não tinha utilizado e/ou implementado as seguintes práticas: heijunka box, mapa do fluxo de valor, manutenção produtiva total e administração da qualidade total, embora o entrevistado acreditasse que todas elas seriam importantes no projeto. Segundo o entrevistado houve uma melhora percebida na qualidade do produto, resultante da melhoria dos processos.

Até a época em que foi feita a entrevista, a empresa não fazia custeio do produto. Ela simplesmente fazia uma pesquisa de preço dos concorrentes e com base nisso estabelecia o seu preço de venda. Segundo o entrevistado, o projeto Lean ainda não abordou o gerenciamento de custo, mas afirmou que a empresa está buscando uma formatação deste sistema.

Através da implementação piloto, a empresa conseguiu um aumento de produtividade, principalmente no setor de montagem, que foi de cerca de $33 \%$. Porém a empresa ainda não possui uma medida de desempenho formal de avaliação contínua da produtividade em termos de máquinas produzidas por operador. O projeto ainda não abordou este indicador. O tempo de setup não era medido e o projeto Lean ainda não abordou esta medida.

Com a implementação do projeto, a empresa conseguiu fabricar uma máquina por dia, ou seja, uma máquina a cada 8 horas, sendo este seu takt time no momento da entrevista, justamente pela baixa demanda.

A empresa B não forneceu o valor investido no projeto. O principal investimento foi em consultoria. A fabricação de pallets, cartões, etc., foi feita reutilizando sobras de materiais, disponíveis com o uso dos $5 \mathrm{~S}$.

Após um período de desenvolvimento e implementação do projeto, a empresa B conseguiu obter os seguintes resultados, descritos na tabela 4. 
Tabela 4 - Resultados obtidos no projeto Lean - Empresa B

\begin{tabular}{|c|c|}
\hline Indicadores & Pontuação \\
\hline Aumento da Produtividade & 3 \\
\hline Aumento da Pontualidade de entrega & 3 \\
\hline Redução do lead time & 3 \\
\hline Redução dos custos de fabricação & 0 \\
\hline Aumento do faturamento & 0 \\
\hline Aumento da lucratividade & 0 \\
\hline Diminuição de matéria-prima & 3 \\
\hline Diminuição de material em processo & 3 \\
\hline Diminuição de produto acabado & 3 \\
\hline Redução da área de produção & 4 \\
\hline Redução de movimentação de material e pessoas & 3 \\
\hline Aumento de participação no mercado consumidor & 0 \\
\hline Mudanças culturais dos funcionários & 3 \\
\hline Influenciou a política de vendas & 0 \\
\hline Mudanças no desenvolvimento do produto & 0 \\
\hline Aumentou a qualidade dos produtos & 3 \\
\hline Aumento no mix de produtos & 0 \\
\hline Influenciou os fornecedores & 0 \\
\hline Aumentou os fornecedores & 2 \\
\hline Diminuiu os fornecedores & 2 \\
\hline Alterou os fluxos de informações & 3 \\
\hline
\end{tabular}

\subsubsection{A empresa $C$}

A empresa C está localizada na cidade de Ribeirão Preto-SP e atua no ramo de máquinas e implementos agrícolas, produzindo colhedeiras, trituradores, debulhadores e forrageiras.

Ela conta com aproximadamente 98 funcionários e o entrevistado não forneceu o faturamento anual.

Esta empresa em 1999 fez uma parceria com a empresa E, fabricando seus produtos com o nome da última e ganhando royalties com isso. Também produz peças para as máquinas da empresa E. Sendo assim, seu principal cliente é a empresa E. 
É concorrente da empresa A.

A visita nesta empresa foi realizada dia 14 de abril de 2005 e os entrevistados foram os dois principais agentes de mudança no projeto Lean: o supervisor de segurança do trabalho e o chefe do almoxarifado.

O projeto Lean começou em julho de 2004, porque a empresa C percebeu que os consumidores estavam mais exigentes, precisando acompanhar esta mudança. Além disso, a empresa detectou grandes desperdícios decorrentes de fluxo de informação deficiente. Outro fator motivador foi a parceria com a empresa E, que já trabalhava com a Produção Enxuta e queria estender para seus parceiros.

A empresa $\mathrm{C}$ não tem os dados referentes à participação no mercado consumidor, uma vez que todas as informações comerciais são centralizadas na empresa parceira E.

A empresa $\mathrm{C}$ contou com a ajuda de uma consultoria, que já trabalhava com a empresa parceira. O projeto Lean teve como foco as 4 famílias de produtos, sendo elas assim denominadas: plataformas, eixos sextavados, kits e colhedeiras. A estratégia de implementação neste caso foi programática, pois contemplou todas as famílias da empresa em questão e é um projeto de longo prazo com poucos resultados medidos imediatamente.

Com o início do projeto, a empresa formou uma equipe que contou com um gerente do projeto, um funcionário do setor de usinagem e um do setor de montagem, além dos consultores e dos entrevistados. A partir desta formação, foi dado um treinamento em Produção Enxuta e em algumas práticas para a equipe e para a diretoria.

Foi feito um levantamento da situação atual e do layout da fábrica. Posteriormente foi desenhada a situação futura, através do mapa do fluxo de valor.

Uma das dificuldades da empresa $\mathrm{C}$ era a falta de dados consistentes que o projeto Lean necessitava. Foi feito, então, um levantamento extensivo desses dados antes da implementação, o que acabou retardando o andamento do projeto.

Quando ocorreu o início da implementação, a empresa C percebeu outra dificuldade: a resistência dos funcionários do chão-de-fábrica em trabalhar no novo sistema.

A implementação se iniciou com a aplicação dos $5 \mathrm{~S}$ em toda a empresa e rearranjos no layout, com a implementação do layout celular. O kanban também foi implementado e um quadro de nivelamento da produção estava prestes a ser 
implementado na ocasião da visita à empresa. Naquele momento, as práticas de padronização do trabalho, de manutenção produtiva total e de administração da qualidade total não tinham sido implementadas, embora os entrevistados acreditassem que elas eram importantes para o projeto. Segundo os entrevistados foi percebida a uma melhora na qualidade do produto em consequiência de melhoras feitas nos processos.

A empresa $\mathrm{C}$ utiliza um sistema simples de custeio por rateio do custo de mão de obra e este sistema não se alterou com o projeto Lean.

As medidas de desempenho de máquinas por operador, de tempo de setup e de takt time não eram utilizadas e o projeto Lean, até aquele momento não tinha ainda abordado essas medidas.

$\mathrm{O}$ investimento da empresa $\mathrm{C}$ no projeto não foi significativo, segundo os entrevistados, pois a consultoria era paga pela empresa $\mathrm{E}$.

Após o período de desenvolvimento e implementação do projeto, a empresa $\mathrm{C}$ conseguiu obter os resultados, descritos a seguir na tabela 5.

Tabela 5 - Resultados obtidos no projeto Lean - Empresa C

\section{Indicadores}

\section{Pontuação}

Aumento da Produtividade

Aumento da Pontualidade de entrega

Redução do lead time

Redução dos custos de fabricação

Aumento do faturamento

Aumento da lucratividade

Diminuição de matéria-prima

Diminuição de material em processo

Diminuição de produto acabado

Redução da área de produção

Redução de movimentação de material e pessoas

Aumento de participação no mercado consumidor

Mudanças culturais dos funcionários

Influenciou a política de vendas

Mudanças no desenvolvimento do produto 
Aumento no mix de produtos

Influenciou os fornecedores

Aumentou os fornecedores

Diminuiu os fornecedores

Alterou os fluxos de informações

$\mathrm{Na}$ empresa $\mathrm{C}$ muitos indicadores ainda não tinham sido levados no momento da entrevista. Os entrevistados afirmaram que esta seria a próxima etapa do projeto, justamente para verificar os ganhos do projeto, conseguir credibilidade por parte da empresa e dessa forma dar continuidade ao mesmo.

\subsubsection{A empresa $D$}

A empresa D está localizada na cidade de Pompéia-SP e sua fundação está datada no ano de 1949, atuando no ramo de máquinas e implementos agrícola. Ela produz uma linha de pulverizadores, desde costais manuais e motorizados, como tracionados por trator, acoplados e autopropelidos; colhedeiras e adubadeiras. Também possuí uma linha para limpeza industrial e doméstica, uma linha de saneamento e uma linha de carrinhos elétricos, utilizados em jogos de futebol.

No ano de 2004 seu faturamento foi aproximadamente de 900 milhões de reais, empregando cerca de 2.000 funcionários.

A empresa D vende seus produtos através de revendas, sendo que seus maiores clientes são duas grandes cooperativas. A exportação de seus produtos também é feita para mais de 80 países, correspondendo essas exportações em cerca de $20 \%$ do faturamento e seus principais concorrentes são as empresas F, I e outras.

A empresa D possui uma filial na Argentina e uma join-venture nos EUA.

Foi realizada uma visita e entrevista na empresa D no dia 04 de março de 2005 e o entrevistado foi o gerente de Planejamento e Controle da Produção e Logística e gerente do projeto Lean, sendo o principal agente de mudança, o presidente da empresa.

O projeto Lean começou em 2000, justamente quando houve um boom no agronegocio no Brasil naquele ano. E a empresa D percebeu que o mercado consumidor estava diferente e ela queria ter um diferencial em relação aos seus 
concorrentes, sendo este o principal fator motivacional para a mudança.

$\mathrm{Na}$ época a empresa $\mathrm{D}$ era líder de mercado em todas as linhas e não queria perder suas parcelas de participação. Na linha de pulverizadores ela tinha cerca de $70 \%$ e de colhedeiras e adubadeiras cerca de $60 \%$.

Alguns funcionários da empresa D participaram do Lean Summit 1999, realizado na empresa Mercedes e a partir deste momento entrou-se em contato com o Lean Institute Brasil para implementar seu projeto.

A princípio a empresa optou por fazer uma implementação piloto com uma família específica de máquinas pulverizadoras acopladas. Com o passar do tempo, outras famílias foram sendo incluídas no projeto.

Para dar início ao projeto, a empresa D tomou algumas medidas. Primeiramente, ela formou uma equipe de 14 pessoas, com um líder (presidente da empresa) e os demais eram funcionários das diferentes áreas.

Após esta fase, foi feito um treinamento sobre Produção Enxuta e algumas práticas para o grupo e para os funcionários do setor de montagem.

Quando ocorreu a implementação do projeto Lean, a empresa D aplicou os 5S, para disseminar os conceitos de Produção Enxuta, mas ela já utilizava o kanban. $\mathrm{O}$ entrevistado ressaltou que a empresa $\mathrm{D}$ foi a primeira empresa brasileira a utilizar o kanban na década de 80.

Posteriormente foram introduzidos, nesta ordem: o heijunka box, a padronização do trabalho, o layout celular, o mapa do fluxo de valor, a manutenção produtiva total e administração da qualidade total. $O$ entrevistado salientou que na empresa $\mathrm{D}$ os conceitos desta última prática não estão muito solidificados nos funcionários.

A empresa D possuía um sistema de custeio de produtos antes do projeto que não foi alterado com a implementação do projeto Lean.

A medida de desempenho "máquina por operador" e o desempenho de tempo de setup não eram medidos até o momento da entrevista.

No momento da entrevista, o takt time era de 120 máquinas por dia, ou seja, a cada 8 minutos em média a empresa produzia uma máquina, já que a mesma trabalha em dois turnos. Antes do projeto Lean, a empresa não utilizava esta medida.

A empresa D estima que gastou em consultoria, treinamento e equipamentos cerca de 300 mil reais, em todo o período do projeto.

Após o período de desenvolvimento e implementação do projeto, a 
empresa D conseguiu obter os resultados, descritos a seguir na tabela 6.

Tabela 6 - Resultados obtidos no projeto Lean - Empresa D

\section{Indicadores}

Pontuação

Aumento da Produtividade

Aumento da Pontualidade de entrega

Redução do lead time

Redução dos custos de fabricação

Aumento do faturamento

Aumento da lucratividade

Diminuição de matéria-prima

Diminuição de material em processo

Diminuição de produto acabado

Redução da área de produção

4

4

4

4

4

4

0

3

3

4

Redução de movimentação de material e pessoas

3

Aumento de participação no mercado consumidor

2

4

4

0

4

4

3

2

3

Diminuiu os fornecedores

Alterou os fluxos de informações

4

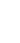

Aumento no mix de produtos

Influenciou os fornecedores

Aumentou os fornecedores

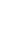

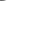

4

(1)

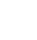

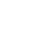

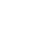

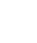

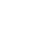

0

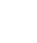

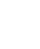

0

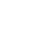

O entrevistado da empresa D afirmou que a liderança no mercado consumidor foi mantida por causa do projeto Lean. Ele acredita que se não tivesse implementado a Produção Enxuta na empresa provavelmente ela teria perdido parcelas de mercado para a concorrência.

\subsubsection{A empresa $E$}

A empresa E está localizada na cidade de Batatais-SP foi fundada em 1936. Atua no ramo de máquinas e implementos agrícolas, produzindo 4 linhas distintas 
de produtos: adubadeiras e semeadoras (para o plantio); colhedeiras (para a colheita); cultivadores (para a fertilização e transporte) e forrageiras, desintegradores e roçadeiras (para a pecuária).

Seu faturamento em 2004 foi aproximadamente de 200 milhões de reais, e emprega cerca de 650 funcionários, entre mão-de-obra direta e indireta.

Esta empresa em 1999 fez uma parceria com a empresa C e em 2000 fez com a empresa A, para que ambas produzissem seus produtos e colocassem a logomarca da empresa E em questão. Com isso a empresa E pode estar aumentando seu escopo de mercado e as outras empresas ganham royalties.

A empresa $\mathrm{E}$ vende seus produtos através de revendas para o mercado interno. Já para o externo, ela possui uma filial na África do Sul, mas exporta para a Venezuela. O México e a China são dois países que a empresa E está buscando aumentar sua participação.

Seus principais concorrentes são empresas multinacionais e de pequeno porte, não referentes a esta pesquisa.

Foi realizada uma visita e entrevista na empresa E no dia 22 de fevereiro de 2005 e o entrevistado foi o gerente de produção e gerente do projeto Lean, sendo o principal agente de mudança o presidente da empresa.

Em fevereiro de 2003, o projeto Lean começou na empresa E, porque a demanda era alta por seus produtos e ela não conseguia supri-la. A empresa E também não tinha um controle sobre seus gastos e por isso sempre estava tendo problemas com o fluxo de caixa, além de muitos desperdícios com as atividades que não agregavam valor no seu processo produtivo.

A empresa E teve a colaboração de uma consultoria, a qual já tinha implementado Produção Enxuta em outra indústria na mesma cidade.

A empresa E fez uma estratégia de implementação prototipal, abrangendo algumas das principais famílias de produtos, mas com resultados imediatos sendo obtidos.

Para dar início ao projeto, a empresa E precisou tomar algumas medidas. Inicialmente foi formada uma equipe, com um líder, um funcionário do PCP, dois do setor de tempos e métodos, um da engenharia de processos e seis da ferramentaria.

Posteriormente foi feito um treinamento sobre Produção Enxuta e algumas práticas para a equipe, gerentes e supervisores. Houve um treinamento específico para todos os funcionários e alguns fornecedores. E a equipe do projeto 
passou por outro treinamento depois.

Um problema levantado pelo entrevistado foi justamente a morosidade no entendimento dos conceitos e questionamento quanto à viabilidade do projeto de uma maneira geral por parte dos funcionários.

A empresa E já utilizava o kanban antes do inicio do projeto, mas havia uma má utilização. Com o uso do mapa do fluxo de valor, a empresa identificou o TPT e melhorou seu funcionamento.

Outras práticas também foram introduzidas como: os $5 \mathrm{~S}$, a padronização do trabalho, o heijunka box, o layout celular e a administração da qualidade total. Somente a manutenção produtiva total não foi implementada, embora o entrevistado acreditasse que ela é muito importante. Segundo o entrevistado, a prática de layout celular não seria implementada extensivamente na empresa.

A empresa $\mathrm{E}$ possui em sistema de custeio, mas ele ainda não foi modificado com o projeto Lean.

A empresa não possui um sistema de medição de desempenho de máquinas por operador. $\mathrm{O}$ entrevistado comentou que ela tem um sistema chamado GPD (Gerenciamento Pelas Diretrizes), que fornece prêmios para os funcionários por participação nos resultados (ver no apêndice F).

Quanto ao tempo de setup, a empresa E tinha feito um trabalho no setor de estamparia. Com o projeto Lean, houve uma redução no setor de solda, que era de 30 minutos e passou a ser 5 minutos.

O takt time antes do projeto era de uma máquina a cada 45 minutos e em 2004 passou a ser uma máquina a cada 30 minutos, quando este período estava em alta demanda. Mas no período da entrevista, o entrevistado ressaltou que não havia demanda por motivos externos à empresa como falta de financiamentos e mau desempenho da economia global.

O investimento estimado pela empresa $\mathrm{E}$ foi de $\mathrm{R} \$ 120.000,00$, gastos em consultoria, material para fazer palles e a compra de uma empilhadeira elétrica.

Após o período de desenvolvimento e implementação do projeto, a empresa E conseguiu obter os resultados, descritos a seguir na tabela 7. 
Tabela 7 - Resultados obtidos no projeto Lean - Empresa E

\begin{tabular}{|c|c|}
\hline Indicadores & Pontuação \\
\hline Aumento da Produtividade & 4 \\
\hline Aumento da Pontualidade de entrega & 3 \\
\hline Redução do lead time & 3 \\
\hline Redução dos custos de fabricação & 3 \\
\hline Aumento do faturamento & 3 \\
\hline Aumento da lucratividade & 4 \\
\hline Diminuição de matéria-prima & 4 \\
\hline Diminuição de material em processo & 4 \\
\hline Diminuição de produto acabado & 4 \\
\hline Redução da área de produção & 4 \\
\hline Redução de movimentação de material e pessoas & 4 \\
\hline Aumento de participação no mercado consumidor & 4 \\
\hline Mudanças culturais dos funcionários & 3 \\
\hline Influenciou a política de vendas & 3 \\
\hline Mudanças no desenvolvimento do produto & 3 \\
\hline Aumentou a qualidade dos produtos & 3 \\
\hline Aumento no mix de produtos & 3 \\
\hline Influenciou os fornecedores & 3 \\
\hline Aumentou os fornecedores & 3 \\
\hline Diminuiu os fornecedores & 2 \\
\hline Alterou os fluxos de informações & 3 \\
\hline
\end{tabular}

\subsubsection{A empresa $F$}

Localizada na cidade de Jaboticabal-SP e fundada em 1965, a empresa F atua no ramo de máquinas agrícolas, produzindo pulverizadores e atomizadores.

Realiza suas vendas através de revendas ou com representantes comerciais. As exportações são feitas através do contato direto com a empresa.

Seus principais concorrentes são as empresas D e I. E seu número de funcionários está em torno de 80.

O faturamento da empresa não foi fornecido pelo entrevistado. E sua participação no mercado consumidor é de terceiro lugar no ranking nacional de 
pulverizadores e atomizadores.

A visita e entrevista à empresa foram realizadas no dia 09 de março de 2005 com o gerente de produção e gerente de projeto, sendo o principal agente de mudança o presidente da empresa.

O projeto de implementação da Produção Enxuta começou em março de 2004, porque a empresa tinha um sistema produtivo desorganizado e sem controle sobre o mesmo, além de dificuldades de informações confiáveis, sendo estes fatores internos os motivadores para a implementação.

A empresa F contou com a colaboração de uma consultoria, contactada no evento da ABIMAQ- CSMIA, em 2003.

A estratégia de implementação adotada foi a piloto, sendo que foram identificadas quatro famílias de produtos e escolhida uma família de pulverizadores pela sua importância de vendas.

Para dar início ao projeto Lean, a empresa $\mathrm{F}$ precisou tomar algumas medidas. Primeiramente foi formada uma equipe, que tinha como participantes o gerente do projeto, um funcionário do setor de usinagem, um do setor da solda e um da injeção, além dos consultores. A equipe também contava com alguns auxiliares como três abastecedores, que abasteciam as linhas de produção.

Posteriormente foi feito um treinamento de Produção Enxuta e algumas práticas para a equipe do projeto. A empresa teve a preocupação em deixar os funcionários se familiarizarem com os novos conceitos, pois o entrevistado comentou que a mudança organizacional é lenta para ser assimilada.

O passo seguinte foi o levantamento da situação atual, com o uso do mapa do fluxo de valor. Neste momento um dos problemas encontrados foi a falta de dados consistentes, o que acabou prejudicando o ritmo do andamento do projeto, na visão do entrevistado.

A partir da situação atual foi planejada a situação futura e implementadas as práticas, como o layout celular, colocando prateleiras, divisórias, etc.

A padronização do trabalho, o kanban e o heijunka box também foram implementadas na empresa F. Até o momento da entrevista, o 5S não tinha sido implementado, embora o entrevistado comentou ser seu uso muito importante. Quanto a manutenção produtiva total e administração da qualidade total, a empresa não utilizou.

Os funcionários da empresa $\mathrm{F}$ estavam trabalhando em um sistema de custeio em paralelo com o projeto Lean, sendo que este último estava ajudando no 
desenvolvimento do primeiro.

A empresa $\mathrm{F}$ não possuía um sistema de medição de desempenho antes do projeto e com o projeto Lean sentiu-se a necessidade de alguns dados e o processo de medição se iniciou, porém os resultados ainda não tinham sido levantados.

Com a implementação do projeto Lean, foi feito um levantamento do tempo de setup das máquinas, passado pelo funcionário encarregado do processo. Mas o projeto, naquele momento, não tinha feito uma medição de desempenho para esta medida.

Segundo o entrevistado, antes do projeto a empresa produzia uma máquina a cada 111 minutos (1 hora e 51 minutos). Depois da implementação do projeto a empresa tinha capacidade de produzir a um takt time de uma máquina a cada 73 minutos (1 hora e 13 minutos), apresentando uma redução de aproximadamente $35 \%$.

Quanto ao investimento feito no projeto Lean, o entrevistado da empresa F não quis divulgar este dado.

Após o período de desenvolvimento e implementação do projeto, a empresa F conseguiu obter os resultados, descritos a seguir na tabela 8 .

Tabela 8 - Resultados obtidos no projeto Lean - Empresa F

\begin{tabular}{l|c}
\multicolumn{1}{c|}{ Indicadores } & Pontuação \\
Aumento da Produtividade & 4 \\
Aumento da Pontualidade de entrega & 4 \\
Redução do lead time & 4 \\
Redução dos custos de fabricação & 0 \\
Aumento do faturamento & 0 \\
Aumento da lucratividade & 0 \\
Diminuição de matéria-prima & 4 \\
Diminuição de material em processo & 4 \\
Diminuição de produto acabado & 4 \\
Redução da área de produção & 4 \\
Redução de movimentação de material e pessoas & 4 \\
Aumento de participação no mercado consumidor & 4 \\
Mudanças culturais dos funcionários & 0
\end{tabular}


Influenciou a política de vendas

Mudanças no desenvolvimento do produto

Aumentou a qualidade dos produtos

Aumento no mix de produtos

Influenciou os fornecedores

Aumentou os fornecedores

Diminuiu os fornecedores

Alterou os fluxos de informações
3

\section{(1)}

0

0

0

0

4

No momento da entrevista, a empresa $F$ tinha levantado poucos indicadores de resultados do projeto, sendo esta uma necessidade comentada pelo entrevistado.

\subsubsection{A empresa $G$}

A empresa $G$ está localizada no município de Cajuru -SP e foi fundada em 1950, atuando no ramo de máquinas e implementos agrícolas. Produz colhedeira de forragem e trituradores para a pecuária.

No ano de 2004. a empresa $G$ teve um faturamento de aproximadamente 15 milhões de reais, empregando cerca de 85 funcionários.

Suas vendas internas são feitas através de revendas autorizadas. Para a exportação, a empresa $G$ realiza as vendas através de representantes comerciais. No México a empresa tem uma parceria com uma revendedora.

As empresas A e B juntamente com outras atuam como concorrentes da empresa G.

A visita e entrevista a esta empresa foi realizada no dia 28 de abril de 2005 e os entrevistados foram o gerente de desenvolvimento de projeto e gerente de desenvolvimento de produção. Ambos coordenavam o projeto Lean, sendo eles os principais agentes de mudança.

A empresa $G$ trabalhava com produção em lote, mas o diretor-presidente teve conhecimento de Produção Enxuta e enviou alguns funcionários para a empresa D. Naquele período, a empresa $G$ tinha muitos estoques e não conseguia pagar seus funcionários em dia, sendo estes os fatores internos motivacionais. 
Logo em seguida foi feito um trabalho de $5 \mathrm{~S}$ e rearranjo do layout em célula na empresa toda por um gerente que acabou saindo da empresa. Formada uma nova coordenação deu-se início ao projeto Lean propriamente dito em agosto de 2004.

A empresa $G$ queria aumentar o desempenho na velocidade de entrega para seus clientes e assim aumentar a participação no mercado consumidor. Antes do início do projeto, a empresa $\mathrm{G}$ obtinha cerca de $20 \%$ do mercado consumidor. E no momento da entrevista, esta parcela dobrou, chegando a $40 \%$.

A empresa $\mathrm{G}$ contou com o apoio de uma consultoria, contratada através do diretor-presidente e recomendada pela empresa D.

A empresa $\mathrm{G}$ optou por uma implementação piloto, escolhendo uma família de colhedeira de forragem.

Com o início do projeto Lean, a empresa $\mathrm{G}$ formou uma equipe, com sete funcionários, sendo eles dos setores: de projeto, de corte, de prensa, de montagem e desenvolvimento de produção, além dos entrevistados.

Posteriormente foi feito um treinamento para a equipe e depois para todos os funcionários do chão-de-fábrica, sobre Produção Enxuta e algumas práticas.

Como a empresa G já utilizava o $5 \mathrm{~S}$ e o layout celular, ela optou por implementar o kanban na família piloto e a administração da qualidade total na empresa.

Até o momento da entrevista, a empresa $G$ não tinha implementado a padronização do trabalho e o heijunka box, embora o entrevistado acreditasse que sua implementação era muito importante. O mapa do fluxo de valor e a manutenção produtiva total também não foram utilizados e os entrevistados não opinaram quanto a importância de cada prática no projeto por falta de conhecimento.

Com o inicio do projeto Lean surgiram alguns problemas, relatados pelos entrevistados como: a conscientização dos funcionários com o novo sistema produtivo. Outro problema foi o gerenciamento da empresa, que estava em uma fase intermediária, pois trabalhava com sistema de lotes e a implementação do projeto Lean na família piloto.

A empresa possuía um sistema de custeio, mas estava sendo feita uma catalogação de todas as peças e colocando esses dados em um sistema informatizado, para posteriormente fazer um estudo no gerenciamento de custos.

A medição de desempenho máquina por operador e de tempo de setup não eram feitas e o projeto ainda não tinha abordado estas medidas. 
Segundo os entrevistados, antes do projeto a empresa produzia uma máquina da família piloto a cada 180 minutos. Depois da implementação o takt time passou a ser uma máquina a cada 105 minutos, mostrando uma redução de aproximadamente $42 \%$.

Até o momento da entrevista, a empresa $G$ tinha gasto cerca de $\mathrm{R} \$$ $5.000,00$ com consultoria. Ela utilizou sobras de material para fazer pallets, prateleiras cartões, etc.

Após o período de desenvolvimento e implementação do projeto, a empresa $\mathrm{G}$ conseguiu obter os resultados, descritos a seguir na tabela 9.

Tabela 9 - Resultados obtidos no projeto Lean - Empresa G

\begin{tabular}{l|c}
\multicolumn{1}{c|}{ Indicadores } & Pontuação \\
Aumento da Produtividade & 3 \\
Aumento da Pontualidade de entrega & 4 \\
Redução do lead time & 4 \\
Redução dos custos de fabricação & 0 \\
Aumento do faturamento & 3 \\
Aumento da lucratividade & 3 \\
Diminuição de matéria-prima & 4 \\
Diminuição de material em processo & 4 \\
Diminuição de produto acabado & 4 \\
Redução da área de produção & 4 \\
Redução de movimentação de material e pessoas & 4 \\
Aumento de participação no mercado consumidor & 4 \\
Mudanças culturais dos funcionários & 3 \\
Influenciou a política de vendas & 3 \\
Mudanças no desenvolvimento do produto & 4 \\
Aumentou a qualidade dos produtos & 4 \\
Aumento no mix de produtos & 4 \\
Influenciou os fornecedores & 4 \\
Aumentou os fornecedores & 4 \\
Diminuiu os fornecedores & 4 \\
Alterou os fluxos de informações & 4 \\
\hline
\end{tabular}




\subsubsection{A empresa $H$}

A empresa $\mathrm{H}$ está localizada na cidade de Pindorama-SP e pertence a um grupo de empresas fundado em 1972. Conta hoje com 174 funcionários com um faturamento anual de aproximadamente de $\mathrm{R} \$ 60$ milhões e atua no ramo de implementos agrícolas, produzindo uma linha completa para a colheita de feijão como: ceifadores, que cortam e colhem os grãos, transferidores de linha, que limpam, carretas graneleiras, que separa os grãos e recolhedoras, que armazenam.

A empresa $\mathrm{H}$ opera a maior parte de suas vendas através de revendas. A exportação é feita através do grupo da qual a empresa faz parte, vendendo para os Estados Unidos. No momento da entrevista, a empresa $\mathrm{H}$ estava iniciando suas vendas no mercado da África e Europa.

Seus produtos sofrem a concorrência de outras empresas não mencionadas no trabalho.

A visita a esta empresa foi feita no dia 10 de Maio de 2005 e o entrevistado foi o consultor do projeto, sendo ele e a equipe formada pelos funcionários os principais agentes de mudança.

O projeto Lean começou em novembro de 2003, porque a empresa $\mathrm{H}$ tinha altos estoques; baixa produtividade; excesso de horas extras, gerando um alto custo de manufatura. Por essas razões internas, a empresa decidiu implementar a Produção Enxuta, para atacar esses desperdícios e não sofrer tanto quando a demanda estivesse baixa.

Um fator externo que ajudou na escolha da implementação de Produção Enxuta, foi o conhecimento da implementação na empresa D.

Neste projeto Lean, a empresa $\mathrm{H}$ contou com a colaboração de uma consultoria, indicada pela empresa $\mathrm{D}$.

A empresa $\mathrm{H}$ optou por uma implementação prototipal, onde estão sendo trabalhadas algumas das principais famílias de produtos. Ela optou por fazer esta estratégia de implementação porque se está buscando a mudança cultural organizacional, juntamente com resultados.

Com o início do projeto, a empresa $\mathrm{H}$ formou uma equipe com funcionários da média e alta gerência, para atuar conjuntamente com a consultoria. Esta equipe era formada por doze pessoas da empresa das diversas áreas.

Posteriormente foi feito um treinamento para esta equipe sobre Produção 
Enxuta e algumas práticas como os 5S, kanban e mapa do fluxo do valor.

O próximo passo foi o mapeamento da situação atual, onde foram levantados os processos produtivos algumas famílias. Com esta situação foram identificadas as ações que deveriam ser feitas e realizou-se uma primeira implementação que incluiu os 5S e o kanban.

Como os funcionários do chão de fábrica não receberam treinamentos sobre as práticas, eles resistiram às mudanças e a continuidade das melhorias foi prejudicada, o que acabou gerando dificuldades do projeto. Detectadas estas dificuldades, a equipe providenciou um treinamento para todos os funcionários e depois deram início a uma nova fase de implementação. Outra dificuldade encontrada foi a falta de tempo suficiente para que os funcionários se dedicassem ao projeto, justamente porque naquele período a demanda estava alta.

Até o momento da entrevista, o entrevistado comentou que a empresa $\mathrm{H}$ não tinha implementado a padronização do trabalho, o layout celular, o heijunka box, a manutenção produtiva total e administração da qualidade total. Embora o entrevistado acreditasse que todas são muito importantes para o projeto Lean e a qualidade dos produtos tenha aumentado. A única discordância assinalada, pelo entrevistado está quanto ao uso extensivo do layout celular na empresa, já que ele acredita que seu uso deva ser feito somente em alguns pontos.

A empresa $\mathrm{H}$ possui um sistema de custeio, mas ele está sendo modificado pelo projeto Lean, que estava fazendo adaptações para atender suas necessidades.

Quanto ao sistema de medição de desempenho de máquina por operador e medição de tempo de setup, a empresa $\mathrm{H}$ não possui. No caso do primeiro, a empresa $\mathrm{H}$ está aguardando o término do sistema de custeio para conseguir os dados para medir o desempenho de seus funcionários. No caso da medição de tempo de setup, a empresa H tem uma proposta para ser implementada, mas até aquele momento ela não estava em uso.

Segundo o entrevistado, o takt time medido foi da família de recolhedoras, que sofreu alterações de produto. Antes do projeto, a empresa produzia cinco máquinas por dia, ou seja, cinco máquinas em oito horas. Com o projeto Lean, muitas melhorias foram feitas e o entrevistado acreditava que seria possível uma produção maior desde que houvesse uma demanda. No momento da entrevista, o takt time era de 3 máquinas/dia, porque a demanda estava baixa. O entrevistado comentou 
que os funcionários estavam fazendo melhorias no processo produtivo no tempo ocioso.

O investimento estimado foi de $\mathrm{R} \$ 70.000,00$ em consultoria e outros gastos como a fabricação de carrinhos, pallets, etc. foram inexpressivos e por isso não foram contabilizados pela empresa.

Após o período de desenvolvimento e implementação do projeto, a empresa $\mathrm{H}$ conseguiu obter os resultados, descritos a seguir na tabela 10.

Tabela 10 - Resultados obtidos no projeto Lean - Empresa $\mathrm{H}$

\begin{tabular}{|c|c|}
\hline Indicadores & Pontuação \\
\hline Aumento da Produtividade & 4 \\
\hline Aumento da Pontualidade de entrega & 4 \\
\hline Redução do lead time & 4 \\
\hline Redução dos custos de fabricação & 0 \\
\hline Aumento do faturamento & 2 \\
\hline Aumento da lucratividade & 0 \\
\hline Diminuição de matéria-prima & 4 \\
\hline Diminuição de material em processo & 4 \\
\hline Diminuição de produto acabado & 0 \\
\hline Redução da área de produção & 4 \\
\hline Redução de movimentação de material e pessoas & 4 \\
\hline Aumento de participação no mercado consumidor & 0 \\
\hline Mudanças culturais dos funcionários & 4 \\
\hline Influenciou a política de vendas & 0 \\
\hline Mudanças no desenvolvimento do produto & 0 \\
\hline Aumentou a qualidade dos produtos & 4 \\
\hline Aumento no mix de produtos & 3 \\
\hline Influenciou os fornecedores & 3 \\
\hline Aumentou os fornecedores & 2 \\
\hline Diminuiu os fornecedores & 2 \\
\hline Alterou os fluxos de informações & 4 \\
\hline
\end{tabular}

\subsubsection{A empresa I}

A empresa I está localizada na cidade de São José dos Pinhais-PR e foi 
fundada em 1996. Conta hoje com aproximadamente 300 funcionários, atuando no ramo de máquinas e implementos agrícolas.

Produz uma linha de pulverizadores, que se estende desde os acoplados no trator, os de arrasto, puxados por trator, com turbina (atomizadores) e canhões e os autopropelidos (pulverizadores com motor e cabine).

No ano de 2004, seu faturamento foi aproximadamente de $\mathrm{R} \$ 170$ milhões de reais.

A empresa I vende seus produtos para o mercado nacional através de revendas ou diretamente com a área comercial, dependendo do tipo de produto. As exportações também são feitas por revendas e a empresa possui uma filial na Argentina.

Seus principais concorrentes são as empresas D e F, além de outras.

Foi realizada uma visita e entrevista na empresa I no dia 20 de abril de 2005 e a entrevistada foi a gerente de produção e gerente do projeto Lean, sendo ela e uma sócia-proprietaria as principais agentes de mudança.

O projeto Lean começou em maio de 2003, porque a empresa tinha um produto com alta demanda e ela não conseguia atendê-la, sendo assim, o principal fator externo para a mudança foi a alta demanda e fatores internos, a necessidade de conseguir atender o mercado consumidor na quantidade que ele exigia.

No caso da empresa I, ela contou com o apoio do Lean Institute Brasil na implementação do projeto, sendo que são enviados consultores do próprio instituto para a empresa quando a mesma os solicita.

A empresa I escolheu uma família de pulverizadores autopropelidos para fazer a implementação piloto, justamente pela alta demanda por estes produtos. Com a evolução do projeto, outras famílias foram incorporadas ao projeto Lean.

Com o início do projeto, a empresa I precisou tomar algumas medidas como a formação de uma equipe de onze funcionários, não dedicados, das áreas de engenharia, qualidade, suprimentos, produção, comercial e financeiro, além da entrevistada.

Esta equipe passou por um treinamento de dois dias com o pessoal do Lean Institute Brasil, onde foi feito o mapeamento da situação atual, utilizando o mapa do fluxo de valor. Posteriormente este grupo foi dividido em três, para atacarem problemas diferentes.

No início da implementação do projeto Lean, a empresa I percebeu algumas dificuldades como a falta de envolvimento do pessoal do chão-de-fábrica. Eles 
sentiam que todas as melhorias deveriam ser creditadas para a equipe e não para a empresa toda. Em 2004, a equipe do projeto criou uma função de apoiador, que fazia um elo entre a equipe e os funcionários, minimizando esta dificuldade.

Quanto às outras práticas utilizadas, a entrevistada comentou que antes do projeto Lean, a empresa I já utilizava o kanban, porém seu uso era incorreto e mal implementado. Com este projeto, o uso foi corrigido e os kanbans, que antes entregavam peças foram planejados para entregar kits para as estações de trabalho.

Os 5S foram implementados, mas não foi a primeira prática na família piloto. Porém quando o projeto incorporou outras famílias, o trabalho começou com esta prática.

O layout celular foi implementado na família piloto e estava sendo implementado em outras famílias. O que também ocorreu com a padronização do trabalho.

O heijunka box não foi aplicado, até aquele momento, porque os processos produtivos envolvidos no projeto (solda, pintura e montagem) da família piloto trabalham em lotes unitários. Como próximos passos a empresa I planeja implementar o heijunka box no setor de metalurgia, que fornece peças para todas as famílias.

A manutenção produtiva total e a administração da qualidade total ainda não tinham sido implementadas, até aquele momento.

Quanto ao sistema de custeio, a empresa I já possuía um anteriormente, mas o pessoal do financeiro estava trabalhando nos indicadores para ajustá-lo ao projeto Lean.

A empresa I possui um indicador de desempenho chamado Máquina Equivalente por Homem. Antes do inicio do projeto Lean, em 2002, este indicador era de 1,95 máquinas por homem. No momento da entrevista, este indicador estava em 12 máquinas por homem.

O sistema de medição do tempo de setup não era medido e quando o projeto Lean incluir o setor de metalurgia será introduzido um estudo deste indicador.

Segundo a entrevistada, o takt time antes do projeto, desta família de produtos era, em 2002, de 1 máquina por semana e em 2005 passou a ser 3 máquinas por dia.

O investimento no projeto Lean foi orçado em $\mathrm{R} \$ 100.000,00$, gastos em compra de livros, viagens e o apoio do Lean Institute Brasil. 
Após o período de desenvolvimento e implementação do projeto, a empresa I conseguiu obter os resultados, descritos a seguir na tabela 11.

Tabela 11 - Resultados obtidos no projeto Lean - Empresa I

\begin{tabular}{l|c}
\multicolumn{1}{c|}{ Indicadores } & Pontuação \\
Aumento da Produtividade & 4 \\
Aumento da Pontualidade de entrega & 4 \\
Redução do lead time & 4 \\
Redução dos custos de fabricação & 0 \\
Aumento do faturamento & 4 \\
Aumento da lucratividade & 4 \\
Diminuição de matéria-prima & 0 \\
Diminuição de material em processo & 4 \\
Diminuição de produto acabado & 0 \\
Redução da área de produção & 0 \\
Redução de movimentação de material e pessoas & 4 \\
Aumento de participação no mercado consumidor & 4 \\
Mudanças culturais dos funcionários & 4 \\
Influenciou a política de vendas & 4 \\
Mudanças no desenvolvimento do produto & 3 \\
Aumentou a qualidade dos produtos & 3 \\
Aumento no mix de produtos & 3 \\
Influenciou os fornecedores & 3 \\
Aumentou os fornecedores & 3 \\
Diminuiu os fornecedores & 3 \\
Alterou os fluxos de informações & 4 \\
\hline
\end{tabular}

No próximo capítulo serão feitas as comparações e análises das empresas e de seus projetos. 


\section{CAPítulo 5 - Análises de Dados e Resultados}

\subsection{Análises das empresas e dos Projetos Lean}

As empresas estudadas neste trabalho apresentam características diferentes entre si, embora sejam do mesmo setor. E os projetos Lean também foram conduzidos de forma bem distinta em cada uma delas. Portanto, este capítulo mostra estas diferenças e os resultados obtidos nos projetos, buscando responder aos objetivos gerais e específicos da pesquisa.

\subsubsection{Características das empresas e dos projetos Lean}

A partir das respostas obtidas pelo roteiro de entrevista, pode-se montar um cenário das empresas escolhidas neste trabalho.

Algumas características das empresas como número de funcionários, faturamento, principais clientes e concorrentes foram relacionadas e são apresentadas na tabela 12 .

Tabela 12 - Características das empresas estudadas.

\begin{tabular}{|c|c|c|c|c|c|c|c|c|c|}
\hline \multirow{2}{*}{ Características } & \multicolumn{9}{|c|}{ Empresas } \\
\hline & $\mathbf{A}$ & B & $\mathbf{C}$ & D & $\mathbf{E}$ & $\mathbf{F}$ & $\mathbf{G}$ & $\mathbf{H}$ & I \\
\hline $\begin{array}{l}\text { Número } \\
\text { aproximado de } \\
\text { funcionários }\end{array}$ & 120 & 80 & 98 & 2000 & 650 & 80 & 85 & 174 & 300 \\
\hline $\begin{array}{l}\text { Faturamento } \\
\text { (em milhões de } \\
\text { reais em 2004) }\end{array}$ & 4 & 10 & $\begin{array}{c}\text { não } \\
\text { forneceu }\end{array}$ & 900 & 200 & $\begin{array}{c}\text { não } \\
\text { forneceu }\end{array}$ & 15 & 60 & 170 \\
\hline $\begin{array}{l}\text { Principais } \\
\text { Clientes }\end{array}$ & $\begin{array}{c}\text { Empresa } \\
\mathrm{E}\end{array}$ & $\begin{array}{l}\text { Grandes } \\
\text { produtores } \\
\text { de gado }\end{array}$ & $\begin{array}{c}\text { Empresa } \\
\mathrm{E}\end{array}$ & $\begin{array}{c}\text { Grandes } \\
\text { cooperativas }\end{array}$ & $\begin{array}{l}\text { Grandes } \\
\text { revendas }\end{array}$ & $\begin{array}{l}\text { Grandes } \\
\text { revendas }\end{array}$ & $\begin{array}{l}\text { Grandes } \\
\text { revendas }\end{array}$ & $\begin{array}{l}\text { Grandes } \\
\text { revendas }\end{array}$ & $\begin{array}{l}\text { Grandes } \\
\text { revendas }\end{array}$ \\
\hline $\begin{array}{l}\text { Principais } \\
\text { Concorrentes }\end{array}$ & $\begin{array}{c}\text { Empresa } \\
\text { G }\end{array}$ & $\begin{array}{c}\text { Empresa } \\
\text { G e outras }\end{array}$ & $\begin{array}{c}\text { Empresa } \\
\text { A }\end{array}$ & $\begin{array}{l}\text { Empresas F, } \\
\text { I e outras }\end{array}$ & outras & $\begin{array}{c}\text { Empresas } \\
\text { D e I }\end{array}$ & $\begin{array}{c}\text { Empresas } \\
\text { A, B e } \\
\text { outras }\end{array}$ & outras & $\begin{array}{c}\text { Empresas } \\
\mathrm{D}, \mathrm{F} \mathrm{e} \\
\text { outras }\end{array}$ \\
\hline
\end{tabular}


Como se pode notar, a pesquisa foi feita em empresas com portes variados. Segundo o Sebrae (2005), as empresas podem ser classificadas como:

Micro empresa: de 1 a 19 funcionários;

$>$ Pequena empresa: de 20 a 99 funcionários;

$>$ Média empresa: de 100 a 499 funcionários; e

$>$ Grande empresa: acima de 499 funcionários.

Utilizando esta classificação, pode-se ver que esta pesquisa possui uma boa distribuição entre as classes, como mostra a tabela 13.

Tabela 13 - Classificação das empresas pesquisadas

\begin{tabular}{c|c}
\hline \multicolumn{2}{c}{ Classificação das empresas } \\
\hline Porte & Quantidade apresentada na pesquisa \\
\hline Micro & 0 \\
Pequena & 4 \\
Média & 3 \\
Grande & 2 \\
\hline Total & $\mathbf{9}$ \\
\hline
\end{tabular}

A tabela 12 informa os principais clientes das empresas estudadas, sendo que duas delas (A e C) são parceiras da empresa E. A maioria delas, cerca de 5, vendem seus produtos para grandes revendas, podendo-se notar que este tipo de atuação no mercado independe do porte da empresa. Apenas duas empresas atuam diferentemente: a empresa $\mathrm{B}$ vende seus produtos diretamente para seus clientes, que são os grandes produtores de gado e a empresa $\mathrm{D}$ atua através de grandes cooperativas.

Quanto à concorrência, as empresas A, B e G concorrem entre si, porém B e $\mathrm{G}$ têm outros concorrentes, dependendo do tipo de produto. As empresas D, F e I também competem entre si, sendo que as empresas D e I têm outros concorrentes pela variedade de produtos.

Quanto aos projetos Lean, as empresas estudadas levantaram os principais motivos internos e externos para a utilização de Produção Enxuta. 


\section{Principais fatores motivadores à implementação de Produção Enxuta}

Foram levantados e identificados, junto com os entrevistados, os principais fatores internos e externos motivadores para a mudança. No quadro 7 estão relacionados estes fatores com as empresas estudadas.

Quadro 7 - Fatores motivacionais para a mudança

\begin{tabular}{|c|c|c|c|c|c|c|c|c|c|}
\hline \multicolumn{10}{|c|}{ Fatores motivacionais para a mudança } \\
\hline \multirow[b]{2}{*}{ Fatores Internos } & \multicolumn{9}{|c|}{ Empresas } \\
\hline & A & B & $\mathrm{C}$ & D & $\mathrm{E}$ & $\mathbf{F}$ & G & $\mathrm{H}$ & I \\
\hline Baixa produtividade & $\mathrm{X}$ & & & & $\mathrm{X}$ & & & $\mathrm{X}$ & $\mathrm{X}$ \\
\hline Grande quantidade de desperdícios & & $\mathrm{X}$ & & & $\mathrm{X}$ & & $\mathrm{X}$ & $\mathrm{X}$ & \\
\hline Dificuldade de informações confiáveis & & & $\mathrm{X}$ & & & $\mathrm{X}$ & & & \\
\hline Sistema produtivo desorganizado e sem controle & & & & & & $\mathrm{X}$ & & & \\
\hline Dificuldade de fluxo de caixa & & & & & $\mathrm{X}$ & & $\mathrm{X}$ & & \\
\hline Custos produtivos elevados & & & & & & & & $\mathrm{X}$ & \\
\hline Fatores Externos & & & & & & & & & \\
\hline Parceira na cadeia produtiva & $\mathrm{X}$ & & $\mathrm{X}$ & & & & & & \\
\hline Benchmarking & & $\mathrm{X}$ & & & & & $\mathrm{X}$ & $\mathrm{X}$ & \\
\hline Exigência do mercado consumidor por melhores produtos & & & $\mathrm{X}$ & $\mathrm{X}$ & & & & & \\
\hline Demanda alta & $\mathrm{X}$ & & & & $\mathrm{X}$ & & $\mathbf{X}$ & & $\mathrm{X}$ \\
\hline
\end{tabular}

Os principais fatores internos motivacionais foram a percepção de baixa produtividade e a grande quantidade de desperdícios encontrada no processo produtivo, relatados em 4 empresas. Em seguida foram mencionados: dificuldade no fluxo de caixa e de informações confiáveis. E por fim, custos de produção elevados e sistema produtivo desorganizado e sem controle. Note que custos, normalmente associado às expectativas das empresas, não foi um fator interno crítico determinante para a maioria das empresas.

Quanto aos fatores externos motivadores da mudança, ilustrados no quadro 7, o mais citado foi a necessidade de atender melhor o mercado consumidor, seguido pelo o benchmarking realizado na empresa D, que foi pioneira no setor no Brasil na implementação de Produção Enxuta. Três empresas estudadas visitaram a empresa D e conheceram o projeto e seus resultados alcançados, vendo que era possível utilizar Produção Enxuta no setor. 
Os outros fatores externos foram: a parceria existente entre as empresas da cadeia produtiva e a exigência do mercado consumidor por melhores produtos.

Após a identificação de fatores motivadores internos e externos, cada empresa precisou fazer investimentos nos seus projetos Lean.

\section{Investimentos necessários à implementação de Produção Enxuta}

Todas as empresas estudadas investiram nos seus projetos, se não em equipamentos e consultoria, pelo menos em tempo. Todas contaram com a ajuda de terceiros para a implementação do projeto. No caso de consultorias, todas as empresas utilizaram, sendo que duas delas contaram com apoio do Lean Institute Brasil, como mostra o quadro 8.

Quadro 8 - Apoio externo no projeto Lean

\begin{tabular}{|c|c|c|c|c|c|c|c|c|c|}
\hline \multicolumn{10}{|c|}{ Apoio externo } \\
\hline & \multicolumn{9}{|c|}{ Empresas } \\
\hline & A & B & $\mathrm{C}$ & D & $\mathrm{E}$ & $\mathrm{F}$ & G & $\mathrm{H}$ & I \\
\hline Uso de consultoria & $\mathrm{X}$ & $\mathrm{x}$ & $\mathrm{X}$ & & $\mathrm{X}$ & $\mathrm{X}$ & $\mathrm{X}$ & $\mathrm{X}$ & \\
\hline Apoio do Lean Institute Brasil & & & & $\mathrm{X}$ & & & & & $\mathrm{X}$ \\
\hline
\end{tabular}

No caso das empresas A e C, o pagamento da consultoria foi feito pela empresa $\mathrm{E}$, que é parceira e neste caso foi a única que investiu nos seus fornecedores.

Além de investimentos financeiros com terceiros, algumas empresas estudadas investiram em equipamentos com foi o caso das empresas D e E, esta última mencionou a compra de material para fazer pallets, carrinhos, etc., o que também ocorreu com a empresa $\mathrm{H}$.

Os demais investimentos como treinamento, tempo, mão-de-obra deslocada para o projeto, visitas, viagens e materiais didáticos não foram quantificados ou foram considerados irrisórios pelos entrevistados.

De maneira geral, o sentimento dos entrevistados é de que efetivamente foram feitos investimentos, mas estes foram considerados relativamente baixos, em relação ao retorno obtido com o projeto. Cabe ressaltar que as entrevistas foram feitas com os responsáveis dos projetos e que dessa forma tendem a apresentar uma visão otimista.

Cada empresa estudada utilizou uma metodologia de atuação e 
implementação do projeto.

\section{Estratégias de implementação de Produção Enxuta}

Os projetos Lean iniciaram em períodos diferentes nas empresas estudadas. Adotando como base o mês de junho de 2005, o tempo médio decorrido desde o início dos projetos nas empresas estudadas foi um pouco acima de 20 meses, sendo o menor tempo de 8 meses na empresa $\mathrm{B}$ e o maior tempo na empresa $\mathrm{D}$, com aproximadamente 5 anos, como mostra o quadro 9.

\begin{tabular}{|c|c|c|c|c|c|c|c|c|c|}
\hline \multicolumn{10}{|c|}{ Características dos projetos Lean } \\
\hline \multirow{2}{*}{ Características } & \multicolumn{9}{|c|}{ Empresas } \\
\hline & A & $\mathrm{B}$ & $\mathrm{C}$ & $\mathrm{D}$ & $\mathrm{E}$ & F & G & H & I \\
\hline $\begin{array}{l}\text { Tempo de } \\
\text { desenvolvimento e } \\
\text { implementação }\end{array}$ & $\begin{array}{c}9 \\
\text { mese } \\
\text { s }\end{array}$ & $\begin{array}{c}8 \\
\text { mese } \\
\text { s }\end{array}$ & $\begin{array}{c}11 \\
\text { mese } \\
\mathrm{s}\end{array}$ & $\begin{array}{c}5 \\
\text { ano } \\
\mathrm{s}\end{array}$ & $\begin{array}{c}2 \\
\text { anos } \\
\text { e } 4 \\
\text { mese } \\
\text { s }\end{array}$ & $\begin{array}{l}1 \text { ano } \\
\text { e } 3 \\
\text { mese } \\
\text { s }\end{array}$ & $\begin{array}{c}10 \\
\text { mese } \\
\mathrm{s}\end{array}$ & $\begin{array}{l}1 \text { ano } \\
\text { e } 7 \\
\text { mese } \\
\text { s }\end{array}$ & $\begin{array}{c}2 \\
\text { ano } \\
\mathrm{s} \mathrm{e} \\
1 \\
\text { mês }\end{array}$ \\
\hline Implementação Piloto & $\mathrm{X}$ & $\mathrm{x}$ & & $\mathrm{X}$ & & $\mathrm{X}$ & $\mathrm{x}$ & & $\mathrm{X}$ \\
\hline $\begin{array}{l}\text { Implementação } \\
\text { Programática } \\
\text { Implementação } \\
\text { Prototipal }\end{array}$ & & & $\mathrm{X}$ & & $\mathrm{X}$ & & & $\mathrm{X}$ & \\
\hline
\end{tabular}

Quanto a metodologia de implementação, adotada pelas empresas, podese verificar que foram utilizadas implementações do tipo piloto, programática e prototipal.

Cerca de $67 \%$ das empresas estudadas fizeram uso da implementação piloto como foi o caso das empresas A, B, D, F, G e I, sendo que 4 dessas (A, B, F e G) utilizaram consultoria externa para a implementação. As 2 restantes contaram com o Lean Institute Brasil, que oferece programas de apoio as empresas que estejam implantando Produção Enxuta. Sua metodologia de trabalho consiste em fazer uma implementação piloto e posteriormente expandir para outros produtos ou áreas (LEAN INSTITUTE BRASIL, 2005).

Apenas a empresa $\mathrm{C}$ utilizou a implementação programática e as empresas E e H usaram a implementação prototipal.

O quadro 12 aborda as principais medidas adotadas pelas empresas, quando se iniciou o projeto Lean. Estas medidas refletiram os passos que as empresas 
adotaram para a implementação do projeto e ocorreram de forma particular em cada caso. No quadro 10, a ordem com que elas aparecem não reflete a seqüência utilizada pelas empresas, e sim se ocorreram ou não. A sequiência de medidas tomadas por cada empresa está no capítulo 4.

Quadro 10 - Principais medidas tomadas

\begin{tabular}{|c|c|c|c|c|c|c|c|c|c|}
\hline \multicolumn{10}{|c|}{ Principais medidas tomadas com o início do projeto Lean } \\
\hline \multirow{2}{*}{ Medidas adotadas } & \multicolumn{9}{|c|}{ Empresas } \\
\hline & A & B & $\mathrm{C}$ & D & $\mathrm{E}$ & F & G & H & I \\
\hline Formação de equipe & $\mathrm{x}$ & $\mathrm{x}$ & $\mathrm{x}$ & $\mathrm{x}$ & $\mathrm{x}$ & $\mathrm{x}$ & $\mathrm{x}$ & $\mathrm{x}$ & $\mathrm{x}$ \\
\hline Divisão da equipe & & $\mathrm{x}$ & & & & & & & $\mathrm{x}$ \\
\hline Treinamento da equipe & & & $\mathrm{x}$ & $\mathrm{x}$ & $\mathrm{x}$ & $\mathrm{X}$ & $\mathrm{x}$ & $\mathrm{x}$ & $\mathrm{x}$ \\
\hline Treinamento de funcionários específicos & & & & $\mathrm{x}$ & $\mathrm{x}$ & & & & \\
\hline Treinamento da diretoria & & & $\mathrm{x}$ & & & & & & \\
\hline Treinamento de todos os funcionários & $\mathrm{x}$ & $\mathrm{x}$ & & & $\mathrm{x}$ & & $\mathrm{x}$ & $\mathrm{x}$ & \\
\hline Treinamento de fornecedores & & & & & $\mathrm{x}$ & & & & \\
\hline
\end{tabular}

Das 6 empresas que utilizaram a implementação piloto, todas elas formaram uma equipe de trabalho do projeto, porém 2 delas (B e I) dividiram esta equipe em grupos menores de trabalho. Esta divisão segundo os entrevistados visou a abordagens de vários problemas ao mesmo tempo.

As empresas A, B e $\mathrm{G}$ treinaram todos os funcionários, sendo que a empresa $G$ treinou primeiramente a equipe. As empresas D, F e I treinaram somente a equipe de trabalho, com exceção da empresa D que também treinou alguns funcionários específicos de setores.

A empresa $\mathrm{C}$ tomou as seguintes medidas respectivamente: formação de uma equipe, treinamento para ela e para a diretoria e, posteriormente a implementação do projeto. Por ter optado pela implementação programática era de se esperar que houvesse um treinamento para todos os funcionários, já que a implementação do projeto seria feita em toda a empresa. O tempo de implementação deste projeto é de 11 meses, e este tipo de implementação inicial tende a ter resultado de longo prazo, como citado anteriormente. Pode ser que a empresa $\mathrm{C}$ ainda faça o treinamento em todos os funcionários.

Nas empresas E e H que utilizaram a implementação prototipal, as medidas tomadas foram parecidas (formação da equipe, treinamento da equipe, treinamento de todos funcionários). Porém a empresa E treinou também funcionários de 
setores específicos. Uma iniciativa encontrada somente na empresa E foi a extensão do projeto Lean para seus fornecedores, viabilizando o projeto para sua cadeia produtiva.

Com a implementação dos projetos Lean começaram a aparecer alguns problemas relatados pelos entrevistados.

\section{$>$ Principais problemas encontrados nas implementações}

Quase todas as empresas estudadas relataram problemas durante a implementação do projeto, porém não houve nenhum problema particularmente significativo. Os principais problemas encontrados estão relacionados no quadro 11.

Quadro 11 - Principais problemas encontrados

\begin{tabular}{|c|c|c|c|c|c|c|c|c|c|}
\hline \multirow[b]{3}{*}{ Problemas encontrados } & en & se & 201 & & & & & & \\
\hline & \multicolumn{9}{|c|}{ Empresas } \\
\hline & A & B & $\mathrm{C}$ & $\mathrm{D}$ & $\mathrm{E}$ & $\mathrm{F}$ & G & $\mathrm{H}$ & I \\
\hline Sazonalidade da demanda & $\mathrm{X}$ & & & & & & & & \\
\hline Resistência à mudanças & & $\mathrm{X}$ & $\mathrm{X}$ & & & & $\mathrm{X}$ & $\mathrm{x}$ & \\
\hline Falta de dados confiáveis & & & $\mathrm{X}$ & & & $\mathrm{X}$ & & & \\
\hline Morosidade & & & $\mathrm{X}$ & & $\mathrm{X}$ & $\mathrm{X}$ & & & \\
\hline Trabalho paralelo do projeto com o sistema de lote & & & & & & & $\mathrm{X}$ & & \\
\hline Falta de treinamento & & & & & & & & $\mathrm{X}$ & \\
\hline Falta de tempo & & & & & & & & $\mathrm{x}$ & \\
\hline Falta de envolvimento & & & & & & & & & $\mathrm{X}$ \\
\hline
\end{tabular}

O entrevistado da empresa A caracterizou como principal problema a sazonalidade da demanda, justamente porque ela produz, para a empresa parceira $\mathrm{E}$, produtos destinados à safra. Quando o projeto foi iniciado ( 9 meses atrás), os produtos da empresa parceira E estavam em alta demanda. Mas após o período de safra, as vendas diminuíram e o projeto sofreu uma interrupção temporária, caracterizando uma dificuldade para a empresa nesta fase do projeto, que precisou procurar outras empresas parceiras, como citado no capítulo 4, para não demitir seus funcionários e estabilizar sua produção. Porém estas empresas não utilizam produção enxuta e demandam grandes lotes de produtos, o que pode dificultar a conciliação entre o projeto Lean e as outras empresas.

A resistência à mudanças foi o problema mais citado pelas empresas, cerca de 4 delas o apontaram (B, C, G e H). Nestas empresas o treinamento dado pode ter sido feito superficialmente e/ou não dirigido as pessoas certas. Na empresa B não 
houve um treinamento específico para a equipe do projeto, como mostra o quadro 13. A empresa C tinha optado por uma estratégia de implementação programática (quadro 11), mas só treinou a equipe e a diretoria, como forma de o projeto ganhar credibilidade e não levaram em consideração os outros funcionários da empresa, que não sabiam o porquê das mudanças ocorridas. Nas empresas $\mathrm{G}$ e $\mathrm{H}$, as resistências foram apresentadas durante o início da implementação do projeto, foi quando se decidiu dar um treinamento para todos os funcionários. Espera-se que o treinamento possa eliminar estas resistências.

A falta de dados confiáveis para o projeto foi apontado como problema nas empresas $\mathrm{C}$ e $\mathrm{F}$, que consequentemente acabou gerando certa morosidade no mesmo. Já o entrevistado da empresa $E$ atribuiu o maior problema como sendo a morosidade do entendimento dos conceitos por parte dos gerentes e supervisores, o que pode ser atribuído a um treinamento deficiente.

Como a empresa $\mathrm{G}$ optou pela implementação piloto, ela precisou fazer com que seus funcionários ficassem trabalhando no projeto Lean e em paralelo trabalhando com o sistema produtivo antigo, o que acabou gerando certa dificuldade de gerenciamento.

A falta de treinamento foi apontada como problema na empresa $\mathrm{H}$, pois o entrevistado admitiu que no início do projeto Lean, o treinamento foi passado somente aos funcionários pertencentes à equipe do projeto. Porém quando ocorreu a primeira implementação do projeto, ficou constatado que havia a necessidade de se treinar todos os funcionários envolvidos, já que eles estavam resistentes às mudanças. A falta de tempo para dedicação ao projeto foi outro problema comentado, devido à alta produção no período.

A empresa I apontou como principal problema a falta de envolvimento dos funcionários. A entrevistada comentou que a princípio o projeto Lean ficou concentrado na equipe e na diretoria e os funcionários do chão-de-fábrica não tomavam decisões e não participavam das reuniões. No momento da implementação do projeto apareceram divergências devido à falta de envolvimento. Este problema foi sanado com a divisão da equipe, onde foi criada uma função de team líder, que criou um elo entre as duas partes - a equipe e o chão-de-fábrica. Isso comprova o comentário de Hines, Holweg e Rich (2004), de que muitas implementações são focadas nas práticas e geralmente negligenciam os aspectos humanos, que estão na essência do modelo de Produção Enxuta. 
Já a empresa D não relatou um grande problema, e o entrevistado afirmou que isto se deu devido a participação do presidente da empresa, durante todo o projeto. Segundo Feld (2001) o envolvimento da presidência é importante porque mostra como as mudanças são necessárias e faz com que os funcionários tornem-se engajados no projeto.

Com a implementação dos projetos Lean, as empresa estudadas sofreram algumas mudanças. Esta pesquisa procurou mostrar mudanças envolvendo os seguintes elementos: sistema de custeio, medição de desempenho de produção de máquinas por operador, sistema de desempenho de setup e takt time.

\section{Mudanças ocorridas nas empresas após a implementação de}

\section{Produção Enxuta}

A primeira mudança estudada foi quanto ao sistema de custeio de produtos. Das empresas estudadas, 7 delas (A, B, C, D, E, F e G) não alteraram a forma de como era feito este custeio antes do projeto Lean. Somente duas delas (H e I) estavam, no momento da entrevista, fazendo alterações resultantes do projeto no sistema de custeio.

De uma maneira geral pode-se dizer que as empresas estudadas não deram ênfase em relação a este sistema, independente da metodologia de implementação e do tempo do projeto. Segundo Battaglia (2003) a contabilidade Lean deve ser entendida como ferramenta para o aprendizado organizacional na busca por estados futuros cada vez melhores, mas trata-se de um conceito ainda em construção, cujas aplicações práticas são muito incipientes. Para Maskell e Baggaley (2004) as empresas, que utilizam Produção Enxuta e tentam usar sistemas tradicionais de custos, enfrentam conflitos porque estes sistemas são baseados na economia de escala fornecida pela produção em massa. As empresas estudadas ainda não estão sensíveis a esta problemática, o que pode atrapalhar o andamento dos projetos.

A segunda mudança estudada foi a medição de desempenho de produção de máquina por operador. Como se pôde constatar, cerca de $78 \%$ das empresas estudadas (A, B, C, D, F, G e H) não possuem esta medição e mesmo com a implementação do projeto Lean ela não foi abordada. Apenas duas empresas (E e I) possuem medidas para avaliarem o desempenho de produção de máquina por operador. A empresa E possui um índice de produtividade geral, chamado GPD, o qual é formado pelo faturamento - gasto (suprimentos), relacionado à maquinas dividido pelos 
encargos, relacionado a pessoas. Este índice triplicou em um ano, era cerca de 1,00 em 2003 e passou para 3,00 em 2004. Já na empresa I existe um indicador chamado máquina equivalente por homem. Depois do projeto Lean, este índice aumentou em mais de seis vezes (1,95 para 12). Detalhes nos apêndices E e I.

Da mesma maneira que nos itens anteriores, o sistema de medição de desempenho de setup também não era medido nas empresas estudadas. Somente o entrevistado da empresa E relatou um trabalho feito no processo de solda, onde se conseguiu reduzir o tempo de setup em seis vezes (era 30 minutos e passou para 5 minutos).

Quando foram abordados sobre o takt time, a maioria dos entrevistados relatou que as empresas conseguiram responder melhor às demandas do mercado, diminuindo o takt time, como pode se ver no capítulo 4. Porém o setor agrícola 2005 passou por uma crise financeira decorrente da falta de empréstimos bancários e crise de mercado, devido à baixa do preço da soja no mercado internacional, o que acabou prejudicando as vendas de máquinas e implementos agrícolas.

As empresas estudadas foram visitadas no primeiro semestre de 2005 e os entrevistados comentaram que ainda estavam em alta demanda, com exceção da empresa $\mathrm{H}$ que relatou a queda da sua demanda. Portanto, os takt times levantados nos roteiros refletem o estado atual do momento da entrevista.

Um outro aspecto abordado nesta pesquisa foram as práticas utilizadas

\section{Práticas utilizadas nas empresas estudadas}

Durante as visitas e entrevistas realizadas nas empresas, pôde-se constatar a importância e a presença de cada prática de Produção Enxuta, referenciadas no capítulo 2. Através do roteiro de entrevista procurou-se aferir qual o nível de importância que cada empresa dava a cada prática e qual o nível de utilização real (presença) de cada uma nos projetos Lean, utilizando os critérios fornecidos no capítulo 4.

Primeiramente será abordado o aspecto da importância que cada entrevistado dava àquela determinada prática de Produção Enxuta e em seguida se esta prática tinha sido implementada no projeto, e se sim, o quanto ela contribuiu. Os resultados quanto a importância das práticas obtidos nas entrevistas estão na tabela 14 a seguir. 
Tabela 14 - Importância das Práticas de Produção Enxuta

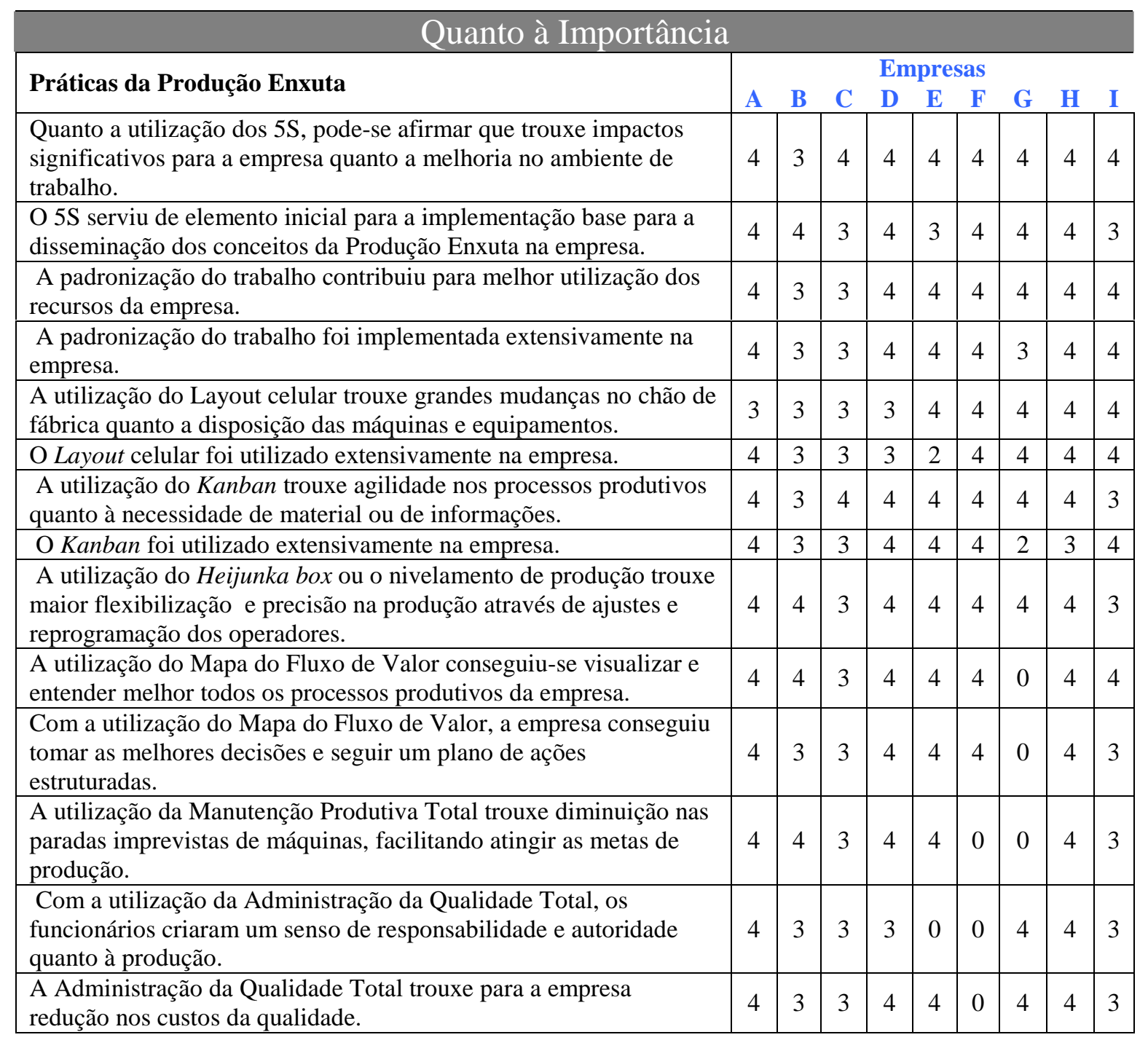

Em seguida os entrevistados responderam as mesmas afirmações, porém sob a ótica de implementação das práticas, ou seja, se elas foram utilizadas ou não e como elas tinham contribuído para o projeto Lean. Os resultados quanto a presença das práticas obtidos nas entrevistas estão na tabela 15 . 
Tabela 15 - Aplicação das Práticas de Produção Enxuta

\begin{tabular}{|c|c|c|c|c|c|c|c|c|c|}
\hline \multicolumn{10}{|l|}{ Quanto à aplicação } \\
\hline \multirow[b]{2}{*}{ Práticas da Produção Enxuta } & \multicolumn{9}{|c|}{ Empresas } \\
\hline & A & $\mathbf{B}$ & $\mathrm{C}$ & D & $\mathbf{E}$ & $\mathbf{F}$ & G & $\mathrm{H}$ & I \\
\hline $\begin{array}{l}\text { Quanto a utilização dos } 5 \mathrm{~S} \text {, pode-se afirmar que trouxe impactos } \\
\text { significativos para a empresa quanto a melhoria no ambiente de } \\
\text { trabalho. }\end{array}$ & 4 & 3 & 4 & 4 & 4 & 0 & 4 & 4 & 4 \\
\hline $\begin{array}{l}\text { O 5S serviu de elemento inicial para a implementação base para a } \\
\text { disseminação dos conceitos da Produção Enxuta na empresa. }\end{array}$ & 4 & 4 & 3 & 4 & 2 & 0 & 4 & 4 & 2 \\
\hline $\begin{array}{l}\text { A padronização do trabalho contribuiu para melhor utilização dos } \\
\text { recursos da empresa. }\end{array}$ & 4 & 3 & 0 & 4 & 4 & 3 & 0 & 0 & 4 \\
\hline $\begin{array}{l}\text { A padronização do trabalho foi implementada extensivamente na } \\
\text { empresa. }\end{array}$ & 3 & 2 & 0 & 4 & 3 & 3 & 0 & 0 & 3 \\
\hline $\begin{array}{l}\text { A utilização do Layout celular trouxe grandes mudanças no chão de } \\
\text { fábrica quanto a disposição das máquinas e equipamentos. }\end{array}$ & 3 & 3 & 3 & 3 & 3 & 4 & 4 & 0 & 3 \\
\hline O Layout celular foi utilizado extensivamente na empresa. & 2 & 3 & 3 & 3 & 2 & 3 & 4 & 0 & 3 \\
\hline $\begin{array}{l}\text { A utilização do Kanban trouxe agilidade nos processos produtivos } \\
\text { quanto à necessidade de material ou de informações. }\end{array}$ & 4 & 4 & 4 & 4 & 3 & 4 & 4 & 4 & 3 \\
\hline O Kanban foi utilizado extensivamente na empresa. & 3 & 3 & 3 & 4 & 4 & 4 & 2 & 4 & 4 \\
\hline $\begin{array}{l}\text { A utilização do Heijunka box ou o nivelamento de produção trouxe } \\
\text { maior flexibilização e precisão na produção através de ajustes e } \\
\text { reprogramação dos operadores. }\end{array}$ & 3 & 0 & 0 & 4 & 3 & 3 & 0 & 0 & 0 \\
\hline $\begin{array}{l}\text { A utilização do Mapa do Fluxo de Valor conseguiu-se visualizar e } \\
\text { entender melhor todos os processos produtivos da empresa. }\end{array}$ & 4 & 0 & 4 & 4 & 4 & 4 & 0 & 4 & 4 \\
\hline $\begin{array}{l}\text { Com a utilização do Mapa do Fluxo de Valor, a empresa conseguiu } \\
\text { tomar as melhores decisões e seguir um plano de ações } \\
\text { estruturadas. }\end{array}$ & 4 & 0 & 4 & 4 & 4 & 3 & 0 & 4 & 3 \\
\hline $\begin{array}{l}\text { A utilização da Manutenção Produtiva Total trouxe diminuição nas } \\
\text { paradas imprevistas de máquinas, facilitando atingir as metas de } \\
\text { produção. }\end{array}$ & 0 & 0 & 0 & 4 & 0 & 0 & 0 & 0 & 0 \\
\hline $\begin{array}{l}\text { Com a utilização da Administração da Qualidade Total, os } \\
\text { funcionários criaram um senso de responsabilidade e autoridade } \\
\text { quanto à produção. }\end{array}$ & 0 & 0 & 0 & 4 & 3 & 0 & 4 & 0 & 0 \\
\hline $\begin{array}{l}\text { A Administração da Qualidade Total trouxe para a empresa } \\
\text { redução nos custos da qualidade. }\end{array}$ & 0 & 0 & 0 & 4 & 3 & 0 & 4 & 0 & 0 \\
\hline
\end{tabular}

A partir das tabelas 14 e 15 foi montada uma outra tabela (tabela 16), relacionando as médias das respostas dos entrevistados, quanto à importância e aplicação das práticas. Aquelas práticas que tinham duas afirmações relacionadas foram somadas e dividas de forma igualitária.

Tabela 16 - Práticas de Produção Enxuta- Importância e Aplicação.

Práticas de Produção Enxuta - Importância e Aplicação

\section{Práticas}

$5 \mathrm{~S}$

Padronização do trabalho

Layout celular

Kanban

\section{Importância Aplicação Diferença}

5,72

5,61
4,94

0,78

3,44

4,16

5,50 


\section{Práticas de Produção Enxuta - Importância e Aplicação}

\begin{tabular}{|l|c|c|c|}
\hline \multicolumn{1}{|c|}{ Práticas } & Importância & Aplicação & Diferença \\
Heijunka box & 3,77 & 1,44 & 2,33 \\
Mapa do Fluxo de Valor & 5,05 & 4,55 & 0,50 \\
Manutenção Produtiva Total & 2,88 & 0,44 & 2,44 \\
Administração da Qualidade Total & 4,27 & 1,83 & 2,44 \\
\hline
\end{tabular}

Como se pode observar, na opinião dos entrevistados, a prática que tem uma maior importância é $5 \mathrm{~S}$, porém a ênfase dos projetos Lean foi maior na aplicação de kanban.

O kanban foi a única prática em que a importância e a aplicação obtiveram a mesma pontuação. Já a padronização do trabalho, o heijunka box, a administração da qualidade total e a manutenção produtiva total foram as práticas nas quais se teve uma maior diferença entre importância e aplicação, como pode ser observado no gráfico 1 abaixo.

\section{Práticas de Produção Enxuta - Importância e Aplicação}

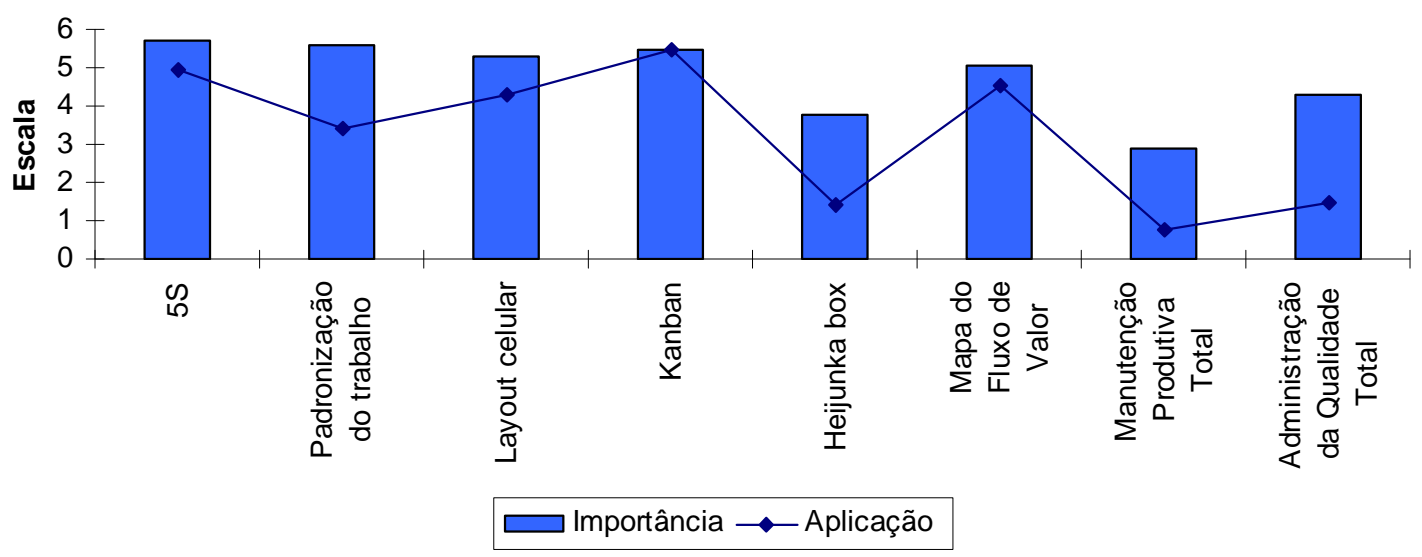

Gráfico 1 - Práticas de Produção Enxuta- Importância e Aplicação

A aplicação das práticas nos projetos Lean nas empresas estudadas é apresentada no gráfico 2 , no qual se pode observar que a prática mais aplicada é o kanban, implementado em todas as empresas, seguido pelos 5S (8 empresas) e o layout celular. Logo em seguida, aparece o mapa do fluxo de valor (7 empresas). A padronização do trabalho foi encontrada em 6 empresas. O heijunka box é utilizado em 
4 empresas. A seguir a administração da qualidade total (3 empresas) e finalmente a manutenção produtiva total (1 empresa).

\section{Aplicação das Práticas nas empresas}

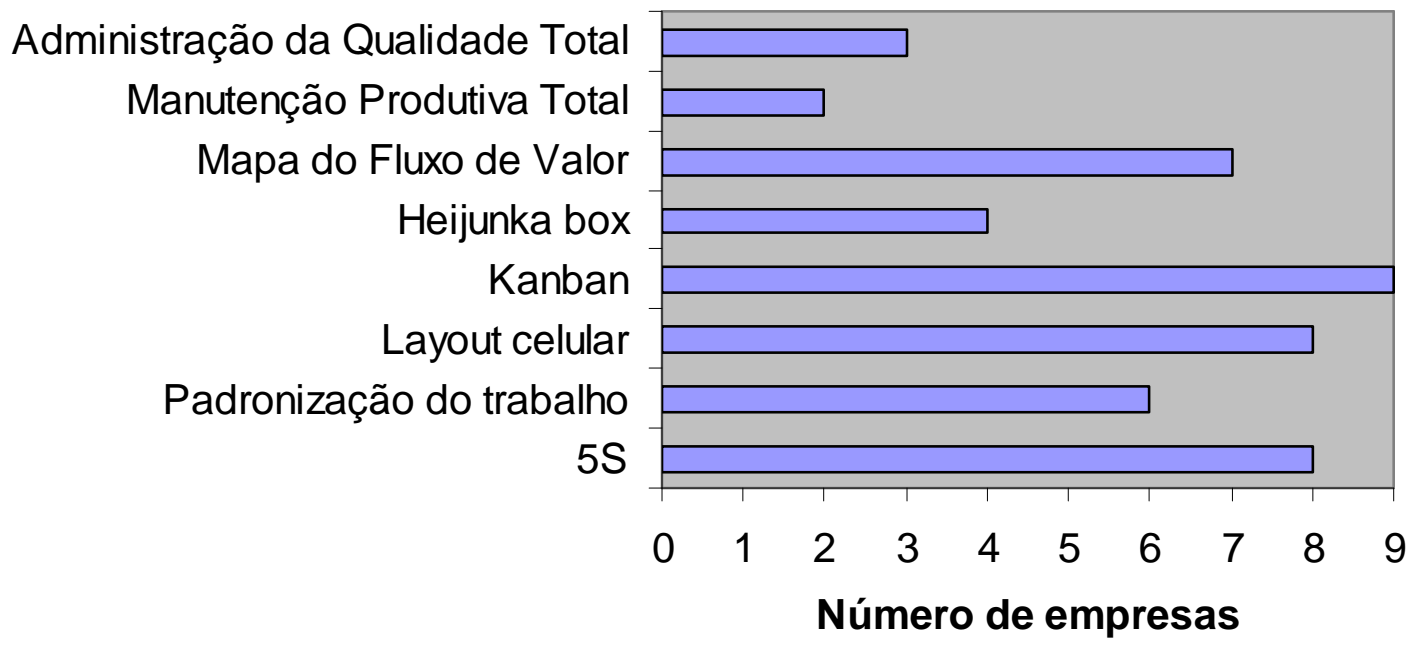

Gráfico 2 - Aplicação das práticas de Produção Enxuta.

As empresas estudadas apresentaram maior familiaridade com a prática do kanban. Vale destacar que as empresas A e B aplicaram primeiramente na família escolhida e depois estendeu para outras. Na empresa C, a aplicação do kanban estava na fase inicial de implementação. A empresa D apresenta certo grau de maturação em relação a esta prática, já que a mesma é aplicada desde o início do projeto Lean e foi, segundo o entrevistado, a primeira empresa no Brasil a utilizar o kanban no setor. Já nas empresas E e I o uso do kanban é datado antes do projeto Lean, porém havia má utilização da prática. Nas empresas F e G, seu uso ainda estava restrito a família piloto. $\mathrm{Na}$ empresa $\mathrm{H}$, que optou por uma implementação prototipal, houve implementação do kanban nas famílias escolhidas no projeto.

Quanto às condições gerais de trabalho, as empresas estudadas apresentaram um ambiente rudimentar e em muitas delas pôde-se observar que o chão da fábrica apresentava desnível, estava desgastado e sem pintura. Por isso mesmo os entrevistados tinham ciência da importância dos 5S, sua implementação total tornou-se difícil e em muitas delas o que se observou foi a implementação dos $2 \mathrm{~S}$ iniciais desta prática. Somente a empresa D se destacou das demais em termos de organização e higiene no ambiente de trabalho, por possuir um local limpo e bem organizado.

O layout celular foi utilizado em 8 empresas estudadas e foi constatado 
que na empresa A o layout celular foi utilizado somente na família piloto, já nas empresas B e C, embora também tenha optado pela implementação piloto, o layout celular acabou sendo implementado em toda a empresa. Na empresa D, pelo tempo do projeto (cerca de 5 anos), o layout celular esta presente na empresa toda, lá a montagem e submontagens de várias famílias se dá em layout celular e até fabricação das famílias de peças para as máquinas. A empresa E também implementou layout celular, porém o entrevistado afirmou que ele não deve ser implementado extensivamente na empresa, somente onde haja necessidade de se agruparem máquinas da mesma família. Nas empresas F, G e I, a implementação iniciou com a família piloto e se expandiu para a empresa toda.

A aplicação do mapa do fluxo de valor deu-se em 7 das 9 empresas. Na empresa A, F e I foi feito o mapeamento da família piloto. Já na empresa C o mapeamento foi feito em algumas famílias de produtos, o que também ocorreu nas empresas E e H. A empresa D começou o mapeamento pela família piloto e com a expansão do projeto Lean, o mapeamento englobou outras famílias.

A padronização do trabalho foi implementada nas empresas A, B, F e I através da família piloto e depois foi sendo expandida para outras no decorrer do projeto. A empresa $\mathrm{D}$ utilizou a mesma estratégia, porém como o tempo de projeto Lean, a padronização do trabalho está bem mais consolidada. Já na empresa E, que optou por uma implementação prototipal, fez um trabalho de disseminação da padronização do trabalho em toda a empresa, sendo formadas várias frentes de trabalho neste sentido.

O heijunka box foi utilizado em 4 empresas. Na ocasião da visita na empresa A foi verificado o uso desta prática, assim como nas empresas D, E e F que possuem vários quadros de programação e nivelamento de produção, como foi constatado em visita.

Foram feitos esforços de administração da qualidade total em 3 empresas. A empresa D mesmo apresentando um tempo comparativamente alto de implementação do projeto Lean, afirmou que ainda não se conseguiram grandes resultados com a qualidade nos aspectos levantados no roteiro de entrevista, acreditando ser necessário um trabalho maior para reforçá-la. As empresas E e G conseguiram melhorar o senso de responsabilidade dos funcionários e reduzir custos, estando satisfeita com os resultados.

Somente 1 empresa utilizou a manutenção produtiva total, sendo ela a empresa D. Isto é relativamente surpreendente, uma vez que para garantir os fluxos 
contínuos a manutenção produtiva total é considerada na literatura como prática fundamental.

Todas as práticas abordadas nesta pesquisa foram implementadas nas empresas, variando o número de implementações e o grau de intensidade de cada uma nos projetos.

Após o período de desenvolvimento e implementação dos projetos Lean (quadro 11), as empresas estudadas puderam sentir diferenças e apontar os resultados obtidos.

\section{Resultados obtidos nas empresas estudadas}

Os resultados alcançados pelas empresas refletem em como os entrevistados perceberam as mudanças ocorridas nas empresas após o período de desenvolvimento e implementação dos projetos Lean. Estes resultados estão apresentados na tabela 17.

Tabela 17 - Resultados obtidos nos projetos

\begin{tabular}{|c|c|c|c|c|c|c|c|c|c|c|c|c|}
\hline \multirow{2}{*}{ Resultados } & \multicolumn{9}{|c|}{ Empresas } & \multirow{2}{*}{ Somatória } & \multirow{2}{*}{$\begin{array}{l}\text { Número de } \\
\text { empresas que } \\
\text { responderam }\end{array}$} & \multirow{2}{*}{ Média } \\
\hline & A & B & $\mathrm{C}$ & $\mathrm{D}$ & $\mathrm{E}$ & $\mathbf{F}$ & G & $\mathbf{H}$ & I & & & \\
\hline Aumento da Produtividade & 4 & 3 & 3 & 4 & 4 & 4 & 3 & 4 & 4 & 33 & 9 & 3,7 \\
\hline $\begin{array}{l}\text { Aumento da Pontualidade } \\
\text { de entrega }\end{array}$ & 4 & 3 & 3 & 4 & 3 & 4 & 4 & 4 & 4 & 33 & 9 & 3,7 \\
\hline Redução do lead time & 4 & 3 & 0 & 4 & 3 & 4 & 4 & 4 & 4 & 30 & 8 & 3,8 \\
\hline $\begin{array}{l}\text { Redução dos custos de } \\
\text { fabricação }\end{array}$ & 3 & 0 & 0 & 4 & 3 & 0 & 0 & 0 & 0 & 10 & 3 & 3,3 \\
\hline Aumento do faturamento & 3 & 0 & 0 & 4 & 3 & 0 & 3 & 2 & 4 & 19 & 6 & 3,2 \\
\hline Aumento da lucratividade & 4 & 0 & 0 & 4 & 4 & 0 & 3 & 0 & 4 & 19 & 5 & 3,8 \\
\hline $\begin{array}{l}\text { Diminuição de matéria- } \\
\text { prima } \\
\text { Diminuição de material } \\
\text { em processo }\end{array}$ & 4 & $\begin{array}{l}3 \\
3 \\
\end{array}$ & $\begin{array}{l}3 \\
0\end{array}$ & 0 & 4 & 4 & $\begin{array}{l}4 \\
4 \\
\end{array}$ & $\begin{array}{l}4 \\
4 \\
\end{array}$ & $\begin{array}{l}0 \\
4 \\
\end{array}$ & $\begin{array}{l}26 \\
30 \\
\end{array}$ & $\begin{array}{l}7 \\
8 \\
\end{array}$ & $\begin{array}{l}3,7 \\
3,8 \\
\end{array}$ \\
\hline $\begin{array}{l}\text { Diminuição de produto } \\
\text { acabado }\end{array}$ & 0 & 3 & 0 & 3 & 4 & 4 & 4 & 0 & 0 & 18 & 5 & 3,6 \\
\hline $\begin{array}{l}\text { Redução da área de } \\
\text { produção }\end{array}$ & 3 & 4 & 3 & 4 & 4 & 4 & 4 & 4 & 0 & 30 & 8 & 3,8 \\
\hline $\begin{array}{l}\text { Redução de movimentação } \\
\text { de material e pessoas }\end{array}$ & 4 & 3 & 0 & 3 & 4 & 4 & 4 & 4 & 4 & 30 & 8 & 3,8 \\
\hline $\begin{array}{l}\text { Aumento de participação } \\
\text { no mercado consumidor }\end{array}$ & 4 & 0 & 0 & 2 & 4 & 0 & 3 & 0 & 4 & 17 & 5 & 3,4 \\
\hline
\end{tabular}




\begin{tabular}{|c|c|c|c|c|c|c|c|c|c|c|c|c|}
\hline \multicolumn{13}{|c|}{ Análise dos resultados } \\
\hline \multirow{2}{*}{ Resultados } & \multicolumn{9}{|c|}{ Empresas } & \multirow{2}{*}{ Somatória } & \multirow{2}{*}{$\begin{array}{l}\text { Número de } \\
\text { empresas que } \\
\text { responderam }\end{array}$} & \multirow{2}{*}{ Média } \\
\hline & A & B & $\mathrm{C}$ & D & $\mathrm{E}$ & F & G & $\mathbf{H}$ & I & & & \\
\hline $\begin{array}{l}\text { Mudanças culturais dos } \\
\text { funcionários }\end{array}$ & 4 & 3 & 3 & 4 & 3 & 3 & 3 & 4 & 4 & 31 & 9 & 3,4 \\
\hline $\begin{array}{l}\text { Influenciou a política de } \\
\text { vendas }\end{array}$ & 0 & 0 & 0 & 4 & 3 & 3 & 4 & 0 & 3 & 17 & 5 & 3,4 \\
\hline $\begin{array}{l}\text { Mudanças no } \\
\text { desenvolvimento do } \\
\text { produto }\end{array}$ & 0 & 0 & 0 & 0 & 3 & 3 & 4 & 0 & 0 & 10 & 3 & 3,3 \\
\hline $\begin{array}{l}\text { Aumentou a qualidade dos } \\
\text { produtos }\end{array}$ & 3 & 3 & 3 & 4 & 3 & 0 & 4 & 4 & 3 & 27 & 8 & 3,4 \\
\hline $\begin{array}{l}\text { Aumento no mix de } \\
\text { produtos }\end{array}$ & 2 & 0 & 0 & 4 & 3 & 0 & 0 & 3 & 4 & 16 & 5 & 3,2 \\
\hline $\begin{array}{l}\text { Influenciou os } \\
\text { fornecedores }\end{array}$ & 4 & 0 & 0 & 3 & 3 & 0 & 4 & 3 & 3 & 20 & 6 & 3,3 \\
\hline Aumentou os fornecedores & 2 & 2 & 0 & 2 & 3 & 0 & 3 & 2 & 2 & 16 & 7 & 2,3 \\
\hline Diminuiu os fornecedores & 2 & 2 & 0 & 3 & 2 & 0 & 2 & 2 & 0 & 13 & 6 & 2,2 \\
\hline $\begin{array}{l}\text { Alterou os fluxos de } \\
\text { informações }\end{array}$ & 4 & 3 & 3 & 4 & 3 & 4 & 4 & 4 & 3 & 32 & 9 & 3,6 \\
\hline
\end{tabular}

Pode-se notar que, as maiores somatórias (produtividade e pontualidade) estão relacionadas à produção. Já os aspectos financeiros e de custos (custos de fabricação, faturamento e lucratividade) tiveram somatórias menores. As somatórias relacionadas com a área de vendas (participação em mercado e política de vendas) apresentaram baixos números, o que também ocorreu com o desenvolvimento de produtos.

Estes dados mostraram que os projetos Lean, de uma maneira geral ficaram mais voltados para o chão-de-fábrica e negligeciaram aspectos finaneceiros, justamente porque não se houve maiores preocupações com as medições de desempenho.

Os entrevistados que responderam com o número 0 , foram aqueles que admitiram não ter medido ou porque não perceberam estas mudanças.

Considerando a somatória os resultados obtidos em cada projeto e levando em consideração apenas as afirmações respondidas pelos entrevistados, chegase a uma pontuação média de cada projeto, como pode ser visto na tabela 18. 
Tabela 18 - Análise dos projetos Lean

\begin{tabular}{|c|c|c|c|c|c|c|c|c|c|}
\hline \multicolumn{10}{|c|}{ Análise dos projetos Lean } \\
\hline \multirow{2}{*}{$\begin{array}{l}\text { Levando em } \\
\text { consideração } \\
\text { os resultados } \\
\text { obtidos } \\
\end{array}$} & \multicolumn{9}{|c|}{ Empresas } \\
\hline & A & B & $\mathrm{C}$ & $\mathrm{D}$ & $\mathrm{E}$ & F & G & $\mathbf{H}$ & I \\
\hline $\begin{array}{l}\text { Pontuação } \\
\text { Máxima }\end{array}$ & 62 & 38 & 21 & 67 & 70 & 45 & 68 & 52 & 54 \\
\hline $\begin{array}{l}\text { Número total } \\
\text { de afirmações }\end{array}$ & 21 & 21 & 21 & 21 & 21 & 21 & 21 & 21 & 21 \\
\hline $\begin{array}{l}\text { Número de } \\
\text { afirmações não } \\
\text { respondidas }\end{array}$ & 3 & 8 & 14 & 2 & 0 & 9 & 2 & 6 & 6 \\
\hline $\begin{array}{l}\text { Número de } \\
\text { afirmações } \\
\text { respondidas }\end{array}$ & 18 & 13 & 7 & 19 & 21 & 12 & 19 & 15 & 15 \\
\hline $\begin{array}{l}\text { Pontuação } \\
\text { Média }\end{array}$ & 3,4 & 2,9 & 3,0 & 3,5 & 3,3 & 3,8 & 3,6 & 3,5 & 3,6 \\
\hline $\begin{array}{l}\text { Metodologia } \\
\text { de } \\
\text { Implementação }\end{array}$ & Piloto & Piloto & Programática & Piloto & Prototipal & Piloto & Piloto & Prototipal & Piloto \\
\hline $\begin{array}{l}\text { Número de } \\
\text { práticas } \\
\text { adotadas }\end{array}$ & 6 & 4 & 4 & 8 & 7 & 5 & 4 & 3 & 5 \\
\hline
\end{tabular}

Somando estas pontuações médias de acordo com a metodologia adotada e dividindo pelo número de empresas que a adotaram, têm-se que a média de cada tipo de implementação. Neste caso, a média dos resultados obtidos para a implementação piloto foi de 3,5. Para a programática foi de 3,0 e a prototipal foi de 3,4.

Pode-se notar que as empresas que implementaram a metodologia piloto conseguiram uma média superior das demais, independente do tempo de implementação do projeto e da quantidade de práticas adotadas. 


\section{Capítulo 6 - Conclusões e Considerações Finais}

\subsection{Conclusões}

Este trabalho procurou montar um cenário de algumas implementações de Produção Enxuta no setor brasileiro de máquinas e implementos agrícolas, como parte de um dos objetivos do IFM (Instituto Fábrica do Milênio), no qual o grupo GMMO faz parte.

A amostra escolhida considerou aquelas empresas, que no período de desenvolvimento da pesquisa, estavam apresentando indícios de implementação de Produção Enxuta e/ou mostraram seus casos em eventos relacionados com o tema. Como pôde ser visto nos capítulos anteriores, a amostra é extremamente variada, tornando-se difícil o uso de métodos estatísticos quantitativos, pois as empresas pesquisadas apresentam características e tempos de implementação diferentes. Por isso, a ênfase das análises, realizadas no trabalho, foi qualitativa. Estas análises qualitativas foram suficientes para responder aos objetivos da pesquisa.

O que se pôde verificar, de uma maneira geral, é que os projetos Lean tiveram investimentos por parte das empresas. Os investimentos incluíram tempo, consultoria, equipamentos e outros não contabilizados. Embora os valores apresentados pelos entrevistados fossem bem diferentes entre si, todos consideraram os investimentos relativamente baixos em relação aos resultados alcançados pelo projeto.

Todas as empresas utilizaram algum tipo de metodologia de implementação, o que demonstra um cuidado por parte da empresa ao iniciar a implementação de uma nova filosofia e também a estruturação de um plano de ação. Neste aspecto, a pesquisa constatou uma maior predominância da implementação piloto entre as empresas estudadas. Esta estratégia de implementação é muito difundida entre alguns autores e os consultores do Lean Institute Brasil.

Quanto às práticas utilizadas, todas foram implementadas nos projetos 
estudados. Cabe ressaltar que em duas empresas (B e G) não foi feito o mapa do fluxo de valor, sendo que esta prática é considerada pela literatura geral como extremamente importante. Womack e Jones (1998) salientam a importância de mapear todo o processo produtivo da(s) família(s) de produto(s) como forma de identificar os desperdícios e garantir a produção puxada, que é um dos princípios da Produção Enxuta. O que se verificou também, em relação as práticas, é que alguns entrevistados responderam que determinada prática tinha importância para o projeto, mas que ela ainda não tinha sido implementada. Isso pode ter sido devido a falta de tempo suficiente de implementação do projeto, em alguns casos e/ou incongruência de prioridades no projeto.

Quanto aos resultados alcançados, verificou-se, de forma geral, uma melhora principalmente nos aspectos ligados ao chão-de-fábrica e uma não preocupação por parte das empresas em estarem aplicando medidores de desempenho para avaliarem melhor o projeto. Este aspecto pode atrapalhar o andamento destes projetos, pois alguns autores como Womack e Jones (1998), Feld (2001) e Rother e Shook (1998) salientam que quando se inicia uma implementação de Produção Enxuta é importante que as empresas tenham como medir os ganhos alcançados, pois dessa forma, o projeto ganha credibilidade e força para ser ampliado.

\subsection{Considerações finais}

Todas as empresas estudadas mostraram interesse em dar continuidade aos projetos Lean, estendendo para outras famílias ou intensificando a implementação do mesmo. Os entrevistados acreditam que somente com a utilização de Produção Enxuta conseguiram alcançar a maioria dos resultados pretendidos.

Algumas vantagens que os projetos trouxeram para as empresas, apontadas pelos entrevistados:

$>$ Houve uma grande mudança cultural dos funcionários,

Ter uma vantagem estratégica para a empresa, já que os gerentes conseguiram ter mais tempo para planejar estrategicamente,

Houve uma confiabilidade no sistema, o que acabou resultando em uma maior tranqüilidade para realizar as tarefas, e

Foi constatado um maior fator motivacional dos funcionários, já que eles se sentiram valorizados. 
Quanto às desvantagens relacionadas como o projeto pode-se destacar:

Alguns atritos gerados com funcionários relacionados com entendimento dos conceitos,

Uma dificuldade de capacitação e motivação das pessoas para a mudança, e

A difícil tarefa de gerenciamento da Produção Enxuta em paralelo com o sistema de lotes de produção, quando a empresa opta por fazer um projeto piloto.

A presente pesquisa tem fatores limitantes como a falta de um conhecimento aprofundado da realidade de cada empresa e a falta de meios para a comprovação da veracidade das respostas obtidas. Mais uma vez ressalta-se que as entrevistas foram feitas com os gerentes do projeto, que podem ter apresentado uma visão otimista do projeto.

No entanto, apesar desta falha, a contribuição deste trabalho foi criar um panorama sobre o nível de utilização de Produção Enxuta pelas empresas nacionais de máquinas e implementos agrícolas em um determinado período de tempo, mostrando sua aplicação e resultados.

A pesquisa como parte de estudos do IFM (Instituto Fábrica do Milênio) contribuiu também para ampliar o conhecimento dos pesquisadores do setor de máquinas e implementos agrícolas, que até os dias atuais, não contam com muitos trabalhos publicados. O grupo GMMO do Departamento de Engenharia de Produção da Escola de Engenharia de São Carlos (EESC -USP) vêm buscando ampliar os conhecimentos neste setor e apresentar os resultados das pesquisas para a divulgação de conhecimento.

\subsection{Trabalhos futuros}

A pesquisa realizada trouxe um panorama dos benefícios que uma implementação de Produção Enxuta pode trazer para as empresas brasileiras de máquinas e implementos agrícolas.

Porém outros trabalhos podem auxiliar a melhor implementação da Produção Enxuta por parte das empresas, como por exemplo a proposta de uma análise de estratégias de implementação (piloto, programática ou prototipal), relacionando a melhor sequiência de implementação das práticas e resultados cada uma pode 
proporcionar.

Outra proposta de estudo seria fazer um este mesmo tipo de levantamento direcionado para outros setores econômicos brasileiros.

E por fim poderia ser feito um estudo focado em medidas de desempenho, considerando resultados intermediários e finalísticos. Neste caso, a pesquisa de campo poderia ser direcionada aos diretores, sócios e líderes das empresas, podendo ou não comparar os dados obtidos com os dados fornecidos pelo gerente de projeto. 


\section{REFERÊNCIAS}

AAKER, D. A.; KUMAR, V.; DAY, G.S. (2001). Pesquisa de marketing. São Paulo: Atlas.

ANDRADE, M. O. (2002). Representação e analise de cadeia de suprimentos: uma proposta baseada no mapeamento do fluxo de valor. Dissertação (Mestrado)- Escola de Engenharia de São Carlos, Universidade de São Paulo.

ANTUNES JUNIOR, J. A. V. (2001). Manutenção produtiva total: uma análise crítica a partir de sua inserção no sistema toyota de produção. Disponível em: <> Acesso em: 29 nov 2004.

ARAUJO, C. A. C.; RENTES, A. F. (2005) Implementação de sistemas de produção enxuta por meio de eventos kaizen. Banas Qualidade. Ago 2005.

ASSOCIAÇÃO BRASILEIRA DA INDÚSTRIA DE MAQUINAS E EQUIPAMENTOS (2003). Investimentos em alta. Disponível em: < http:// abimaq.org.br/painel_show.asp?id=305>. Acesso em: 23 set. 2003.

\section{ASSOCIAÇÃO NACIONAL DOS FABRICANTES DE VEÍCULOS}

AUTOMOTORES (2004). Brasil: Exportações de máquinas agrícolas automotrizes. Disponível em: <http://www.anfavea.com.br/Tabelas2004/Tratores/TTAB3EXP.doc> Acesso em: 10 abr. 2004.

BANCO NACIONAL DE DESENVOLVIMENTO ECONÔMICO E SOCIAL (1995). Máquinas e implementos agrícolas. Disponível em:

<http://www.bndes.gov.br/conhecimento/setorial/get4_is2.pdf>. Acesso em: $12 \mathrm{abr}$. 2004.

BATTAGLIA, F. (2003). Os primeiros passos rumo à Contabilidade Lean. Disponível em: < http://www.lean.org.br/pg1.htm>. Acesso em 15 mai. 2003.

BLACK, J. T. (1998). O projeto da fábrica com futuro. Porto Alegre: Artes Médicas. 
BOTOME, S. P. (1997). Processos comportamentais básicos em metodologia de pesquisa: da delimitação do problema à coleta de dados. Chronos, Caxias do Sul, v. 30, n.1, p. 43-69, jan/jun.

BOZZONE, V. (2002). Speed to market - lean manufacturing for job shops. New York: Amacom.

BRASSARD, M. (1992). Qualidade: ferramentas para uma melhoria contínua. Rio de Janeiro: Qualitymark.

CARNEIRO, F. L. (2004). Proposição de melhoria para o sistema corporativo de produção da Volkswagen do Brasil e uma aplicação piloto desta proposta. Dissertação (Mestrado) - Escola de Engenharia de São Carlos, Universidade de São Paulo, São Carlos.

CERVO, A. L. ; BERVIAN, P. A. (1996). Metolodogia científica. 4 ed. São Paulo: Makron Books.

CHADE, J. (2002). Potencial agrícola brasileiro assusta EUA. Disponível em: < http://www.amcham.com.br/revista/revista2003-02-18c/materia2003-0218e/pagina2003-12-19a>. Acesso em: 20 set. 2003.

CORRÊA, H. L.; GIANESI, I. G. N. (1993). Just in time, MRP II e OPT: um enfoque estratégico. 2.ed. São Paulo: Atlas.

CROSBY, P. B. (1986). Qualidade é investimento. 2. ed. Rio de Janeiro: Makron books.

DEMING, W. E. (1986). Out of crisis. Cambridge: Massachusetts Institute of Technology.

DEMO, P. (2001). Saber pensar. 2.ed. São Paulo: Cortez: Instituto Paulo Freire.

ESCOLA SUPERIOR DE AGRICULTURA LUIZ DE QUEIROZ (2003). A evolução do PIB do Agronegocio no Brasil de 1994 a 2001. Disponível em: < http://cepea.esalq.usp.br/pib/zip/artigo\%20PIB.pdf>. Acesso em: 08 set. 2003.

FELD, W. M. (2001). Lean manufacturing: tools, techniques, and how to use them. Virginia, USA: APICS. 
FERREIRA, A. B. H. (1975) Novo dicionário da língua portuguesa. Rio de Janeiro: Nova Fronteira. p. 1125.

FERRO, J. R. (2003). A essência da ferramenta "mapeamento do fluxo de valor". Disponível em: <http://www.lean.org.br.> Acesso em: 4 Mar. 2004.

FERRO, J. R. (2004). O que é Lean Thinking. Disponível em: <http://www.lean.org.br.> Acesso em: 10 Mai. 2005.

FUTEMA, F. (2004). Máquinas agrícolas devem puxar exportação recorde de veículos. Disponível em:

<http://www1.folha.uol.com.br/folha/dinheiro/ult91u81459.shtml>. Acesso em: 26 abr. 2004.

GHINATO, P. (2000). Produção \& Competitividade: Aplicações e Inovações. Recife: UFPE

GIL, A. C. (1991). Como elaborar projetos de pesquisas. São Paulo: Atlas.

HAHN, S. (2005). Máquinas agrícolas: exportação deve sustentar crescimento em 2005. O Estado de São Paulo, São Paulo, 12 jan. Disponível em:

<http://www.estadao.com.br/agronegocios/noticias/2005/jan/12/56.htm >. Acesso em: 14 jan. 2005.

HINES, P.; TAYLOR, D. (2000). Going lean. Lean Enterprise Centre

HINES, P.; HOLWEG, M.; RICH, N. (2004). Learning to evolve. A review of contemporary lean thinking. International Journal of Operations \& Production Management. v 24, n. 10, 2004. Disponível em:

$<$ http://miranda.emeraldinsight.com $/ \mathrm{vl}=755484 / \mathrm{cl}=60 / \mathrm{nw}=1 / \mathrm{fm}=\mathrm{docpdf} / \mathrm{rpsv} / \mathrm{cw} / \mathrm{mcb} / 0$ $1443577 / \mathrm{v} 24 \mathrm{n} 10 / \mathrm{s} 2 / \mathrm{p} 994>$. Acesso em 24 jan 2005.

HOPPEN et al. (1996). Um guia para a avaliação de artigos de pesquisa em sistemas de informação. Rev. Eletronica em Adm., v. 2, n.2.

IMAI, M. (1994). Kaizen: a estratégia para o sucesso competitivo. 5 ed. São Paulo: Imam.

IMAI, M. (1996). Gemba-kaizen: estratégias e técnicas do kaizen no piso de fábrica. São Paulo: Imam. 
JURAN, J. M. (1990). Planejando para a qualidade. São Paulo: Pioneira.

LEAN INSTITUTE BRASIL (2005). Apoios estruturados. Disponível em: < http://www.lean.org.br/bases.php?interno=suporte_apoios>. Acesso em: 10 fev 2005. LEAN SUMMIT , 2002, Gramado. Anais... Gramado: Lean Institute Brasil, 2002.

MACDONALD, T; AKEN, E.; RENTES, A. F. (2000). Utilization of simulation model to support value stream analysis and definition of future state scenarios in a hightechnology motion control plant. Research Paper. Departament of Industrial \& Systems Engineering, Virginia Polytechnic Institute and State University \& São Carlos Engineering School, University of São Paulo.

MAESTRELLI et 1. (2002). A manufatura enxuta e sua aplicação aos processos de conformação de metais. Máquinas e Metais, São Paulo, n. 439, p.278-295.

MARTINS, P. G. (1998). Administração da produção. São Paulo: Saraiva.

MASKELL, B.; BAGGALEY, B. (2004). Practical Lean Accounting: a proven system for measuring and managing the lean enterprise. Ney York: Productivity

MEDEIROS, S. F. (2002). Metodologia para implementação de células autônomas ou semi-autônomas focada no desenvolvimento de competências. Dissertação (Mestrado em Engenharia de Produção). Universidade Federal de Santa Catarina, Florianópolis, 2002. Disponível em: < http://teses.eps.ufsc.br/defesa/pdf/6064.pdf>. Acesso em: 27 de dezembro de 2004.

MONDEN, Y. (1998). Toyota Production System. São Paulo: Imam.

MOURA, R. A. (1992). Kanban, a simplicidade do controle de produção. São Paulo: Imam.

NISHIDA, L. T. (2005). Como determinar metas para o tempo de setup. Lean Institute. Disponível em: 〈http://www.lean.org.br/bases.php?\&interno=artigo_18> . Acesso em:26 abr. 2005.

OHNO, T. (1988). Toyota Production System - beyond large-scale production. Portland: Productivity, Inc. 
OSADA, T. (1992) Housekeeping.5S's: seiri, seiton, seiso, seiketsu, shitsuke. São Paulo: Imam.

PINTO, A.K.; XAVIER, J.N. (1998). Manutenção: Função estratégica. Rio de Janeiro: Qualitymark.

PORTER, M. E. (1999). Competição - estratégias competitivas essenciais, tradução de Afonso Celso da Cunha Serra, Rio de Janeiro: Campus.

RENTES, A. F. (2003). Recomendações para o estado futuro. São Carlos. Notas de aula.

RIBEIRO, P. D. (1986). Kanban, resultados de uma implementação bem sucedida. 2. ed. Rio de Janeiro: COP .

ROESCH, S. M. A. (1999). Projetos de estágios e de pesquisa em administração: guia para estágios, trabalhos de conclusão, dissertações e estudos de caso. 2 ed. São Paulo: Atlas.

ROTHER, M.; SHOOK, J. (1998). Learning to see - Value Stream mapping to Add Value and Eliminate Muda. The Lean Enterprise Institute, MA, USA

SHINGO, S. (1996a). Sistemas de produção com estoque zero: o sistema Shingo para estoque zero. Porto Alegre: Artes Médicas.

. (1996b). Quick changeover for operations: The SMED system. New York: Productivity Press.

SILVA, E. L.; MENEZES,E. M. (2000). Metodologia da pesquisa e elaboração de dissertação. $2^{\text {a }}$ ed. Revisada, UFSC, Florianópolis, SC.

SLACK, N. et al. (1999). Administração da Produção. 3. ed. São Paulo: Atlas.

SPEAR, S.; BOWEN, H.K. (1999) Decoding the DNA of the Toyota Production System. Harvard Business Review, Boston, v. 77, n.5, p. 97- 106

STAKE, R. (1994). Handbook of Qualitative Research. Thousand Oaks: Sage. 
TAKAHASHI, Y.; OSADA, T. (1993). TPM/MPT manutenção produtiva total. São Paulo: Imam.

TRIVIÑOS, A. N. S. (1987). Introdução à pesquisa em ciências sociais: a pesquisa qualitativa em educação. São Paulo, Atlas.

UNITED STATES DEVELOPMENT AGRICULTURAL (2003). U. S. Agricultural trade: global agricultural trade. Disponível em: < http://www.ers.usda.gov/BRIEFING/AgTrade/commoditytrade.htm>. Acesso em: 22 set. 2003.

VEGRO, C. L. R. (2004). Máquinas Agrícolas: Expectativa De Melhor Performance. Disponivel em: <http://www.iea.sp.gov.br/out/verTexto.php?codTexto=1233> . Acesso em: 26 abr. 2004.

WOMACK, J.; JONES, D.; ROOS, D. (1990). The Machine that Changed the World.The Story of Lean Production. New York: Rawson Associates.

WOMACK, J. P.; JONES, D. T. (1998). A mentalidade enxuta nas empresas: elimine o desperdício e crie riqueza. Rio de Janeiro: Campus.

YIN, R. K. (1981). The case study crisis: some answers. Administrative Science Quartely, Cornell University, v. 26. 


\section{APÊNDICE A - RoteIro de ENTREVISTA DA EMPRESA A}

\section{Roteiro de entrevista}

\section{Data: $07 / 04 \quad / 2005$}

Nome da empresa: Empresa A

Ramo de atividade: Máquinas Agrícolas

Produtos: Distribuidores de fertilizantes e corretivos, Roçadeiras e Desintegra dores de cultura.

Faturamento: Aproximadamente R $\$ 4$ milhões anuais

Principais clientes: Empresa E e outras

Principais concorrentes: Empresa G e outras

Número de funcionários: 120 funcionários

Entrevistado: Agenor Cancelier

Cargo: Superintendente Geral/ Gerente do Projeto Lean

\section{Histórico}

1.1) Quando e por que a empresa começou a utilizar a Produção Enxuta?

A implementação começou em setembro de 2004 por dois motivos: porque a empresa acreditava que este sistema era mais produtivo e porque a empresa $\mathrm{E}$, principal parceira, já operava neste sistema e ela queria ampliar para seus fornecedores.

1.2) Qual sua participação no mercado consumidor naquele momento? 
O incremento de vendas 2004/2003 foi da ordem de 32\% já descontada a inflação do período. Eu não conseguiria segregar $o$ que foi aumento de eficiência produtiva do que foi expansão de demanda de mercado.

1.3) Os fatores motivadores para a mudança foram internos ou externos? Quais foram? Explique.

Foram externos. Por causa da parceira.

1.4) Qual(is) foi(ram) o(s) principal(is) agente(s) de mudança?

O presidente da empresa E queria implementar nos seus fornecedores e o Agenor foi o principal agente de mudança dentro da empresa.

1.5) Houve ajuda de terceiros, como consultoria?

( X ) Sim. Como a empresa entrou em contato? Através da empresa E. Qual a razão da escolha? Porque o projeto já era feito na empresa E.

( ) Não. Como se deu a mudança internamente? Qual(is) o(s) método(s) utilizado(s)?

\section{Desenvolvimento e Implementação}

2.1) Qual a estratégia de implementação adotada?

( X ) Implementação Piloto

( ) Implementação Programática

( ) Implementação Prototipal

Família de Máquinas de Distribuidora de fertilizantes e corretivos.

2.2) Qual(is) foi(ram) a(s) principal(is) medida(s) tomada(s) quando começou a implementação da Produção Enxuta?

Formação de uma equipe.

Treinamento com todos os funcionários

Implementação

2.3) Quais e quantos funcionários foram envolvidos na implementação?

O superintendente geral (gerente do projeto) e os líderes de cada área de manufatura, perfazendo um total de 6 pessoas.

2.4) Quais foram os principais problemas encontrados no projeto e na implementação?

O projeto começou quando os produtos da empresa E estavam em alta demanda. Mas a partir de outubro e até março, período de entre safra, o projeto precisou sofrer uma interrupção temporária. A empresa procurou outros parceiros para tentar estabilizar sua produção e evitar assim a demissão de muitos funcionários.

2.5) Qual o investimento estimado na implementação da Produção Enxuta? 
A empresa $\mathrm{E}$ paga a consultoria e fornece os materiais necessários e a empresa A fornece sua mão-de-obra.

2.6) O sistema de custeio dos produtos e do gerenciamento dos custos da empresa foi afetado pelo projeto de Produção Enxuta?

Não é aplicado, porque é a empresa E que faz o custeio dos produtos.

2.7) Após a implementação da Produção Enxuta, a empresa precisou modificar sua medida de desempenho de produção de máquinas/ operador?

A empresa não possui esta medida e o projeto ainda não abordou.

2.8) A empresa utilizava algum sistema de medição de desempenho para setup? Após a implementação da Produção Enxuta este sistema foi alterado?

A redução de setup ainda não foi trabalhada. E anteriormente não existia esta medida.

2.9) Qual era o takt time da operação antes da implementação da Produção Enxuta e qual é o atual?

Antes do projeto era de 2 horas.

Depois passou a ser 52 minutos. 
(A partir deste ponto o roteiro de entrevista irá apresentar algumas perguntas referentes às práticas da Produção Enxuta, com alternativas, por favor assinale aquela que mais se adequar a sua empresa)

\section{3) Práticas}

3.1)Quanto à utilização dos $5 \mathrm{~S}$, pode-se afirmar que trouxe impactos significativos para a empresa quanto a melhoria no ambiente de trabalho.

3.2) O 5S serviu de elemento inicial para a implementação base para a disseminação dos conceitos da Produção Enxuta na empresa.

3.3) A padronização do trabalho contribuiu para melhor utilização dos recursos da empresa.

3.4) A padronização do trabalho foi implementada extensivamente na empresa.

3.5) A utilização do Layout celular trouxe grandes mudanças no chão de fábrica quanto à disposição das máquinas e equipamentos.

3.6) O Layout celular foi utilizado extensivamente na empresa.

3.7) A utilização do Kanban trouxe agilidade nos processos produtivos quanto à necessidade de material ou de informações.

3.8) O Kanban foi utilizado extensivamente na empresa.

3.9) A utilização do Heijunka box ou o nivelamento de produção trouxe maior flexibilização e precisão na produção através de ajustes e reprogramação dos operadores.

3.10) Com a utilização do Mapa do Fluxo de Valor conseguiu-se visualizar e entender melhor todos os processos produtivos da empresa.

3.11) Com a utilização do Mapa do Fluxo de Valor, a empresa conseguiu tomar as melhores decisões e seguir um plano de ações estruturadas.

3.12) A utilização da Manutenção Produtiva Total trouxe diminuição nas paradas imprevistas de máquinas, facilitando atingir as metas de produção.

3.13) Com a utilização da Administração da Qualidade Total, os funcionários criaram um senso de responsabilidade e autoridade quanto à produção.

3.14) A Administração da Qualidade Total trouxe para a empresa redução nos custos da qualidade.

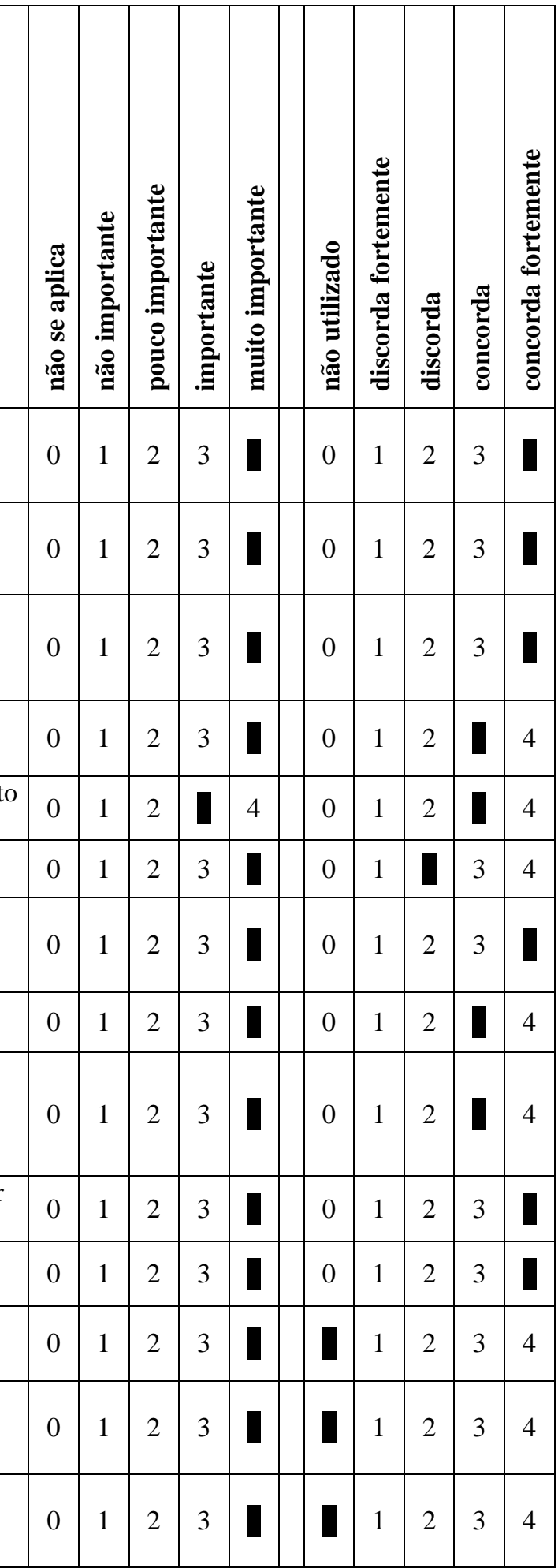




\section{Os Resultados Obtidos}

(Na tabela abaixo, assinale a alternativa que melhor exprima a realidade da empresa)

\begin{tabular}{|c|c|c|c|c|c|}
\hline $\begin{array}{l}\text { Quanto aos resultados obtidos devido ao uso da Produção Enxuta, a } \\
\text { empresa: }\end{array}$ & 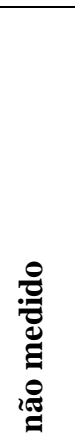 & 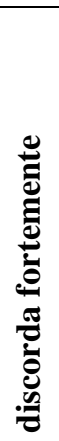 & 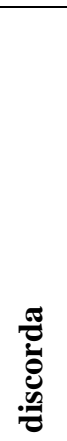 & 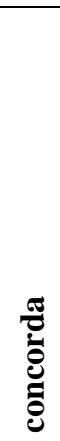 & 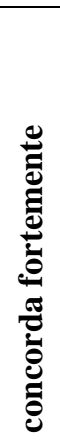 \\
\hline 4.1) Conseguiu melhorar sua produtividade em relação à produção/recursos/tempo. & 0 & 1 & 2 & 3 & \\
\hline $\begin{array}{l}\text { 4.2) Conseguiu melhorar o atendimento no prazo do pedido de seus clientes, ou seja, melhorou a } \\
\text { pontualidade de entrega. }\end{array}$ & 0 & 1 & 2 & 3 & \\
\hline 4.3) Conseguiu reduzir o lead time de fabricação. & 0 & 1 & 2 & 3 & \\
\hline 4.4) Conseguiu reduzir os custos de fabricação. & 0 & 1 & 2 & & 4 \\
\hline 4.5) Aumentou o faturamento. & 0 & 1 & 2 & & 4 \\
\hline 4.6) Aumentou a lucratividade. & 0 & 1 & 2 & 3 & \\
\hline 4.7) Diminuiu os estoques de matéria-prima. & 0 & 1 & 2 & 3 & \\
\hline 4.8) Diminuiu os estoques de material em processo. & 0 & 1 & 2 & 3 & \\
\hline 4.9) Diminuiu os estoques de produto acabado. & 0 & 1 & 2 & 3 & 4 \\
\hline $\begin{array}{l}\text { 4.10) Conseguiu reduzir a área de produção, por causa de rearranjos no layout do chão de } \\
\text { fábrica. }\end{array}$ & 0 & 1 & 2 & ] & 4 \\
\hline 4.11) Conseguiu reduzir a movimentação de material e pessoas. & 0 & 1 & 2 & 3 & \\
\hline 4.12) Conseguiu aumentar sua participação no mercado consumidor. & 0 & 1 & 2 & 3 & \\
\hline 4.13) Percebeu mudanças culturais em seus funcionários e no ambiente de trabalho. & 0 & 1 & 2 & 3 & \\
\hline 4.14) Influenciou significativamente a política de vendas/marketing. & T & 1 & 2 & 3 & 4 \\
\hline 4.15) Mudou a política de desenvolvimento do produto. & 1 & 1 & 2 & 3 & 4 \\
\hline 4.16) Aumentou a qualidade de seus produtos. & 0 & 1 & 2 & T & 4 \\
\hline 4.17) Aumentou o mix de produtos. & 0 & 1 & 1 & 3 & 4 \\
\hline 4.18) Conseguiu influenciar seus fornecedores quanto à forma de entrega de material. & 0 & 1 & 2 & 3 & \\
\hline 4.19) Aumentou o número de fornecedores. & 0 & 1 & & 3 & 4 \\
\hline 4.20) Diminuiu o número de fornecedores. & 0 & 1 & 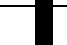 & 3 & 4 \\
\hline 4.21) Alterou seu fluxo de informações. & 0 & 1 & 2 & 3 & \\
\hline
\end{tabular}




\section{Comentários finais.}

\section{1) A empresa continua utilizando a Produção Enxuta?}

Sim. A empresa tem planos para intensificar a implementação.

5.2) A empresa atribui os resultados positivos obtidos somente à implementação da Produção Enxuta? Comente.

Sim. Porque a empresa, antes do projeto, não era lucrativa e hoje ela conseguiu obter lucros.

5.3) Quais outras vantagens encontradas na Produção Enxuta ainda não abordadas neste roteiro de entrevista?

Não citado.

5.4) Quais outras desvantagens encontradas na Produção Enxuta ainda não abordadas neste roteiro de entrevista?

Não citado.

5.5) Faça um comentário sobre um aspecto relacionado a esse assunto e que, possivelmente, não foi abordado (Se sentir necessidade).

As empresas devem implementar a Produção Enxuta como filosofia de gestão, porque acredito que seja o melhor caminho para elas.

Obrigada pela sua colaboração! 


\section{APÊNDICE B- ROTEIRO DE ENTREVISTA DA EMPRESA B}

\section{Roteiro de entrevista}

\section{Data: $17 / 03 \quad / 2005$}

Nome da empresa: Empresa B

Ramo de atividade: Máquinas de Pecuária e de Corte

Produtos: Misturadores e Colhedeiras de Forragem

Faturamento: Em 2004 foi de aproximadamente R\$ 10 milhões.

Principais clientes: Grandes produtores de leite e confinamento de gado. A empresa tem parceria com algumas revendas, mas a maioria das vendas é feita diretamente com o setor comercial. Exportam através de venda direta, principalmente para a América do Sul, Central e do Norte.

Principais concorrentes: Empresa G e outras

Número de funcionários: aproximadamente 80 funcionários

Entrevistado: Luiz Claudio Santac

Cargo: Gerente de Produção/ Gerente do Projeto Lean

\section{Histórico}

1.1) Quando e por que a empresa começou a utilizar a Produção Enxuta?

A empresa começou a implementar o projeto Lean, em outubro de 2004, porque a empresa apresentava uma grande quantidade de desperdícios ao longo do processo produtivo. Algumas pessoas da empresa visitaram empresas, que utilizam a Produção Enxuta e gostaram dos resultados obtidos por elas. 
1.2) Qual sua participação no mercado consumidor naquele momento?

A participação em misturadores era de $70 \%$ e colhedoras tem uma pequena fatia do mercado.

1.3) Os fatores motivadores para a mudança foram internos ou externos? Quais foram? Explique.

Os fatores foram internos, justamente pela quantidade de desperdício no processo produtivo. Não houve um fator externo.

1.4) Qual(is) foi(ram) o(s) principal(is) agente(s) de mudança?

O presidente da empresa foi quem motivou a implementação do projeto. O gerente de produção foi nomeado gerente do projeto Lean.

1.5) Houve ajuda de terceiros, como consultoria?

( X ) Sim. Como a empresa entrou em contato? O presidente da empresa foi em palestras sobre o tema e entrou em contato diretamente com o consultor Qual a razão da escolha? Indicação da empresa D.

( ) Não. Como se deu a mudança internamente? Qual(is) o(s) método(s) utilizado(s)?

\section{Desenvolvimento e Implementação}

2.1) Qual a estratégia de implementação adotada?

( x ) Implementação Piloto

( ) Implementação Programática

( ) Implementação Prototipal

A máquina escolhida foi uma colhedeira de forragem. A razão da escolha se deu porque ela é uma máquina simples e estava em baixa produção, portanto tendo tempo de trabalhar no processo produtivo da mesma.

2.2) Qual(is) foi(ram) a(s) principal(is) medida(s) tomada(s) quando começou a implementação da Produção Enxuta?

Formação do grupo.

Treinamento para todos os níveis da empresa.

Divisão do grupo em 3 equipes, que trabalham diretamente com a consultoria. Cada grupo possui um líder, que é geralmente um gerente. Ele escolhe aleatoriamente uma pessoa de cada setor, para opinar em outros setores.

Implementação

2.3) Quais e quantos funcionários foram envolvidos na implementação?

Os 3 grupos são formados por 6 pessoas: 1 gerente e um funcionário de cada setor.

2.4) Quais foram os principais problemas encontrados no projeto e na implementação? 
O maior problema encontrado foi a resistência do pessoal de chão de fábrica em aceitar a mudança.

A empresa também possui uma grande variedade de produtos e acredito que será difícil gerenciar com o sistema Lean.

2.5) Qual o investimento estimado na implementação da Produção Enxuta?

O maior investimento foi feito na consultoria, e o valor não foi passado. Para fazer os pallets, cartões, etc. a empresa utilizou sobras de material.

2.6) O sistema de custeio dos produtos e do gerenciamento dos custos da empresa foi afetado pelo projeto de Produção Enxuta?

A empresa não possui sistema de custeio A área comercial faz uma pesquisa de mercado, e de acordo com a concorrência é feito o valor de vendas. Não foi trabalhado no projeto este gerenciamento, mas a empresa está buscando formatar este sistema.

2.7) Após a implementação da Produção Enxuta, a empresa precisou modificar sua medida de desempenho de produção de máquinas/ operador?

A empresa não possui esta medida. O que ocorreu na implementação piloto foi um aumento de produtividade, pois antes eram necessárias 6 pessoas para se produzir uma máquina. Hoje são necessárias apenas 4.

2.8) A empresa utilizava algum sistema de medição de desempenho para setup? Após a implementação da Produção Enxuta este sistema foi alterado?

A empresa não possui esta medição e o projeto ainda não implementou.

2.9) Qual era o takt time da operação antes da implementação da Produção Enxuta e qual é o atual?

Antes não tinha essa medida, fabricava sob pedido. Hoje a empresa faz 1 máquina por dia. 
(A partir deste ponto o roteiro de entrevista irá apresentar algumas perguntas referentes às práticas da Produção Enxuta, com alternativas, por favor assinale aquela que mais se adequar a sua empresa)

\section{3) Práticas}

3.1)Quanto a utilização dos 5S, pode-se afirmar que trouxe impactos significativos para a empresa quanto a melhoria no ambiente de trabalho.

3.2) O 5S serviu de elemento inicial para a implementação base para a disseminação dos conceitos da Produção Enxuta na empresa.

3.3) A padronização do trabalho contribuiu para melhor utilização dos recursos da empresa.

3.4) A padronização do trabalho foi implementada extensivamente na empresa.

3.5) A utilização do Layout celular trouxe grandes mudanças no chão de fábrica quanto a disposição das máquinas e equipamentos.

3.6) O Layout celular foi utilizado extensivamente na empresa.

3.7) A utilização do Kanban trouxe agilidade nos processos produtivos quanto à necessidade de material ou de informações.

3.8) O Kanban foi utilizado extensivamente na empresa.

3.9) A utilização do Heijunka box ou o nivelamento de produção trouxe maior flexibilização e precisão na produção através de ajustes e reprogramação dos operadores.

3.10) Com a utilização do Mapa do Fluxo de Valor conseguiu-se visualizar e entender melhor todos os processos produtivos da empresa.

3.11) Com a utilização do Mapa do Fluxo de Valor, a empresa conseguiu tomar as melhores decisões e seguir um plano de ações estruturadas.

3.12) A utilização da Manutenção Produtiva Total trouxe diminuição nas paradas imprevistas de máquinas, facilitando atingir as metas de produção.

3.13) Com a utilização da Administração da Qualidade Total, os funcionários criaram um senso de responsabilidade e autoridade quanto à produção.

3.14) A Administração da Qualidade Total trouxe para a empresa redução nos custos da qualidade.

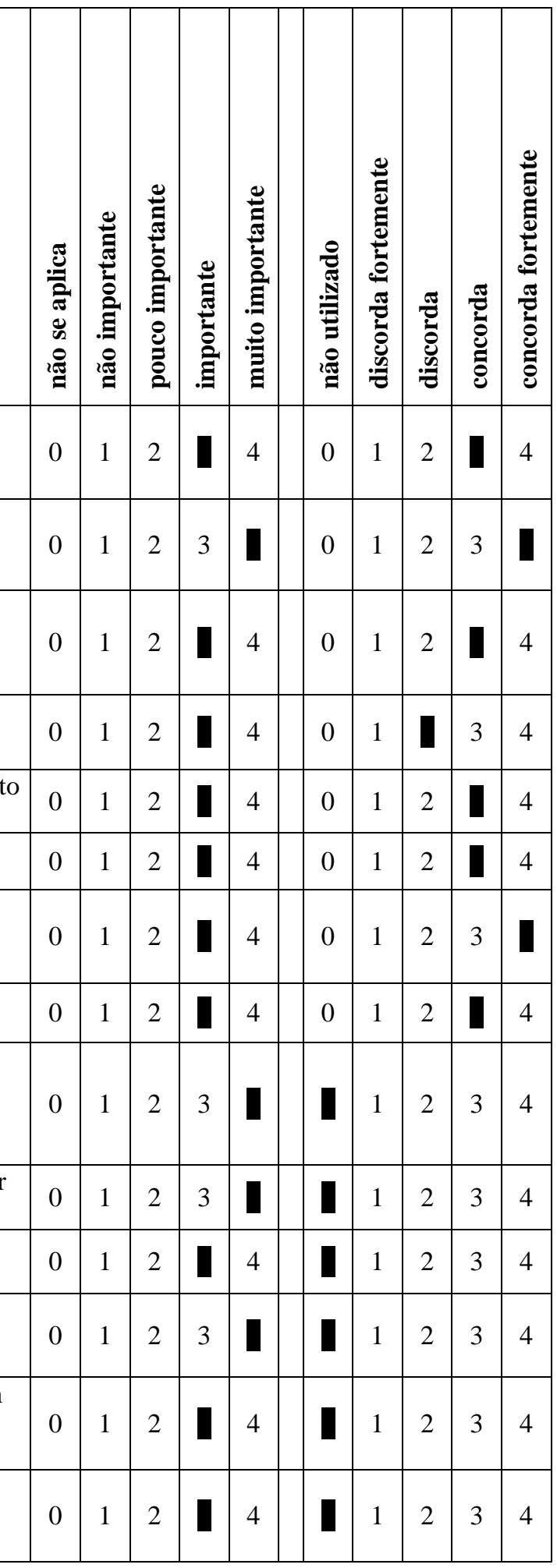




\section{Os Resultados Obtidos}

(Na tabela abaixo, assinale a alternativa que melhor exprima a realidade da empresa)

\begin{tabular}{|c|c|c|c|c|c|}
\hline $\begin{array}{l}\text { Quanto aos resultados obtidos devido ao uso da Produção Enxuta, a } \\
\text { empresa: }\end{array}$ & 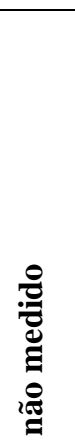 & 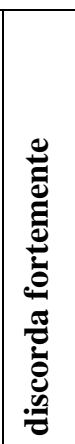 & 苞 & 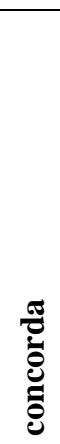 & 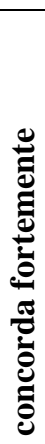 \\
\hline 4.1) Conseguiu melhorar sua produtividade em relação à produção/recursos/tempo. & 0 & 1 & 2 & 0 & 4 \\
\hline $\begin{array}{l}\text { 4.2) Conseguiu melhorar o atendimento no prazo do pedido de seus clientes, ou seja, melhorou a } \\
\text { pontualidade de entrega. }\end{array}$ & 0 & 1 & 2 & 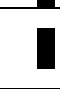 & 4 \\
\hline 4.3) Conseguiu reduzir o lead time de fabricação. & 0 & 1 & 2 & 1 & 4 \\
\hline 4.4) Conseguiu reduzir os custos de fabricação. & & 1 & 2 & 3 & 4 \\
\hline 4.5) Aumentou o faturamento. & & 1 & 2 & 3 & 4 \\
\hline 4.6) Aumentou a lucratividade. & 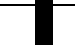 & 1 & 2 & 3 & 4 \\
\hline 4.7) Diminuiu os estoques de matéria-prima. & 0 & 1 & 2 & & 4 \\
\hline 4.8) Diminuiu os estoques de material em processo. & 0 & 1 & 2 & & 4 \\
\hline 4.9) Diminuiu os estoques de produto acabado. & 0 & 1 & 2 & & 4 \\
\hline $\begin{array}{l}\text { 4.10) Conseguiu reduzir a área de produção, por causa de rearranjos no layout do chão de } \\
\text { fábrica. }\end{array}$ & 0 & 1 & 2 & 3 & [ \\
\hline 4.11) Conseguiu reduzir a movimentação de material e pessoas. & 0 & 1 & 2 & 1 & 4 \\
\hline 4.12) Conseguiu aumentar sua participação no mercado consumidor. & & 1 & 2 & 3 & 4 \\
\hline 4.13) Percebeu mudanças culturais em seus funcionários e no ambiente de trabalho. & 0 & 1 & 2 & T & 4 \\
\hline 4.14) Influenciou significativamente a política de vendas/marketing. & & 1 & 2 & 3 & 4 \\
\hline 4.15) Mudou a política de desenvolvimento do produto. & 1 & 1 & 2 & 3 & 4 \\
\hline 4.16) Aumentou a qualidade de seus produtos. & 0 & 1 & 2 & T & 4 \\
\hline 4.17) Aumentou o mix de produtos. & T & 1 & 2 & 3 & 4 \\
\hline 4.18) Conseguiu influenciar seus fornecedores quanto à forma de entrega de material. & 1 & 1 & 2 & 3 & 4 \\
\hline 4.19) Aumentou o número de fornecedores. & 0 & 1 & & 3 & 4 \\
\hline 4.20) Diminuiu o número de fornecedores. & 0 & 1 & 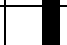 & 3 & 4 \\
\hline 4.21) Alterou seu fluxo de informações. & 0 & 1 & 2 & & 4 \\
\hline
\end{tabular}




\section{Comentários finais.}

\section{1) A empresa continua utilizando a Produção Enxuta?}

Sim. A empresa tem planos de disseminar os conceitos para outras linhas. Porém ainda não existe um plano de implementação formalizado.

5.2) A empresa atribui os resultados positivos obtidos somente à implementação da Produção Enxuta? Comente.

Afirmo que se não fosse o Lean, a empresa não teria obtidos estes resultados.

5.3) Quais outras vantagens encontradas na Produção Enxuta ainda não abordadas neste roteiro de entrevista?

Não me lembrou. O que houve foi uma grande mudança cultural. Antes a empresa fabricava sem as vendas estarem confirmadas!

5.4) Quais outras desvantagens encontradas na Produção Enxuta ainda não abordadas neste roteiro de entrevista?

Os atritos gerados com os funcionários em relação ao entendimento dos conceitos e a forma como seria colocado em prática.

5.5) Faça um comentário sobre um aspecto relacionado a esse assunto e que, possivelmente, não foi abordado (Se sentir necessidade).

Toda a empresa que aplicou está em um nível melhor no mercado consumidor. O Lean é um facilitador. As pessoas têm tempo para pensar estrategicamente.

Obrigada pela sua colaboração! 


\section{APÊNDICE C - RoteIro de ENTREVISTA DA EMPRESA C}

\section{Roteiro de entrevista}

\section{Data: $14 / 04 \quad / 2005$}

Nome da empresa: Empresa C

Ramo de atividade: Máquinas e Implementos Agrícolas

Produtos: Colhedeiras, forrageiras, trituradores, debulhadores

Faturamento: Não fornecido

Principais clientes: Empresa E

Principais concorrentes: Empresa A e outras

Número de funcionários: aproximadamente 98 funcionários

Entrevistado: José Gonçalves Nunes Junior e Clodoaldo Antônio Ventreschi

Cargo: Supervisor de segurança do trabalho e chefe do almoxarifado, respectivamente

\section{Histórico}

1.1) Quando e por que a empresa começou a utilizar a Produção Enxuta?

A empresa possui uma parceria com a empresa E, que começou em 1999, onde a última fornece o material e a primeira produz e entrega. Nesta parceria a empresa $\mathrm{C}$ produzia sob ordem de produção

O projeto começou em julho de 2004, porque o mercado consumidor estava exigente e a empresa precisava acompanhar as mudanças e para se adaptar ao sistema utilizado na empresa E.

1.2) Qual sua participação no mercado consumidor naquele momento? 
Os dados de mercado são da empresa E.

1.3) Os fatores motivadores para a mudança foram internos ou externos? Quais foram? Explique.

O fator externo foi a exigência a empresa $E$.

$\mathrm{O}$ fator interno foi a dificuldade de obter informações precisas na empresa.

1.4) Qual(is) foi(ram) o(s) principal(is) agente(s) de mudança?

Os dois entrevistados.

1.5) Houve ajuda de terceiros, como consultoria?

( x ) Sim. Como a empresa entrou em contato? Através da empresa E. Qual a razão da escolha? A empresa E já trabalhava com ela.

( ) Não. Como se deu a mudança internamente? Qual(is) o(s) método(s) utilizado(s)?

\section{Desenvolvimento e Implementação}

2.1) Qual a estratégia de implementação adotada?

( ) Implementação Piloto

( x ) Implementação Programática

( ) Implementação Prototipal

Famílias de produtos: Plataformas, Eixos Sextavados, kits e Colheitadeiras

2.2) Qual(is) foi(ram) a(s) principal(is) medida(s) tomada(s) quando começou a implementação da Produção Enxuta?

Formação de Equipe

Treinamento com palestras e reuniões, somente para a equipe e diretoria Implementação:

- Levantamento do Layout,

- Aplicação do 5S

- Programação de Kanbans., que estava sendo implementada.

2.3) Quais e quantos funcionários foram envolvidos na implementação?

$\mathrm{Na}$ equipe do projeto foram alocadas 3 pessoas: 1 gerente do projeto, 1 funcionário do setor de usinagem e 1 da montagem, juntamente com a consultoria e os dois entrevistados.

2.4) Quais foram os principais problemas encontrados no projeto e na implementação?

A empresa tinha falta de informações seguras, e com o projeto esses dados precisaram ser coletados.

Outra dificuldade foi a resistência dos funcionários em trabalharem no novo sistema.

2.5) Qual o investimento estimado na implementação da Produção Enxuta? 
A empresa não teve gastos significativos e a empresa E está pagando os gastos com a consultoria.

2.6) O sistema de custeio dos produtos e do gerenciamento dos custos da empresa foi afetado pelo projeto de Produção Enxuta?

O sistema de custeio do produto é feito pela empresa E. A empresa $\mathrm{C}$ ganha através das horas despendidas em cada peça.

2.7) Após a implementação da Produção Enxuta, a empresa precisou modificar sua medida de desempenho de produção de máquinas/ operador?

A empresa não possui essa medição.

2.8) A empresa utilizava algum sistema de medição de desempenho para setup? Após a implementação da Produção Enxuta este sistema foi alterado?

A empresa não possui essa medição.

2.9) Qual era o takt time da operação antes da implementação da Produção Enxuta e qual é o atual?

O tempo takt ainda não foi medido. 
(A partir deste ponto o roteiro de entrevista irá apresentar algumas perguntas referentes às práticas da Produção Enxuta, com alternativas, por favor assinale aquela que mais se adequar a sua empresa)

\section{3) Práticas}

3.1)Quanto a utilização dos 5S, pode-se afirmar que trouxe impactos significativos para a empresa quanto a melhoria no ambiente de trabalho.

3.2) O 5S serviu de elemento inicial para a implementação base para a disseminação dos conceitos da Produção Enxuta na empresa.

3.3) A padronização do trabalho contribuiu para melhor utilização dos recursos da empresa.

3.4) A padronização do trabalho foi implementada extensivamente na empresa.

3.5) A utilização do Layout celular trouxe grandes mudanças no chão de fábrica quanto a disposição das máquinas e equipamentos.

3.6) O Layout celular foi utilizado extensivamente na empresa.

3.7) A utilização do Kanban trouxe agilidade nos processos produtivos quanto à necessidade de material ou de informações.

3.8) O Kanban foi utilizado extensivamente na empresa.

3.9) A utilização do Heijunka box ou o nivelamento de produção trouxe maior flexibilização e precisão na produção através de ajustes e reprogramação dos operadores.

3.10) Com a utilização do Mapa do Fluxo de Valor conseguiu-se visualizar e entender melhor todos os processos produtivos da empresa.

3.11) Com a utilização do Mapa do Fluxo de Valor, a empresa conseguiu tomar as melhores decisões e seguir um plano de ações estruturadas.

3.12) A utilização da Manutenção Produtiva Total trouxe diminuição nas paradas imprevistas de máquinas, facilitando atingir as metas de produção.

3.13) Com a utilização da Administração da Qualidade Total, os funcionários criaram um senso de responsabilidade e autoridade quanto à produção.

3.14) A Administração da Qualidade Total trouxe para a empresa redução nos custos da qualidade.

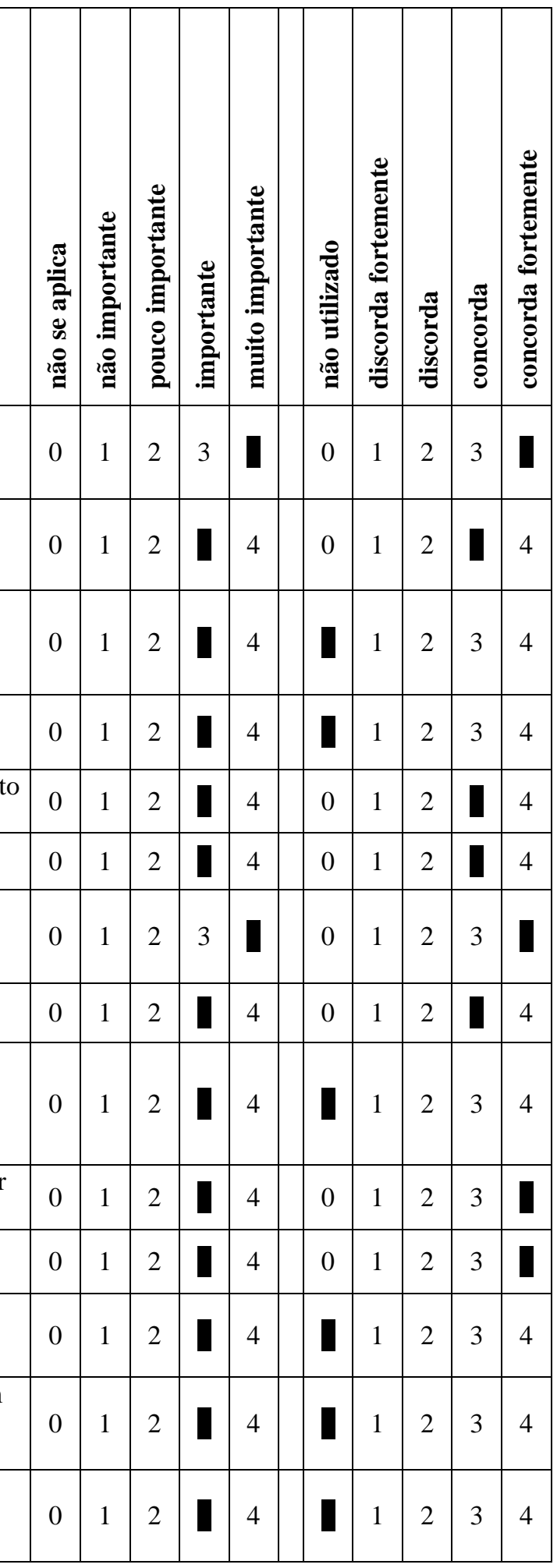




\section{Os Resultados Obtidos}

(Na tabela abaixo, assinale a alternativa que melhor exprima a realidade da empresa)

\begin{tabular}{|c|c|c|c|c|c|}
\hline $\begin{array}{l}\text { Quanto aos resultados obtidos devido ao uso da Produção Enxuta, a } \\
\text { empresa: }\end{array}$ & 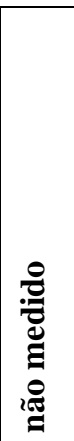 & 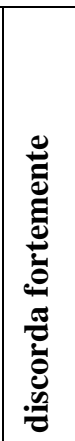 & 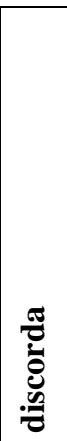 & 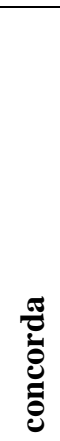 & 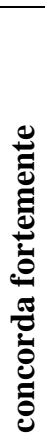 \\
\hline 4.1) Conseguiu melhorar sua produtividade em relação à produção/recursos/tempo. & 0 & 1 & 2 & 0 & 4 \\
\hline $\begin{array}{l}\text { 4.2) Conseguiu melhorar o atendimento no prazo do pedido de seus clientes, ou seja, melhorou a } \\
\text { pontualidade de entrega. }\end{array}$ & 0 & 1 & 2 & 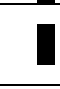 & 4 \\
\hline 4.3) Conseguiu reduzir o lead time de fabricação. & & 1 & 2 & 3 & 4 \\
\hline 4.4) Conseguiu reduzir os custos de fabricação. & & 1 & 2 & 3 & 4 \\
\hline 4.5) Aumentou o faturamento. & & 1 & 2 & 3 & 4 \\
\hline 4.6) Aumentou a lucratividade. & & 1 & 2 & 3 & 4 \\
\hline 4.7) Diminuiu os estoques de matéria-prima. & 0 & 1 & 2 & 1 & 4 \\
\hline 4.8) Diminuiu os estoques de material em processo. & & 1 & 2 & 3 & 4 \\
\hline 4.9) Diminuiu os estoques de produto acabado. & & 1 & 2 & 3 & 4 \\
\hline $\begin{array}{l}\text { 4.10) Conseguiu reduzir a área de produção, por causa de rearranjos no layout do chão de } \\
\text { fábrica. }\end{array}$ & 0 & 1 & 2 & 0 & 4 \\
\hline 4.11) Conseguiu reduzir a movimentação de material e pessoas. & & 1 & 2 & 3 & 4 \\
\hline 4.12) Conseguiu aumentar sua participação no mercado consumidor. & & 1 & 2 & 3 & 4 \\
\hline 4.13) Percebeu mudanças culturais em seus funcionários e no ambiente de trabalho. & 0 & 1 & 2 & 1 & 4 \\
\hline 4.14) Influenciou significativamente a política de vendas/marketing. & & 1 & 2 & 3 & 4 \\
\hline 4.15) Mudou a política de desenvolvimento do produto. & & 1 & 2 & 3 & 4 \\
\hline 4.16) Aumentou a qualidade de seus produtos. & 0 & 1 & 2 & 1 & 4 \\
\hline 4.17) Aumentou o mix de produtos. & & 1 & 2 & 3 & 4 \\
\hline 4.18) Conseguiu influenciar seus fornecedores quanto à forma de entrega de material. & & 1 & 2 & 3 & 4 \\
\hline 4.19) Aumentou o número de fornecedores. & & 1 & 2 & 3 & 4 \\
\hline 4.20) Diminuiu o número de fornecedores. & & 1 & 2 & 3 & 4 \\
\hline 4.21) Alterou seu fluxo de informações. & 0 & 1 & 2 & & 4 \\
\hline
\end{tabular}




\section{Comentários finais.}

\section{1) A empresa continua utilizando a Produção Enxuta?}

Sim. A empresa tem planos para dar continuidade no projeto.

5.2) A empresa atribui os resultados positivos obtidos somente à implementação da Produção Enxuta? Comente.

Sim.

5.3) Quais outras vantagens encontradas na Produção Enxuta ainda não abordadas neste roteiro de entrevista?

Não

5.4) Quais outras desvantagens encontradas na Produção Enxuta ainda não abordadas neste roteiro de entrevista?

Não

5.5) Faça um comentário sobre um aspecto relacionado a esse assunto e que, possivelmente, não foi abordado (Se sentir necessidade).

O projeto ajudou a dar uma melhor visão de como as máquinas são fabricadas e como as informações são necessárias. Melhorou também a troca de informações entre as empresas.

Obrigada pela sua colaboração! 


\section{APÊNDICE D - ROTEIRO DE ENTREVISTA DA EMPRESA D}

\section{Roteiro de entrevista}

Data: $04 / 03 / 2005$

Nome da empresa: Empresa D

Ramo de atividade: Máquinas e Implementos Agrícolas

Produtos: As principais linhas são:

- Pulverizadores: costal manual (para uso agrícola e residencial), motorizados (para uso de detetização), tracionados por tratores, aclopados e autopropelido (pulverizadores com motores);

- Colhedeiras (para cultura de café e azeitona);

- Adubadeiras automotrizes.

A empresa também conta com as linhas de limpeza industrial e doméstica; com a uma unidade de carrinho elétrico, utilizados em jogos de futebol; e uma linha de saneamento, para tratamento de água.

A principal família de produtos é a dos pulverizadores agrícolas.

Faturamento: R\$900milhões anuais

Principais clientes: A empresa vende seus produtos através de revendas, sendo que seus maiores clientes são duas cooperativas: a Coopercitrus, em Bebedouro-SP e a Coamo, em Campo Mourão. A empresa também exporta seus produtos para mais de 80 países, correspondendo essas exportações em cerca de $20 \%$ do faturamento.

A empresa possui uma filial na Argentina e uma join-venture nos EUA.

Principais concorrentes: Empresa F, I e outra

Número de funcionários: aproximadamente 2000 funcionários

Entrevistado: José Luiz Yanaguizawa

Cargo: Gerente de Planejamento e Controle da Produção e Logística/ Gerente do Projeto 


\section{Histórico}

1.1) Quando e por que a empresa começou a utilizar a Produção Enxuta?

Em 1996, a empresa começou estudar uma mudança sobre o aspecto tecnológico e competitivo no ramo da agricultura. O IMAM (Instituto de Movimentação e Armazenagem de Materiais) começou a explicar sobre Logística, Supply Chain, e qual a finalidade dessas novas técnicas de administração. A empresa percebeu que as empresas automobilísticas tinham um sistema de produção diferente e avançado, e juntamente com o IMAM iniciaram os estudos sobre este sistema. Até aquele presente momento, a empresa trabalhava com produção em grandes lotes.

Em 1999, o Lean Institute montou um workshop na Mercedes-Bens e uma equipe da empresa participou. Foi nesta ocasião que esta equipe conheceu o sistema Lean e começaram a entender como coloca-lo na fábrica, para serem mais competitivos. Após isso, esta equipe fez alguns cursos do Lean Institute e introduziram em uma linha de pulverizadores (Condor).

O projeto começou em 2000, justamente quando houve um boom no agronegocio naquele ano. E graças à introdução do sistema Lean, a empresa conseguiu triplicar a produção e aumentar em $50 \%$ o número de funcionários, portanto a empresa obteve $300 \%$ de aumento na produtividade com apenas $50 \%$ de aumento de funcionários.

A empresa quis mudar porque ela percebeu que o mercado estava se comportando diferente e ela queria ter um diferencial em relação aos concorrentes.

1.2) Qual sua participação no mercado consumidor naquele momento?

Era líder de mercado em todas as suas principais linhas, em pulverizadores ela tem cerca de $70 \%$ e colhedeiras e adubadeiras cerca de $60 \%$ do mercado. Porém ela queria manter essa liderança e a solução seria a implementação do sistema Lean.

1.3) Os fatores motivadores para a mudança foram internos ou externos? Quais foram? Explique.

O fator foi externo, ou seja, o comportamento do mercado.

1.4) Qual(is) foi(ram) o(s) principal(is) agente(s) de mudança?

O principal agente foi o presidente da empresa. Na implementação formou-se uma equipe de 14 pessoas, as quais implementaram o projeto.

1.5) Houve ajuda de terceiros, como consultoria?

( x ) Sim. Como a empresa entrou em contato? Através do Lean Institute. Qual a razão da escolha? A empresa tinha participado do Lean Summit e ficaram motivados para implementar.

( ) Não. Como se deu a mudança internamente? Qual(is) o(s) método(s) utilizado(s)?

\section{Desenvolvimento e Implementação}

2.1) Qual a estratégia de implementação adotada? 
( x ) Implementação Piloto

( ) Implementação Programática

( ) Implementação Prototipal

Família de Pulverizadores (Condor)

2.2) Qual(is) foi(ram) a(s) principal(is) medida(s) tomada(s) quando começou a implementação da Produção Enxuta?

Formação da equipe

Treinamento do grupo e os funcionários do setor da montagem.

Implementação

2.3) Quais e quantos funcionários foram envolvidos na implementação?

A equipe era formada por 14 pessoas, dentre dessas, 1 era o líder (presidente da empresa) e as demais eram funcionários das diferentes áreas.

2.4) Quais foram os principais problemas encontrados no projeto e na implementação?

A empresa não encontrou grandes problemas, pois como o líder da equipe era o presidente da empresa, a equipe tinha total autonomia para executar as transformações necessárias.

2.5) Qual o investimento estimado na implementação da Produção Enxuta?

A empresa gastou com consultoria, treinamento e equipamentos. No período de 5 anos foi gasto cerca de 300 mil reais

2.6) O sistema de custeio dos produtos e do gerenciamento dos custos da empresa foi afetado pelo projeto de Produção Enxuta?

A empresa possuía um sistema de custeio e que ainda não foi mudado.

2.7) Após a implementação da Produção Enxuta, a empresa precisou modificar sua medida de desempenho de produção de máquinas/ operador?

A empresa não possui essa medida. Mas o projeto abordará.

2.8) A empresa utilizava algum sistema de medição de desempenho para setup? Após a implementação da Produção Enxuta este sistema foi alterado?

A empresa não possui essa medida. A preocupação está em fazer o fluxo fluir, e depois aplicar as métricas, porque quando ocorre o contrário, o processo fica engessado.

2.9) Qual era o takt time da operação antes da implementação da Produção Enxuta e qual é o atual?

A empresa não tinha takt time antes. Ela produzia com o sistema de produção em massa. Hoje, o takt é de 120 máquinas/dia. 
(A partir deste ponto o roteiro de entrevista irá apresentar algumas perguntas referentes às práticas da Produção Enxuta, com alternativas, por favor assinale aquela que mais se adequar a sua empresa)

\section{3) Práticas}

3.1)Quanto a utilização dos 5S, pode-se afirmar que trouxe impactos significativos para a empresa quanto a melhoria no ambiente de trabalho.

3.2) O 5S serviu de elemento inicial para a implementação base para a disseminação dos conceitos da Produção Enxuta na empresa.

3.3) A padronização do trabalho contribuiu para melhor utilização dos recursos da empresa.

3.4) A padronização do trabalho foi implementada extensivamente na empresa.

3.5) A utilização do Layout celular trouxe grandes mudanças no chão de fábrica quanto a disposição das máquinas e equipamentos.

3.6) O Layout celular foi utilizado extensivamente na empresa.

3.7) A utilização do Kanban trouxe agilidade nos processos produtivos quanto à necessidade de material ou de informações.

3.8) O Kanban foi utilizado extensivamente na empresa.

3.9) A utilização do Heijunka box ou o nivelamento de produção trouxe maior flexibilização e precisão na produção através de ajustes e reprogramação dos operadores.

3.10) Com a utilização do Mapa do Fluxo de Valor conseguiu-se visualizar e entender melhor todos os processos produtivos da empresa.

3.11) Com a utilização do Mapa do Fluxo de Valor, a empresa conseguiu tomar as melhores decisões e seguir um plano de ações estruturadas.

3.12) A utilização da Manutenção Produtiva Total trouxe diminuição nas paradas imprevistas de máquinas, facilitando atingir as metas de produção.

3.13) Com a utilização da Administração da Qualidade Total, os funcionários criaram um senso de responsabilidade e autoridade quanto à produção.

3.14) A Administração da Qualidade Total trouxe para a empresa redução nos custos da qualidade.

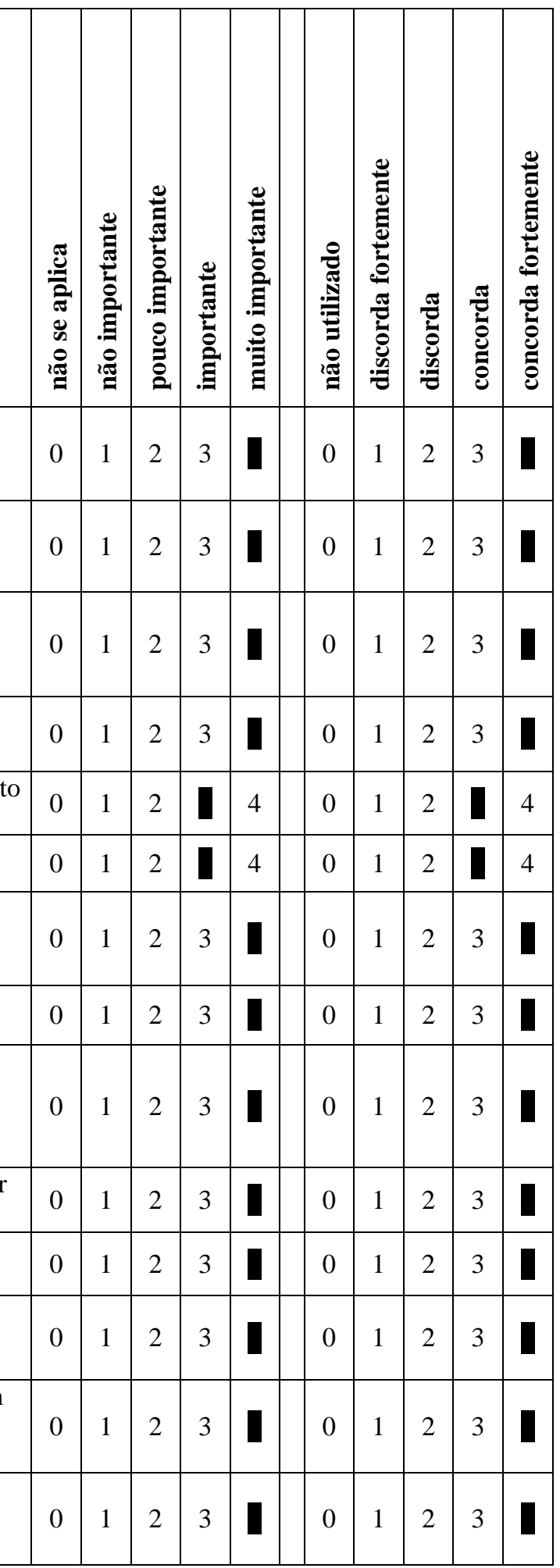




\section{Os Resultados Obtidos}

(Na tabela abaixo, assinale a alternativa que melhor exprima a realidade da empresa)

\begin{tabular}{|c|c|c|c|c|c|}
\hline $\begin{array}{l}\text { Quanto aos resultados obtidos devido ao uso da Produção Enxuta, a } \\
\text { empresa: }\end{array}$ & 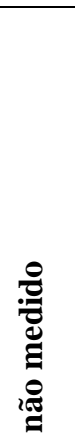 & 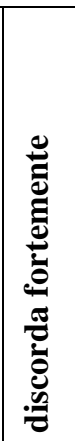 & 苞 & 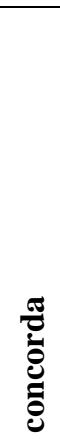 & 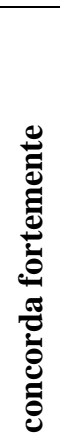 \\
\hline 4.1) Conseguiu melhorar sua produtividade em relação à produção/recursos/tempo. & 0 & 1 & 2 & 3 & \\
\hline $\begin{array}{l}\text { 4.2) Conseguiu melhorar o atendimento no prazo do pedido de seus clientes, ou seja, melhorou a } \\
\text { pontualidade de entrega. }\end{array}$ & 0 & 1 & 2 & 3 & \\
\hline 4.3) Conseguiu reduzir o lead time de fabricação. & 0 & 1 & 2 & 3 & \\
\hline 4.4) Conseguiu reduzir os custos de fabricação. & 0 & 1 & 2 & 3 & \\
\hline 4.5) Aumentou o faturamento. & 0 & 1 & 2 & 3 & \\
\hline 4.6) Aumentou a lucratividade. & 0 & 1 & 2 & 3 & \\
\hline 4.7) Diminuiu os estoques de matéria-prima. & D & 1 & 2 & 3 & 4 \\
\hline 4.8) Diminuiu os estoques de material em processo. & 0 & 1 & 2 & T & 4 \\
\hline 4.9) Diminuiu os estoques de produto acabado. & 0 & 1 & 2 & (1) & 4 \\
\hline $\begin{array}{l}\text { 4.10) Conseguiu reduzir a área de produção, por causa de rearranjos no layout do chão de } \\
\text { fábrica. }\end{array}$ & 0 & 1 & 2 & 3 & \\
\hline 4.11) Conseguiu reduzir a movimentação de material e pessoas. & 0 & 1 & 2 & 0 & 4 \\
\hline 4.12) Conseguiu aumentar sua participação no mercado consumidor. & 0 & 1 & T & 3 & 4 \\
\hline 4.13) Percebeu mudanças culturais em seus funcionários e no ambiente de trabalho. & 0 & 1 & 2 & 3 & \\
\hline 4.14) Influenciou significativamente a política de vendas/marketing. & 0 & 1 & 2 & 3 & \\
\hline 4.15) Mudou a política de desenvolvimento do produto. & D & 1 & 2 & 3 & 4 \\
\hline 4.16) Aumentou a qualidade de seus produtos. & 0 & 1 & 2 & 3 & \\
\hline 4.17) Aumentou o mix de produtos. & 0 & 1 & 2 & 3 & \\
\hline 4.18) Conseguiu influenciar seus fornecedores quanto à forma de entrega de material. & 0 & 1 & 2 & 1 & 4 \\
\hline 4.19) Aumentou o número de fornecedores. & 0 & 1 & T & 3 & 4 \\
\hline 4.20) Diminuiu o número de fornecedores. & 0 & 1 & 2 & 0 & 4 \\
\hline 4.21) Alterou seu fluxo de informações. & 0 & 1 & 2 & 3 & \\
\hline
\end{tabular}




\section{Comentários finais.}

\section{1) A empresa continua utilizando a Produção Enxuta?}

Sim. Há dois anos a empresa está tentando implementar o sistema Lean em outras áreas. O pessoal da administração, da exportação, da logística e de cortainers foi ao Lean Summit. Existe também um início trabalho na engenharia do produto. $\mathrm{O}$ foco do projeto Lean está na manufatura, não conseguindo expandir para os fornecedores. A meta é introduzir o Lean em sua plenitude até 2010, todas as áreas da empresa.

Quando início o projeto a primeira ação feita foi um planejamento da área de vendas com o pessoal da produção. Hoje a área comercial conversa com a produção antes de aceitar o pedido. Lead time de entrega de pedido é de 7 dias.

5.2) A empresa atribui os resultados positivos obtidos somente à implementação da Produção Enxuta? Comente.

Sim. Quando ocorreu o boom de mercado no agronegocio, o projeto Lean começou. Se não tivesse implementado naquele momento, eles não teriam atendido o mercado e consequentemente teriam perdido clientes.

5.3) Quais outras vantagens encontradas na Produção Enxuta ainda não abordadas neste roteiro de entrevista?

A Produção Enxuta traz vantagem competitiva para a empresa.

5.4) Quais outras desvantagens encontradas na Produção Enxuta ainda não abordadas neste roteiro de entrevista?

O sistema Lean precisa de estabilidade de mercado para funcionar bem e o ramo agrícola é muito sazonal, com períodos de safra intercalando com entressafra, consequentemente o projeto é afetado por essa sazonalidade..

5.5) Faça um comentário sobre um aspecto relacionado a esse assunto e que, possivelmente, não foi abordado (Se sentir necessidade).

Atualmente este é o melhor sistema de produção para as empresas em qualquer ramo ou setor.

Obrigada pela sua colaboração! 


\section{APÊNDICE E - RoteIro dE ENTREVISTA DA EMPRESA E}

\section{Roteiro de entrevista}

\section{Data: $22 / 02 / 2005$}

Nome da empresa: Empresa E

Ramo de atividade: Máquinas e implementos agrícolas

Produtos: 4 linhas de produtos: Plantio (Adubadoras e semeadoras), Colheita (Colhedeiras), Fertilizantes e transporte (Cultivadores), e Pecuária (Forrageiras, Desintegradores e Roçadeira)

Faturamento anual: 200 milhões de reais (em 2004)

Principais clientes: Grandes produtores, através das revendas localizadas em diversas regiões no mercado interno.

Para o mercado externo, a Venezuela tem uma grande participação no faturamento. No ano de 2004 , cerca de $15 \%$ do faturamento correspondeu ao mercado externo, sendo que a Venezuela foi responsável por cerca do $8 \%$. A empresa também vende para o México, que tem grande potencial e alguns produtos foram negociados na China, também com um grande potencial.

A empresa possui uma filial na África do Sul.

Principais concorrentes: Outras (multinacionais e pequenas empresas)

Número de funcionários: Aproximadamente 650 funcionários, entre mão-de-obra direta e indireta.

Entrevistado: Vitor Cássio Soares

Cargo: Gerente de Produção e Gerente do Projeto Lean 


\section{Histórico}

\section{1) Quando e por que a empresa começou a utilizar a Produção Enxuta?}

O projeto começou em fevereiro de 2003. A demanda era alta pelos produtos e a empresa não conseguia suprir. Existia muito desbalanceamento na linha de produção. Existe um item de controle da empresa que é Suprimentos, que envolve todo o gasto para se produzir, menos a folha de pagamento e comissão do vendedor. Ele possui um limite de $55 \%$ do valor do faturamento Este índice sempre ficou muito alterado, ultrapassando $100 \%$, ou seja, a empresa gastava alem do que estava faturando no período. A consequiência era que a empresa comprava de maneira antecipada e desbalanceada, gerando um problema de fluxo de caixa.

1.2) Qual sua participação no mercado consumidor naquele momento?

Este dado não foi fornecido.

1.3) Os fatores motivadores para a mudança foram internos ou externos? Quais foram? Explique.

Os fatores foram internos. O cenário era uma enorme demanda, uma produção alta, produtividade era baixa e havia muita atividade que não agregava valor, com muitos desperdícios. Com isso a empresa precisava fazer empréstimos. A grande dificuldade era controlar os níveis de estoques e aumentar a produtividade. Vimos que a produção enxuta atacava exatamente o problema raiz, que são as atividades que não agregam valor. A empresa também precisava melhorar seu processo produtivo, mas o maior desperdício estava nas movimentações desnecessárias que existiam, como ficar movimentando as peças de um lado para o outro e gastando com o pessoal para administrar os estoques.

A empresa já trabalhava com Kanban, e tinha muitos supermercados. O problema raiz identificado foi a eliminação de alguns supermercados, por causa de estoques e para facilitar a fábrica ficar mais flexível, acompanhando melhor a variação de demanda. Neste caso existia a má utilização do sistema kanban. A empresa tinha e tem um setor responsável pelo envio das peças para os fornecedores terceirizados, para fazer a industrialização dessas peças. No momento de envio, existem 2 setores primários que fornecem peças (serras e fundição), que nestes postos de kanban é chamado de recebimento (um painel de kanban enorme, que era abastecido pelos outros dois painéis da serra e da fundição). Muitas vezes, neste setor entrava um item no vermelho, no setor de recebimento, ele disparava para a serra, mas às vezes este item estava em estoque e era atendido prontamente. Porém quando ocorria de entrar um item no vermelho, e ele disparava para a serra e lá o item estava no vermelho, o responsável pelo setor das serras, iria tratar este item, mas ele também tinha suas prioridades no seu quadro de kanban, que muitas vezes ficava conflitando. Isto também ocorria na fundição.

A empresa identificou a questão do TPT, a cada 3 dias seria suficiente para a serra fazer todos seus itens. A empresa eliminou o kanban da serra, e passou a fazer contra pedido, conforme entrava no disparo do recebimento. E na fundição ocorreu o mesmo.

1.4) Qual(is) foi(ram) o(s) principal(is) agente(s) de mudança? 
O primeiro contato com o sistema Lean, foi através do pessoal do Lean Institute com Fabrício Rosa de Morais, presidente da empresa, que percebeu através do livro "Aprendendo a enxergar", a necessidade de melhorar, mas não queria fazer grandes investimentos, sendo ele o principal agente de mudança.

1.5) Houve ajuda de terceiros, como consultoria?

( $x$ ) Sim. Como a empresa entrou em contato? A empresa tomou conhecimento de uma implementação em outra empresa e entrou em contato diretamente. Qual a razão da escolha? A principal razão foi a proposta.

( ) Não. Como se deu a mudança internamente? Qual(is) o(s) método(s) utilizado(s)?

\section{Desenvolvimento e Implementação}

2.1) Qual a estratégia de implementação adotada?

( ) Implementação Piloto

( ) Implementação Programática

( x ) Implementação Prototipal

2.2) Qual(is) foi(ram) a(s) principal(is) medida(s) tomada(s) quando começou a implementação da Produção Enxuta?

Inicialmente foi formada uma equipe, com um líder e seus membros.

Depois começaram os treinamentos para todos os funcionários e principais fornecedores.

Posteriormente o pessoal da equipe passou por outro treinamento dos conceitos.

Implementação. No primeiro mapeamento do fluxo de valor foi identificado que o principal problema era a expedição (montagem e entrega).

2.3) Quais e quantos funcionários foram envolvidos na implementação?

A equipe contava com um funcionário do PCP, dois de tempos e métodos, um da engenharia de processos, seis da ferramentaria.

2.4) Quais foram os principais problemas encontrados no projeto e na implementação?

Inicialmente, nos treinamentos participaram os gerentes e supervisores. Houve a principio, uma morosidade por causa do entendimento dos conceitos e questionamento se seria viável o projeto.

2.5) Qual o investimento estimado na implementação da Produção Enxuta?

O investimento foi de aproximadamente $\mathrm{R} \$ 120.000,00$, gastados com uma empilhadeira elétrica, material para fazer pallets e consultoria.

2.6) O sistema de custeio dos produtos e do gerenciamento dos custos da empresa foi afetado pelo projeto de Produção Enxuta?

O sistema de custeio ainda não foi alterado. O próximo trabalho será trabalhar este sistema 
A empresa possui um índice de Produtividade Industrial, que de 2002 para 2004 aumentou $25 \%$. .

2.7) Após a implementação da Produção Enxuta, a empresa precisou modificar sua medida de desempenho de produção de máquinas/ operador?

A empresa possui um sistema chamado GPD: Gerenciamento Pelas Diretrizes, que os itens de controles fornecem prêmios para os funcionários por participação de resultados. O item de controle, hoje adotado, é o item de produtividade geral, liquidez por operador: o faturamento - o gasto (suprimentos) / folha de pagamento + encargos. Em fevereiro de 2003 era de 1 e passou em dezembro de 2004 para 3.

2.8) A empresa utilizava algum sistema de medição de desempenho para setup? Após a implementação da Produção Enxuta este sistema foi alterado?

Quando a empresa começou a implementar o kanban, no setor de estamparia foram feitas algumas técnicas de redução de setup, onde uma pessoa filmava aquele setup, e uma equipe analisava e propunha melhorias. Este trabalho continua até hoje e houve a padronização de chaves, parafusos, etc.

Com a Produção Enxuta houve redução do setup de solda. Antes era em torno de 30 min, e foi para 5 min, juntamente com a padronização.

2.9) Qual era o takt time da operação antes da implementação da Produção Enxuta e qual é o atual?

Em 2003 era de 45 min por máquina

Em 2004 foi de 30 min por máquina, mas hoje não existe demanda por fatores externos: falta de financiamentos e a economia global. 
(A partir deste ponto o roteiro de entrevista irá apresentar algumas perguntas referentes às práticas da Produção Enxuta, com alternativas, por favor assinale aquela que mais se adequar a sua empresa)

\section{3) Práticas}

3.1)Quanto a utilização dos 5S, pode-se afirmar que trouxe impactos significativos para a empresa quanto a melhoria no ambiente de trabalho.

3.2) O 5S serviu de elemento inicial para a implementação base para a disseminação dos conceitos da Produção Enxuta na empresa.

3.3) A padronização do trabalho contribuiu para melhor utilização dos recursos da empresa.

3.4) A padronização do trabalho foi implementada extensivamente na empresa.

3.5) A utilização do Layout celular trouxe grandes mudanças no chão de fábrica quanto a disposição das máquinas e equipamentos.

3.6) O Layout celular foi utilizado extensivamente na empresa.

3.7) A utilização do Kanban trouxe agilidade nos processos produtivos quanto à necessidade de material ou de informações.

3.8) O Kanban foi utilizado extensivamente na empresa.

3.9) A utilização do Heijunka box ou o nivelamento de produção trouxe maior flexibilização e precisão na produção através de ajustes e reprogramação dos operadores.

3.10) Com a utilização do Mapa do Fluxo de Valor conseguiu-se visualizar e entender melhor todos os processos produtivos da empresa.

3.11) Com a utilização do Mapa do Fluxo de Valor, a empresa conseguiu tomar as melhores decisões e seguir um plano de ações estruturadas.

3.12) A utilização da Manutenção Produtiva Total trouxe diminuição nas paradas imprevistas de máquinas, facilitando atingir as metas de produção.

3.13) Com a utilização da Administração da Qualidade Total, os funcionários criaram um senso de responsabilidade e autoridade quanto à produção.

3.14) A Administração da Qualidade Total trouxe para a empresa redução nos custos da qualidade.

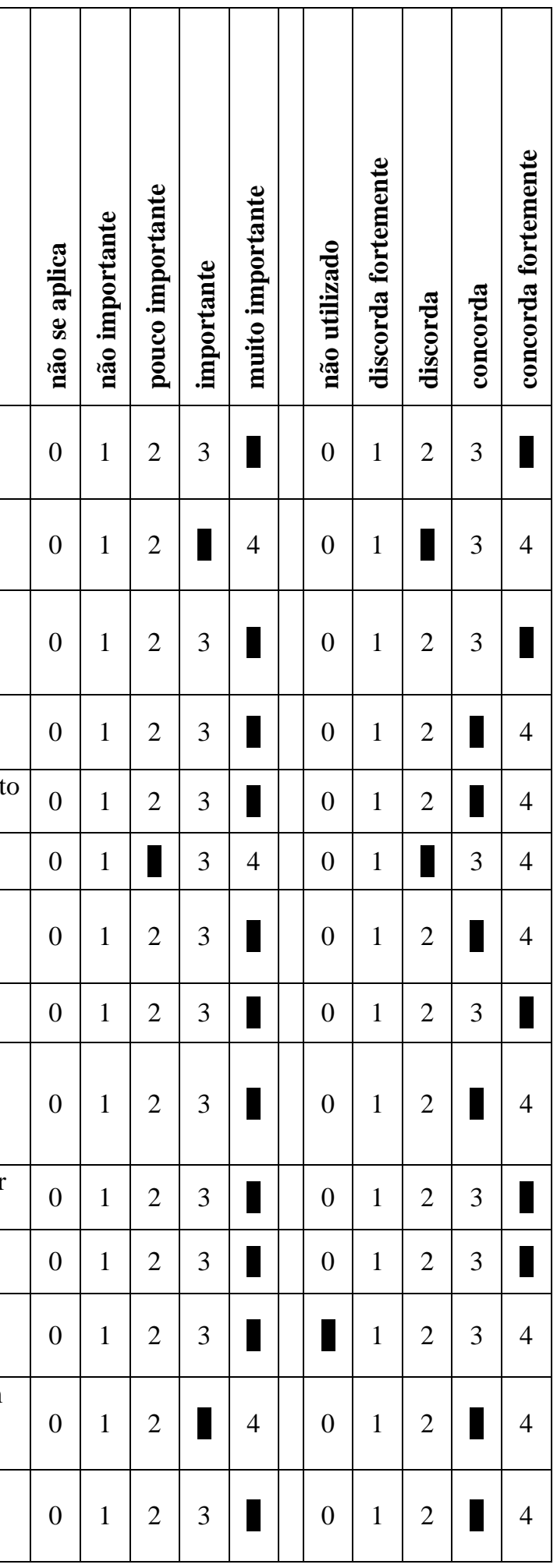




\section{Os Resultados Obtidos}

(Na tabela abaixo, assinale a alternativa que melhor exprima a realidade da empresa)

\begin{tabular}{|c|c|c|c|c|c|}
\hline $\begin{array}{l}\text { Quanto aos resultados obtidos devido ao uso da Produção Enxuta, a } \\
\text { empresa: }\end{array}$ & 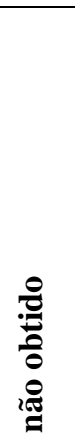 & 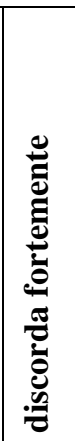 & 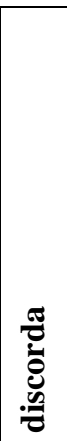 & 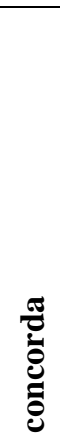 & 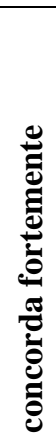 \\
\hline 4.1) Conseguiu melhorar sua produtividade em relação à produção/recursos/tempo. & 0 & 1 & 2 & 3 & \\
\hline $\begin{array}{l}\text { 4.2) Conseguiu melhorar o atendimento no prazo do pedido de seus clientes, ou seja, melhorou a } \\
\text { pontualidade de entrega. }\end{array}$ & 0 & 1 & 2 & ] & 4 \\
\hline 4.3) Conseguiu reduzir o lead time de fabricação. & 0 & 1 & 2 & & 4 \\
\hline 4.4) Conseguiu reduzir os custos de fabricação. & 0 & 1 & 2 & & 4 \\
\hline 4.5) Aumentou o faturamento. & 0 & 1 & 2 & & 4 \\
\hline 4.6) Aumentou a lucratividade. & 0 & 1 & 2 & 3 & \\
\hline 4.7) Diminuiu os estoques de matéria-prima. & 0 & 1 & 2 & 3 & \\
\hline 4.8) Diminuiu os estoques de material em processo. & 0 & 1 & 2 & 3 & \\
\hline 4.9) Diminuiu os estoques de produto acabado. & 0 & 1 & 2 & 3 & \\
\hline $\begin{array}{l}\text { 4.10) Conseguiu reduzir a área de produção, por causa de rearranjos no layout do chão de } \\
\text { fábrica. }\end{array}$ & 0 & 1 & 2 & 3 & \\
\hline 4.11) Conseguiu reduzir a movimentação de material e pessoas. & 0 & 1 & 2 & 3 & \\
\hline 4.12) Conseguiu aumentar sua participação no mercado consumidor. & 0 & 1 & 2 & 3 & \\
\hline 4.13) Percebeu mudanças culturais em seus funcionários e no ambiente de trabalho. & 0 & 1 & 2 & & 4 \\
\hline 4.14) Influenciou significativamente a política de vendas/marketing. & 0 & 1 & 2 & & 4 \\
\hline 4.15) Mudou a política de desenvolvimento do produto. & 0 & 1 & 2 & & 4 \\
\hline 4.16) Aumentou a qualidade de seus produtos. & 0 & 1 & 2 & & 4 \\
\hline 4.17) Aumentou o mix de produtos. & 0 & 1 & 2 & & 4 \\
\hline 4.18) Conseguiu influenciar seus fornecedores quanto à forma de entrega de material. & 0 & 1 & 2 & & 4 \\
\hline 4.19) Aumentou o número de fornecedores. & 0 & 1 & 2 & & 4 \\
\hline 4.20) Diminuiu o número de fornecedores. & 0 & 1 & ] & 3 & 4 \\
\hline 4.21) Alterou seu fluxo de informações. & 0 & 1 & 2 & & 4 \\
\hline
\end{tabular}




\section{Comentários finais.}

\section{1) A empresa continua utilizando a Produção Enxuta?}

Sim. Continua o projeto, dando continuidade com um projeto de uma nova fábrica.

5.2) A empresa atribui os resultados positivos obtidos somente à implementação da Produção Enxuta? Comente.

Sim. Desde o momento de adoção do sistema Lean, as pessoas que participaram começaram a ter uma visão diferente, mesmo que essas melhorias muitas vezes até não foram evidenciadas nos cronogramas.

5.3) Quais outras vantagens encontradas na Produção Enxuta ainda não abordadas neste roteiro de entrevista?

A cultura organizacional foi muito alterada. Os funcionários trabalhavam com alta pressão, estresse e com confronto com o pessoal de vendas.

5.4) Quais outras desvantagens encontradas na Produção Enxuta ainda não abordadas neste roteiro de entrevista?

Grande dificuldade está em capacitar as pessoas para este processo e motivá-las, mantendo o projeto.

5.5) Faça um comentário sobre um aspecto relacionado a esse assunto e que, possivelmente, não foi abordado (Se sentir necessidade).

(sem comentários)

Obrigada pela sua colaboração! 


\section{APÊNDICE F - RoteIro dE ENTREVISTA dA EMPRESA F}

\section{Roteiro de entrevista}

Data: $09 / 03 \quad / 2005$

Nome da empresa: Empresa F

Ramo de atividade: Máquinas agrícolas

Produtos: Pulverizadores e Atomizadores (pulverizadores motorizados para cultura de café, uva e maçã)

Faturamento: Dado não fornecido

Principais clientes: A empresa realiza suas vendas através de revendas ou representantes comerciais. As vendas externas são feitas diretamente através do contato com a empresa.

Principais concorrentes: Empresas D e I

Número de funcionários: aproximadamente 80 funcionários

Entrevistado: Wellington José Okasaoara

Cargo: Gerente de Produção/ Gerente do Projeto

\section{Histórico}

1.1) Quando e por que a empresa começou a utilizar a Produção Enxuta?

O projeto começou em março de 2004. Nesta época a empresa estava produzindo bastante, pois seus produtos estavam com uma alta demanda. E a motivação para a mudança surgiu justamente quando participei de um evento da CSMIA- ABIMAQ, e entramos em contato com os casos apresentados. A empresa queria criar uma organização e implementar um sistema controle sobre a produção. 
1.2) Qual sua participação no mercado consumidor naquele momento?

A empresa está na posição de $3^{\circ}$ lugar no ranking nacional de pulverizadores e atomizadores.

1.3) Os fatores motivadores para a mudança foram internos ou externos? Quais foram? Explique.

Os problemas foram internos. A empresa queria fazer mais com o mesmo. Problemas com a produção motivaram a necessidade de kanban para o controle. A produção era muito desorganizada.

1.4) Qual(is) foi(ram) o(s) principal(is) agente(s) de mudança?

A iniciativa foi dada pela diretoria (presidente), na ocasião do evento.

1.5) Houve ajuda de terceiros, como consultoria?

( X ) Sim. Como a empresa entrou em contato? O primeiro contato foi no evento da ABIMAQ, em 2003. Qual a razão da escolha? A proposta de trabalho foi boa.

( ) Não. Como se deu a mudança internamente? Qual(is) o(s) método(s) utilizado(s)?

\section{Desenvolvimento e Implementação}

2.1) Qual a estratégia de implementação adotada?

( X ) Implementação Piloto

( ) Implementação Programática

( ) Implementação Prototipal

A empresa ao iniciar o projeto Lean, identificou-se 4 famílias de máquinas, e a escolhida foi um pulverizador.

2.2) Qual(is) foi(ram) a(s) principal(is) medida(s) tomada(s) quando começou a implementação da Produção Enxuta?

Formação da equipe do projeto

Treinamento prévio desta equipe para a explicação do projeto.

Implementação, com o levantamento dos dados necessários para o projeto. Esta era uma carência na empresa, a falta de dados consistentes. Paralelamente foram feitas organizações como a contagem dos estoques.

2.3) Quais e quantos funcionários foram envolvidos na implementação?

A equipe era formada pelo gerente do projeto e um encarregado de usinagem, um de solda, um de montagem e um de injeção, além dos consultores. A equipe também contava com alguns auxiliares, como os três abastecedores, responsáveis pelo abastecimento das linhas de produção.

2.4) Quais foram os principais problemas encontrados no projeto e na implementação? 
No inicio do projeto já houve a necessidade de alguns dados que a empresa não possuía, o que acabou dificultando um ritmo mais rápido. A princípio houve a necessidade de deixar cada funcionário se familiarizar com os conceitos passados, pois a mudança organizacional é lenta para ser assimilada.

Houveram rearranjos no layout da fábrica, foram criadas muitas prateleiras, divisórias, não caracterizando como um problema, mas tempo exigido.

\section{5) Qual o investimento estimado na implementação da Produção Enxuta?}

Dado não fornecido.

2.6) O sistema de custeio dos produtos e do gerenciamento dos custos da empresa foi afetado pelo projeto de Produção Enxuta?

A empresa está trabalhando em um projeto de custos em paralelo ao projeto Lean, mas ainda não houveram mudanças. Porém as informações do projeto Lean ajudaram no projeto de custos.

2.7) Após a implementação da Produção Enxuta, a empresa precisou modificar sua medida de desempenho de produção de máquinas/ operador?

Historicamente, na empresa não existia a cultura de medição de dados. Há apenas 3 anos, a empresa vem coletando os alguns tipos de dados para estruturar melhor seus processos. A área de vendas possuía um banco de dados estruturado, porém a área de produção não tinha. Tanto que no inicio do projeto Lean as maiores dificuldades foram justamente os tempos de ciclo, setup, etc.. A variedade de peças é muito grande, e a empresa não tinha um cronometrista para ficar medindo. Com o projeto Lean gerou-se a necessidade de medição e o processo foi começado, mas isto está em um nível menor de prioridade.

2.8) A empresa utilizava algum sistema de medição de desempenho para setup? Após a implementação da Produção Enxuta este sistema foi alterado?

Não havia medição de setup, exceto na área de injetora. A área de injeção de material plástico é a mais organizada da empresa. Até pelo próprio processo de injeção que favorece a medição. Depois com o Projeto Lean foi feito um levantamento do setup com base em informações passadas pelo funcionário encarregado do processo. Ainda o projeto não chegou nesta etapa. O sistema Lean favoreceu a questão do setup, porque se começou a enxergar a necessidade e a mudança do layout favoreceu. Hoje o layout favoreceu a movimentação e despertou para este problema.

2.9) Qual era o takt time da operação antes da implementação da Produção Enxuta e qual é o atual?

Para a família estudada, máquina pulverizadora de três pontos manuais, inicialmente o takt time era de 111 minutos, e hoje está em 73 min. 
(A partir deste ponto o roteiro de entrevista irá apresentar algumas perguntas referentes às práticas da Produção Enxuta, com alternativas, por favor assinale aquela que mais se adequar a sua empresa)

\section{3) Práticas}

3.1)Quanto a utilização dos 5S, pode-se afirmar que trouxe impactos significativos para a empresa quanto a melhoria no ambiente de trabalho.

3.2) O 5S serviu de elemento inicial para a implementação base para a disseminação dos conceitos da Produção Enxuta na empresa.

3.3) A padronização do trabalho contribuiu para melhor utilização dos recursos da empresa.

3.4) A padronização do trabalho foi implementada extensivamente na empresa.

3.5) A utilização do Layout celular trouxe grandes mudanças no chão de fábrica quanto a disposição das máquinas e equipamentos.

3.6) O Layout celular foi utilizado extensivamente na empresa.

3.7) A utilização do Kanban trouxe agilidade nos processos produtivos quanto à necessidade de material ou de informações.

3.8) O Kanban foi utilizado extensivamente na empresa.

3.9) A utilização do Heijunka box ou o nivelamento de produção trouxe maior flexibilização e precisão na produção através de ajustes e reprogramação dos operadores.

3.10) Com a utilização do Mapa do Fluxo de Valor conseguiu-se visualizar e entender melhor todos os processos produtivos da empresa.

3.11) Com a utilização do Mapa do Fluxo de Valor, a empresa conseguiu tomar as melhores decisões e seguir um plano de ações estruturadas.

3.12) A utilização da Manutenção Produtiva Total trouxe diminuição nas paradas imprevistas de máquinas, facilitando atingir as metas de produção.

3.13) Com a utilização da Administração da Qualidade Total, os funcionários criaram um senso de responsabilidade e autoridade quanto à produção.

3.14) A Administração da Qualidade Total trouxe para a empresa redução nos custos da qualidade.

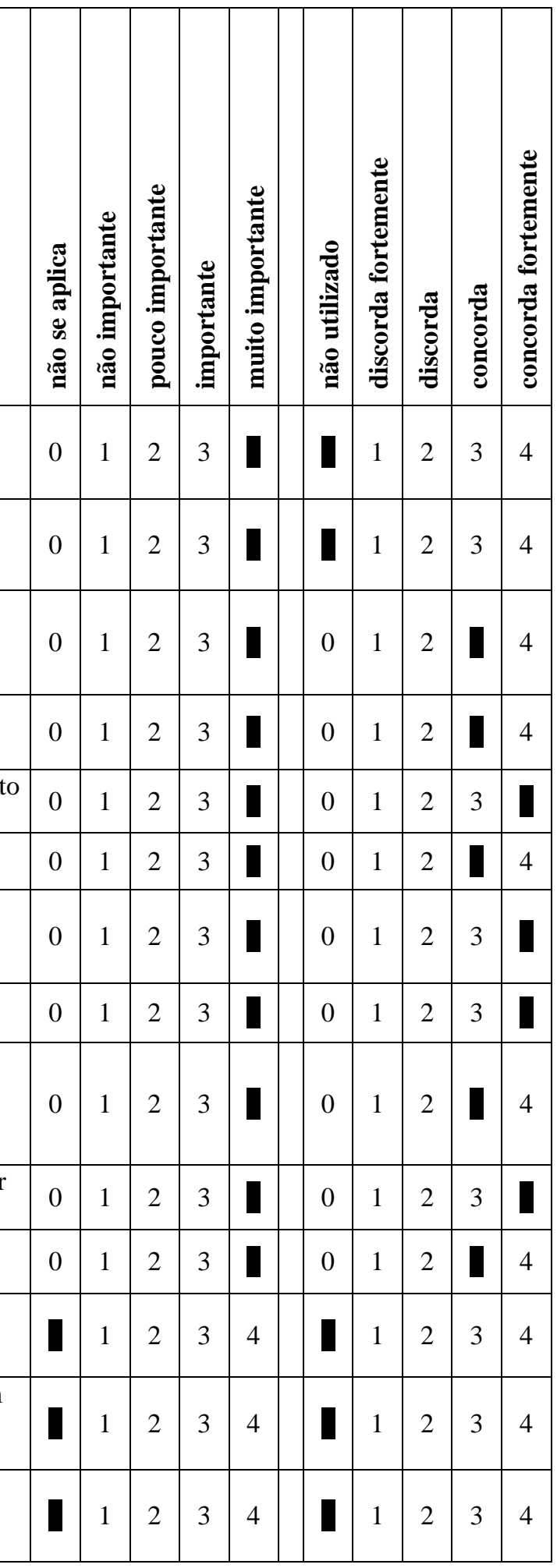




\section{Os Resultados Obtidos}

(Na tabela abaixo, assinale a alternativa que melhor exprima a realidade da empresa)

\begin{tabular}{|c|c|c|c|c|c|}
\hline $\begin{array}{l}\text { Quanto aos resultados obtidos devido ao uso da Produção Enxuta, a } \\
\text { empresa: }\end{array}$ & 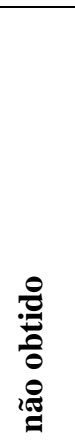 & 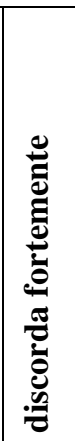 & 总 & 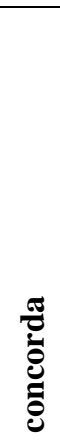 & 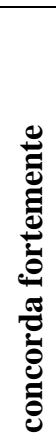 \\
\hline 4.1) Conseguiu melhorar sua produtividade em relação à produção/recursos/tempo. & 0 & 1 & 2 & 3 & \\
\hline $\begin{array}{l}\text { 4.2) Conseguiu melhorar o atendimento no prazo do pedido de seus clientes, ou seja, melhorou a } \\
\text { pontualidade de entrega. }\end{array}$ & 0 & 1 & 2 & 3 & \\
\hline 4.3) Conseguiu reduzir o lead time de fabricação. & 0 & 1 & 2 & 3 & \\
\hline 4.4) Conseguiu reduzir os custos de fabricação. & & 1 & 2 & 3 & 4 \\
\hline 4.5) Aumentou o faturamento. & & 1 & 2 & 3 & 4 \\
\hline 4.6) Aumentou a lucratividade. & 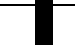 & 1 & 2 & 3 & 4 \\
\hline 4.7) Diminuiu os estoques de matéria-prima. & 0 & 1 & 2 & 3 & \\
\hline 4.8) Diminuiu os estoques de material em processo. & 0 & 1 & 2 & 3 & \\
\hline 4.9) Diminuiu os estoques de produto acabado. & 0 & 1 & 2 & 3 & \\
\hline $\begin{array}{l}\text { 4.10) Conseguiu reduzir a área de produção, por causa de rearranjos no layout do chão de } \\
\text { fábrica. }\end{array}$ & 0 & 1 & 2 & 3 & \\
\hline 4.11) Conseguiu reduzir a movimentação de material e pessoas. & 0 & 1 & 2 & 3 & \\
\hline 4.12) Conseguiu aumentar sua participação no mercado consumidor. & T & 1 & 2 & 3 & 4 \\
\hline 4.13) Percebeu mudanças culturais em seus funcionários e no ambiente de trabalho. & 0 & 1 & 2 & & 4 \\
\hline 4.14) Influenciou significativamente a política de vendas/marketing. & 0 & 1 & 2 & & 4 \\
\hline 4.15) Mudou a política de desenvolvimento do produto. & 0 & 1 & 2 & & 4 \\
\hline 4.16) Aumentou a qualidade de seus produtos. & & 1 & 2 & 3 & 4 \\
\hline 4.17) Aumentou o mix de produtos. & & 1 & 2 & 3 & 4 \\
\hline 4.18) Conseguiu influenciar seus fornecedores quanto à forma de entrega de material. & & 1 & 2 & 3 & 4 \\
\hline 4.19) Aumentou o número de fornecedores. & & 1 & 2 & 3 & 4 \\
\hline 4.20) Diminuiu o número de fornecedores. & 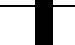 & 1 & 2 & 3 & 4 \\
\hline 4.21) Alterou seu fluxo de informações. & 0 & 1 & 2 & 3 & \\
\hline
\end{tabular}




\section{Comentários finais.}

\section{1) A empresa continua utilizando a Produção Enxuta?}

Sim. Mesmo sem a presença da consultoria, a empresa quer dar continuidade ao projeto e não perder o que foi implementado. Priorizar o sistema Lean para enraizar os conceitos.

5.2) A empresa atribui os resultados positivos obtidos somente à implementação da Produção Enxuta? Comente.

Sim, totalmente.

5.3) Quais outras vantagens encontradas na Produção Enxuta ainda não abordadas neste roteiro de entrevista?

Não

5.4) Quais outras desvantagens encontradas na Produção Enxuta ainda não abordadas neste roteiro de entrevista?

Nenhuma, porque a quantidade de benefícios é enorme.

5.5) Faça um comentário sobre um aspecto relacionado a esse assunto e que, possivelmente, não foi abordado (Se sentir necessidade).

Não.

Obrigada pela sua colaboração! 


\section{APÊNDICE G - ROTEIRO DE ENTREVISTA DA EMPRESA G}

\section{Roteiro de entrevista}

\section{Data: $28 / 04 / 2005$}

Nome da empresa: Empresa G

Ramo de atividade: Máquinas e Implementos Agropecuários

Produtos: Colheitadeiras de Forragem e Trituradores

Faturamento: Em 2004 cerca de 15 milhões de reais anuais

Principais clientes: A empresa vende seus produtos através de revendas. As exportações são feitas através de representantes comerciais, apenas no México, a empresa tem uma parceria com uma revenda.

Principais concorrentes: Empresas A, B e outras.

Número de funcionários: aproximadamente 85 funcionários

Entrevistado: Gilson Pereira Conceição e Antonio Sérgio Capoli

Cargo: Gerente de Desenvolvimento de Projeto e Gerente de desenvolvimento de produção, respectivamente. No projeto Lean os dois coordenam o trabalho.

\section{Histórico}

1.1) Quando e por que a empresa começou a utilizar a Produção Enxuta?

Começou em agosto de 2004. A empresa tinha feito um trabalho, anteriormente ao projeto, de $5 \mathrm{~S}$ e arranjo do layout em célula, que foi o fundamental para a empresa. A empresa trabalhava em sistema de produção em lote e o diretor devido a ter contato com outras empresas teve conhecimento do desempenho delas com o sistema Lean e resolveu conhecer melhor, mandando alguns funcionários na empresa D para fazerem 
um tipo de estágio. A empresa tinha muito estoque parado, e não conseguia pagar seus funcionários. O que motivou também foi a maneira organizada de se produzir.

1.2) Qual sua participação no mercado consumidor naquele momento?

A empresa tinha $20 \%$. Hoje tem uma fatia de mercado por volta de $40 \%$ (na família estudada no projeto).

1.3) Os fatores motivadores para a mudança foram internos ou externos? Quais foram? Explique.

O principal fator externo foi que a empresa queria ganhar mercado, aumentando sua participação pelo atendimento mais rápido do cliente.

$\mathrm{O}$ principal fator interno foi que a empresa tinha altos estoques e a produção não era organizada.

1.4) Qual(is) foi(ram) o(s) principal(is) agente(s) de mudança?

O diretor foi o principal motivador do projeto, porém a responsabilidade passou para os dois funcionários em questão.

1.5) Houve ajuda de terceiros, como consultoria?

( $\mathrm{x}$ ) Sim. Como a empresa entrou em contato? Através do contato do diretor com a empresa D ele entrou em contato com o consultor. Qual a razão da escolha? Recomendação da outra empresa.

( ) Não. Como se deu a mudança internamente? Qual(is) o(s) método(s) utilizado(s)?

\section{Desenvolvimento e Implementação}

2.1) Qual a estratégia de implementação adotada?

( $\mathrm{x}$ ) Implementação Piloto

( ) Implementação Programática

( ) Implementação Prototipal

Família de colheitadeira de forragem (Premium)

2.2) Qual(is) foi(ram) a(s) principal(is) medida(s) tomada(s) quando começou a implementação da Produção Enxuta?

Formou-se um grupo com 7 pessoas.

Os conceitos foram passados através da palestras. Treinamentos. Recentemente os funcionários de chão de fábrica estão participando dos treinamentos.

Implementação

2.3) Quais e quantos funcionários foram envolvidos na implementação?

A equipe é formada por 7 pessoas das áreas: de projetos, corte, prensa, montagem e desenvolvimento de produção. 
2.4) Quais foram os principais problemas encontrados no projeto e na implementação?

A conscientização dos funcionários a respeito da mudança. O sistema Lean é organizado, e eles tinham que se adaptarem. Outro problema foi o gerenciamento da empresa que estava tendo a produção no sistema em lote e implementando o sistema Lean em paralelo. Os funcionários ficaram confusos. A empresa também está fazendo a codificação das peças, já que não existia.

2.5) Qual o investimento estimado na implementação da Produção Enxuta?

A empresa gastou cerca de $\mathrm{R} \$ 5.000,00$ até o presente momento com consultoria e utilizou recursos próprios para fazer os palletes, prateleiras, cartões, etc..

2.6) O sistema de custeio dos produtos e do gerenciamento dos custos da empresa foi afetado pelo projeto de Produção Enxuta?

A empresa não possui um sistema de custeio. Mas está sendo feito um trabalho de catalogação de todas as peças e colocando em um sistema informatizado. A empresa tem planos de fazer este estudo assim que finalizar esta etapa.

2.7) Após a implementação da Produção Enxuta, a empresa precisou modificar sua medida de desempenho de produção de máquinas/ operador?

Não tinha. O projeto ainda não conseguiu medir.

2.8) A empresa utilizava algum sistema de medição de desempenho para setup? Após a implementação da Produção Enxuta este sistema foi alterado?

A empresa tem problemas com a redução de setup. E também o projeto ainda não abordou. O projeto ajudou a enxergar a necessidade de medir e depois melhorar.

2.9) Qual era o takt time da operação antes da implementação da Produção Enxuta e qual é o atual?

Não tinha, os funcionários estimavam. Antes era mais ou menos de 3 horas. Hoje é de 1 hora $45 \mathrm{~min}$. 
(A partir deste ponto o roteiro de entrevista irá apresentar algumas perguntas referentes às práticas da Produção Enxuta, com alternativas, por favor assinale aquela que mais se adequar a sua empresa)

\section{3) Práticas}

3.1)Quanto a utilização dos 5S, pode-se afirmar que trouxe impactos significativos para a empresa quanto a melhoria no ambiente de trabalho.

3.2) O 5S serviu de elemento inicial para a implementação base para a disseminação dos conceitos da Produção Enxuta na empresa.

3.3) A padronização do trabalho contribuiu para melhor utilização dos recursos da empresa.

3.4) A padronização do trabalho foi implementada extensivamente na empresa.

3.5) A utilização do Layout celular trouxe grandes mudanças no chão de fábrica quanto a disposição das máquinas e equipamentos.

3.6) O Layout celular foi utilizado extensivamente na empresa.

3.7) A utilização do Kanban trouxe agilidade nos processos produtivos quanto à necessidade de material ou de informações.

3.8) O Kanban foi utilizado extensivamente na empresa.

3.9) A utilização do Heijunka box ou o nivelamento de produção trouxe maior flexibilização e precisão na produção através de ajustes e reprogramação dos operadores.

3.10) Com a utilização do Mapa do Fluxo de Valor conseguiu-se visualizar e entender melhor todos os processos produtivos da empresa.

3.11) Com a utilização do Mapa do Fluxo de Valor, a empresa conseguiu tomar as melhores decisões e seguir um plano de ações estruturadas.

3.12) A utilização da Manutenção Produtiva Total trouxe diminuição nas paradas imprevistas de máquinas, facilitando atingir as metas de produção.

3.13) Com a utilização da Administração da Qualidade Total, os funcionários criaram um senso de responsabilidade e autoridade quanto à produção.

3.14) A Administração da Qualidade Total trouxe para a empresa redução nos custos da qualidade.

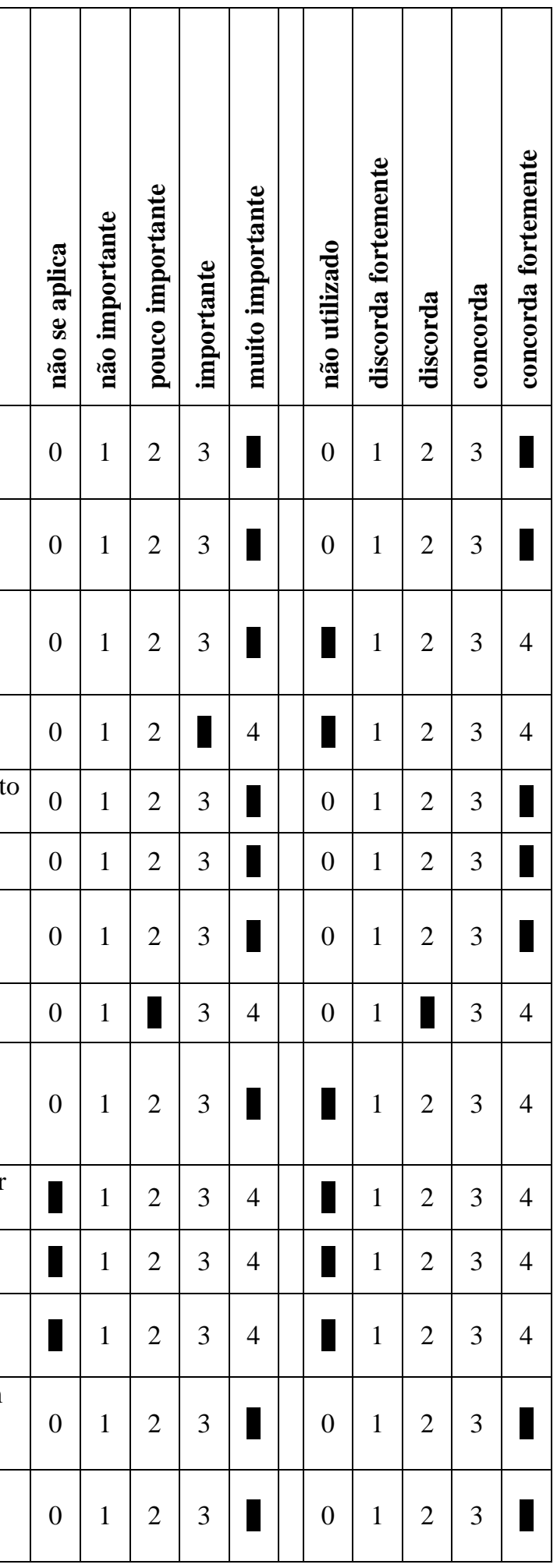




\section{Os Resultados Obtidos}

(Na tabela abaixo, assinale a alternativa que melhor exprima a realidade da empresa)

\begin{tabular}{|c|c|c|c|c|c|}
\hline $\begin{array}{l}\text { Quanto aos resultados obtidos devido ao uso da Produção Enxuta, a } \\
\text { empresa: }\end{array}$ & 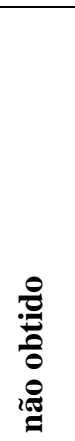 & 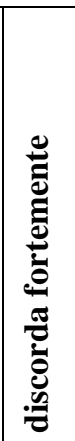 & 苞 & 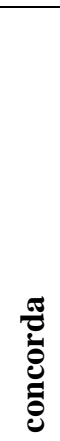 & 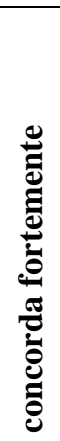 \\
\hline 4.1) Conseguiu melhorar sua produtividade em relação à produção/recursos/tempo. & 0 & 1 & 2 & 7 & 4 \\
\hline $\begin{array}{l}\text { 4.2) Conseguiu melhorar o atendimento no prazo do pedido de seus clientes, ou seja, melhorou a } \\
\text { pontualidade de entrega. }\end{array}$ & 0 & 1 & 2 & 3 & \\
\hline 4.3) Conseguiu reduzir o lead time de fabricação. & 0 & 1 & 2 & 3 & \\
\hline 4.4) Conseguiu reduzir os custos de fabricação. & D & 1 & 2 & 3 & 4 \\
\hline 4.5) Aumentou o faturamento. & 0 & 1 & 2 & T & 4 \\
\hline 4.6) Aumentou a lucratividade. & 0 & 1 & 2 & 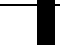 & 4 \\
\hline 4.7) Diminuiu os estoques de matéria-prima. & 0 & 1 & 2 & 3 & \\
\hline 4.8) Diminuiu os estoques de material em processo. & 0 & 1 & 2 & 3 & \\
\hline 4.9) Diminuiu os estoques de produto acabado. & 0 & 1 & 2 & 3 & \\
\hline $\begin{array}{l}\text { 4.10) Conseguiu reduzir a área de produção, por causa de rearranjos no layout do chão de } \\
\text { fábrica. }\end{array}$ & 0 & 1 & 2 & 3 & \\
\hline 4.11) Conseguiu reduzir a movimentação de material e pessoas. & 0 & 1 & 2 & 3 & \\
\hline 4.12) Conseguiu aumentar sua participação no mercado consumidor. & 0 & 1 & 2 & & 4 \\
\hline 4.13) Percebeu mudanças culturais em seus funcionários e no ambiente de trabalho. & 0 & 1 & 2 & & 4 \\
\hline 4.14) Influenciou significativamente a política de vendas/marketing. & 0 & 1 & 2 & 3 & \\
\hline 4.15) Mudou a política de desenvolvimento do produto. & 0 & 1 & 2 & 3 & \\
\hline 4.16) Aumentou a qualidade de seus produtos. & 0 & 1 & 2 & 3 & \\
\hline 4.17) Aumentou o mix de produtos. & D & 1 & 2 & 3 & \\
\hline 4.18) Conseguiu influenciar seus fornecedores quanto à forma de entrega de material. & 0 & 1 & 2 & 3 & \\
\hline 4.19) Aumentou o número de fornecedores. & 0 & 1 & 2 & T & 4 \\
\hline 4.20) Diminuiu o número de fornecedores. & 0 & 1 & D & 3 & 4 \\
\hline 4.21) Alterou seu fluxo de informações. & 0 & 1 & 2 & 3 & \\
\hline
\end{tabular}




\section{Comentários finais.}

\section{1) A empresa continua utilizando a Produção Enxuta?}

Sim. A empresa quer estendem para outras famílias de produtos.

5.2) A empresa atribui os resultados positivos obtidos somente à implementação da Produção Enxuta? Comente.

Sim.

5.3) Quais outras vantagens encontradas na Produção Enxuta ainda não abordadas neste roteiro de entrevista?

O pessoal fica mais calmo, porque eles confiam no sistema. Hoje, o supermercado de peças de montagem ajuda a fazer a cura da pintura melhor, as máquinas antes eram montadas as pressas. As informações são mais confiáveis. O sistema Lean traz tranquiilidade, qualidade, eficiência e atendimento.

5.4) Quais outras desvantagens encontradas na Produção Enxuta ainda não abordadas neste roteiro de entrevista?

Não.

5.5) Faça um comentário sobre um aspecto relacionado a esse assunto e que, possivelmente, não foi abordado (Se sentir necessidade).

O sistema Lean agrega valor, informações e trabalho tranqüilo. O sistema Lean trouxe bastante tranqüilidade para empresa e clientes.

Obrigada pela sua colaboração! 


\section{APÊNDICE H - ROTEIRO DE ENTREVISTA DA EMPRESA H}

\section{Roteiro de entrevista}

Data: $10 / 05 / 2005$

Nome da empresa: Empresa $\mathrm{H}$

Ramo de atividade: Implementos Agrícolas

Produtos: Ceifadores, Transferidores de linha, Carretas Graneleiras e Recolhedoras

Faturamento: aproximadamente 60 milhões de reais anuais

Principais clientes: A maior parte das vendas é feita através de revendas. A exportação é feita através do grupo da qual a empresa faz parte, vendendo para os Estados Unidos. Hoje a empresa está entrando no mercado da África e Europa.

Principais concorrentes: outra empresa (recolhedora), a principal ameaça seriam as máquinas automotrizes.

Número de funcionários: 174 funcionários

Entrevistado: Fernando Yassuo Hirae

Cargo: consultor do projeto

\section{Histórico}

1.1) Quando e por que a empresa começou a utilizar a Produção Enxuta?

A empresa começou o projeto em novembro de 2003, porque a demanda era alta, mas a empresa tinha: altos estoques; baixa produtividade; excesso de horas extras, gerando um alto custo de manufatura. Por essas razões, a empresa decidiu implementar a Produção Enxuta, para atacar esses desperdícios e não sofrer tanto quando a demanda estiver 
baixa. A empresa optou pelo sistema Lean, porque já conhecia o trabalho feito na empresa D e participaram de uma palestra da consultoria.

A empresa achou que o sistema Lean poderia atender as suas necessidades.

1.2) Qual sua participação no mercado consumidor naquele momento?

A atuação no mercado para a cultura do Amendoim é de $100 \%$ e para a cultura de Feijão é de $80 \%$.

1.3) Os fatores motivadores para a mudança foram internos ou externos? Quais foram? Explique.

Fatores internos: os problemas existentes na época da implementação. Fator externo: O aprendizado fornecido pela empresa D serviu como fator motivador para a mudança.

1.4) Qual(is) foi(ram) o(s) principal(is) agente(s) de mudança?

O presidente do grupo apostou na idéia e um vice-diretor industrial foi quem ficou responsável pelo projeto. Quando ele saiu da empresa, a equipe do Projeto Lean assumiu essa responsabilidade.

1.5) Houve ajuda de terceiros, como consultoria?

( X ) Sim. Como a empresa entrou em contato? Através da empresa D. Qual a razão da escolha? Por causa da indicação da empresa D.

( ) Não. Como se deu a mudança internamente? Qual(is) o(s) método(s) utilizado(s)?

\section{Desenvolvimento e Implementação}

2.1) Qual a estratégia de implementação adotada?

( ) Implementação Piloto

( ) Implementação Programática

( x ) Implementação Prototipal

Em todas as famílias, porém a ênfase maior está na família de máquinas recolhedoras. A empresa optou por fazer uma implementação mais consistente e longa, por visar uma mudança na cultura organizacional.

2.2) Qual(is) foi(ram) a(s) principal(is) medida(s) tomada(s) quando começou a implementação da Produção Enxuta?

Formação de uma equipe com funcionários da média e alta gerencia, atuando conjuntamente com a consultoria.

Treinamento dessa equipe.

Primeira implementação do projeto

Treinamento de todos os funcionários

Implementação do projeto.

2.3) Quais e quantos funcionários foram envolvidos na implementação? 
$\mathrm{Na}$ equipe tinham 12 pessoas da empresa das diversas áreas. Os cargos ocupados por elas são de líderes, supervisores e o pessoal do administrativo.

2.4) Quais foram os principais problemas encontrados no projeto e na implementação?

No início do projeto a demanda era alta e com isso o pessoal não tinha tempo suficiente para se dedicar ao projeto.

A falta de treinamento do pessoal do chão de fábrica também atrapalhou porque o projeto não conseguia dar continuidade as melhorias.

A resistência dos funcionários em aceitarem as idéias novas também foi uma dificuldade encontrada.

2.5) Qual o investimento estimado na implementação da Produção Enxuta?

A empresa investiu em consultoria, cerca de 70 mil reais anuais. Outros gastos como fabricação de carrinhos, pallets, etc., foram inexpressivos para a empresa.

2.6) O sistema de custeio dos produtos e do gerenciamento dos custos da empresa foi afetado pelo projeto de Produção Enxuta?

A empresa possui um sistema de custeio, mas o projeto está modificando esse sistema.

O projeto estará propondo algumas mudanças para atender um modelo de custeio lean.

2.7) Após a implementação da Produção Enxuta, a empresa precisou modificar sua medida de desempenho de produção de máquinas/ operador?

A empresa não possuía esta medida. A partir do sistema de custeio que será implementado ela terá os dados para esta medida.

2.8) A empresa utilizava algum sistema de medição de desempenho para setup? Após a implementação da Produção Enxuta este sistema foi alterado?

A empresa não possui. Mas tem uma proposta de medição do setup para ser implementada.

2.9) Qual era o takt time da operação antes da implementação da Produção Enxuta e qual é o atual?

O takt time foi medido através das recolhedoras, que teve seu produto modificado. Antes da implementação era de 5 máquinas/ dia. Hoje o takt time é de 3 máquinas/ dia, porque o produto sofreu alterações e a demanda diminuiu. 
(A partir deste ponto o roteiro de entrevista irá apresentar algumas perguntas referentes às práticas da Produção Enxuta, com alternativas, por favor assinale aquela que mais se adequar a sua empresa)

\section{3) Práticas}

3.1)Quanto a utilização dos 5S, pode-se afirmar que trouxe impactos significativos para a empresa quanto a melhoria no ambiente de trabalho.

3.2) O 5S serviu de elemento inicial para a implementação base para a disseminação dos conceitos da Produção Enxuta na empresa.

3.3) A padronização do trabalho contribuiu para melhor utilização dos recursos da empresa.

3.4) A padronização do trabalho foi implementada extensivamente na empresa.

3.5) A utilização do Layout celular trouxe grandes mudanças no chão de fábrica quanto a disposição das máquinas e equipamentos.

3.6) O Layout celular foi utilizado extensivamente na empresa.

3.7) A utilização do Kanban trouxe agilidade nos processos produtivos quanto à necessidade de material ou de informações.

3.8) O Kanban foi utilizado extensivamente na empresa.

3.9) A utilização do Heijunka box ou o nivelamento de produção trouxe maior flexibilização e precisão na produção através de ajustes e reprogramação dos operadores.

3.10) Com a utilização do Mapa do Fluxo de Valor conseguiu-se visualizar e entender melhor todos os processos produtivos da empresa.

3.11) Com a utilização do Mapa do Fluxo de Valor, a empresa conseguiu tomar as melhores decisões e seguir um plano de ações estruturadas.

3.12) A utilização da Manutenção Produtiva Total trouxe diminuição nas paradas imprevistas de máquinas, facilitando atingir as metas de produção.

3.13) Com a utilização da Administração da Qualidade Total, os funcionários criaram um senso de responsabilidade e autoridade quanto à produção.

3.14) A Administração da Qualidade Total trouxe para a empresa redução nos custos da qualidade.

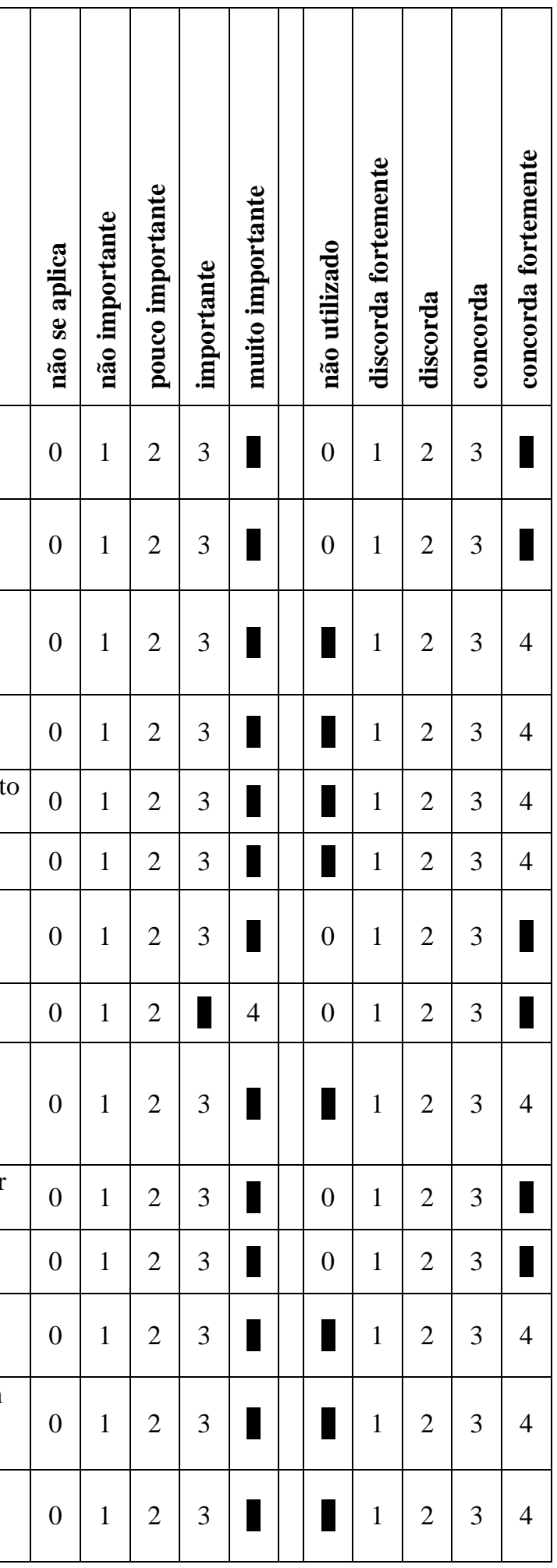




\section{Os Resultados Obtidos}

(Na tabela abaixo, assinale a alternativa que melhor exprima a realidade da empresa)

\begin{tabular}{|c|c|c|c|c|c|}
\hline $\begin{array}{l}\text { Quanto aos resultados obtidos devido ao uso da Produção Enxuta, a } \\
\text { empresa: }\end{array}$ & 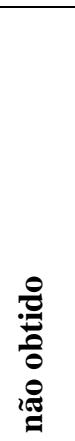 & 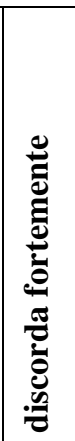 & 苞 & 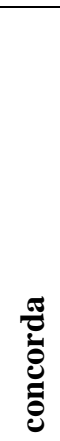 & 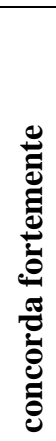 \\
\hline 4.1) Conseguiu melhorar sua produtividade em relação à produção/recursos/tempo. & 0 & 1 & 2 & 3 & \\
\hline $\begin{array}{l}\text { 4.2) Conseguiu melhorar o atendimento no prazo do pedido de seus clientes, ou seja, melhorou a } \\
\text { pontualidade de entrega. }\end{array}$ & 0 & 1 & 2 & 3 & \\
\hline 4.3) Conseguiu reduzir o lead time de fabricação. & 0 & 1 & 2 & 3 & \\
\hline 4.4) Conseguiu reduzir os custos de fabricação. & 1 & 1 & 2 & 3 & 4 \\
\hline 4.5) Aumentou o faturamento. & 0 & 1 & ] & 3 & 4 \\
\hline 4.6) Aumentou a lucratividade. & T & 1 & 2 & 3 & 4 \\
\hline 4.7) Diminuiu os estoques de matéria-prima. & 0 & 1 & 2 & 3 & \\
\hline 4.8) Diminuiu os estoques de material em processo. & 0 & 1 & 2 & 3 & \\
\hline 4.9) Diminuiu os estoques de produto acabado. & T & 1 & 2 & 3 & 4 \\
\hline $\begin{array}{l}\text { 4.10) Conseguiu reduzir a área de produção, por causa de rearranjos no layout do chão de } \\
\text { fábrica. }\end{array}$ & 0 & 1 & 2 & 3 & \\
\hline 4.11) Conseguiu reduzir a movimentação de material e pessoas. & 0 & 1 & 2 & 3 & \\
\hline 4.12) Conseguiu aumentar sua participação no mercado consumidor. & 1 & 1 & 2 & 3 & 4 \\
\hline 4.13) Percebeu mudanças culturais em seus funcionários e no ambiente de trabalho. & 0 & 1 & 2 & 3 & \\
\hline 4.14) Influenciou significativamente a política de vendas/marketing. & D. & 1 & 2 & 3 & 4 \\
\hline 4.15) Mudou a política de desenvolvimento do produto. & 1 & 1 & 2 & 3 & 4 \\
\hline 4.16) Aumentou a qualidade de seus produtos. & 0 & 1 & 2 & 3 & \\
\hline 4.17) Aumentou o mix de produtos. & 0 & 1 & 2 & & 4 \\
\hline 4.18) Conseguiu influenciar seus fornecedores quanto à forma de entrega de material. & 0 & 1 & 2 & & 4 \\
\hline 4.19) Aumentou o número de fornecedores. & 0 & 1 & & 3 & 4 \\
\hline 4.20) Diminuiu o número de fornecedores. & 0 & 1 & 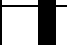 & 3 & 4 \\
\hline 4.21) Alterou seu fluxo de informações. & 0 & 1 & 2 & 3 & \\
\hline
\end{tabular}




\section{Comentários finais.}

\section{1) A empresa continua utilizando a Produção Enxuta?}

Sim. A empresa tem planos de dar continuidade ao projeto.

5.2) A empresa atribui os resultados positivos obtidos somente à implementação da Produção Enxuta? Comente.

Sim. A empresa já tinha feito outras tentativas de melhorar seu sistema produtivo anteriormente utilizando outras metodologias, mas não foi bem sucedida.

5.3) Quais outras vantagens encontradas na Produção Enxuta ainda não abordadas neste roteiro de entrevista?

A mudança comportamental é o grande ganho deste sistema.

5.4) Quais outras desvantagens encontradas na Produção Enxuta ainda não abordadas neste roteiro de entrevista?

Não.

5.5) Faça um comentário sobre um aspecto relacionado a esse assunto e que, possivelmente, não foi abordado (Se sentir necessidade).

O projeto poderia ter um andamento mais rápido, mas como ele exige uma mudança comportamental torna-se mais lenta sua implementação.

Obrigada pela sua colaboração! 


\section{APÊNDICE I - ROTEIRO DE ENTREVISTA DA EMPRESA I}

\section{Roteiro de entrevista}

Data: $20 / 04 / 2005$

Nome da empresa: Empresa I

Ramo de atividade: Máquinas e Implementos agrícolas

Produtos: Linha de Pulverizadores:

- Acoplados, máquinas que vão acopladas no trator;

- Arrasto, puxados pelo trator;

- Turbina, chamados atomizadores e canhões; e

- Autopropelido, máquinas com motor: mecânica e hidráulica

Faturamento: 170 milhões de reais em 2004

Principais clientes: As vendas são feitas através de revendas ou diretamente com a área comercial, depende do tipo de produto. Em algumas linhas tem distribuidores, principalmente da região sul. No centro este, a venda é direta. Para a exportação, a empresa atua através de revendas, atendendo a América do Sul, América Central e EUA. Na Argentina, a empresa tem uma filial própria. A empresa está começando as vender para a África do Sul.

Principais concorrentes: Empresas D e F e outras

Número de funcionários: aproximadamente 300 funcionários

Entrevistado: Aguida de Araújo Carvalho Luz

Cargo: Gerente de Produção/ Gerente do Projeto Lean

\section{Histórico}

1.1) Quando e por que a empresa começou a utilizar a Produção Enxuta? 
No CSMIA em 2002, a empresa D apresentou seus resultados e convidou os interessados a conhecerem a empresa, foi dessa forma que a empresa tomou conhecimento do sistema Lean. A partir deste momento, a empresa comprou dois livros: Mentalidade Enxuta (Womack e Jones) e Aprendendo a Enxergar (Rother e Shook), e depois foram no Lean Summit em Gramado-RS, em 2002.

A empresa tinha um bom produto (pulverizador autopropelido), e tinha demanda, mas não tinham dinheiro para investir em barracão, maquinário, mão-de-obra, para fazer a quantidade que o mercado demandava. Foi montado um grupo de 11 pessoas de estudos, e fizeram o primeiro mapa do fluxo de valor.

Em maio de 2003, a empresa escolheu a família dos pulverizadores autopropelidos para o projeto. De 2002 para 2003, a produção triplicou e 2003 e 2004, mais que duplicaram. De saldo 2002/2004, deu 4,6 de aumento. Com 40\% apenas de aumento em mão-deobra, e em equipamentos, a empresa não precisou investir.

1.2) Qual sua participação no mercado consumidor naquele momento?

O produto era novo e o mercado estava todo direcionado para a empresa. A concorrência tinha, mas era um produto importado com um preço maior e com peças de reposição caras.

1.3) Os fatores motivadores para a mudança foram internos ou externos? Quais foram? Explique.

Fator Externo: demanda alta.

Fator Interno: a necessidade de atender este mercado. Era um desafio colocar o produto na quantidade exigida no mercado.

1.4) Qual(is) foi(ram) o(s) principal(is) agente(s) de mudança?

A sócia-proprietária e a gerente de produção. Hoje já existem diversos agentes de mudanças distribuídos nas áreas da empresa.

1.5) Houve ajuda de terceiros, como consultoria?

( $\mathrm{x}$ ) Sim. Como a empresa entrou em contato? Foram no Lean Summit e entraram em contato. Qual a razão da escolha? A empresa não queria uma consultoria, e o Lean Institute atua como apoiador do projeto, vindo quando solicitados na empresa.

( ) Não. Como se deu a mudança internamente? Qual(is) o(s) método(s) utilizado(s)?

\section{Desenvolvimento e Implementação}

2.1) Qual a estratégia de implementação adotada?

( x ) Implementação Piloto

( ) Implementação Programática

( ) Implementação Prototipal

Família de Pulverizadores Autopropelidos, escolhida por causa da alta demanda.

2.2) Qual(is) foi(ram) a(s) principal(is) medida(s) tomada(s) quando começou a implementação da Produção Enxuta? 
Formou-se um grupo com pessoas das áreas da engenharia, da qualidade, de suprimentos, da produção, do comercial e financeiro.

Treinamento para a equipe com o Lean Institute (2 dias)

Implementação: Mapeamento do Fluxo de Valor e Criação de Fluxo

Este grupo foi divido em três, para atacarem os diferentes problemas identificados.

2.3) Quais e quantos funcionários foram envolvidos na implementação?

O grupo era composto de 11 funcionários, não dedicados ao projeto.

2.4) Quais foram os principais problemas encontrados no projeto e na implementação?

Em 2003, o projeto não envolveu o pessoal de chão de fábrica, que atribuíam todo o sucesso no pessoal no grupo, eles não se sentiam envolvidos.

Em 2004, o grupo do projeto criou a função de apoiador (team líder), que formaram um elo entre as partes.

Hoje, tendo participado de outros workshops no Lean Summit, a empresa está começando a trabalhar com o trabalho padronizado.

2.5) Qual o investimento estimado na implementação da Produção Enxuta?

Os investimentos foram, apenas, com a compra de livros, viagem ao Lean Summit e com o apoio do Lean Institute. Aproximadamente R \$ 100.000,00.

2.6) O sistema de custeio dos produtos e do gerenciamento dos custos da empresa foi afetado pelo projeto de Produção Enxuta?

Não existia. E ainda não está claro o quanto a empresa conseguiu reduzir. O pessoal do financeiro não conseguiu acompanhar o projeto. Eles estão buscando os indicadores neste ano.

2.7) Após a implementação da Produção Enxuta, a empresa precisou modificar sua medida de desempenho de produção de máquinas/ operador?

A empresa possui um indicador chamado Máquina equivalente por homem. Antes do projeto em 2002 era de 1,95 por homem, hoje este índice está em 12 por homem.

2.8) A empresa utilizava algum sistema de medição de desempenho para setup? Após a implementação da Produção Enxuta este sistema foi alterado?

Praticamente não tem setup na linha piloto, porque o processo é manual e feito em fluxo, considerando os processos de solda, pintura e montagem. Na metalurgia, que é um processo compartilhado com outros produtos, o projeto ainda não trabalhou. Lá será feito um trabalho de setup.

2.9) Qual era o takt time da operação antes da implementação da Produção Enxuta e qual é o atual?

Em 2002 era 1 máquina por semana.

Em 2003, 1 máquina por dia. Em 2004, 3 máquinas por dia. 
(A partir deste ponto o roteiro de entrevista irá apresentar algumas perguntas referentes às práticas da Produção Enxuta, com alternativas, por favor assinale aquela que mais se adequar a sua empresa)

\section{3) Práticas}

3.1)Quanto a utilização dos 5S, pode-se afirmar que trouxe impactos significativos para a empresa quanto a melhoria no ambiente de trabalho.

3.2) O 5S serviu de elemento inicial para a implementação base para a disseminação dos conceitos da Produção Enxuta na empresa.

3.3) A padronização do trabalho contribuiu para melhor utilização dos recursos da empresa.

3.4) A padronização do trabalho foi implementada extensivamente na empresa.

3.5) A utilização do Layout celular trouxe grandes mudanças no chão de fábrica quanto a disposição das máquinas e equipamentos.

3.6) O Layout celular foi utilizado extensivamente na empresa.

3.7) A utilização do Kanban trouxe agilidade nos processos produtivos quanto à necessidade de material ou de informações.

3.8) O Kanban foi utilizado extensivamente na empresa.

3.9) A utilização do Heijunka box ou o nivelamento de produção trouxe maior flexibilização e precisão na produção através de ajustes e reprogramação dos operadores.

3.10) Com a utilização do Mapa do Fluxo de Valor conseguiu-se visualizar e entender melhor todos os processos produtivos da empresa.

3.11) Com a utilização do Mapa do Fluxo de Valor, a empresa conseguiu tomar as melhores decisões e seguir um plano de ações estruturadas.

3.12) A utilização da Manutenção Produtiva Total trouxe diminuição nas paradas imprevistas de máquinas, facilitando atingir as metas de produção.

3.13) Com a utilização da Administração da Qualidade Total, os funcionários criaram um senso de responsabilidade e autoridade quanto à produção.

3.14) A Administração da Qualidade Total trouxe para a empresa redução nos custos da qualidade.

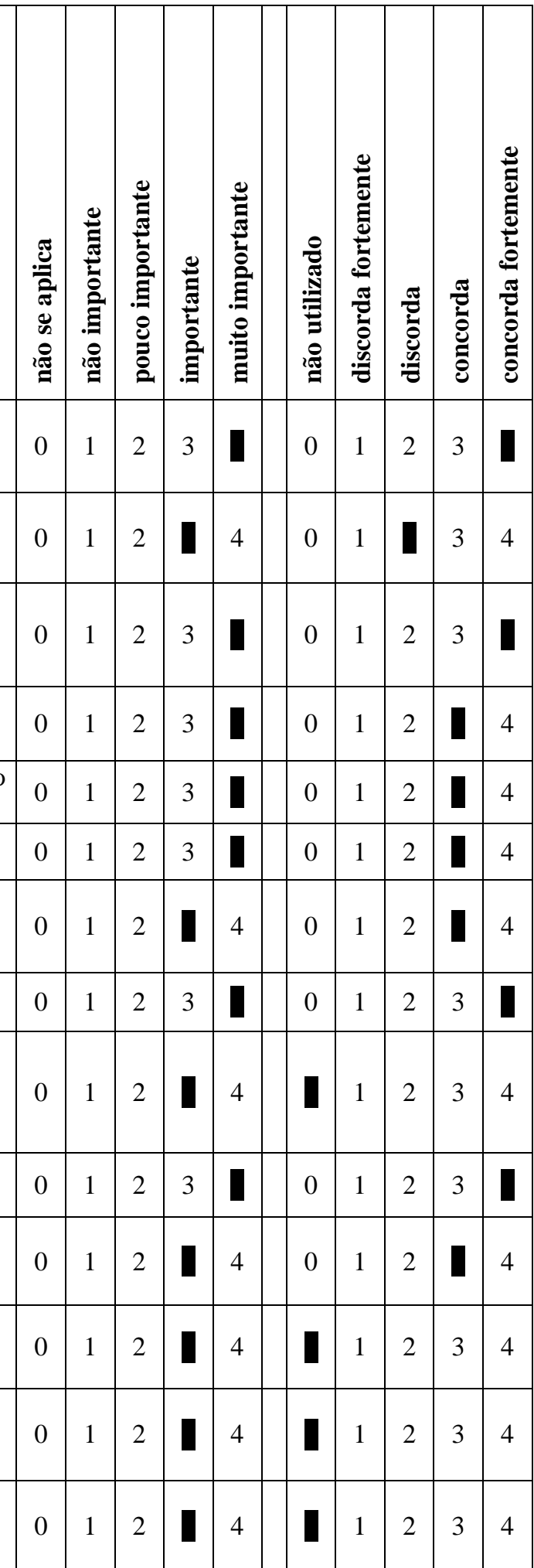




\section{Os Resultados Obtidos}

(Na tabela abaixo, assinale a alternativa que melhor exprima a realidade da empresa)

\begin{tabular}{|c|c|c|c|c|c|}
\hline $\begin{array}{l}\text { Quanto aos resultados obtidos devido ao uso da Produção Enxuta, a } \\
\text { empresa: }\end{array}$ & 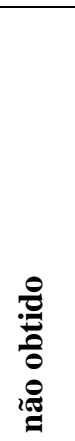 & 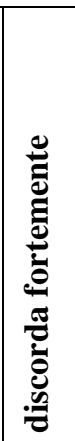 & 苞 & 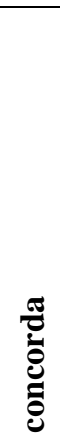 & 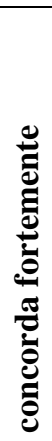 \\
\hline 4.1) Conseguiu melhorar sua produtividade em relação à produção/recursos/tempo. & 0 & 1 & 2 & 3 & \\
\hline $\begin{array}{l}\text { 4.2) Conseguiu melhorar o atendimento no prazo do pedido de seus clientes, ou seja, melhorou a } \\
\text { pontualidade de entrega. }\end{array}$ & 0 & 1 & 2 & 3 & \\
\hline 4.3) Conseguiu reduzir o lead time de fabricação. & 0 & 1 & 2 & 3 & \\
\hline 4.4) Conseguiu reduzir os custos de fabricação. & T & 1 & 2 & 3 & 4 \\
\hline 4.5) Aumentou o faturamento. & 0 & 1 & 2 & 3 & \\
\hline 4.6) Aumentou a lucratividade. & 0 & 1 & 2 & 3 & \\
\hline 4.7) Diminuiu os estoques de matéria-prima. & T & 1 & 2 & 3 & \\
\hline 4.8) Diminuiu os estoques de material em processo. & 0 & 1 & 2 & 3 & \\
\hline 4.9) Diminuiu os estoques de produto acabado. & T & 1 & 2 & 3 & 4 \\
\hline $\begin{array}{l}\text { 4.10) Conseguiu reduzir a área de produção, por causa de rearranjos no layout do chão de } \\
\text { fábrica. }\end{array}$ & 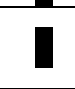 & 1 & 2 & 3 & 4 \\
\hline 4.11) Conseguiu reduzir a movimentação de material e pessoas. & 0 & 1 & 2 & 3 & \\
\hline 4.12) Conseguiu aumentar sua participação no mercado consumidor. & 0 & 1 & 2 & 3 & \\
\hline 4.13) Percebeu mudanças culturais em seus funcionários e no ambiente de trabalho. & 0 & 1 & 2 & 3 & \\
\hline 4.14) Influenciou significativamente a política de vendas/marketing. & 0 & 1 & 2 & 1 & 4 \\
\hline 4.15) Mudou a política de desenvolvimento do produto. & D & 1 & 2 & 3 & 4 \\
\hline 4.16) Aumentou a qualidade de seus produtos. & 0 & 1 & 2 & T & 4 \\
\hline 4.17) Aumentou o mix de produtos. & 0 & 1 & 2 & 3 & \\
\hline 4.18) Conseguiu influenciar seus fornecedores quanto à forma de entrega de material. & 0 & 1 & 2 & 1 & 4 \\
\hline 4.19) Aumentou o número de fornecedores. & 0 & 1 & T & 3 & 4 \\
\hline 4.20) Diminuiu o número de fornecedores. & T & 1 & 2 & 3 & 4 \\
\hline 4.21) Alterou seu fluxo de informações. & 0 & 1 & 2 & & 4 \\
\hline
\end{tabular}




\section{Comentários finais.}

\section{1) A empresa continua utilizando a Produção Enxuta?}

Sim, com projetos futuros para outras famílias.

5.2) A empresa atribui os resultados positivos obtidos somente à implementação da Produção Enxuta? Comente.

A filosofia da Produção Enxuta foi responsável pelos resultados obtidos.

5.3) Quais outras vantagens encontradas na Produção Enxuta ainda não abordadas neste roteiro de entrevista?

O fator motivacional. O trabalho em equipe ficou claro e consolidado na empresa, causando um fator motivacional, a valorização do ser humano.

5.4) Quais outras desvantagens encontradas na Produção Enxuta ainda não abordadas neste roteiro de entrevista?

Não. A empresa errou em alguns caminhos. Requer adaptar a filosofia a realidade da empresa, e não querer fazer tudo que Taichi Ohno fez.

5.5) Faça um comentário sobre um aspecto relacionado a esse assunto e que, possivelmente, não foi abordado (Se sentir necessidade).

O crescimento é geral nas empresas e nas pessoas com essa filosofia, e é preciso levar isto para o país. As pessoas têm que querem fazer e colocar a mão na massa, participar. A empresa $D$ foi muito generosa, quando mostrou sua fábrica. A função da ABIMAQ é fortalecer as empresas brasileiras. A divulgação é essencial.

Obrigada pela sua colaboração! 